UNIVERSITAS 



\section{UNIVERSITAS}

REVISTA DE CIENCIAS SOCIALES Y HUMANAS

Año XV, Número 27 / septiembre 2017-marzo 2018

ISSN impreso: 1390-3837 / ISSN electrónico: 1390-8634

Universitas está indexada en las siguientes

Bases de Datos y sistemas de información científica:

BASE DE DATOS INTERNACIONALES SELECTIVAS
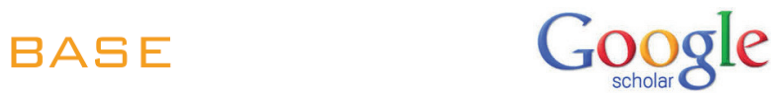

PLATAFORMAS DE EVALUACIÓN DE REVISTAS

\section{MIAR}

DIRECTORIOS SELECTIVOS
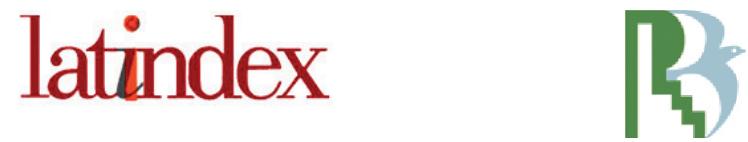

HEMEROTECAS SELECTIVAS

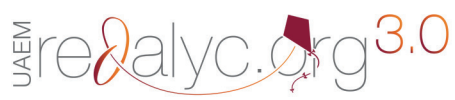

BUSCADORES DE LITERATURA CIENTÍFICA OPEN ACCESS
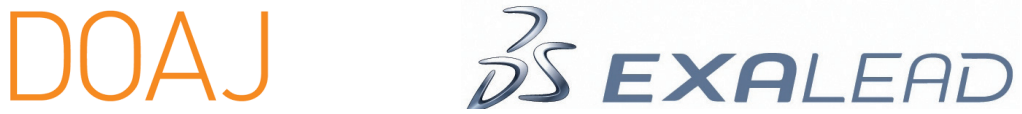

POLÍTICAS DE COPYRIGHT DE LAS EDITORIALES Y AUTOARCHIVO 


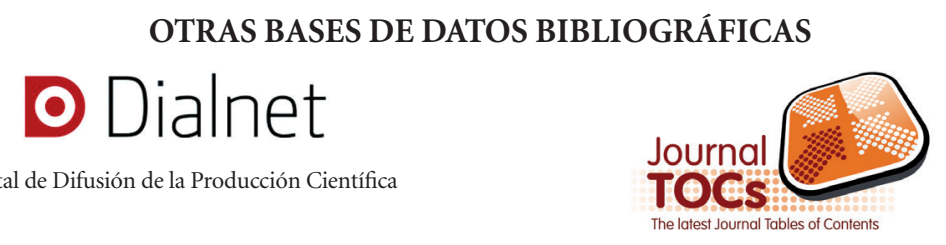

CATÁLOGO DE BIBLIOTECAS INTERNACIONALES

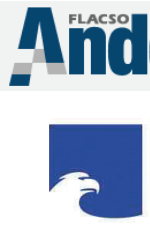

- Biblioteca Digital de Vanguardia para la Investigación en Ciencias Sociales REGIÓN ANDINA Y AMÉRICA LATINA

Ibero-Amerikanisches

Institut

Preußischer Kulturbesitz
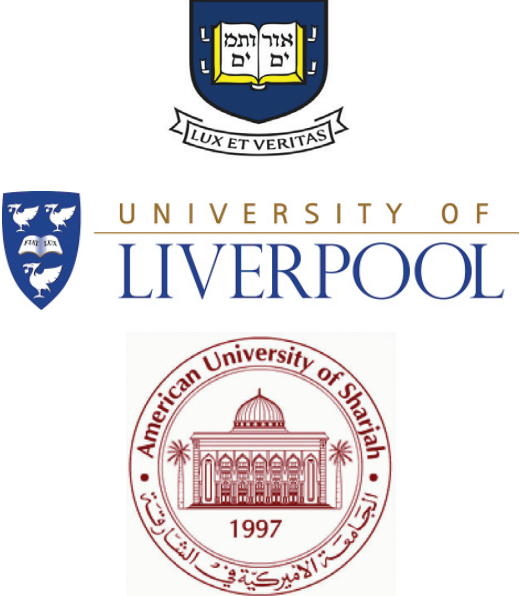

Hanzehogeschool Groningen
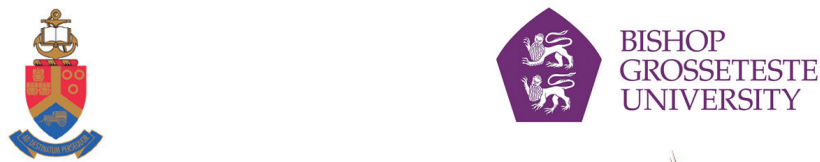

UNIVERSITEIT VAN PRETORIA UNIVERSITY OF PRETORIA

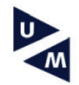

Maastricht University
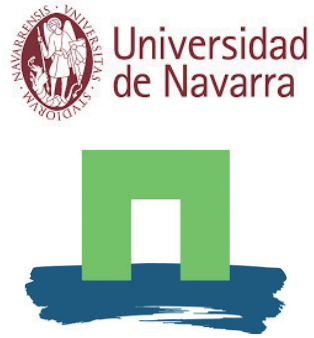

Wageningen University
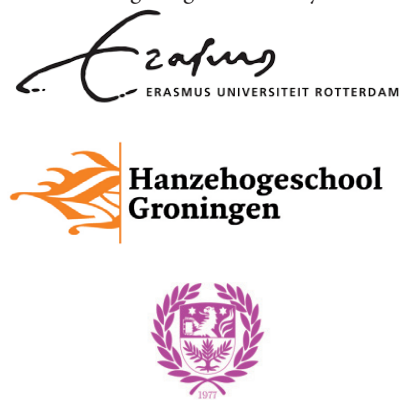

UNIVERSITY

OF SKÖVDE

UROSSETESTE

Sainte Anne

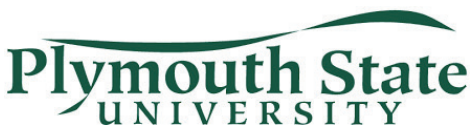




\section{$\frac{\text { MUHLENBERG }}{\text { COLLEGE }}$}

FRANLIN\&MARSHALL

6. TYNIDALE

5

The University of NORTH CAROLINA

GREENSBORO

Virginia

[II!] Tech

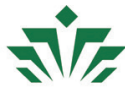

UNC CHARLOTTE

ED DePaul University

\section{Nebraska \\ Omaha}

Southwestern University

SAN ANTONIO

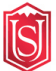

SIMPSON

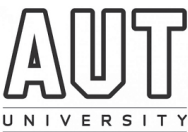

世约

CLAREMONT MCKENNA MCKENNA

UNIVERSITY

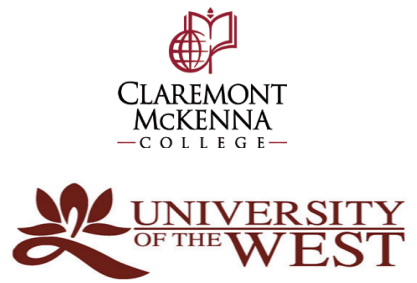

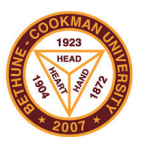

REVISTA CONSORCIADA

Comunicicar 
Universitas-UPS, Revista de Ciencias Sociales y Humanas de la Universidad Politécnica Salesiana del Ecuador, que se inicia en el año 2002, tiene una regularidad semestral.

El objetivo de Universitas-UPS es promover y difundir la publicación de textos científicos y críticos, inéditos y previamente evaluados, de carácter e interés actuales, en el campo de los conocimientos de lo social y humano y sobre problemáticas de alcance general, aunque privilegiando aquellos referidos en particular al Ecuador y América Latina.

La Revista presenta artículos y ensayos, investigaciones en curso o resultados de ellas, análisis y comunicaciones de perfil más coyuntural, y reseñas o recensiones de libros.

http://www.ups.edu.ec

Correo electrónico: revistauniversitas@ups.edu.ec

Rector

Javier Herrán Gómez, sdb

Vicerrector General Académico

Luis Tobar Pesántez

Vicerrector Docente

Fernando Pesántez Avilés

Vicerrector de Investigación

Juan Pablo Salgado Guerrero

Vicerrectores de sede

César Vásquez Vásquez (Cuenca)

José Juncosa Blasco (Quito)

Andrés Bayolo Garay (Guayaquil)

Universitas-UPS, Revista de Ciencias Sociales y Humanas, publicación semestral, No. 27, juliodiciembre de 2017. Editor responsable: René Unda Lara. ISSN impreso: 1390-3837 / ISSN electrónico: 1390-8634. Diseño y corrección: Editorial Universitaria Abya-Yala. Domicilio de la publicación: Universidad Politécnica Salesiana del Ecuador. Casilla postal 2074, CuencaEcuador. Centro Gráfico Salesiano: Vega Muñoz 10-68 y General Torres, Teléfono (+593 7) 2831745, Casilla 01-01-0275, Cuenca-Ecuador.

D.R. (c) Universitas. Revista de Ciencias Sociales y Humanas.

Impreso en Ecuador

UNIVERSITAS es una publicación semestral de la Universidad Politécnica Salesiana del Ecuador. Las ideas y opiniones expresadas en las colaboraciones son de exclusiva responsabilidad de los autores. 


\section{Consejo de Editores (Editors Board)}

\section{Editora (Editor)}

Dra. Amor Pérez Rodríguez, Universidad de Huelva, España

\section{Editores Adjuntos (Assistant Editors)}

Dr. René Unda Lara, Universidad Politécnica Salesiana, Ecuador

Dr.(c) Saúl Uribe Taborda, Universidad Politécnica Salesiana, Ecuador

\section{Consejo Científico (Advisory Board)}

Dr. Alberto Acosta, FLACSO, Ecuador

Dr. Oscar Aguilera Ruiz, U. de Chile, Chile

Dra. Sara Victoria Alvarado, CINDE Universidad de Manizales, Colombia

Dr. Eduard Arriaga, Universidad de Western Ontario, Canadá

Dr. Jorge Baeza, U. Católica Silva Henríquez, Chile

Dr. Jorge Benedicto, UNED, España

Dra. Silvia Borelli, Pontificia Universidad Católica de Sao Paulo, Brasil

Dr. Luis Bruzón Delgado, Fundación DEMUCA (AECID), Costa Rica

Dra. Alida Carloni, Universidad de Huelva, España

Dra. Rita María Cassia de Oliveira, PUCSP, Brasil

Dr. José Rubén Castillo, U. Autónoma de Manizales, Colombia

Dr. Manuel Cebrián de la Serna, Universidad de Málaga, España

Dr. René Ceballos, Universidad Católica Boliviana. La Paz, Bolivia

Dra. Ma. Isabel Domínguez, Centro Investigaciones Psicológicas y Sociológicas, Cuba

Dr. Carles Feixa, Universidad de Lleida, España

Dra. Bertha García, Pontificia Universidad Católica del Ecuador

Dra. Claudia García Muñoz, U. Pereira, Colombia

Dr. David González Cruz, Universidad de Huelva, España

Dr. Rafael Grasa, Universidad Autónoma de Barcelona, España

Dr. José Luis Guzón, Universidad Pontificia de Salamanca, España

Dr. Antonio Hermosa, Universidad de Sevilla, España

Dr. François Houtart, Universidad de Lovaina, Bélgica (+)

Dr. Xavier Izko, Universidad Politécnica Salesiana, Ecuador

Dr. Manfred Liebel, Universidad de Berlín, Alemania

Dr. Jesús Leal, Universidad Complutense de Madrid, España

Dr. Fernando López Noguero, Universidad Pablo de Olavide, España

Dra. Valeria Llobet, Universidad Nacional San Martín, Argentina

Dr. Fernando Mayorga, Universidad Mayor de San Simón, Bolivia

Dr. Julio Mejía, Universidad Nacional Mayor de San Marcos, Perú

Dr. Ángel Montes, Universidad de Murcia, España

Dr. Germán Muñoz, U. Distrital Fco. José de Caldas, Colombia 
Dra. María Elena Ortiz, Universidad Politécnica Salesiana, Ecuador

Dr. Lucas Pacheco, Pontificia Universidad Católica del Ecuador

Dr. Franklin Ramírez, FLACSO Ecuador

Dr. Juan Romero, Universidad de La República, Uruguay

Dr. Florencia Juana Saintout, Universidad Nacional de La Plata, Argentina

Dr. Giampietro Schibotto, Universidad de Bologna, Italia

Dr. José Manuel Valenzuela, Colegio de la Frontera Norte, México

Dr. Manuel Ángel Vázquez Medel- Universidad de Sevilla, España

Dra. Melina Vázquez, Universidad de Buenos Aires, Argentina

Dr. Gaitán Villavicencio, Universidad de Guayaquil, Ecuador

Dr. Pablo Vommaro, Universidad de Buenos Aires, Argentina

Dra. Isabel Yépez, Universidad de Lovaina, Bélgica

\section{Consejo Internacional de Revisores (International Reviewers Board)}

Dra. Alexandra Agudelo, Universidad Autónoma Latinoamericana, Colombia

Dr. Emilio Álvarez Arregui, Universidad de Oviedo, España.

Dra. Catarina Alves Costa, Universidade Nova de Lisboa

Dra. Ana Paula Alves Ribeiro, Universidade do Estado do Rio de Janeiro

Dr. Xavier Andrade, Universidad de los Andes, Colombia

Dra. Karen Andrade Mendoza, Universidad Central del Ecuador

Dra. Elisenda Ardevol, Universidad Abierta de Cataluña, Barcelona

Dra. Inmaculada Berlanga, Unir, España

Dra. Patricia Bermúdez, FLACSO Ecuador

Dr. César Bernal, Universidad de Almeria, España

MSc. Carmen Borja, Universidad Pablo Olavide, España

Dr. Hugo Burgos, Universidad San Francisco de Quito, Ecuador

Dra. M. Carmen Caldeiro, Universidad Pública de Navarra, España

Dr. Roger Canals, École des Hautes Études en Sciences Sociales de París

Dr. Gastón Carreño, Centro de Estudios en Antropología Visual, Chile

Dra. Patricia de Casas Moreno, Universidad de Huelva, España

Dra. Ana Castro Zubizarreta, Universidad de Cantabria, España

Dr. Manuel Cebrián de la Serna, Universidad de Málaga, España

Dr. David Chávez, Universidad Central del Ecuador

Ddo. Hugo Chávez, Universidad Autónoma Metropolitana Unidad Iztapalapa, México

Dra. Paloma Contreras Pulido, Universidad de Huelva, España

Dra. Rocío Cruz Díaz, Universidad Pablo de Olavide, España

Dr. José M. Cuenca, Universidad de Huelva, España

Dra. Agueda Delgado Ponce, Universidad de Huelva, España

MSc. Holger Díaz, Universidad Politécnica Salesiana, Ecuador

Dr. Manuel Fandos, Unir, España

Dra. Monica Fantin, Universidade Federal de Santa Catarina, Brasil 
Dra. Soraya Ferreira Vieira, Universidade Federal de Juiz de Fora, Brasil Dr. Carlos Flores, Universidad Autónoma del Estado de Morelos, México Dra. Margarita García Candeira, Universidad de Huelva, España

Dr. Blas Garzón, Universidad Politécnica Salesiana, Ecuador Dr. Manuel González Mairena, Universidad Pablo de Olavide, España Dr. Sebastián Granda, Universidad Politécnica Salesiana, Ecuador Dr. Ricardo Green, Goldsmiths, University of London.

Dra. Anne Gustavsson, Universidad Nacional de San Martín, Argentina Dr. Lizardo Herrera, Universidad de Pittsburg, EEUU

Dra. Mónica Hinojosa Becerra, Universidad Nacional de Loja, Ecuador Dra. Débora Lanzeni, Universidad de Buenos Aires

Dr. Christian León, Universidad de Buenos Aires

Dr. Edizon León, UASB, Ecuador

Dra. Rosalba Mancinas Chávez, Universidad de Sevilla, España

Dr. Rafael Marfil Carmona, Universidad de Granada, España

Dr. Isidro Marín Gutiérrez, Universidad de Huelva, España

Dra. Carmen Marta Lazo, Universidad de Zaragoza, España

Dr. Jorge Eliécer Martínez, U. La Salle, Colombia

Dr. Javier Marzal Felici, Universitat Jaume I, Valencia, España

Dr. Pedro Núñez, FLACSO, Argentina

Dr. Xaquín Núñez, Universidade do Minho, Portugal

Dr. Miguel Ángel Ortiz Sobrino, Universidad Complutense, España

MSc. Franco Passarelli, FLACSO Ecuador

Dr. Francisco Pavón Rabasco, Universidad de Sevilla, España

Dra. Paz Guarderas, Universidad Politécnica Salesiana, Ecuador

Dra. Alicia Peñalva, Universidad Pública de Navarra, España

Dra. Sarah Pink, University of Kent

Dra. Armanda Pinto Matos, Universidade de Coimbra

Dra. Ma del Mar Ramírez Alvarado, Universidad de Sevilla, España

Dra. Antonia Ramírez García, Universidad de Córdoba, España

Dr. Jordi Grau Rebollo, Universidad Autónoma de Barcelona

Dra. Paula Renés Arellano, Universidad de Cantabria, España

Dra. Mariana Rivera, Escuela Nacional de Antropología e Historia, México

Dr. Juan Ignacio Robles, Universidad Autónoma de Madrid

Dr. Alejandro Rodríguez Martín, Universidad de Oviedo, España

Dra. M. Mar Rodríguez Rosell, Universidad Católica San Antonio, España

Dra. Sara Román García, Universidad de Cádiz, España

Dra. Charo Sádaba, Universidad de Navarra, España

Dra. Yamile Sandoval, Alfamed, Colombia

Dra. María Fernanda Soliz, UASB, Ecuador 
Dr. Santiago Tejedor Calvo, Universidad Autónoma de Barcelona, España

Dra. Simona Tirocchi, Università di Torino, Italia

Dr.Vitor Tomé, Universidade do Algarve, Portugal

MSc. Christian Troya, FLACSO, Ecuador

Dra. María Fernanda Troya, Escuela de Altos Estudios en Ciencias Sociales, Paris

Dr. Ulises Unda, Universidad de Western Ontario University, Canadá

MSc. Diego Yela, FLACSO, Ecuador

Dra. Gabriela Zamorano, El Colegio de Michoacán, México

Dr. Antonio Zirión, Universidad Autónoma Metropolitana Unidad Iztapalapa, México

\section{Revisores científicos de este número}

Dra. Patricia Bermúdez, Facultad Latinoamericana de Ciencias Sociales FLAC-

SO-Ecuador

Dra. Saudhi Batalla. Escuela Nacional Antropología e Historia, México

Dr. Ulises Unda Lara. Western Ontario University, Canadá

Dr. Julián García Labrador. Universidad Politécnica Salesiana

Dr. Jordi Grau Rebollo. Universidad Autónoma de Barcelona

Dr. Hugo Burgos, Universidad San Francisco de Quito, Ecuador

Dr. Christian León, Universidad de Buenos Aires

Dr. Carlos Flores, Universidad Autónoma del Estado de Morelos, México

Dra. Elisenda Ardevol, Universidad Abierta de Cataluña, Barcelona

Dra. María Fernanda Troya. Facultad Latinoamericana de Ciencias Sociales FLACSO-Ecuador

Dra. Ana Paula Alves Ribeiro, Universidade do Estado do Rio de Janeiro

Dra. Mariana Xochiquétzal Rivera García. Universidad Autónoma Metropolitana Ciudad de México, México

Dr. Xavier Andrade, Universidad de Los Andes, Colombia

Dr. Sebastián Granda, Universidad Politécnica Salesiana, Ecuador

Msc. Franco Passarelli. Facultad Latinoamericana de Ciencias Sociales FLAC-

SO-Ecuador

Msc. Johrman Giraldo Obando. Facultad Latinoamericana de Ciencias Sociales FLACSO, Ecuador.

Msc. Eduardo Henríquez Mendoza. Universidad Autónoma de Barcelona

Msc. Hugo Chávez. Universidad Autónoma Metropolitana Unidad Iztapalapa, México

Msc. William Aguilar Rodríguez, Universidad Técnica de Ambato, Ecuador

MSc. Diego Yela, Facultad Latinoamericana de Ciencias Sociales FLACSO-Ecuador

Msc. Pablo Vásquez Padilla, Universidad Politécnica Salesiana, Ecuador

Dr. Fausto Sáenz, Universidad Politécnica Salesiana, Ecuador

Mg. Fredy Aguilar, Universidad Técnica de Ambato

Dr. David Chávez, U. Central del Ecuador

Mg. Alejandra Delgado, Pontificia Universidad Católica del Ecuador 


\section{Consejo Editorial Institucional UPS (Publishers Council UPS)}

\section{Consejo de Publicaciones (Board of Publications)}

Dr. Javier Herrán Gómez, sdb. Universidad Politécnica Salesiana, Ecuador Dr. Juan Bottasso Boeti, sdb. Universidad Politécnica Salesiana, Ecuador MSc. Juan Pablo Salgado, Guerrero, Universidad Politécnica Salesiana, Ecuador Dr. Luis Álvarez Rodas, Universidad Politécnica Salesiana, Ecuador Msc. Fabricio Freire, Universidad Politécnica Salesiana, Ecuador MSc. José Juncosa Blasco, Universidad Politécnica Salesiana, Ecuador MSc. Jaime Padilla Verdugo, Universidad Politécnica Salesiana, Ecuador Dra. Floralba Aguilar Gordón, Universidad Politécnica Salesiana, Ecuador MSc. Sheila Serrano Vicenti, Universidad Politécnica Salesiana, Ecuador Dr. John Calle Sigüencia, Universidad Politécnica Salesiana, Ecuador Dr. René Unda Lara, Universidad Politécnica Salesiana, Ecuador Msc. Betty Rodas Soto, Universidad Politécnica Salesiana, Ecuador MSc. Andrea De Santis, Universidad Politécnica Salesiana, Ecuador MSc. Mónica Ruiz Vásquez, Universidad Politécnica Salesiana, Ecuador

\section{Editor General UPS (General Editor UPS)}

Dr. Luis Álvarez-Rodas

\section{Consejo Técnico (Board of Management)}

MSc. Tania X. Barrezueta

Dr. Ángel Torres-Toukoumidis

\section{Servicio de Publicaciones (Publications Service)}

Hernán Hermosa (Coordinación General)

Marco Gutiérrez (Soporte OJS)

Paulina Torres (Edición)

Raysa Andrade (Maquetación)

Martha Vinueza Manosalvas (Maquetación)

\section{Traductor (Translator)}

Joaquín Crespo

\section{Editorial}

Editorial Abya-Yala (Quito-Ecuador)

Avenida 12 de octubre N422 y Wilson,

Bloque A, UPS Quito, Ecuador. Casilla 17-12-719

Teléfonos: (593-2) 3962800 ext. 2638

Correo electrónico: editorial@abyayala.org 



\section{ARTÍCULOS}

Circulación y distribución de cine etnográfico

en América Latina

Hugo Chávez Carvajal

Audiovisual etnográfico y tradición: una contribución

a la identidad y el desarrollo del municipio. La experiencia

de San Juan Atitán (Guatemala)

Luis Bruzón Delgado

Adornos corporales y género en las fotografías

etnográficas de Yámana/Yagán

Ana Butto y Danae Fiore

El etnógrafo y la cámara en la producción audiovisual

de productores informales

Eduardo Fabio Henríquez Mendoza

Los primeros viajes audiovisuales (1936)

de Rolf Blomberg en Ecuador

Franco Passarelli

\section{MISCELÁNEA}

Tejer y resistir. Etnografías audiovisuales y narrativas textiles

Mariana Xochiquétzal Rivera García

Investigación colaborativa y decolonización

metodológica con cámaras de video

Juan Carlos A. Sandoval Rivera 
Media-médium: entre la etnografía y el cine comunitario

Carolina Soler

La imagen en disputa. Cronistas barriales.

Producir desde los barrios

Néstor Daniel González, Cecilia Elizondo y Juan García

Percepción de la competencia mediática

y la formación en maestros chilenos

Pablo Maraver-López, Mari-Carmen Caldeiro-Pedreira

y Sandra Pérez-Lisboa

\section{NORMAS EDITORIALES}

Normas de publicación en «Universitas» 


\section{ARTICLES}

Circulation and distribution of ethnographic films in Latin America

Hugo Chávez Carvajal

Audiovisual ethnographic and tradition: a contribution to the identity and development of the municipality.

The experience of San Juan Atitán (Guatemala)

Luis Bruzón Delgado

Body ornaments and gender in the ethnographic

photographs of Yámana/Yagán

Ana Butto y Danae Fiore

The Ethnographer and the camera in the audiovisual

production of informal producers

Eduardo Fabio Henríquez Mendoza

The first audio-visual journeys (1936)

of Rolf Blomberg in Ecuador

Franco Passarelli

\section{MISCELLANEOUS}

Knit and Resist. Audiovisual ethnographies

and textile narratives

Mariana Xochiquétzal Rivera García 
Collaborative research and methodological decolonization with video cameras

Juan Carlos A. Sandoval Rivera

Media-medium: Between Ethnography and Communitarian Cinema

Carolina Soler

The image in dispute. Cronistas Barriales.

Produce from the neighborhoods

Néstor Daniel González, Cecilia Elizondo

y Juan García

Perception of media literacy and training

in teachers from Chile

Pablo Maraver-López, Mari-Carmen Caldeiro-Pedreira

y Sandra Pérez-Lisboa

NORMAS EDITORIALES

Publication guidelines in «Universitas» 


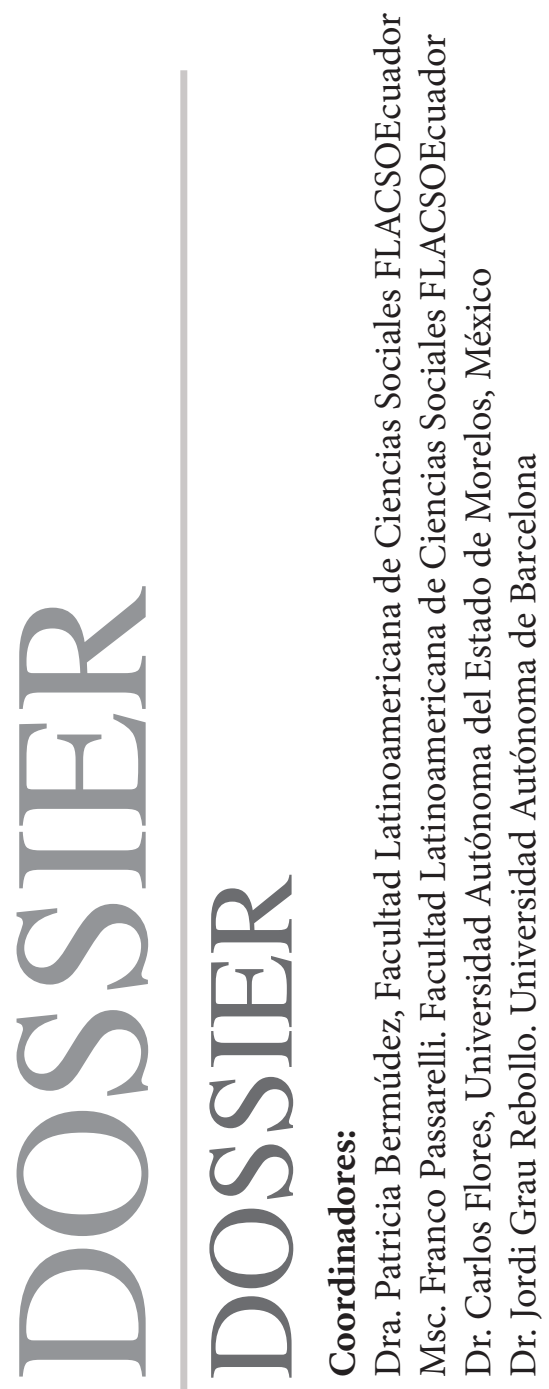





\title{
Circulación y distribución de cine etnográfico en América Latina
}

\author{
Circulation and distribution of ethnographic \\ films in Latin America
}

\author{
Hugo Chávez Carvajal ${ }^{1}$ \\ hugchvzc@gmail.com
}

\begin{abstract}
Resumen
El presente trabajo reflexiona sobre los circuitos y espacios de exhibición para el cine etnográfico en América Latina. Si bien la antropología visual, como el techo que suele arropar a este cine, goza de buena salud y cada año se generan nuevos proyectos de formación e investigación en la región, no ha pasado lo mismo con la difusión y exhibición a pesar de la larga tradición de cine documental vinculado a la mirada antropológica en países como Argentina, Colombia y México. En la última década, de manera paralela, han cambiado de forma significativa las lógicas de circulación y consumo de cine. Tal escenario plantea nuevas oportunidades. El objetivo es doble, por una parte busca analizar cuál es la importancia de construir espacios para la formación de públicos como lo son festivales y muestras. Por la otra intenta proporcionar una guía para quienes están interesados en distribuir trabajos audiovisuales de corte etnográfico.
\end{abstract}

\section{Palabras clave}

Antropología visual, cine etnográfico, festivales, distribución, exhibición, América Latina.

\begin{abstract}
While visual anthropology, as the roof under which is usually wrapped this films, enjoys good health in the region and new educational and research projects are generated every year, It has not been the same with the diffusion, distribution and exhibition despite the long tradition of documentary film linked to the anthropological view in countries such as Argentina, Colombia and Mexico. In the last decade, in parallel, they have significantly changed the logic of consumption and circulation of films. This scene presents new opportunities. The purpose is twofold, on one side analyzes the importance of building spaces for the formation of audiences such as festivals and exhibitions, starting from the premise that the future of every film depends on how it can reach the people. By the other side seeks to provide material for consultation and guidance for those interested in distributing audiovisual works of ethnographic cutting.
\end{abstract}

\section{Keywords}

Visual anthropology, ethnographic cinema, festivals, distribution, exhibition, Latin America.

Forma sugerida de citar: Chávez Carvajal, Hugo (2017). Circulación y distribución de cine etnográfico en América Latina. Universitas, XV(27), pp. 19-43.

1 Doctorante Universidad Autónoma Metropolitana-Iztapalapa México.

Orcid: 0000-0003-1440-8608. 


\section{Introducción}

La antropología visual, hoy más que nunca, atraviesa por un interesante momento en América Latina. Si bien las iniciativas académicas son jóvenes en relación a las de otras latitudes como Europa y tienen puntos de confluencia con las diferentes tradiciones de la disciplina, también de innovación y ruptura. En las últimas décadas se han abierto diplomados, seminarios, coloquios, laboratorios, programas de maestría y en menor medida revistas ${ }^{2}$, festivales, cineclubes y muestras de cine etnográfico. Los temas abordados son amplios. Nos encontramos frente a un campo de fronteras difusas en el que métodos y objeto están siempre en mesa de discusión, generado posibilidades de experimentación y diálogo.

En este contexto está surgiendo un interesante circuito de colaboración e intercambio entre investigadores, realizadores y gestores culturales (principalmente de Chile, Argentina, Perú, Ecuador y México). Dicho circuito opera más a nivel interpersonal que institucional, pero permite vislumbrar la conformación de redes de trabajo y colaboración entre universidades e institutos. Sin embargo, aunque también el cine etnográfico latinoamericano ha seguido reinventándose, principalmente fuera del ámbito académico, los espacios para su difusión y distribución (relevantes porque incentivan no solo la producción, sino también la formación de públicos) son todavía muy pocos. No obstante, Olatz González-Abrisketa y Aída Vallejo (2014, p. 61) encuentran que están crecido (principalmente en Europa) los espacios para la exhibición de trabajos audiovisuales relacionados con la antropología visual.

El presente artículo tiene como propósito reflexionar sobre ¿cuál es la importancia de que exista un circuito de exhibición especializado en nuestra región?, ¿qué tan necesario es y por qué? Si bien, en las últimas dos décadas se han consolidado los festivales de cine en América Latina ¿por qué los espacios para el cine etnográfico siguen siendo escasos? abordar estas preguntas, implica necesariamente pensar con detalle qué estamos entendiendo por cine etnográfico en un sentido amplio, quiénes hacen y ven estos filmes, cómo interpretamos a la luz de hoy las tensiones tradicionales entre

2 Una de las más representativas es la Revista Chilena de Antropología Visual: www.rchav.cl/. También la revista-blog E-Imgen editada por el Centro de Estudios de la Imagen Sans Soleil (CEISS) y el Área de Antropología Visual de la Universidad de Buenos Aires (AAV): http://www.e-imagen. net/e-imagen/ 
los mundos académicos y cinematográficos, pero también, qué concebimos cómo la finalidad de estas películas y la forma ideal para su circulación. De igual manera busca ser también, un material de consulta para quienes estén interesados en distribuir cine etnográfico en América Latina a través de una radiografía general de los lugares donde ha encontrado espacio en los últimos años.

\section{El inicio de un matrimonio complicado: fotografía, cine y antropología}

Las discusiones sobre imágenes y su uso han encontrado espacio en diversas disciplinas de las ciencias sociales, sin embargo, es tal vez en la antropología donde se han desarrollado con mayor solidez. En buena medida tiene que ver con la propia historia de la disciplina como productora de imágenes y con el peso que la mirada tiene en su quehacer. Situado desde aquí voy a plantear dos preguntas ¿podemos pensar en la etnografía, sin el acto de mirar, sin la observación?, ¿podríamos vislumbrar como materia prima de la antropología a la palabra sin la mirada?

Cierto es que en el trabajo antropológico existen diversas posibilidades que no están ligadas al acto de mirar, pero sin duda, la mirada ocupa un lugar muy importe sobre el que hay que reflexionar. "Es posible decir que la antropología gira en torno a las estrategias de la mirada y el hecho de mirar se convierte en un espacio estratégico. Una vía de acceso al universo del otro, que al mismo tiempo posibilita un lugar de construcción, significación y sentido" (Mier, 2009).

Prácticamente desde que la fotografía y el cine surgieron con la sociedad industrial de finales del siglo XIX fueron utilizados por la antropología, dando pie a nuevos campos de exploración. Las imágenes se entendían básicamente como un soporte que reafirmaba la veracidad de la información levantada en campo (Edwards 2011, p. 161). Su supuesta transparencia daba autoridad a la empresa etnográfica, que realizada en lugares remotos solo tenia la descripción y el dibujo para dar cuenta de las sociedades estudiadas. Los primeros pasos vinieron de Inglaterra, Francia y Estados Unidos.

En la manera moderna de conocer, observa Susan Sontag (2007, p. 134), pareciera que debe haber imágenes para que algo se convierta en real. Sin embargo, en esta manera de mirar, la realidad es principalmente apariencia. 
La fotografía y el cine son antes que nada maneras de mirar, no la mirada misma. Destacados antropólogos, que no solemos relacionar con imágenes, como Franz Boas, integraron la fotografía de forma periférica a sus investigaciones. En las décadas subsecuentes, no sin algo de desconfianza, otras figuras clave como Malinowski (en los veinte) y Lévi-Strauss ${ }^{3}$ (en la segunda mitad de los treinta) utilizaron la fotografía porque les permitía capturar aspectos visuales relevantes para sus notas de campo ${ }^{4}$.

El cine etnográfico, en el que me centraré, es una de las miradas más antiguas y reconocidas de la antropología visual (Ruby, 2007). La revolución tecnológica tuvo incidencia inmediata en su desarrollo, por ello, desde siempre ha trabajado con las innovaciones tecnológicas, construyendo métodos de investigación y representación frente a las vías tradicionales de la palabra. En El hombre y la cámara Jean Rouch ${ }^{5}$ (1995, pp. 103-104) describe como el cine etnográfico avanzó rápidamente con el desarrollo de equipos portátiles acelerado por la guerra ${ }^{6}$. Gracias al surgimiento en los años veinte del $16 \mathrm{~mm}$, se pudieron realizar trabajos de investigación visual en la siguiente década como los de Mead y Bateson en Bali.

Esas primeras producciones se contraponían a la noción del documental como forma de arte ${ }^{7}$, estaban pensadas solo para el trabajo académico. Los documentalistas en cambio, separaban el cine documental ${ }^{8}$ de las imágenes descriptivas de lo cotidiano que hacían los antropólogos. Para esta pareja de

3 Dichas imágenes se pueden consultar en: http://pueblosoriginarios.com/recursos/colecciones/strauss/ brasil

4 Naranjo (2006, p. 18) plantea que desde finales del siglo XIX, la fotografía fue adquiriendo una mayor relevancia en los trabajos de campo, pero que fue a partir de Malinowski cuando devino un método de trabajo utilizado por muchos antropólogos. "Estos investigadores se caracterizaron más por utilizar la fotografía y por incluirla en sus publicaciones que por realizar una labor teórica en torno a ella.

5 "Fue con el intento de satisfacer nuestras demandas de ligereza y solidez como se perfeccionaron grabadoras y cámaras portátiles, utilizadas en un principio por realizadores estadounidenses como Leacock y franceses como Michel Brault y yo" (Rouch 1995, p. 104). Véase The Camera That Changed The World https://vimeo.com/50533709

6 Brigarde (1995, pp. 32-41) pone de relieve, que el desarrollo de las capacidades estéticas influyó decisivamente en el estilo del cine etnográfico cuando éste se estableció ya como un género después de la segunda guerra mundial.

7 En esta mirada la subjetividad aparece en primer plano, la propuesta de Mead, en cambio, era situar los dispositivos como si se tratara de "una mosca en la pared" con la intención de intervenir lo menos posible.

8 Para Grierson, por ejemplo, el documental debe ser una forma de arte más que el registro mecánico de la realidad. "Considerar el cine documental como un mero documento ignora la formación creativa que constituye un elemento inevitable de todas las películas documentales" (Plantinga, 2011). 
investigadores, señala Ardévol (2008, pp. 40-41), “(...) no se trataba solo de una máquina para registrar datos, sino también de un instrumento que revolucionaría la propia práctica etnográfica y la elaboración teórica". Mead consideraba importante pensar que aunque la antropología había privilegiado las palabras, su contacto con la producción de imágenes, le agregó nuevos significados.

Tal relación entre imágenes y antropología, fue nombrada en los cuarenta por la propia Mead como "antropología visual”. Poco a poco, fue ganando un mejor posicionamiento ante la antropología académica, convirtiendo a la imagen en un camino posible dentro de la práctica científica (Pink 2006, p. 14). Para los años cincuenta, ya era una disciplina institucionalizada con especialistas y críticos reconocidos. El cine se transformó en una herramienta educativa de gran utilidad para muchos antropólogos culturales de los Estados Unidos y esa fue su principal finalidad y mecanismo de difusión (sigue siendo una de sus ventanas principales).

Más o menos en ese periodo y antes de que se hablara con fuerza de reflexividad en antropología, Jean Rouch (que circulaba más en los espacios del cine que en los académicos) empezó a filmar y a explorar esas ideas. A diferencia de Mead no buscaba el apego a la realidad. Para él, la corriente positivista del cine etnográfico tenía un carácter marcadamente etnocéntrico y colonialista. El cinema verité proponía la experimentación con la cámara implicando en el proceso a los personajes y situando como eje para la producción de conocimiento a la reflexividad (Canals, 2011, p. 63).

Del otro lado del mundo, el cine etnográfico estadounidense, peleaba con limitaciones narrativas al tratar de retratar la realidad tal cual es pero, encontró un camino con los realizadores del direct cinema de mediados de los sesenta. Ellos abogaban por una estética de la autenticidad que evitara las manipulaciones del director. Estas películas, pensadas para los circuitos cinematográficos, incorporaban conceptos de desarrollo de personaje y subjetividad, rechazados por la antropología, pero a diferencia de otros cines, respondían a cuestiones sociales de las que estamos enterados de modo consciente $^{9}$ (Loizos, 1997, pp. 81-85). Ya en los ochenta, David MacDou-

9 Leacock (The Children Were Watching,1961), Pennebaker (Monterrey Pop, 1968) y Frederick Wiseman (Titicut Follies, 1967) trataban de minimizar el efecto de su presencia e intentaban dejar que los sucesos se produjeran como si ellos no estuvieran ahí. Sin embargo les era inevitable controlar la producción de la película. 
gall criticó las vertientes observacionales más radicales y desarrolló lo que llamó "cine transcultural". En él concibe como un cruce de perspectivas culturales al encuentro entre el grupo representado y los realizadores. Cuando los sujetos se sienten implicados, describe, es porque la película se ha estructurado en función de sus propios intereses. El cine de MacDougall se exhibe principalmente en circuitos especializados y en el ámbito académico.

En América Latina aunque existen una rica y larga tradición en la mirada antropológica a través de la fotografía y el cine, ${ }^{10}$ como señalan Zirión (2017), Zamorano y Andrade (2012, p. 11), no pasó lo mismo con la antropología visual como disciplina académica; las discusiones sobre imágenes en la antropología latinoamericana no se desarrollaron en un ámbito especifico hasta hace relativamente poco. La reflexión teórica y la formación en universidades y centros de investigación, no rebasan las dos décadas. Los posgrados son aún más jóvenes, el de FLACSO-Ecuador lleva nueve años, el de la PUCP unos pocos menos.

Los laboratorios de antropología visual en las universidades de la región, por ejemplo, serían ideales para incentivar la producción, distribución, exhibición y difusión de cine etnográfico, sin embargo suelen estar situados al margen de las estructuras académicas y por lo regular (aunque claro no todos) se convierten en lugares cuya tarea principal es el préstamo de equipo y el registro de eventos. Si bien algunos tienen vida más allá de esto, en lo general, su trabajo tiene poca difusión y no logra una circulación fuera de las propias instituciones.

Quizás es en el cine colaborativo ${ }^{11}$ donde se encuentran las mayores aportaciones de América Latina a la historia del cine etnográfico. Este cine (en el que se puede pensar buena parte de la obra de Rouch y MacDougall) tuvo un impulso grande en la antropología con la "crisis de la representación" "12, (sobre todo en la realizada en inglés) en la que se hicieron

10 Para Zirión (2017) esta mirada etnográfica se expresa en México a largo del siglo XX, desde el registro fílmico de la Revolución, pasando por las filmaciones de Manuel Gamio y Miguel Covarrubias, las cintas de propaganda indigenista, el cine de Nicolás Echevarría, el movimiento de documentalistas urbanos, el trabajo de varios colectivos de video indígena y otros medios comunitarios.

11 Una referencia para entender la historia de los proyectos participativos y su relación con el desarrollo tecnológico es la sección Participatory del proyecto interactivo Moments of Innovation, del Open Doc Lab del MIT.

12 "Si en una representación general de una cultura o alguna subcultura es posible encontrar por la vía intuitiva o con métodos de observación razonables y objetivos algo que la gente no había notado o de cuya importancia no se había dado cuenta, entonces pienso que la antropología visual habrá demostrado su valor. No deberíamos tener tantas dudas acerca de la autenticidad de los medios de 
visibles los fantasmas del origen colonialista y se comenzó a poner en tela de juicio la autoridad del etnógrafo. Si bien los proyectos pioneros vinieron de Estados Unidos, la URSS, Francia y Canadá ${ }^{13}$; existe una fuerte tradición en nuestra región que tiene raíces en el cine militante de mediados de los setenta.

Uno de los ejemplos más significativo es el trabajo de Jorge Sanjinés, quien desarrolló en el libro Teoría y práctica de un cine junto al pueblo (1979) una propuesta de cine participativo. El trabajo de este autor, como mucho del tercer cine, se proyectaba inicialmente en espacios populares (como asambleas o cineclubes) y posteriormente, conforme fue creciendo su fama y prestigio, los festivales internacionales comenzaron a programar sus películas. Más inmerso en el campo que nos ocupa y con menos visibilidad fuera de los circuitos especializados, destaca el cine "etnobiográfico" de Jorge Prelorán ${ }^{14}$. Partiendo de largas charlas, de manera cercana y comprometida, documentaba la región, sus problemáticas y la forma en que las personas han logrado vivir en ese medio. Prelorán no se sentía del todo cómodo con "la etiqueta cine etnográfico", así que no estaba después tan preocupado por mostrar su trabajo en los espacios antropológicos. Paradójicamente son los que están más interesados en su obra actualmente.

Así pues, en toda la región se encuentran diversos proyectos en activo como el emblemático Video nas Aldeias de Brasil, Ojo de Agua Comunicación en México y otros, de formación más reciente, dedicados a la educación y difusión como Acampa Doc en Panamá y el Campamento Audiovisual Itinerante en México, entre otros. En las vertientes colaborativas (de las que existen diversas modalidades, hoy potenciadas muchas de ellas, por los medios interactivos), en rasgos muy generales, se buscan formas más horizontales, ricas y dinámicas de intercambiar conocimientos e interpretacio-

representación. ¿Qué otra cosa tenemos? Pienso que todo lo que los antropólogos tienen es su sensibilidad" (Gardner en Zirión y Flores, 2009, p. 165).

13 Algunos de los proyectos más representativos de los inicios son: In the Land of the Head Hunters (1914) de Edward S. Curtis, Nanook of the North (1922) de Robert Flaherty, Kino Eye (1924) de Dziga Vertov, el Cine-Tren de Aleksander Medvedkin (desarrollado en los treinta) y la serie de televisión Challenge for Change (1967-1980) de la National Film Board of Canada.

14 Decía Prelorán sobre su trabajo (1987, p. 114): "Mis películas tratan de quienes rápidamente devienen mis amigos, y en cuyas vida entro con muchos deberes y responsabilidades. En tal sentido, las películas adquieren un matiz de subjetividad dado por mi visión y relación particular con aquella gente". 
nes culturales en los procesos creativos de una película ${ }^{15}$. Cada vez son más las iniciativas creadas por las propias comunidades.

No quiere decir que dichos proyectos actúen sobre un campo neutro y que por sentado, se desdibujen los roles y jerarquías presentes regularmente en una película, pero sí que se plantea no imponer sentidos, construir colectividades y dialogar directamente con las comunidades involucradas; muchas veces están pensados para difusión local y no se enfatiza su carácter cinematográfico, sino su capacidad de incidir y reflexionar en torno a las problemáticas de las comunidades donde se realizó. Algunos de estos trabajos circulan en circuitos especializados otros se difunden por medios locales y/o digitales.

El documental colaborativo describe Antonio Zirión (2015, pp. 57-59) es un tipo de producción audiovisual coherente con la perspectiva intercultural de la antropología contemporánea y con la que, se vislumbra una interesante sinergia. De la misma forma observa, en los últimos años, una tendencia marcada en incluir metodologías participativas en la investigación antropológica. Paradójicamente aunque existe una interesante producción académica en torno al tema en español (con investigadores como Adolfo Estalella y Tomás Sánchez Criado), señala el autor, las numerosas reflexiones, han permanecido aisladas en América Latina y se han sistematizado poco.

Si bien al cine etnográfico se le suele vincular con el documental observacional y expositivo, la variedad de propuestas es enorme y muchas de las fronteras que tradicionalmente conocíamos se están desdibujando en híbridos que pueden abordar diversas formas y géneros, haciendo cada vez más difíciles las clasificaciones, no sólo de las películas, sino también, de los espacios donde se muestran.

A continuación abordaré las discusiones recientes sobre las definiciones de antropología visual y cine etnográfico, con la intención de tener un panorama amplio por pensar cómo impactan en la circulación de una película y

15 "El observador está por fin descendiendo de su torre de marfil; su cámara, su grabadora y su proyector lo están conduciendo, a través de un extraño camino; y por primera vez, su trabajo no está siendo juzgado por un tribunal de tesis sino por las propias personas que fue a observar. Me refiero a esta extraordinaria técnica de retroalimentación como un contrapeso audiovisual. No se verá a un etnólogo observando su personaje como si se tratara de un insecto (dominándolos), sino como si éste fuese un estímulo para un mutuo entendimiento. Ese fue el inicio de lo que algunos de nosotros denominamos antropología compartida” (Rouch, 1995, pp. 117-118). 
en la conformación de espacios profesionales para su exhibición. Estamos, pues, frente a un terreno en el que no existen fórmulas ni pasos a seguir.

\section{De la antropología al audiovisual: tensiones entre academia y cine}

El tema de la mirada, señala Raymundo Mier (2009), "ha sido puesto de relieve por la reflexión filosófica, pero en el ámbito antropológico aparece muchas veces como una faceta tácita desplazada al ámbito de los métodos". Una condición estricta de la antropología que se piensa implícita. Daría la sensación, acentúa Mier, que efectivamente la antropología está completamente constituida sobre el acto de mirar. No es casual que se hable una y otra vez de la observación como una de las condiciones fundamentales de la antropología. Y es quizás por ello que nos cuesta tanto trabajo caracterizar la relación entre antropología e imágenes.

El título "antropología visual" pareciera entonces demasiado ambiguo; sin embargo es bajo esta etiqueta que se ha logrado establecer una tradición, un método y un objeto formal de estudio relacionado al uso social de las imágenes (León, 2012, p. 100). Con el pasar de los años y el afán por caracterizar con más detalle las distintas relaciones entre imágenes y antropología, han surgido nuevas formas de focalizar los objetivos y de nombrar los encuentros (algunas bajo el paraguas general de la antropología visual, otras separándose de ella totalmente).

Investigadores, como Carlos Flores, no rechazan del todo la idea de "antropología visual”, pero ponen énfasis en no perder del radar la importancia del sonido y proponen hablar de "antropología audiovisual". También hay quienes prefieren la etiqueta "etnografía audiovisual" para enfatizar el peso del trabajo etnográfico. En la misma línea se discute si es mejor hablar en "cine etnográfico" o en "cine antropológico", se les diferencia, regularmente, en medida de la carga teórica que tengan, sin embargo lo cierto es que muchos académicos y festivales no hacen diferencia alguna. Para nombrar las investigaciones que reflexionan sobre películas, de manera parecida a los film Studies, pero echando mano de herramientas antropológicas, por otra parte, hay quienes hablan de "Antropología del cine". Un buen ejemplo es el libro: Cine mexicano antropológico de Javier González Rubio y Hugo Lara Chávez. 
En cuanto al diálogo entre antropología, arte y filosofía ${ }^{16}$ se suele hablar de "antropología de la imagen o de lo visual". En estas últimas vertientes la producción es principalmente teórica. Desde la sociología se encuentra la "sociología audiovisual" que incluye el análisis, práctica de la investigación sociológica basada en imágenes. Por último, encuentro un creciente interés teórico desde la antropología por los llamados "estudios visuales" que abordan la producción de significado cultural a través de la visualidad.

Como es evidente la antropología visual no ha logrado desarrollar una definición unificada, sus características, fronteras y objetivos están siempre en debate ${ }^{17}$. Casi dos décadas atrás, Paul Henly (2001) escribió que el impacto de las imágenes en años recientes no había pasado desapercibido para la antropología académica, pero, al mismo tiempo, veía la existencia de cierta inseguridad en lo que es o debería ser la antropología visual.

Podemos encontrar dos líneas de trabajo muy presentes en América Latina. Por una parte se encuentra esta producción medial que tradicionalmente abarca el cine y la foto como instrumentos de investigación y difusión del que hacer etnográfico y por la otra, el estudio de la comunicación intercultural y la crítica de la representación visual de las culturas, que se inscribe mayoritariamente en los campos del análisis y la teoría.

Los más dogmáticos consideran que para que un trabajo audiovisual sea antropológico tiene que tener el mismo rigor de las investigaciones escritas, además claro, de afinidad temática y metodológica con la disciplina, un equipo que integre al menos un antropólogo profesional, etc. (estos trabajos suelen tener una movilidad muy limitada). Los más abiertos por el contrario, pueden llegar a pensar de relevancia antropológica toda producción que apele al encuentro con la "otredad".

Situados en polos extremos, como es evidente, ambos puntos de vista, plantean muchas dificultades. Una postura demasiado cerrada coarta las posibilidades de diálogo y limita mucho las formas de trabajo. Una totalmente abierta se puede diluir con facilidad y perder el rumbo. Encuentro que la ne-

16 Véase: ¿Qué es la antropología de la imagen? Entrevista con Hans Belting https://youtu.be/j8O90TYBtDw

17 Ruby (2007) encuentra tres tipos de antropología visual. La primera se concentra en la producción de filmes etnográficos y su uso educativo. La segunda al estudio de los medios de comunicación, por lo general televisión y cine. Y por último está, la antropología visual de la comunicación, que es la versión más amplia, abarca el estudio antropológico de todas las formas visuales y gráficas de la cultura, así como la producción de material visual con una intención antropológica. 
gociación entre ambas y un territorio por el que se puede pisar en firme, es pensar a la antropología visual como un punto de encuentro entre diversas disciplinas en el que imagen y sonido posibilitan al investigador formas de trabajo etnográfico más libres y canales para llegar a un público más amplio. Sin embargo, sí existe un conflicto que sigue presente y es difícil equilibrar, me refiero a la lucha entre quienes priorizan la antropología como el valor fundamental del cine etnográfico y quienes la supeditan al lenguaje cinematográfico (González-Abrisketa y Vallejo, 2014, p. 62).

Este conflicto, que para la discusión podemos transpolar también a la tensión entre producción de texto e imágenes, no es solo conceptual sino también practico. Por una parte son pocos los realizadores que participan en los debates teóricos sobre el tema, por la otra las estructuras académicas de la antropología suelen ser rígidas y rara vez contemplan la producción audiovisual como el formato principal para presentar una investigación. No existen apoyos especializados al menos en América Latina y los de las instituciones cinematográficas suelen ser muy cerrados y para los antropólogos es difícil obtenerlos. Por lo regular, aunque habría que discutirlo con mayor profundidad, tienen mejores posibilidades de ser levantados los proyectos que incluyen en el equipo de trabajo gente del cine y la antropología.

Pasa lo mismo con la exhibición. Por ejemplo, con los eventos especializados (cuyo circuito principal se encuentra en Europa) mientras que los más abiertos y asociados al cine documental (como el Festival Jean Rouch, Astra Film Festival y el Festival dei Popoli, etc.) están interesados en el lenguaje cinematográfico y las formas experimentales, programan trabajos de diversos realizadores sin importar su formación. Los más cerrados (como RAI Film Festival, Gottingen Ethnographic Film Festival y NAFA Film Festival, etc.) están concentrados en la tradición etnográfica académica, no se preocupan tanto en la forma y tienen criterios más rígidos de selección (GonzálezAbrisketa y Vallejo, 2014, p. 60). Aunque hay películas que se programan en ambos tipos de festival no siempre es así.

Desde la producción y distribución de las primeras películas "autodenominadas como etnográficas", existe una discusión sobre qué es lo que caracteriza a este cine, si en su realización se necesita o no un antropólogo y si las aulas y los eventos académicos son su principal canal de difusión. Más allá de buscar definiciones hasta el cansancio, al igual que Zirión (2015, p. 52), considero más fructífero preguntarnos ¿en qué sentidos podemos decir que una película se considera etnográfica? Un punto en el que suelen converger 
muchas aproximaciones, es en pensarlo como un campo que aborda la representación de la diversidad cultural ${ }^{18}$ englobando producciones en las que pueden o no participar antropólogos; para contar historias específicas, dentro del propio marco de referencia de quienes se están retratando, para evocar su cultura y hacerla significativa para una audiencia que puede o no ser especializada (Bishop, 2012, p. 45).

El carácter antropológico de una película o una fotografía puede tener más que ver con el proceso de realización, con el encuentro entre culturas, con la construcción de diálogos, que incluso, con el tema, los objetivos finales y los personajes (Zirión, 2015, p. 52). Por otro lado, Olatz GonzálezAbrisketa y Aída Vallejo (2014,p. 62), encuentran que para la mayor parte de antropólogos y cineastas es irrelevante hacer la distinción de lo que es o no cine etnográfico. En este sentido una película puede devenir etnográfica en relación del recorrido que tenga (el circuito de festivales en el que participe y los catálogos en los que se ofrezca, etc.).

La camiseta de la antropología, hay que anotar, no solo se la pone el realizador, sino también aquel que ve la película, la analiza, la comenta, la programa en un festival o la inscribe en un marco de discusión particular. No obstante, es muy importante poner de relieve, que no todas las producciones audiovisuales que se hacen desde la antropología son cinematográficas, ni intentan serlo, existen también piezas (cápsulas o reportajes por ejemplo) que están pensadas para otros espacios y que tienen otro tipo de difusión.

En América Latina y en general en el mundo, las películas más interesantes para la antropología visual ${ }^{19}$ (estoy pensando en aquellas que abordan la diversidad cultural, los conflictos sociales, la vida cotidiana, etc.), no son realizadas por antropólogos ni desde instituciones antropológicas -por supuesto hay honrosas excepciones- sino por cineastas independientes (basta con revisar la programación de los últimos años del Margaret Mead Film Festival, para hacerse de una idea al respecto) que echan mano de herramientas etnográficas (artistas, cineastas, comunicadores, etc. ${ }^{20}$ y muestran

18 Elizabeth Edwards (211,pp. 161-171) encuentra un giro en la forma en la que la antropología utilizó en un principio las imágenes, en las diversas críticas realizadas por los posestructuralistas y en la reacción posterior - desde la ya llamada antropología visual- en la que se discutía la relación de tales imágenes con el colonialismo, ya que éstas, se planteaba, contribuyeron a construir la dominación sobre las poblaciones étnicas al reforzar categorías estereotípicas.

19 Como un ejemplo concreto pienso en Calle López (2013) de Lisa Tillinger y Gerardo Barroso.

20 Véase el trabajo de los mexicanos Adriana Trujillo, Emilio Téllez Parra, Tania Ximena y Yollotl Alvarado. 
su trabajo en espacios diversos. Hablar de cine etnográfico, sin embargo, sigue teniendo sentido porque nos permite caracterizar el cine que aborda la diversidad cultural con afinidad a la antropología y discernir sobre la utilización de herramientas etnográficas en la producción audiovisual.

La exhibición, cuyo estudio va en aumento desde la antropología (un ejemplo significativo es el libro Film Festivals and Anthropology coordinado por Aída Vallejo y María Paz Peirano), juega un papel fundamental, porque ponerle ciertas etiquetas a una película, como "cine etnográfico", y concentrarse en un campo muy especifico puede ayudar a definir los mecanismos de legitimación, difusión, distribución y finalmente ayudarle a encontrar su público, pero también le puede cerrar puertas y ponerle camisas de fuerza.

Al respecto, Robert Gardner, comentó:

Me gustaría pensar que el futuro del cine etnográfico comprenderá el abandono de esta forma de referirse a cualquier filme. Crear una categoría de cine "etnográfico" dificulta los esfuerzos para explorar cinematográficamente la condición humana. Usar este término beneficia solo a los dogmáticos que prefieren ignorar el hecho de que todos somos miembros de una misma humanidad (Gardener en Zirión y Flores, 2009, p. 167).

Aunque no voy a entrar en los esfuerzo que han hecho investigadores como Bill Nichols y Carl Plantinga, para clasificar los tipos de documental que existen; considero importante dejar sobre la mesa con claridad que el cine etnográfico es diverso como los temas que aborda. Pasa lo mismo con los formatos. Si la antropología visual expandió a mediados del siglo pasado los límites de la propia disciplina repensando la posición del otro, su presencia como sujeto y no solo como objeto de estudio abriendo camino hacia la reflexividad; el siglo XXI abre posibilidades para pensar en el desarrollo de una antropología visual desde los nuevos medios (Gutiérrez, 2012, pp. 102-105).

Por ejemplo, bajo el crecimiento de la Web y la noción de cine expandido, han emergido artefactos crossmedia, como el documental interactivo ${ }^{21}$, que amplían el cuadro bidimensional clásico de la pantalla en formatos narrativos y de visualización, donde el espectador, en cierta medida se vuelve co-creador

21 Para profundizar sobre el documental expandido pueden verse la conferencia Flujos de lo visible: la expansión del documental de Josep Ma Català: https://vimeo.com/33016851. 
(Yáñez, 2011). Dichos documentales tienen una lógica distinta de distribución y difusión que amerita profundizar en otro trabajo. Lo cierto es que presentan nuevas posibilidades para las practicas mediales de la antropología. No todos los filmes tendrán el mismo campo de acción: algunos encontrarán un espectro mayor en los circuitos más cercanos al arte, otros en los académicos y de cine antropológico, otros en los circuitos del documental, etc. Lo cierto es que una tarea fundamental, que se suele dejar de lado (al menos por buen número de los antropólogos que tratan de hacer cine), es trabajar en la exhibición tanto como en la investigación y la terminación de la película.

\section{Un circuito intermitente: mapeo sobre festivales y muestras de cine etnográfico en América Latina}

Decía Luis Ospina, el documentalista colombiano, en una entrevista que cito de memoria, "que una de las funciones de un festival de cine es hacer visible lo invisible". Con esta idea que me sirve como punto de partida, Ospina se refiere a que una de las misiones de los festivales es mostrar el cine que tiene pocas salidas, el que no tendrá una corrida en salas comerciales, que no cuenta con un equipo de prensa y del que probablemente no nos enteraríamos por otra vía. Es decir, que uno de sus objetivos principales es el de ser un puente entre realizadores y público.

Aunque existen festivales de muy diversos tipos y temáticas (algunos competitivos con componentes de negocios e industria, otros más concentrados en la difusión y formación de públicos, etc.) Olatz González-Abrisketa y Aída Vallejo (2014, p. 67) los han clasificado en tres grandes grupos en relación a sus ámbitos de especialización. Voy sumar un cuarto: 1) Festivales de cine etnográfico; 2) Festivales de cine documental; 3) Festivales generalistas (se refiere a los festivales que tienen distintas categorías, por ejemplo, el Festival Internacional de Cine de Morelia) y 4) Festivales temáticos (me refiero a los que basan su programación en temas particulares, por ejemplo, medio ambiente o derechos humanos). Tal panorama dibuja diversas posibilidades para la circulación de una película, pero también plantea más preguntas sobre como caracterizar al cine etnográfico.

El listado que acompaña este trabajo solo contempla eventos especializados en cine etnográfico (por cuestiones de espacio no fueron incluidos certámenes de fotografía antropológica, ni festivales afines como los de cine 
indígena y cine social), si bien el foco es América Latina, con proyectos de: Brasil, Argentina, Perú, Ecuador y México; separados en mapas regionales, están incluidos festivales de todo el mundo con la intención de construir un panorama global, que pueda servir de apoyo para quienes desean construir una ruta. Como en todo mapeo es posible que se queden afuera algunas iniciativas, sin embargo, están incluidas las más representativas y consolidadas de la región. Ahora bien desde mi perspectiva -como antropólogo y realizador- una ruta de festivales idealmente, aunque pensemos nuestra película mayormente como etnográfica, debe contemplar a lo largo de su trayecto, en mayor o menor medida, los cuatro tipos de festivales (existen diversas bases de datos que se pueden consultar en línea). Sí es aceptado o no dependerá de distintos factores, pero quedarse sólo en el campo de la antropología sería disminuir la posibilidad de dialogar con un público más amplio, que es una de las posibilidades que no podemos dejar pasar por lo pequeño que suele ser la difusión del trabajo antropológico.

De las filmaciones que buscaban capturar la realidad tal cual es a la nueva ola de cine sensorial, hay un mundo de diferencia, pero en general los espacios focalizados en cine etnográfico no tienen tantas variaciones (aunque existen claro). A grandes rasgos se pueden dividir en dos rubros, que ya mencione antes, y voy a revisar un poco más.

El primero son los más abiertos, por ejemplo Espiello Festival Internacional de Documental Etnográfico de Sobrarbe, entiende en un sentido amplio al documental etnográfico como las producciones documentales cuya intención primordial son la de mostrar aspectos relacionados con las formas de vivir y entender la vida dentro de una cultura. En este rango pueden entrar muchas películas que no necesariamente se hicieron con herramientas antropológicas.

El segundo son los más cerrados, como el Society for Visual Anthropology Film \& Media Festival que define el cine y vídeo etnográficos en términos generales como obras creadas como resultado del trabajo de campo etnográfico o en las que se utiliza etnografía, son informadas o ilustradas por los principios de la teoría o metodologías antropológicas. En esta mirada también hay un sin fin de posibilidades, pero se pone el énfasis en el uso de metodologías antropológicas.

No siempre es tan fácil (ni tan necesario) decidir de qué lado se encuentra la balanza. Igualmente no todos los que producen cine considerado etnográfico están interesados en exhibir sus películas en el circuito antropológico. Un ejemplo significativo es el de los trabajos realizados por el Sensory Ethnogra- 
phy Lab de Harvard coordinado por Lucien Castaing-Taylor. Aunque conocen bien la tradición del cine etnográfico se suelen deslindar de ella, si revisamos el recorrido de sus películas Manakamana (2013), Leviathan (2012) y Sweetgrass (2009) vamos a encontrar que más festivales de gran renombre como Locarno y CPH:DOX, que festivales etnográficos. Si no supiéramos de donde vienen (aunque tienen consonancia con la corriente principal del cine observacional) tal vez las pondríamos más bajo el paraguas del cine experimental y sin embargo vienen de un laboratorio de etnografía sensorial.

Algunos ejemplos latinoamericanos que podemos revisar son los documentales Tiyarus (2015) de Emilio Téllez Parra y La piedra ausente (2013) de Sandra Rozental y Jesse Lerner. En cuanto a la primera el director no tiene formación antropológica y sin embargo podemos inscribir la película en el marco de la etnografía experimental. Su recorrido ha sido diverso, incluye festivales generalistas, otros de corte social y eventos académicos. La segunda esta dirigida por una antropóloga y un cineasta y escritor. Su ruta ha sido larga y diversa, si bien se le podría describir como cine antropológico, también podemos ponerla solo bajo el paraguas del cine documental. Tuvo estreno en salas y distribución en plataformas digitales. Describo esto para dar cuenta de lo complicado que pueden ser las clasificaciones, pero también lo diverso que llega a ser el camino de una película.

Aunque es verdad que las plataformas digitales han cambiado las reglas del juego drásticamente, es cierto también que en el mar de información actual necesitamos de ciertas herramientas para no perdernos en la bruma. Las revistas, las criticas y reseñas, los catálogos especializados, la programación de ciclos, muestras y festivales siguen siendo fundamentales para conectar con la gente. En América Latina dichos espacios, paradójicamente, suelen surgir en el marco de instituciones académicas como universidades y museos, pero también hay iniciativas independientes importantes, como Forumdoc: Festival do Filme Documentário e Etnográfico de Belo Horizonte (que en 2017 cumple 20 años) y las Jornadas de Antropología Visual (2005-2012), organizadas por el colectivo Etnoscopio. Si bien este proyecto no esta por ahora en activo, considero importante incluirlo porque de ahí se han derivado otras iniciativas. Las jornadas estaban compuestas por un coloquio académico, una exposición fotográfica y una muestra de documental mexicano contemporáneo que proyectaba los trabajos de una nueva genera- 
ción de documentalistas ${ }^{22}$ que surgió a finales de los noventa y principios del dos mil, abordando de manera interesante, crítica y diversa lo que sucedía en ese momento en el país. Si bien pocos de esos documentales habían sido realizados desde la antropología, las preguntas y discusiones generadas en torno a ellos desde nuestro campo, daban cuenta de las múltiples posibilidades para la realización e investigación en torno a los medios audiovisuales.

Posteriormente se sumó en colaboración con el Festival de Cine Documental de la Ciudad de México DOCSMX otra muestra retrospectiva que es la ya mencionada Cine entre Culturas, que tenía como objetivo hacer una revisión de la obra de los cineastas y colectivos más destacados del cine etnográfico como Jorge Prelorán, Jonh Marshal y Video nas Aldeas, Robert Gardner, Ojo de Agua comunicaciones, etc. Las jornadas terminaron en 2012. Posteriormente surgieron en México el Foro de Cine Etnográfico, el Coloquio Académico de Antropología Audiovisual y el Encuentro y Muestrario de Investigaciones Audiovisuales, que apenas se están consolidando.

Existen muy pocos festivales y muestras consolidados en la región. La gran mayoría son relativamente recientes. En total no suman más de 10 . Aunque cada año surgen iniciativas nuevas, pocas alcanzan visibilidad internacional. Sin lugar a dudas no es posible hablar de un circuito; me refiero a una conjunto de festivales, muestras, foros que interactúen entre sí y que generen intercambios, diálogos y que le permitan a los realizadores construir una ruta de difusión regional. Cabe señalar que muy pocas películas etnográficas tienen salidas comerciales, prácticamente no hay en la región distribuidores, ni catálogos especializados.

Latour (2008, pp. 53-56) encuentra que los grupos, no pueden existir sin un acompañamiento de formadores, voceros (que hablen a favor de su existencia, invocando reglas y precedentes) y cuestionadores. Los grupos, no son cosas silenciosas, sino más bien el producto circunstancial de todas las voces que hablan acerca de lo que es un grupo de quién corresponde a qué. "No importa que ejemplo se tome todos necesitan personas que definan lo que son, lo que deberían ser, lo que han sido". Ya existe una comunidad de realizadores,

22 Algunos de ellos son: Everardo González con La canción del pulque (2003) y Los ladrones viejos (2007), Eugenio Polgovsky con Trópico de Cáncer (2004) y Los Herederos (2008), Adrián Arce, Antonio Zirión y Diego Rivera Kohn con Voces de la Guerrero (2004), Natalia Almada con Al otro lado (2005) y El General (2009), Juan Carlos Rulfo con Del olvido al no me acuerdo (1999) y En el Hoyo (2006) y Lucia Gajá con Mi vida adentro (2007) entre otros. 
hay investigación y producción académica al respecto, pero no tenemos un marco institucional que provea fondos, haga difusión, distribución, etc.

Esto genera un cuello de botella, que no es ajeno a la divulgación del conocimiento antropológico. Tenemos producción independiente, pero no los mecanismos adecuados para que ésta llegue a la gente, por lo que el realizador deberá poner especial cuidado en la estrategia que utiliza para distribuir su trabajo y en el énfasis que le quiere poner a cada tipo de espacio posible. Los eventos dedicados al cine documental en la región gozan de buena salud, están creciendo enormemente y representan una ventana muy importante para los realizadores; sin embargo pocos de ellos contemplan componentes de antropología visual (talleres, muestras, foros, etc.). Sin embargo si existen colaboraciones y van en aumento.

Por ejemplo Transcinema de Perú tiene proyectos con la Maestría en Antropología Visual de la PUCP; DocsMX (antes DOCSDF) realizó durante varios años, en colaboración con Etnoscopio A.C., Cine entre Culturas (por ahora en pausa) y Ambulante, cada tanto incluyen en su programación trabajos etnográficos y eventos académicos afines. Por otra parte en las nuevas tendencias de los circuitos del cine contemporáneo, tanto en lo experimental como en lo independiente, se están diluyendo las fronteras tradicionales, importantes festivales de la región como FIC-Valdivia y FICUNAM han eliminado la división entre documental y ficción de sus secciones competitivas; en esta coyuntura el cine etnográfico desde sus vertientes más experimentales poco a poco se ha consolidado como un campo fértil de realización.

Por su parte, los festivales más sólidos de cine etnográfico en la región y con un perfil más claro son los brasileños, el ya mencionado Forumdoc.bh (más abierto y cargado hacia el documental) y el Festival Internacional do Filme Etnográfico do Recife (un poco más cargado hacia la antropología). Ahora bien, están surgiendo propuestas interesantes en el marco de congresos internacionales como el Foro de Cine Etnográfico (que va circulando por distintos congresos) y el LASA Film Festival con programaciones mucho más abiertas y arriesgadas que las que se suele encontrar en ese tipo de lugares, sin embargo todavía tienen poco público y ocupan una posición marginal. También es importante señalar el surgimiento del Festival de Cine Etnográfico de Ecuador, que recientemente celebró su segunda edición y está trabajando por consolidarse.

Como todos sabemos este tipo de espacios son sumamente necesarios, pero en general tienen poca proyección y requieren de mucho esfuerzo. La 
pregunta, por más contradictoria que pueda parecer es ¿si necesitamos crear nuevos festivales o si es más propositivo hacer alianzas con otros (generalistas o de documental) que ya tienen mayor alcance y difusión? creando a su interior muestras, eventos académicos y programas especializados.

Este breve recorrido intentó poner sobre la mesa la importancia de generar espacios especializados en la difusión de cine etnográfico y por otra parte, la relevancia de que este tipo de películas sean enviadas a foros no especializados, para ampliar su alcance y dialogar con un público más amplio. A continuación se encuentra un mapa mundial y un calendario sobre festivales de cine etnográfico.

Figura 1

Festivales de cine etnográfico

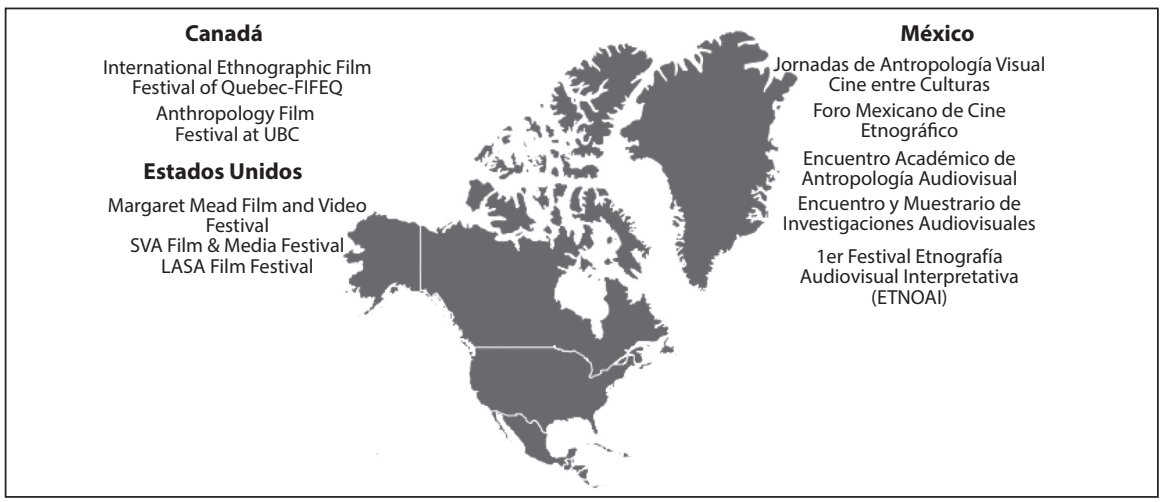

\section{Colombia}

Muestra audiovisual Congreso de Antropología, Bogotá 2017

\section{Ecuador}

Festival de Cine Etnográfico de Ecuador

\section{Argentina}

DocAnt Muestra del Documental Antropológico y Social

\section{Brasil}

Forumdoc.bh. Festival do Filme Documentário e Etnográfico de Belo Horizonte

Festival Internacionaldo Filme Etnográfico do Recife

Mostra Internacional do Filme Etnográfico 


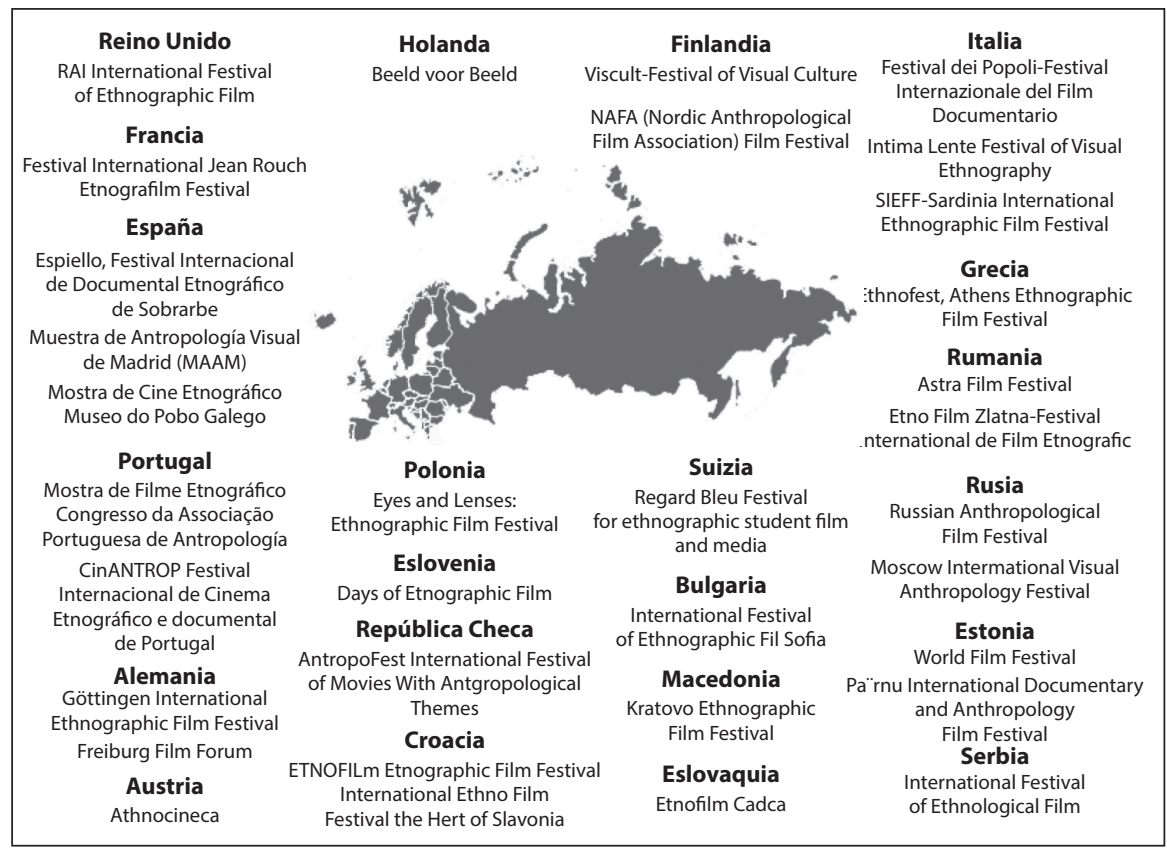

\section{Armenia}

Apricot Tree International Etnographic Film Festival

\section{Taiwan}

Taiwan International Ethnographic Fil Festival

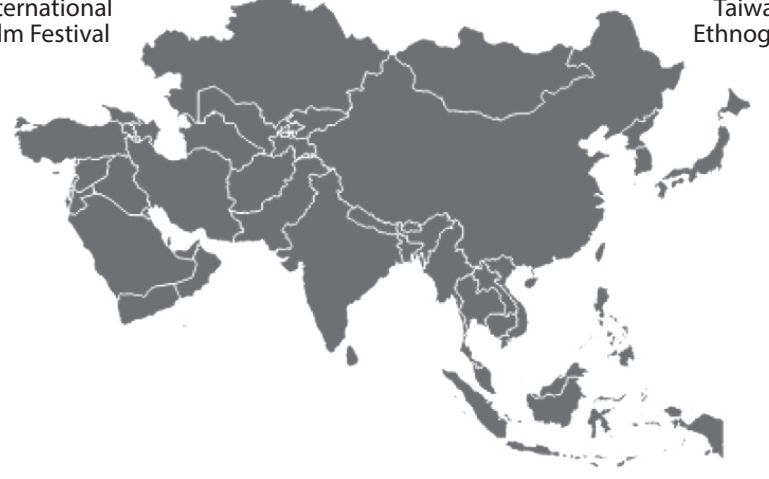




\begin{tabular}{|c|c|c|}
\hline \begin{tabular}{l}
\multicolumn{1}{c}{ Enero } \\
- \\
Antropofest Intematíonal Fim \\
Festival (Praga, República \\
Checa).* \\
- Ethnographic Film Festival of \\
Montreal (Canadá).
\end{tabular} & Febrero & \begin{tabular}{l}
\multicolumn{1}{c}{ Marzo } \\
- Days of Ethnographic \\
Film (Liubliana, \\
Eslovenia)** \\
- Eyes and Lenses: \\
Ethnographic Film \\
Festival (Varsovia, \\
Polonia). \\
- FIFEQ- International \\
Ethnographic Film \\
Festival of Quebec \\
(Canadá). \\
- World Film Festival \\
(Tartu, Estonia).
\end{tabular} \\
\hline $\begin{array}{l}\text { Abril } \\
\text { - } \text { Anthropology Film Festival at UBC } \\
\text { (Vancouver, Canadá). } \\
\text { - } \text { CinANTROP (Lisboa, Portugal). } \\
\text { - } \text { Espiello, Festival Internacional de } \\
\text { Documental } \\
\text { Etnográfico de Sobrarbe (Huesca, } \\
\text { España).* } \\
\text { - ETNOFILm Festival (Rovinj, } \\
\text { Croacia). } \\
\text { - Etnografilm Festival (París, } \\
\text { Francia). } \\
\text { - } \text { Russian Anthropological Film } \\
\text { Festival (Ekaterimburgo, Rusia). } \\
\text { - } \text { LASA Film Festival (Lima, Perú). }\end{array}$ & \begin{tabular}{l}
\multicolumn{1}{c}{ Mayo } \\
- Ethnocineca (Viena, Austria).* \\
- Freiburg Film Forum - \\
Ethnology (Alemania). \\
- Göttingen International \\
Ethnographic Film Festival \\
(Alemania).
\end{tabular} & $\begin{array}{l}\text { Junio } \\
\text { - Ethno film Festival - } \\
\text { The Heart of Slavonia } \\
\text { (Djakovo, Croacia). } \\
\text { - } \text { Mostra de cine } \\
\text { etnográfico } \\
\text { (Santiago de } \\
\text { Compostela, España). } \\
\text { - RAI International } \\
\text { Festival of } \\
\text { Ethnographic Film } \\
\text { (Reino Unido). } \\
\text { - Congreso de } \\
\text { Antropología (Bogotá, } \\
\text { Colombia). }\end{array}$ \\
\hline \begin{tabular}{l}
\multicolumn{1}{c}{ Julio } \\
- Pa“mu International \\
Documentary and \\
Anthropology Film Festival \\
(Estonia).
\end{tabular} & \begin{tabular}{l}
\multicolumn{1}{c}{ Agosto } \\
- \\
NAFA (Nordic Anthropological \\
Film Association) Film Festival \\
(itinerante). \\
- Etno Film Zlatna - Festival \\
International de Film Etnografic \\
(Zlanta, Rumania.)
\end{tabular} & $\begin{array}{l}\text { Septiembre } \\
\text { - SIEFF - Sardinia } \\
\text { International } \\
\text { Ethnographic Film } \\
\text { Festival (Italia). } \\
\text { - } \text { Viscult - Festival } \\
\text { of visual culture. } \\
\text { (Joensuu, Finlandia). } \\
\text { - Festimal de Ojo - } \\
\text { Festival de } \\
\text { Cine Etnográfico } \\
\text { (Quito, Ecuador). }\end{array}$ \\
\hline
\end{tabular}




\begin{tabular}{|c|c|c|}
\hline $\begin{array}{l}\text { Octubre } \\
\text { - Astra Film Festival (Sibiu, } \\
\text { Rumania). } \\
\text { - Kratovo Ethnographic Film } \\
\text { Festival (Macedonia). } \\
\text { - Moscow International Visual } \\
\text { Anthropology Festival (Rusia). } \\
\text { - Regard Blue (Zurich, Suiza). } \\
\text { - Taiwan International } \\
\text { Ethnographic Film Festival } \\
\text { (Taipei). } \\
\text { - Foro Mexicano de Cine } \\
\text { Etnográfico (México). } \\
\text { - Encuentro Académico de } \\
\text { Antropología Audiovisual } \\
\text { (México). } \\
\text { - Encuentro y Muestrario de } \\
\text { Investigaciones Audiovisuales } \\
\text { (Michoacán, México). } \\
\text { - DocAnt Muestra del Documental } \\
\text { Antropológico y Socia (Buenos } \\
\text { Aires, Argentina). } \\
\text { - Apricot Tree Etnografic Film } \\
\text { Festival (Yerevan, Armenia). } \\
\text { - 1er Festival Etnografía } \\
\text { Audiovisual Interpretativa }\end{array}$ & $\begin{array}{l}\text { Noviembre } \\
\text { - Aspekty. Festival of Visual } \\
\text { Anthropology (Torun, Polonia). } \\
\text { - Ethnofest Athens Ethnographic } \\
\text { Film Festival (Grecia). } \\
\text { - Etnofilm Cadca (Eslovaquia). } \\
\text { - Festival dei Popoli (Florencia, } \\
\text { Italia). } \\
\text { - Festival do Filme Documentario e } \\
\text { Etnográfico (Belo Horizonte, } \\
\text { Brasil). } \\
\text { - Festival International Jean Rouch } \\
\text { (París, Francia). - International } \\
\text { Festival of Ethnographic Film } \\
\text { (Sofía, Bulgaria). } \\
\text { - International Festival of } \\
\text { Ethnological Film (Belgrado, } \\
\text { Serbia). } \\
\text { - Margaret Mead Film and Video } \\
\text { Festival (Nueva York, Estados } \\
\text { Unidos). } \\
\text { - Mostra Internacional do Filme } \\
\text { Etnográfico (Río de Janeiro, } \\
\text { Brasil). } \\
\text { - SVA Film and Video Festival } \\
\text { (Estados Unidos). } \\
\text { - Festival do Filme Documentário e } \\
\text { Etnográfico de Belo Horizonte }\end{array}$ & $\begin{array}{l}\text { Diciembre } \\
\text { - Beeld voor Beeld } \\
\text { (Amsterdam, } \\
\text { Holanda). } \\
\text { - Intima Lente Festival } \\
\text { of Visual Ethnography } \\
\text { (Caserta, Italia) }\end{array}$ \\
\hline
\end{tabular}




\section{Bibliografía}

Bishop, J. (2012). La vida a través del mito: el desarrollo del cine etnográfico en la obra de John Marshall. En John Marshall, Patrimonio de la Humanidad. México: Etnoscopio A.C. y DOCSDF.

Brigard, E. (2003). The History of Ethnographic Film. En: Paul Hockings (Ed.), Principles of Visual Anthropology (pp. 13-43). De Gruyter.

Canals, R. (2011). Jean Rouch: Un antropólogo de las fronteras. Revista Digital Imagens da Cultura/Cultura das imagens, 1, 63-82.

Chávez Carvajal, H. (2015). Documental interactivo y antropología visual: reflexiones entorno a colaboración y autoría. (Tesis de maestría). Quito: FLACSO.

Edwards, E. (2011). Tracing Photography. En Marcus Banks y Jay Rubin (Comp.), Made to be Seen: Perspectives on the History of Visual Anthropology (pp. 159-198). Chicago IL: The University of Chicago Press.

González-Abrisketa, O. y Vallejo, A. (2014). Circuitos de distribución y espacios para la difusión del cine etnográfico contemporáneo: una guía práctica. España: Anales del Museo Nacional de Antropología.

González Rubio, J. y Lara Chávez, H. (2009). Cine Mexicano Antropológico. INAH, México.

Gutiérrez De Angelis, M. (2012). Antropología visual y medios digitales: Nuevas perspectivas y experiencias metodológicas. Revista de Antropología Experimental, 12, Texto 8, 101-112. España: Universidad de Jaén.

Henley, P. (2001). Cine Etnográfico: tecnología, práctica y teoría antropológica. Revista Desacatos. México: CIESAS.

León, Ch. (2012). Comentarios al dossier "Antropología visual en Latinoamérica" Íconos. Revista de Ciencias Sociales, 43, 99-106. Quito: FLACSO.

Mead, M. (2003). Visual Anthropology in a Discipline of Words. En Paul Hockings (Comp.), Principles of Visual Anthropology (pp. 3-10). New York NY: Mouton de Gruyter.

Mier, R. (2009). Ponencia presentada en la mesa Memoria y Olvido de las V Jornadas de Antropología Visual: Sentidos y sensaciones. Ciudad de México: Escuela Nacional de Antropología e Historia.

Pink, S. (2006). The Future of Visual Anthropology: engaging the senses. London: Routledge. 
Rouch, J. (1995). El hombre y la cámara. En E. Ardévol y Pérez Tolón (Ed.), Imagen y cultura. Perspectivas del cine etnográfico. Granada, Diputación Provincial de Granada.

Ruby J. (2007). The last 20 years of visual anthropology a critical review. Philadelphia, EE.UU: Temple University.

Sanjinés, J. (1972). Teoría y práctica de un cine junto al pueblo. México: Siglo XXI Editores.

Sontag, S. (2007). Al mismo tiempo: Ensayos y conferencias. Madrid: Editorial Mondadori 135-138.

Vallejo, A. y Paz, Peirano, M. (2017). Film Festivals and Anthropology. Cambridge Scholars Publishing. UK.

Yañez, M. (2011). Informe: documental interactivo. Con la realidad sí se puede jugar de http://antes.embed.at/article43.html

Zirión Pérez, A. (2015). Miradas cómplices: cine etnográfico, estrategias colaborativas y antropología visual aplicada Iztapalapa, Revista de Ciencias Sociales y Humanidades, 78, 45-70. México: Universidad Autónoma Metropolitana Unidad Iztapalapa Distrito Federal.

Zirión Pérez, A. (2017). La antropología visual y el cine etnográfico en México \#AnthroDay. México: Colegio de Etnólogos y Antropólogos Sociales, A.C. (CEAS)

Zirión Pérez, A., y Flores, C. (2009). Un chamán del cine etnográfico. Entrevista con Robert Gardner en México. Alteridades, 19(37), 159-169.

\section{Filmografía}

Al otro lado (2005) de Natalia Almada

Del olvido al no me acuerdo (1999) de Juan Carlos Rulfo

El General (2009) de Natalia Almada

En el hoyo (2006) de Juan Carlos Rulfo

La canción del pulque (2003) de Everardo González

La piedra ausente (2013) de Sandra Rozental y Jesse Lerner.

Los ladrones viejos (2007) de Everardo González

Los Herederos (2008) de Eugenio Polgovsky

Monterrey Pop (1968) de D.A Pennebaker

The Camera That Changed The World (2011) de Mandy Chang

The Children Were Watching (1961) de Richard Leacock 
Titicut Follies (1967) de Frederick Wiseman

Tiyarus (2015) de Emilio Téllez Parra

Trópico de Cáncer (2004) de Eugenio Polgovsky

Voces de la Guerrero (2004) de Adrián Arce, Antonio Zirión y Diego Rivera Kohn

Fecha de recepción: 19/06/2017; fecha de aceptación: 01/08/2017;

fecha de publicación: 01/09/2017 



\title{
Audiovisual etnográfico y tradición: una contribución a la identidad y el desarrollo del municipio. La experiencia de San Juan Atitán (Guatemala)
}

\author{
Audiovisual ethnographic and tradition: a contribution \\ to the identity and development of the municipality. \\ The experience of San Juan Atitán (Guatemala)
}

\author{
Luis Bruzón Delgado ${ }^{1}$ \\ lbruzon@demuca.org
}

\begin{abstract}
Resumen
Este artículo expone la experiencia desarrollada en el municipio de San Juan Atitán (Guatemala) mediante la realización del audiovisual etnográfico titulado "Los guardianes del tiempo",2, el cual recoge una tradición de elección de autoridades locales que fusiona prácticas heredadas de las épocas maya y colonial. Esta tradición es relevante desde diversos ángulos y supone una proyección hacia el desarrollo a la hora de plantear políticas públicas para el fortalecimiento de los gobiernos locales. La costumbre pretendía ser filmada y difundida para contribuir a su tangibilización y perpetuación como manifestación inmaterial de patrimonio cultural y buena práctica de organización social indígena. Para ello se planificó un acercamiento a la realidad de estudio con el propósito de contribuir a la comprensión colectiva de esta práctica y al fortalecimiento de la identidad local, mediante actividades de devolución comunitaria. Las conclusiones de la investigación demuestran la importancia y validez de la etnografía audiovisual aplicada a procesos de revitalización cultural y desarrollo local, como una manera de contribuir al campo de la comunicación para la transformación social en Centroamérica.
\end{abstract}

\section{Palabras clave}

Audiovisual, etnografía, cultura, tradición, indígenas, municipalismo.

Forma sugerida de citar:

Bruzón Delgado, Luis (2017). Audiovisual etnográfico y tradición: una contribución a la identidad y el desarrollo del municipio. La experiencia de San Juan Atitán (Guatemala). Universitas, XV(27), pp. 45-65.

1 Coordinador del área de Comunicación Social. Fundación DEMUCA. ORCID: 0000-0002-1958$788 \mathrm{X}$.

2 "Los guardianes del tiempo" puede visualizarse en: https://www.youtube.com/watch?v=9XPAECNrQds 


\begin{abstract}
This article summarizes the experience developed in the municipality of San Juan Atitán (Guatemala) by means of audio-visual ethnographic entitled "Los guardianes del tiempo", which collects a tradition of election of local authorities which merges practices inherited from the Mayan and colonial eras. This tradition is relevant from different angles and a projection towards the development when implementing public policies for the strengthening of local governments. The custom was intended to be filmed and disseminated to assist in their tangibilizacion and perpetuation as intangible manifestation of cultural heritage and good practice of indigenous social organization. So we planned an approach to the reality of study with the purpose of contributing to the collective understanding of this practice and the strengthening of local identity, through community return. The research findings show the importance and validity of the audiovisual Ethnography applied to processes of cultural revitalization and local development as a way of contributing to the field of communication for social transformation in Central America.
\end{abstract}

Keywords

Audiovisual, ethnography, culture, tradition, indigenous, municipalism.

\title{
La identidad cultural como factor para la cohesión social
}

En la era de las nuevas tecnologías de la información, de las transformaciones vertiginosas en las comunicaciones, del cambio de paradigma en los procesos de emisión-recepción de mensajes con el modelo "prosumidor" (Toffler, 1999), la cultura irrumpe como elemento de contrapeso y mantenimiento de las identidades, convirtiéndose en cuarto eje del desarrollo (Hawkes, 2001) y motivo de atención por parte de las conferencias internacionales, como lo demuestran en las últimas décadas las sucesivas convenciones y declaratorias de la Organización de las Naciones Unidas para la Ciencia, la Educación y la Cultura (UNESCO) -en especial las de 2003 y 2005- y otros organismos afines.

La cultura, como forjadora de identidades en contextos de una innegable multiculturalidad, acoge además el concepto de la tradición ${ }^{3}$, cuyos sig-

3 Proveniente del latín traditioo, -ōnis, entre las acepciones del término "tradición" que ofrece el diccionario de la Real Academia Española figuran las siguientes: transmisión de noticias, composiciones literarias, doctrinas, ritos, costumbres, etc., hechas de generación en generación; noticia de un 
nificados están en función de diversas variables, como la época y los fines particulares de historiadores, sociólogos, lingüistas, antropólogos o comunicadores. Arévalo (2004) le infiere un sentido de temporalidad, ya que cambia de generación en generación. Las diferentes culturas o grupos sociales varían sus tradiciones, en función de cada tiempo, influyendo, por tanto, en su identidad.

La tradición no es algo exclusivo del pasado, se renueva en el presente, abandona la obsolescencia de prácticas anacrónicas y representa la continuidad cultural de la herencia colectiva. Contiene en sí misma los gérmenes de la estabilidad y del cambio. Y el cambio, en términos de adaptación sociocultural, es consustancial a toda sociedad (Arévalo, 2004, p. 926).

La tradición, por tanto, con sus cambios, se reproduce desde el pasado con proyección de futuro, guardando simbolismos que contienen en sí mismos un sentido de visión hacia el desarrollo y la promoción social comunitaria. En el corazón de los montes Cuchumatanes, en el norte de Guatemala, perviven tradiciones dignas de consideración en procesos de (re) construcción colectiva de índole política y social, las cuales se convierten al mismo tiempo en una oportunidad para el etnógrafo audiovisual, quien, además, de su trabajo de investigación, podrá contribuir desde una perspectiva colaborativa a dicha construcción como mediador cultural. Desde los Acuerdos de Paz de 1996, que pusieron fin a 36 años de conficto armado interno, Guatemala es un país inmerso en iniciativas de desarrollo para superar sus índices seculares de pobreza y exclusión, los cuales afectan especialmente a las comunidades indígenas. Sin embargo, la cultura, la identidad, la tradición, quedan a menudo invisibilizadas, imponiéndose modelos verticales de intervención desde abordajes y actitudes arraigadas en el modelo occidental y economicista del desarrollo (Bruzón \& Hernando, 2016).

Paradójicamente, los proyectos de cooperación inciden en la importancia de la territorialización de las acciones, enfatizando la relevancia de lo local, de la fortaleza de las capacidades endógenas para la planificación y gestión de políticas públicas que hagan valer la autonomía municipal, teniendo para ello en cuenta la pertinencia cultural y, de esta manera, el lo-

hecho antiguo transmitida de este modo; doctrina, costumbre, etc., conservada en un pueblo por transmisión de padres a hijos. 
gro de objetivos como la integración social, la democracia y el desarrollo humano sostenible, equitativo y equilibrado (García González, 2005). En ese marco entra en juego la identidad cultural, la cual sintetiza y fomenta el capital social de las comunidades, sus distintas expresiones (objetos, ritos, ceremonias, festividades, artes, cosmovisión). Las expresiones culturales proveen una oportunidad para tejer relaciones de complementariedad, confianza y colaboración entre los distintos actores sociales, haciendo emerger el desarrollo del municipio como proyecto común para todos, sin olvidar que la identidad cultural de los municipios crea condiciones para el efectivo ejercicio de la gobernabilidad democrática, al contar con una comunidad más cohesionada, sobre la base de un sentimiento de pertenencia al ámbito territorial. Todo ello, en un espacio de comunicación, como el municipio, con sus múltiples mensajes e interlocutores (Bruzón \& Hernando, 2016).

Se puede colegir entonces que el patrimonio cultural en sus formas material e inmaterial puede situarse en una posición de prestigio en la configuración de políticas públicas municipales:

Que se entienda el porqué y el para qué de cada expresión cultural, que se tome conciencia de su verdadero valor para que se focalicen acciones, programas y proyectos en cada área, los cuales traerán beneficios incluso de índole económica a través de iniciativas de emprendimiento. En caso contrario, al menos contribuirá a la paz social, a la lucha contra el racismo, la exclusión social, al tiempo que fomentará el respeto a la pertenencia cultural y étnica de las personas que viven en los municipios (Max Araújo, comunicación personal, 26 de febrero, 2015) ${ }^{4}$.

Parece más que aceptable, por tanto, realizar una labor de etnografía, de mapeo, descripción e interpretación de las expresiones culturales, para la cual la función del investigador audiovisual será clave, más teniendo en cuenta la necesidad de trabajar en conjunto con las comunidades en el rescate de los simbolismos de la cultura. En numerosos casos éstos han sufrido rupturas en los procesos de endoculturación (Harris, 2001), producto de circunstancias como el propio conflicto armado, la pobreza, la permanente emigración de los más jóvenes a los Estados Unidos, entre otros factores co-

4 Max Araújo es actualmente el viceministro de Cultura y Deportes de Guatemala. 
adyuvantes en la desarticulación del tejido social. El caso de San Juan Atitán no escapa a ello.

\section{Los guardianes del tiempo, audiovisual etnográfico sobre la tradición de la elección de autoridades locales en San Juan Atitán}

\section{Justificación}

La Fundación DEMUCA y la Asociación Guatemalteca de Alcaldes y Autoridades Indígenas (AGAAI) produjeron este audiovisual etnográfico con el fin de sistematizar y difundir la forma de organización política de San Juan Atitán en torno a la elección de autoridades locales de este municipio del departamento de Huehuetenango, en el noroccidente del país. La idea surgió de la propia AGAAI, que contaba en su plan estratégico con un punto relativo al apoyo y promoción de las estructuras organizativas de los pueblos indígenas mediante acciones de comunicación que respetaran la identidad cultural y promovieran el diálogo intercultural. Los fines de la cooperación española, a través de la mencionada Fundación, socio estratégico de AGAAI, confluían en dicha visión. El resultado final fue un producto de 35 minutos de duración, que plasma esta tradición inmemorial, la cual conjuga costumbre, identidad cultural, gobernabilidad local y participación ciudadana.

El municipio de San Juan Atitán cuenta con unos 30000 habitantes. Prácticamente todos pertenecen a la etnia maya-mam y conservan costumbres ancestrales. Las más llamativas son la lengua mam, la cual es la más hablada, pues el castellano es poco utilizado por ellos y cuesta entenderles si hablan en este idioma. El otro gran distintivo de su identidad cultural es el traje tradicional, que conservan tanto mujeres como hombres. El hecho de que los hombres mantengan su vestimenta característica es casi una excepción en Guatemala, pues en la mayoría de municipios esta práctica ha desaparecido.

San Juan Atitán es una población eminentemente agrícola, que destaca por sus fuentes de agua, las cuales abastecen a otros importantes municipios de la zona. Por eso, sus prácticas ancestrales están relacionadas, en buena medida, con la conservación de los bosques que coronan las montañas circundantes a la localidad. Este sentido de respeto a los recursos naturales y de conciencia de preservación de las reservas acuíferas es una herencia de la cultura 
maya, que basa su cosmovisión en la simbiosis del ser humano con el medio ambiente. Por eso, en San Juan Atitán ha pervivido desde tiempos inmemoriales una figura de autoridad local llamada "guardabosques". Los guardabosques brindan un servicio ad honorem de vigilancia para evitar la tala de árboles, la cual a veces se produce por las propias condiciones de pobreza en las que vive la población o por la búsqueda de leña para usar la cocina o simplemente calentarse, pues el pueblo es frío -está a 2500 metros sobre el nivel del mar- y especialmente por la noche predominan las bajas temperaturas.

Junto a los guardabosques, hay una serie de autoridades adicionales -todas ellas trabajando igualmente de forma desinteresada- para apoyar el trabajo del gobierno local, es decir, el ayuntamiento (llamado "municipalidad" o "alcaldía municipal" en Centroamérica). De esta manera, el alcalde y los concejales han contado siempre con el apoyo de casi doscientas autoridades locales, que bajo diferentes denominaciones (alcaldes de costumbre, auxiliares, mayores, regidores y los propios guardabosques), han brindado su trabajo en diferentes áreas, para mantener los caminos, los puentes, el orden público, el buen funcionamiento de los mercados, el entorno natural, etc.

La elección las autoridades locales se ha venido realizando cada año en una ceremonia pública en la que participa toda la comunidad. Se trata de un rito que cuenta con simbolismos que se pueden encontrar en fuentes tradicionales de la cosmovisión maya, como el calendario o el Popol Vuh. El rito -que se recoge en el video- pone fin a todo un proceso de elección de dichas autoridades en función de los valores con que cuente la persona: honestidad, respeto, obediencia, solidaridad, entre otros. Cuatro regidores son los encargados de escoger a las autoridades y realizar el anuncio de forma pública. Quien es elegido ha de asumir el cargo y no puede renunciar a ello. Deberá dejar de trabajar un año para servir a la comunidad. Esta forma de organización indígena, pese a que en apariencia puede suponer una contradicción respecto al ordenamiento jurídico del país (nadie puede trabajar sin remuneración a cambio), está respaldada por el Código Municipal, el cual permite este tipo de prácticas basadas en la autonomía municipal.

El audiovisual plantea la disyuntiva emocional que atraviesa la localidad, pues el hecho de ser elegido para ser autoridad supone un gran esfuerzo económico en tiempos modernos. Por lo tanto, convertirse en autoridad local se ha ido transformando, más que en un elemento de satisfacción, en un problema, ya que las condiciones económicas de hoy en día no permiten con facilidad tener que abandonar un trabajo, ya sea agrícola, comercial, etc. 
Muchas autoridades locales, al ser elegidas, han de pedir préstamos o apoyo a familiares para poder mantenerse a ellos mismos y a sus familias durante el periodo que dura su trabajo comunal.

Otro aspecto reseñable es que esta tradición se ha mantenido solamente entre los hombres. Son ellos los que pueden ser elegidos, no así las mujeres. Este hecho podría interpretarse como un ejemplo de marginación hacia la mujer. Sin embargo, si algún hombre irrespeta a la mujer no podrá ser elegido como autoridad. Por otro lado, las mujeres han ido encontrando paulatinamente espacios de organización y participación, apoyadas por la municipalidad. Quizá, en consonancia con la revisión constante de la tradición propugnada por Arévalo (2004) como elemento de futuro, las mujeres puedan ser elegidas pronto como autoridades. El documental ofrece en consecuencia, una oportunidad no solo para tangibilizar la costumbre, sino para dialogar sobre ella en la búsqueda de elementos de equilibrio en su perpetuación y participación como forma de cohesión e inclusión social.

Figura 1

Estampas de San Juan Atitán el día de la elección de las autoridades locales

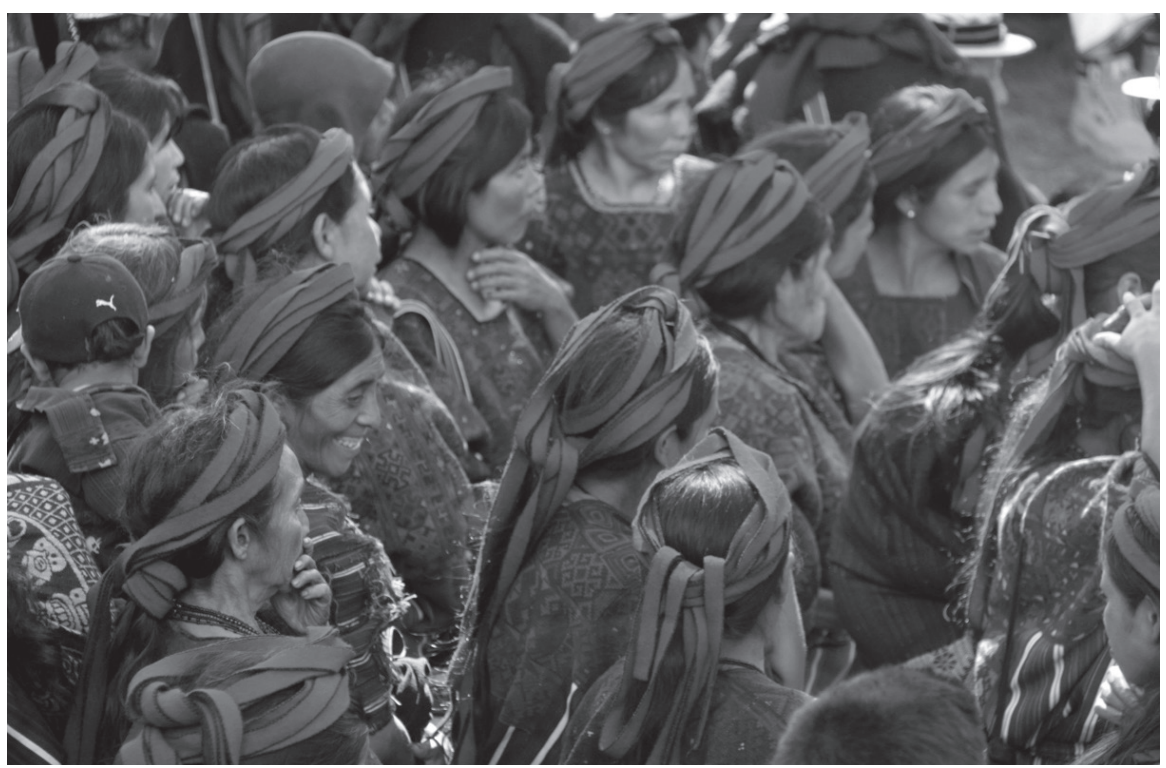




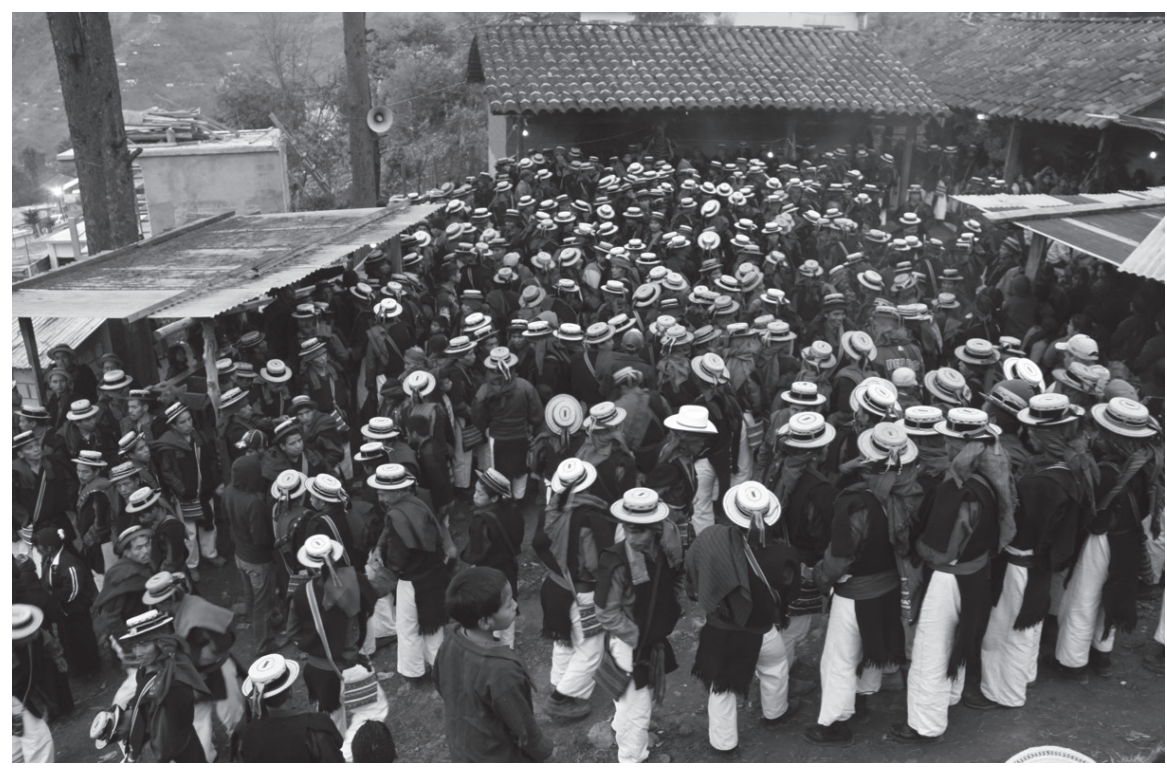

\section{Metodología}

\section{Etapa de producción}

La AGAAI realizó todos los esfuerzos posibles por facilitar la realización de este audiovisual, mediando para obtener, por parte de las autoridades de San Juan Atitán, el consentimiento para captar con la cámara la autenticidad de la tradición. Hubo, por tanto, una primera etapa de acercamiento respetuoso a la comunidad para lograr un consenso en los términos del trabajo que se pretendía acometer. El objetivo no era realizar un audiovisual con fines de investigación desde la perspectiva de la ciencia antropológica, sino construir una herramienta de comunicación para su uso divulgativo en foros de diálogo sobre la importancia de las formas de organización indígena en Guatemala, y de sensibilización hacia la población en general.

En consecuencia, el audiovisual final presenta un guión sobre la base de la investigación, incorporando entrevistas a los portadores de la tradición, así como una banda sonora y otros elementos técnicos para conferir una estética comunicativa adecuada para su presentación a diferentes públicos en el contexto del régimen municipal guatemalteco y, por extensión, centroamericano. 
La AGAAI apoyó la etapa de grabación con el aporte de dos personas indígenas que asistieron la filmación y facilitaron la comunicación con el etnógrafo mediante las traducciones al idioma mam y la mediación para la comprensión de las manifestaciones autóctonas. Después del trabajo de investigación del etnógrafo y la preparación del guion y montaje, la AGAAI lo validó para su posterior difusión.

La producción del video contó con los pasos establecidos desde una perspectiva de acercamiento ético a la misma. La observación participante se desarrolló en una pretendida condición de igualdad para la captación de los rituales propios de la elección de autoridades locales en su cotidianeidad (Pulido, Ballén \& Zúñiga, 2007; Micelli, 2009; Kapuscinski, 2014), hecho que ocurrió de forma sincrónica a la presencia del etnógrafo, acompañado de toda la carga simbólica propia de una tradición de estas características. En esta dimensión se pretendió un alto nivel colaborativo en la relación investigador-participantes (Lisón, 1999; Flores, 2005; Grau, 2002; Cárdenas \& Duarte, 2010; Espinosa, 2012; Ranocchiari, 2015; Zirión, 2015). La experiencia generó resultados positivos, pero supuso un reto constante para mantener la tensión a lo largo del proceso hasta la consecución del producto final. No fue fácil, dada la dependencia del compromiso y responsabilidad de los verdaderos protagonistas, cada uno de ellos con sus características, personalidad y códigos culturales.

El relato final cuenta con un nivel -a nuestro entender justificado y respetable- de autoridad etnográfica (MacDougall, 1995; Cadenas, 2008) por parte del etnógrafo, encargado de preparar el guión y el montaje sobre la base de la descripción y la interpretación. Incluso se utilizó una voz en off para facilitar la comprensión de una descripción densa (Geertz, 1987) a una audiencia (receptora/lectora) que, sin duda, incorporó igualmente sus interpretaciones y conclusiones -enriqueciendo, por tanto los discursos derivados del audiovisual-, como lo demostraron los foros de difusión e interlocución posteriores.

El propósito de la iniciativa de AGAAI patrocinando la realización de este audiovisual fue la de contribuir al diálogo y a la cohesión social, facilitando espacios democráticos de comunicación y retroalimentación para el fortalecimiento del Estado de Derecho. Hay que añadir que el audiovisual fue seleccionado para la fase final de algunos festivales internacionales (Espiello -España-, Ícaro -Guatemala- y otras muestras en diversos países a nivel local), lo cual contribuyó a su divulgación en círculos más amplios. 
Etapa de devolución

Mediante técnicas de focus groups y análisis de discurso (Santos, 1993; Alzaga, 1998; Íñiguez, 1999; Contreras, 2014) se obtuvieron los hallazgos que se exponen más adelante, sobre la base de la proyección colectiva del audiovisual ya terminado. Esta dinámica permitió la realización de ejercicios de observación y reflexión en dos puestas en común: a) devolución del producto audiovisual a un grupo de autoridades locales de San Juan Atitán, con el fin explorar los sentimientos y respuestas colectivas; b) proyección ante actores instituciones a nivel nacional (especialmente del Ministerio de Cultura, Juventud y Deportes de Guatemala y la AGAAI), con el fin de reflexionar acerca de las iniciativas de cooperación, la conveniencia de incorporar herramientas audiovisuales y lograr compromisos sobre actividades futuras para la preservación y promoción del patrimonio cultural.

\section{Figura 2}

Devolución del audiovisual etnográfico "Los guardianes del tiempo" a autoridades locales del municipio de San Juan Atitán (Huehuetenango, Guatemala)

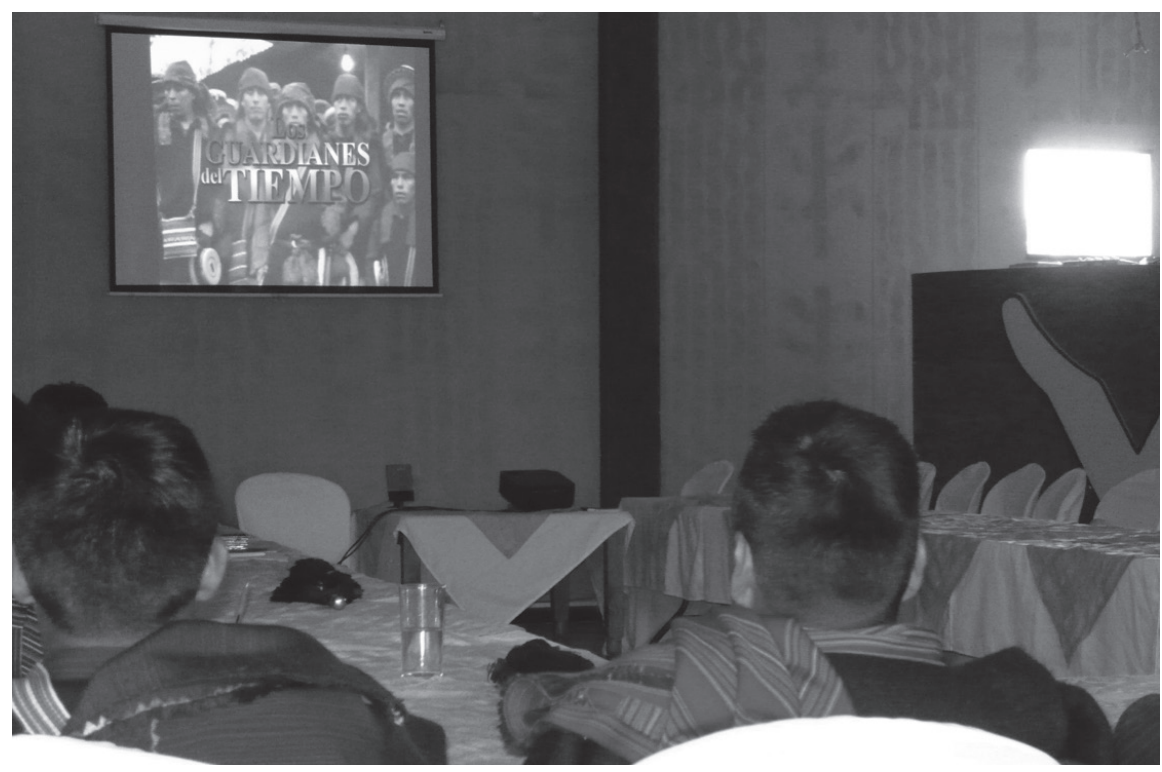




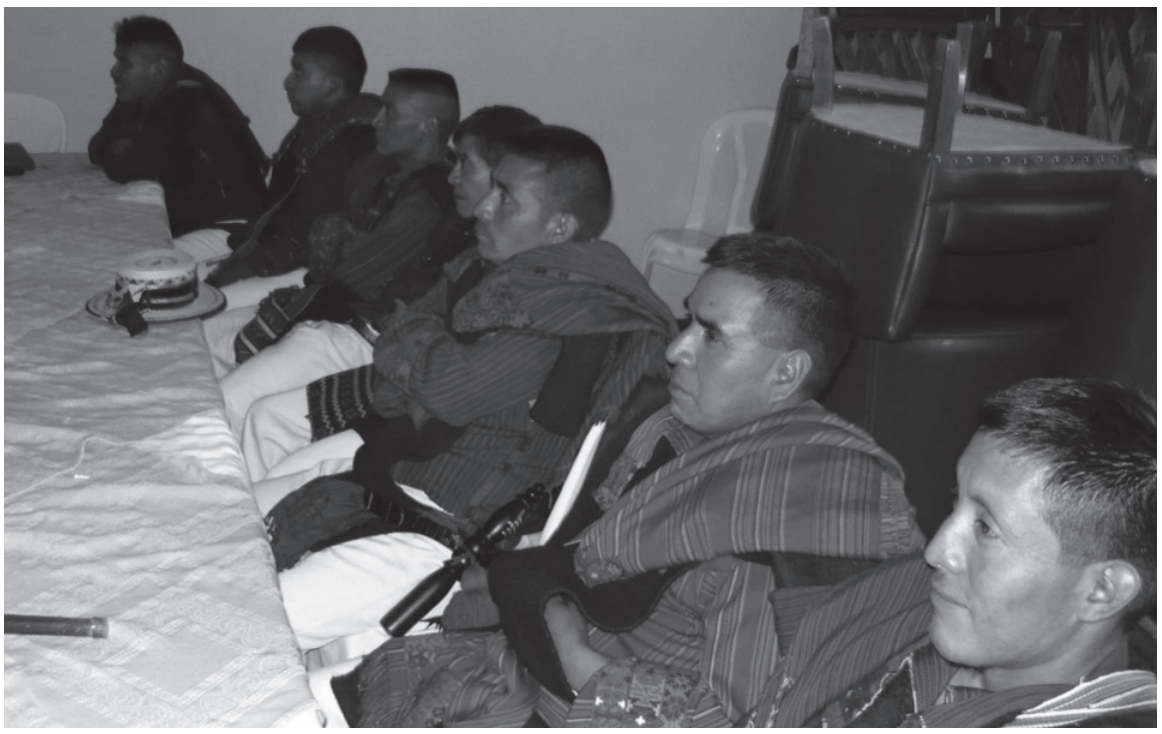

La actividad contó con la participación ordenada de los asistentes, quienes, a menudo, se expresaron en lengua mam, dada la dificultad de hablar en castellano. En este caso, dos personas hicieron las veces de traductores, por conocer bien el idioma español. A los participantes se les explicó el motivo de este trabajo en grupo, con intención de ser utilizado en una investigación de carácter cualitativo sobre la importancia del uso del audiovisual etnográfico para el fortalecimiento de la identidad cultural de la cultura mam que contribuyera a su desarrollo. Es importante reseñar que no todos los asistentes intervinieron de la misma forma. En la reunión era apreciable notar las diferencias culturales y las dificultades surgidas en torno a la emisión-recepción de los mensajes. Sin embargo, se estableció una interacción de gran riqueza dialéctica, que generó información importante conducente al establecimiento de una serie de conclusiones.

\section{Relato etnográfico}

A continuación, se expone un fragmento de un relato etnográfico propio del proceso de observación participante, llevado a cabo en el momento de la investigación y la grabación del producto audiovisual (trabajo de campo). Su forma es narrativa, como señala Angrosino (2012), un relato "cuya meta prin- 
cipal es involucrar al lector en una experiencia real de la comunidad en la que el etnógrafo ha vivido e interactuado" (p. 36). En él se incluye la interpretación del investigador respecto a los simbolismos de la tradición, en los que se pretende haber contribuido a una (re)construcción colectiva de sentidos culturales tendentes a fortalecer la identidad del municipio y contribuir al diálogo intercultural y, por tanto, a un desarrollo comunitario ordenado y con vocación sostenible. Para ello, la entrevista y la documentación bibliográfica se consideran elementos clave en la investigación. Se propone un relato etnográfico construido sobre la base de la invisibilidad del etnógrafo en el texto, aunque sea él quien finalmente configura su forma y contenido. Subyace en esta relación la visibilización de los hechos etnografiables que considera el investigador, prestando atención a los detalles, a los contrastes y a sus reflexiones personales, siempre desde una perspectiva de respeto hacia los otros:

La celebración se realiza los últimos días de noviembre, cuando en San Juan Atitán prevalece un clima de frío y niebla a ciertas horas de la jornada. A primera hora de la tarde, se nota un ambiente de fiesta. Es la víspera del momento en el que se repetirá la costumbre y se elegirán a las nuevas autoridades. Todo el pueblo está llamado a participar. Los regidores han preparado la lista y han presentado una propuesta al alcalde y los concejales. El centro de atención se sitúa en la Casa de Costumbre, una sencilla construcción de adobe y teja, junto a dos cobertizos que, en conjunto, forman una ' $U$ ' dejando una pequeña explanada en el centro. En el interior del edificio principal, el alcalde, los concejales y los regidores principales analizan las listas de los elegidos. Nadie en la comunidad conoce sus nombres. Las listas están escritas a mano y son objeto ahora de una cerrada y exhaustiva revisión, que dura varias horas. En el exterior, una rústica marimba, interpretada por tres músicos, ameniza la concentración progresiva de cientos de sanjuaneros que van llegando a la Casa de Costumbre y los promontorios aledaños, formando una marea de color. Las mujeres, ataviadas con su típico adorno de cintas rojas en la cabeza, lavan las ollas gigantes en las que prepararán comidas típicas en fuegos de leña. También traen flores, amarillas, rojas y blancas, que cumplirán un papel fundamental en la ceremonia. La espera se hace larga, por eso los allí concentrados meditan, conversan, incluso bailan al ritmo de los sones tradicionales. Han traído bebidas para todos. El ambiente es distendido, en medio de una jauría de voces en lengua mam.

Pasadas unas horas, se levanta la sesión. Ya están asignados los nombres de las casi doscientas nuevas autoridades para el año entrante. Salen los con- 
cejales y al final el alcalde. Se unen a ellos los regidores, mayores y guardabosques actuales. Todos, escrupulosamente ordenados en fila india, caminan hacia la municipalidad. Hacen sonar los silbatos mientras avanzan. El estrépito se pierde en la inmensidad de San Juan Atitán.

Cae la tarde y las luces de las aldeas comienzan a poblar tímidamente la montaña. Se presume una noche fría y larga. Prácticamente nadie va a dormir. Unos esperarán impacientes la resolución, otros poblarán las cantinas sin prometer nada acerca de sus efectos. El pronunciamiento será al amanecer. A las cuatro de la madrugada, la luna intenta abrirse paso entre la niebla. En la Casa de Costumbre, una abigarrada multitud espera ya en silencio la llegada del alcalde y su séquito. Forman un auditorio impresionante de miles de caras, cuyas quietas expresiones sólo se adivinan entre penumbras. Tímidamente empiezan a sonar las notas de la marimba, que se mezclan con los sonidos de los gallos y la explosión de algún que otro cohete. En la calle empinada que conduce hasta la Casa de Costumbre resuenan los silbatos, señal de que se acercan las autoridades. Las mujeres están agrupadas y comienzan a restallar las brasas que calentarán la comida para todos. El alcalde y los concejales se sientan en la mesa principal que han dispuesto en el patio. Las autoridades vigentes ocupan los asientos colocados en forma de U, pero antes, en fila india, dan varias vueltas hasta formar varios aros concéntricos. Es un rito improvisado, ensayado sólo en los cientos de años de costumbre, símbolo de los significados emanados del calendario maya y su concepción circular del tiempo. El calendario maya es considerado más exacto incluso que el sistema gregoriano, por el que nos regimos actualmente. La ronda calendárica o "cuenta larga" de los mayas es una combinación de, por un lado, el año civil, llamado haab por los mayas de Yucatán y masewal q’ij por los maya-quiché (Tedlock, 2002). Era un calendario solar de 365 días con 18 meses de 20 días y 5 días adicionales. Y por otro, el calendario sagrado, llamado tzoltin o cholq'ij, según el caso, que en total duraba 260 días.

Tedlock (2002) explica que el primer día del primer mes del calendario solar es llamado el Mam en varios idiomas mayas y marca el destino del resto del año. Los cuatro cargadores del año son Kej, E, No'j e Iq'. En el momento de nuestro relato etnográfico, I'q es el día clave para la elección de autoridades locales, que en este caso se combina con el día $A q^{\prime} a b^{\prime} a l$, propicio para elegir. Los dos alcaldes de costumbre han estado toda la noche realizando sus ceremonias, en torno al fuego sagrado, invocando al Corazón del Cielo y al Corazón de la Tierra para que ilumine a las nuevas autoridades. Al 
respecto, José Vicente, alcade de costumbre, indica: “I'q es un día adecuado para pedir todo lo bueno al ser supremo, para que él lo conceda. Por eso se escogen a las personas hoy. Aq'ab'al es el día propicio para nombrar, para hacer el llamado. Se combinan estos dos nawales para que todo el trabajo del nuevo gobierno durante un año salga de la mejor manera". Las primeras haces de luz se adivinan en el firmamento. Amanece. El silencio se rompe con la voz del alcalde, que se hace escuchar de forma metálica a través de un megáfono. Saluda en mam a los presentes. A continuación, le cede el micrófono al primer regidor, quien recita la lista de las nuevas autoridades en una implacable letanía que el auditorio asume guardando un silencio sepulcral.

Sólo el melancólico tintineo de la marimba se atreve a hacer ruido al término del nombramiento. El silencio se rompe. Poco a poco, la masa apretada en tonos morados, rojos y blancos empieza a moverse y los miles de sombreros de paja, vistos desde arriba, componen mosaicos desiguales. Circulan los tamales de maíz y el caldo de res que pacientemente han cocinado las mujeres para todos, algunas sin soltar a los niños, amarrados a sus espaldas.

¿Dónde están los elegidos? Algunos se han llevado la noticia hacia sus casas y ahora, con las manos debajo del capishay, cabizbajos, y de forma inadvertida, caminan por las enlodadas y estrechas calles para dialogar con sus mujeres. No va a ser fácil asumir la decisión. ¿De dónde obtener los ingresos durante un año para mantener a la familia? En el improvisado coloquio de un grupo de mames, nos han confesado que muchos se endeudan a través de empresas microfinancieras, que les ofrecen créditos blandos para que puedan afrontar el préstamo. ¿Y si se oponen al nombramiento? Es la última opción. No se puede atentar contra la costumbre.

Las flores son el testigo del poder, el símbolo de traspaso de autoridad. Son blancas, amarillas y rojas. Los ramilletes están amarrados por una cinta blanca adhesiva donde los regidores han escrito el nombre y el cargo de cada una de las nuevas autoridades. Luego los han colocado en cuatro grandes canastos, que deberá llevar a hombros cada uno de los cuatro regidores, desde la Casa de Costumbre hasta el palacio municipal. La estampa emula la imagen del cargador del año maya, ese nawal o signo calendárico que marca los destinos de cada año. Ahora, los cuatro cargadores de flores bajan por la cuesta principal, recordándonos la importancia del número 4 en la cosmovisión maya: lo pleno y universal, como el sol; cuatro son los puntos cardinales y sus colores. Junto al negro, son los mismos que las flores que sostienen: blanco, rojo y amarillo. Le siguen, de nuevo en una fila ordenada, los mayo- 
res, regidores y guardabosques. Todos ellos ahora son signos calendáricos, cada uno portando un nawal, un significado espiritual.

La procesión cobra un sentido profundamente sagrado y rememora los episodios de la creación del mundo que relata el texto sagrado del Popol Vuh. Los héroes gemelos de la "biblia maya", Hunapuh e Ixbalanqué, engañaron a los señores del Inframundo -Xibalbá-y los derrotaron, cargando en cuatro jícaras los ramos de color blanco, amarillo y colorado de una planta leguminosa llamada chipilín, que los mismos malignos les habían encargado:

Y llevando las flores en las cuatro jícaras, se fueron, y cuando llegaron a presencia del Señor y los demás Señores, daba gusto ver las flores que traían. Y de esta manera fueron vencidos los de Xibalbá (Recinos, 2006, p. 143).

Probablemente, los habitantes de San Juan Atitán hoy no son conscientes de la notoria carga mística del ceremonial. Aun así acuden a ver el cortejo camino al edificio municipal. Todos, vestidos con su traje típico, abarrotan la plaza. Mientras, en la sala consistorial, el alcalde arenga a las autoridades salientes. Son ellas las que, con su correspondiente ramo de flores, entregarán el testigo del poder a los nuevos mandatarios. Cada uno sale con su ramo en la mano para dirigirse a su lugar de destino. Irán a pie y no importa que sea un barrio, una aldea o una casa aislada. Algunos tardan hasta más de dos horas en llegar. Abajo, en la plaza, esperan sus más allegados para acompañarlos. El escenario se descompone en movimientos multicolores en torno a cada ramo. Los grupos se van dispersando en diferentes comitivas que emprenden su marcha. La mayoría de ellas discurren por el camino principal, apenas separadas por unos metros. En todas resuenan los silbatos, cuyos ecos se descuelgan a lo largo del valle. El ritmo es rápido y máxima la expectación a lo largo del recorrido, sobre todo por parte de las mujeres, porque los grupos de esta particular peregrinación están compuestos sólo por hombres. Hay improvisadas paradas por el camino, que sirven para refrescarse con una gaseosa e ingerir algo de comida. La jornada es larga. Empezó al amanecer y algunos la terminarán entrada la noche.

Cada autoridad saliente entrega el ramo a su sucesor. Después, la calle principal, en la ladera de la montaña, va cobrando lentamente la normalidad. La plaza se vacía de gente y de color. El pueblo cobra su imagen habitual, su sosiego y su silencio de cualquier día sin historia en el calendario. Desde el ocaso, vigila la tradición, con su imponente porte, el volcán Tajumulco. Resuenan más abajo las aguas del río Cuilco. Y, al amanecer, cuando el tiempo maya se renueve, las autoridades locales comenzarán un nuevo ciclo en San Juan Atitán. 


\section{Figura 3}

\section{Preparación de ramos de flores en San Juan Atitán, símbolo de traspaso de poder $^{5}$}

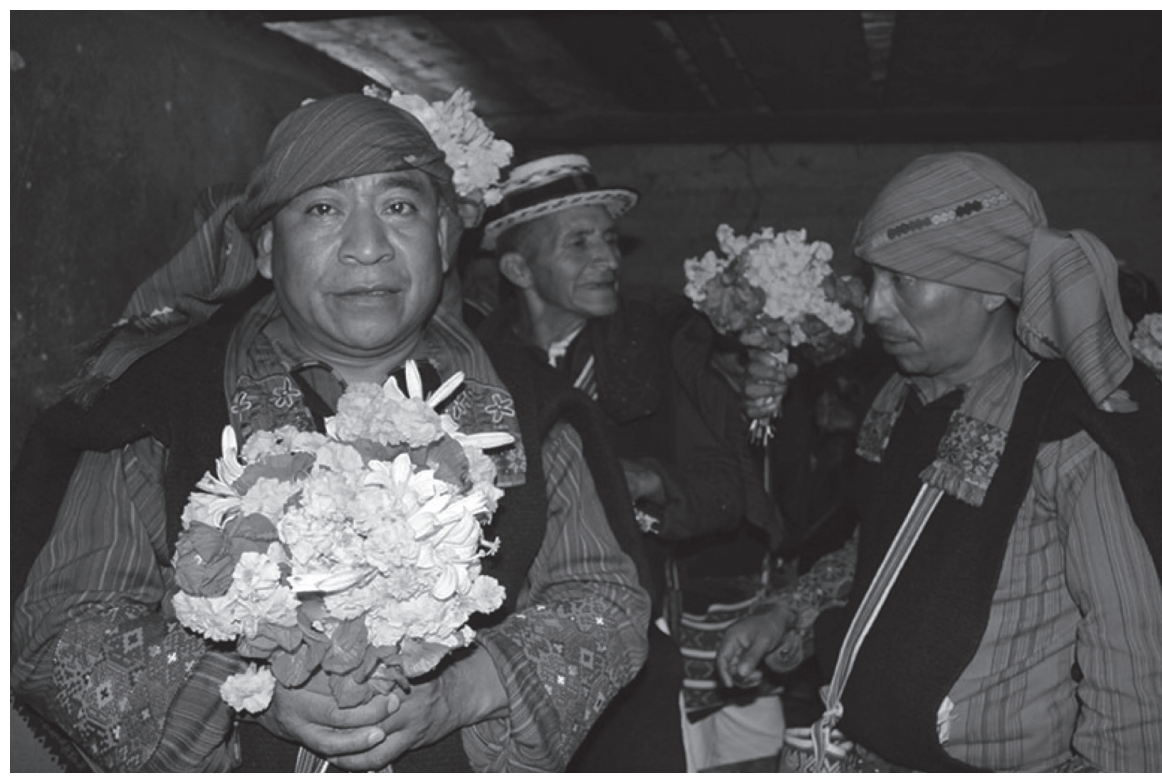

\section{Principales hallazgos}

En los distintos foros de devolución del audiovisual se intercambiaron y debatieron ideas, algunas de las cuales elevamos a la categoría de principales hallazgos en la presente investigación:

El audiovisual etnográfico visibiliza la participación de los pueblos indígenas. La diversidad cultural es una oportunidad para el desarrollo de países como Guatemala, y ésta a menudo pasa inadvertida. Pese al reconocimiento de dicha participación en los acuerdos de paz y otros foros internacionales, en numerosas ocasiones no se hace efectiva o, simplemente no se visibiliza. El audiovisual contribuye de esta manera a consolidar procesos hacia una demo-

5 Todas las fotografías han sido realizadas por Bruzón, L., autor de este artículo. 
cracia de calidad, mediante la participación comunidades indígenas, referentes clave en el diseño de las políticas públicas municipales.

La visibilización contribuye a la inclusión social, a poner en la superficie los numerosos patrimonios culturales que existen en medio de la diversidad y que a menudo nos son desconocidos. La documentación audiovisual basada en la investigación etnográfica y su visionado participativo estimula la reflexión crítica de la comunidad respecto a sus tradiciones y prácticas culturales, y la importancia de su sostenibilidad.

El audiovisual etnográfico fortalece la identidad cultural y la autoestima de los pueblos. Verse reflejados en imágenes supone, en primer lugar, una emoción para los protagonistas. La emoción les produce alegría, entusiasmo y les motiva al diálogo. Es un reconocimiento de la otredad de la que forman parte, la cual se convierte en un reconocimiento del yo (Grajeda, 2013). En general, aceptan las interpretaciones del etnógrafo respecto a los simbolismos de su cultura, a pesar del grado autoridad etnográfica del autor que pueda incorporar a través de su mirada subjetiva. No obstante, reconocen que el acercamiento respetuoso a la realidad en estudio es el correcto. De alguna manera se sienten "coproductores" e incluso "copropietarios" del video final (MacDougall, 1995). Se quejan de otros trabajos que, desde la investigación antropológica, han carecido del proceso de devolución del producto final. Por ejemplo, A. J., regidor, participante en el acto de devolución, indica:

Las interpretaciones son válidas y necesarias. Muchas veces la palabra tradición no va acorde con lo que la manifestación muestra. Es importante ir para atrás, investigar y hacer otras interpretaciones. Hacer relaciones con el pasado, con el calendario maya, es bueno, para poder entender qué significa la tradición para estos pueblos.

Por su parte, S. H., guardabosque, afirma: "El documental refleja la realidad. Es un recuerdo de lo que han dejado nuestros antepasados. Nos ha gustado la forma en la que narra el video, nos hemos visto reflejados". Se valora, en definitiva, la labor de mediación -no solo de documentación- del etnógrafo, hacia procesos de empoderamiento y cohesión social.

El audiovisual etnográfico es una herramienta de comunicación municipal. Los procesos de documentación y difusión de la tradición constituyen un valor agregado al diseño y ejecución de las políticas públicas municipales, pues propician espacios de participación y diálogo intercultural hacia la transformación social, la mejora de las condiciones de convivencia ciuda- 
dana y la transmisión intergeneracional de la cultura. F. V., guardabosques, afirma: "El video es una herramienta para el diálogo entre la comunidad y las autoridades y para estimular la tradición entre los jóvenes". La comunicación, por tanto, ha de formar parte de dichas políticas y, para ello, documentar y difundir la cultura es un elemento esencial.

\section{Conclusiones}

Al hilo de la investigación realizada, el audiovisual etnográfico puede ser una herramienta útil de comunicación estratégica para investigar, documentar, intepretar y difundir la tradición, entendida ésta como forma legítima de identidad de los pueblos y manifestación digna de consideración para procesos de refrendo a las políticas públicas comunitarias diseñadas y ejecutadas desde la legitimación de la gobernabilidad municipal. En el caso de las comunidades indígenas de Guatemala (y, por extensión de Centroamérica), golpeadas por la marginación y la desarticulación del tejido social por diversas causas a lo largo de la historia, el audiovisual etnográfico es un elemento de fortalecimiento de la autoestima, reconocimiento de la diversidad cultural y respeto a los derechos culturales de las personas, concebidos y aceptados por los organismos regionales como derechos humanos fundamentales. La labor del investigador desde el ámbito de la comunicación para la transformación social es clave en procesos de construcción colectiva. A ello habrá de contribuir una necesaria formación universitaria cada vez más especializada en el ámbito de la cultura y el desarrollo local (Bruzón \& Hernando, 2016), con el fin de ampliar su mirada hacia espacios de mediación y diálogo intercultural.

\section{Bibliografía}

Alzaga, B. R. (1998). Grupos de discusión. De la investigación social a la investigación reflexiva. En L. J. Galindo (Coord.), Técnicas de investigación en sociedad, cultura y comunicación (pp. 75-116). Estados Unidos: Addison Wesley Longman.

Angrosino, M. (2012). Etnografía y observación participante en investigación cualitativa. Madrid, España: Ediciones Morata.

Arévalo, J. M. (2004). La tradición, el patrimonio y la identidad. Revista de estudios extremeños, 60(3), 925-956. Recuperado de http://sgpwe.izt.uam.mx/files/users/uami/mcheca/GEOPATRIMONIO/LECTURA2E.pdf 
Bruzón, L. (21 de marzo de 2016). Los guardianes del tiempo. [Archivo de vídeo]. Recuperado de https://www.youtube.com/watch?v=9XPAECNrQds

Bruzón, L. \& Hernando, A. (2016). Un enfoque del audiovisual etnográfico hacia el desarrollo y la inclusión social de los pueblos indígenas y afrodescendientes de Centroamérica. Chasqui. Revista Latinoamericana de Comunicación, (129), 381-399. Recuperado de http://chasqui.ciespal.org/ index.php/chasqui/article/viewFile/2442/pdf

Cadenas, H. (2008). Antropología Posmoderna y Semiótica: El problema de la autoridad etnográfica. Revista de Estudios Interdisciplinarios ASOSYLFF, 2(2), 135-146. Recuperado de https://www.academia.edu/1516530/Antro polog\%C3\%ADa_Posmoderna_y_Semiótica_El_problema_de_la_auto ridad_etnográfica?auto=download

Cárdenas, C., \& Duarte, C. (2010). Etnografía audiovisual: Instrumento para la divulgación de un conocimiento y técnica de investigación social. Manuscrito inédito https://www.google.com/url?sa=t\&rct=j\&q=\&esrc=s\&sour ce=web\&cd=1\&ved=0ahUKEwjKmPTk_dDNAhUBFx4KHQnQB2 EQFgghMAA\&url=https\%3A\%2F\%2Fvertov14.files.wordpress.com $\% 2 \mathrm{~F} 2010 \% 2 \mathrm{~F} 08 \% 2 \mathrm{Fetnografia}-$ audiovisual.pdf\&usg=AFQjCNEae_ V0nr5xWC_ILiIwv7XCsv1fFw\&sig2=YokIqu-w-FvoqFVHTnIi4Q

Contreras, P. (2014). La alfabetización mediática como herramienta de intervención enprisiones (Memoriaparaoptaralgradodedoctorado).Recuperado http:// rabida.uhu.es/dspace/bitstream/handle/10272/7946/Alfabetizacion_ mediatica.pdf?sequence $=2$

Espinosa, J. A. (2012). El video participativo: herramienta para la transformación social en procesos pedagógicos, sociales y políticos: Diseño de propuestas para dos casos en la Península Ibérica. Revista Nexus Comunicación, 1(12), 64-75. Recuperado de http://nexus.univalle.edu.co/index.php/nexus/article/view/1782

Flores, C. Y. (2005). Video indígena y antropología compartida: una experiencia colaborativa con videastas maya-q'echi'de Guatemala. LiminaR: Estudios sociales y humanísticos, 3(2), 7-20. Recuperado de http://www.redalyc. org/articulo.oa? $\mathrm{id}=74530202$

García González, D. (2005). La cuestión municipal en Centroamérica: un desafio para la consolidación y la modernización del Estado. San José, Costa Rica: AECI-Fundación DEMUCA.

Geertz, C. (1987). Descripción densa: hacia una teoría interpretativa de la cultura. En C. Geertz (Autor), La interpretación de las culturas (pp. 19-40). Barcelona, España: Gedisa Editorial. 
Grajeda, D. (2013). Modular redes de conversaciones con actores clave para la integración regional: Estrategia de comunicación del PARLACEN 20132017. Guatemala: PAIRCAII/PARLACEN.

Grau, J. (2002). Antropología audiovisual: fundamentos teóricos y metodológicos en la inserción del audiovisual en diseños de investigación social. Barcelona, España: Ediciones Bellaterra.

Harris, M. (2001). Antropología cultural. España: Editorial Alianza.

Hawkes, J. (2001). The fourth pillar of sustainability: Culture's essential role in public planning. Australia: Common Ground Publishing.

Íñiguez, L. (1999). Investigación y evaluación cualitativa: bases teóricas y conceptuales. Atención Primaria, 23(8). Recuperado de http://www.elsevier. es/es-revista-atencion-primaria-27-articulo-investigacion-evaluacioncualitativa-bases-teoricas- 14823

Kapuscinski, R. (2014). Los cínicos no sirven para este oficio: Sobre el buen periodismo. Barcelona, España: Editorial Anagrama.

Lisón, J. C. (1999). Una propuesta para iniciarse en la Antropología visual. Revista de Antropología Social, (8), 15-35. Recuperado de https://revistas.ucm. es/index.php/RASO/article/viewFile/RASO9999110015A/10033

MacDougall, D. (1995). ¿De quién es la historia?. En E. Ardevol, \& L. Pérez (Eds.), Imagen y cultura: Perspectivas del cine etnográfico (pp. 401-422). Granada, España: Diputación Provincial de Granada.

Micelli, I. (2009). Experiencia etnográfica y lenguaje audiovisual: del informe escrito a la ficción etnográfica (Tesis de maestría, FLACSO). Recuperada de http://repositorio.flacsoandes.edu.ec/handle/10469/763\#.V3aPCZPhDeQ

Pulido, R., Ballén, M., \& Zúñiga, F. (2007). Abordaje hermeneútico de la investigación cualitativa: Teorías, procesos, técnicas. Bogotá, Colombia: Editorial Universidad Cooperativa de Colombia.

Ranocchiari, D. (2015). Creole: Inside. Cómo hacer filmaciones no etnográficas puede servir a la realización de una etnografía. Revista de Antropología Experimental, (15), 225-239. DOI: 10.17561/rae.v0i15.2615

Recinos, A. (2006). Popol Vuh: Las Antiguas Historias del Quiché. México: Berbera.

Santos, M. A. (1993). La evaluación: un proceso de diálogo, comprensión y mejora. Investigación en la Escuela, (20), 23-38. Recuperado de http://www. investigacionenlaescuela.es/articulos/20/R20_2.pdf

Tedlock, B. (2002). El tiempo y los mayas del altiplano. Fundación YAX TE'. Toffler, A. (1999). La Tercera ola. España: Plaza y Janés. 
UNESCO (2003). Convención para la Salvaguarda del Patrimonio Cultural Inmaterial. Recuperado de http://unesdoc.unesco.org/images/0013/001325/ 132540s.pdf

UNESCO. (2005). Convención sobre la Protección y la Promoción de la Diversidad de las Expresiones Culturales. Recuperado de http://www.iedf.org. $\mathrm{mx} / \mathrm{sites} / \mathrm{DDHH} /$ convenciones/17.pdf

Zirión, A. (2015). Miradas cómplices: cine etnográfico, estrategias colaborativas y antropología visual aplicada. Revista de Ciencias Sociales y Humanidades, (78), 45-70. Recuperado de http://148.206.53.234/revistasuam/ iztapalapa/include/getdoc.php?id=1809\&article $=1877 \&$ mode $=$ pdf

Fecha de recepción: 03/05/2017; fecha de aceptación: 31/07/2017;

fecha de publicación: 01/09/2017 



\title{
Adornos corporales y género en las fotografías etnográficas de Yámana/Yagán
}

\author{
Body ornaments and gender in the ethnographic \\ photographs of Yámana/Yagán
}

\author{
Ana Butto ${ }^{1}$ \\ anabutto@gmail.com \\ Danae Fiore ${ }^{2}$ \\ danae_fiore@yahoo.es
}

\begin{abstract}
Resumen
Este trabajo se propone discutir el aporte del estudio de las fotografías etnográficas acerca de los adornos corporales y las regulaciones de género de la sociedad Yámana/Yagán de Tierra del Fuego (Argentina y Chile). Se entiende a la fotografía como un artefacto cultural que permite rescatar múltiples agencias, considerando que los elementos incluidos en la imagen -como los adornos corporales- refieren no sólo a los intereses del fotógrafo sino también a los de los fotografiados. A fin de analizar esos elementos, se estudiaron 428 fotografías etnográficas de Yámanas/Yaganes, obtenidas entre fines del siglo XIX y comienzos del XX; se seleccionaron 140 individuos fotografiados que portaban un total de 171 adornos corporales entre collares, brazaletes y/o tobilleras. Se analizó el vínculo entre tipo de adorno y género de su portador, y se encontró que los collares fueron usados tanto por mujeres como por varones, mientras que brazaletes y tobilleras lo fueron por mujeres. Estos resultados permiten discutir el rol de los adornos en la construcción y regulación de roles de género en la sociedad Yámana/Yagán. Simultáneamente se evalúa el aporte de las fotografías etnográficas como artefactos de cultura material que, mediante la combinación de una mirada antropológica y arqueológica, resultan relevantes para producir nuevos conocimientos sobre el pasado indígena.
\end{abstract}

\section{Palabras clave}

Fotografía, indígena, Yámana, adorno corporal, género, artefacto.

Forma sugerida de citar: (2017). Butto, Ana, \& Fiore, Danae (2017). Adornos corporales y género en las fotografías etnográficas de Yámana/Yagán. Universitas, XV(27) pp. 67-92.

1 Dra. en Arqueología, Consejo Nacional de Investigaciones Científicas (CONICET), Asociación de Investigaciones Antropológicas (AIA) y Universidad Nacional de La Matanza (UNLaM), Argentina. Orcid: 0000-0001-7455-909.

2 Dra. en Arqueología, Consejo Nacional de Investigaciones Científicas (CONICET), Asociación de Investigaciones Antropológicas (AIA) y Universidad de Buenos Aires (UBA), Argentina. Orcid: 0000-0003-1672-3070. 


\begin{abstract}
This work aims to discuss the contribution of the study of ethnographic photographs about the body adornments and the gender regulations of the Yámana/Yagán society of Tierra del Fuego (Argentina and Chile). Photography is understood as a cultural artifact that allows the rescue of multiple agencies, considering that the elements included in the image -such as body ornaments-refer not only to the interests of the photographer but also to those of the photographed. In order to analyze these elements, 428 ethnographic photographs of Yamanas/Yaganes, obtained between the end of the 19th century and the beginning of the 20th century, were studied; of which 140 individuals were photographed carrying a total of 171 body ornaments between necklaces, bracelets and/or anklets. The link between type of ornament and gender of its wearer was analyzed, and it was found that necklaces were worn by both women and men, while bracelets and anklets were worn by women. These results allow us to discuss the role of body ornaments in the construction and regulation of gender roles in Yámana/Yagán society. Simultaneously, the contribution of ethnographic photographs as artifacts of material culture is evaluated, which, by combining an anthropological and archaeological perspective, are relevant to produce new knowledge about the indigenous past.
\end{abstract}

\title{
Keywords
}

Photography, indigenous people, Yámana, body ornament, gender, artifact.

\section{Introducción}

Este trabajo se propone discutir cómo la antropología audiovisual y, específicamente, el estudio de las fotografías etnográficas permite comprender el rol que cumplen los adornos corporales usados por los pueblos indígenas en la construcción y regulación de roles de género (Claassen, 1992; Conkey y Gero, 1991; Butler, 2004). El caso que analizaremos es el de la sociedad Yámana/Yagán, cuyo territorio ancestral ${ }^{3}$ abarca el sur del archipiélago de Tierra del Fuego (Argentina y Chile), concentrándonos en la forma en que mujeres y varones vistieron los adornos corporales -collares, brazaletes y tobilleras-.

3 Existen documentos que demuestran que el nombre yagán fue adoptado por esta sociedad a fines del siglo XIX, pero no se cuenta con información para tiempos anteriores (Piana en Fiore y Varela, 2009). 
Entendemos que las fotografías etnográficas son índices de una realidad tanto representada como reproducida mediante la captura de la luz y de los referentes ubicados frente al dispositivo fotográfico, por lo que no sólo reflejan la visión del productor de la imagen, sino que el referente real también aporta a su representación (Fiore y Varela, 2009). De esta manera, consideramos que es posible rescatar información acerca de los indígenas fotografiados y, en este caso, acerca del uso de sus adornos corporales. En este trabajo retomamos el concepto de género como una construcción del cuerpo sociocultural e históricamente situada, que implica características físicas y comportamentales que incluyen y exceden al sexo, orientando el desarrollo de elementos como apariencia física, postura, movimiento/gesticulación, tonos del habla, modos de vestimenta y ornamentación, generando un rol social individual pero emergente de la interacción con otros individuos (Conkey y Spector, 1984; Claassen, 1992; Sørensen, 2000). Por lo tanto, entendemos que los adornos corporales indígenas participaron en dicha construcción de géneros en las sociedades indígenas fueguinas (Fiore, 2007).

Por ello, centramos nuestro estudio en un total de 428 fotografías etnográficas de la sociedad Yámana/Yagán, obtenidas entre fines del siglo XIX y comienzos del XX, prestando especial atención a los individuos que portaban adornos corporales. De esa muestra, se seleccionaron 86 fotografías que retrataron a 140 individuos, que usan un total de 171 adornos corporales -124 collares, 20 brazaletes y 27 tobilleras-, los cuales fueron analizados especialmente a partir del género de su portador. A partir de esas variables de análisis, esperamos discutir el rol de los adornos en las construcciones y regulaciones de género de la sociedad Yámana/Yagán, así como el aporte de las fotografías etnográficas y la antropología audiovisual a la hora de conocer esas regulaciones de género (sensu Butler, 2004).

\section{Caso de estudio y estado de la cuestión}

Los Yámana/Yagán son un pueblo originario cuyo modo de vida tradicional fue cazador-recolector-pescador con movilidad canoera, que ocupó la porción sur de la Isla Grande de Tierra del Fuego y las islas del archipiélago fueguino hasta el Cabo de Hornos (Orquera y Piana, 2015). Los ancestros de los Yámana/Yagán habitaron dicho territorio desde los 7300 años AP cal 
-antes del presente ${ }^{4}$ - (Orquera y Piana, 1999). Su subsistencia se basaba en la caza de lobos marinos, guanacos y aves, la pesca de peces y la recolección de moluscos, además del aprovechamiento ocasional de ballenas varadas (Gusinde, 1986 [1937]; Orquera y Piana, 1999). Para el aprovechamiento de estos recursos desarrollaron una tecnología de movilidad y captura de presas específica: las canoas, los arpones y otras armas arrojadizas que facilitaban los traslados y el transporte, así como la captación de recursos imprescindibles (Orquera y Piana, 2015). Los campamentos, constituidos por chozas de troncos, ramas y hojas, eran habitados por grupos familiares. Ocasionalmente se daban reuniones de grandes grupos, por el varamiento de una ballena o para celebrar los ritos de iniciación a la adultez mixtos -chiéjausy masculinos -kina- (Gusinde, 1986 [1937]). Los viajeros que entraron en contacto con este grupo étnico desde el siglo XVII señalaron la ausencia de jefes o de figuras con una autoridad real (Fitz Roy, 1839). La división sexual del trabajo era semi-igualitaria, ya que la distribución de las tareas femeninas y masculinas era complementaria (Gusinde, 1986 [1937]; Fiore, 2007).

Muchos de los viajeros que entraron en contacto con los Yámana/Yagán señalaron el uso de adornos corporales (Fitz Roy, 1839; Hyades y Deniker, 2007 [1891]; Bridges, 2005 [1948]; Gusinde, 1986 [1937]). La pintura facial y corporal ${ }^{5}$ es mencionada por la mayoría de los viajeros, así como el uso de collares, brazaletes y tobilleras por parte de todos los grupos de edad (Martial, 2007 [1888]). Las diademas de plumas ${ }^{6}$, utilizadas en las ceremonias, fueron observadas por menos viajeros (Gusinde, 1986 [1937]). Junto con los viajeros, que a partir del siglo XVII comenzaron las exploraciones del territorio fueguino, llegaron nuevos artefactos y materias primas, entre ellos, collares y brazaletes de cuentas europeas que fueron adoptados por los Yámana/Yagán (Orquera y Piana, 2015).

4 En arqueología, los fechados radiocarbónicos se presentan como años AP "antes del presente", contabilizando la fecha desde 1950 hacia el pasado.

5 La pintura facial retratada en las fotografías etnográficas de Yámana/Yagán ha sido ampliamente estudiada por Fiore (2002) y no será abordada en este trabajo.

6 Las diademas de plumas usadas en las distintas ceremonias serán el foco de otro trabajo, y no serán abordadas en este artículo. 


\section{Figura 1}

\section{Mapa de Patagonia y Tierra del Fuego y ubicación del territorio ancestral de los Yámana/Yagán}

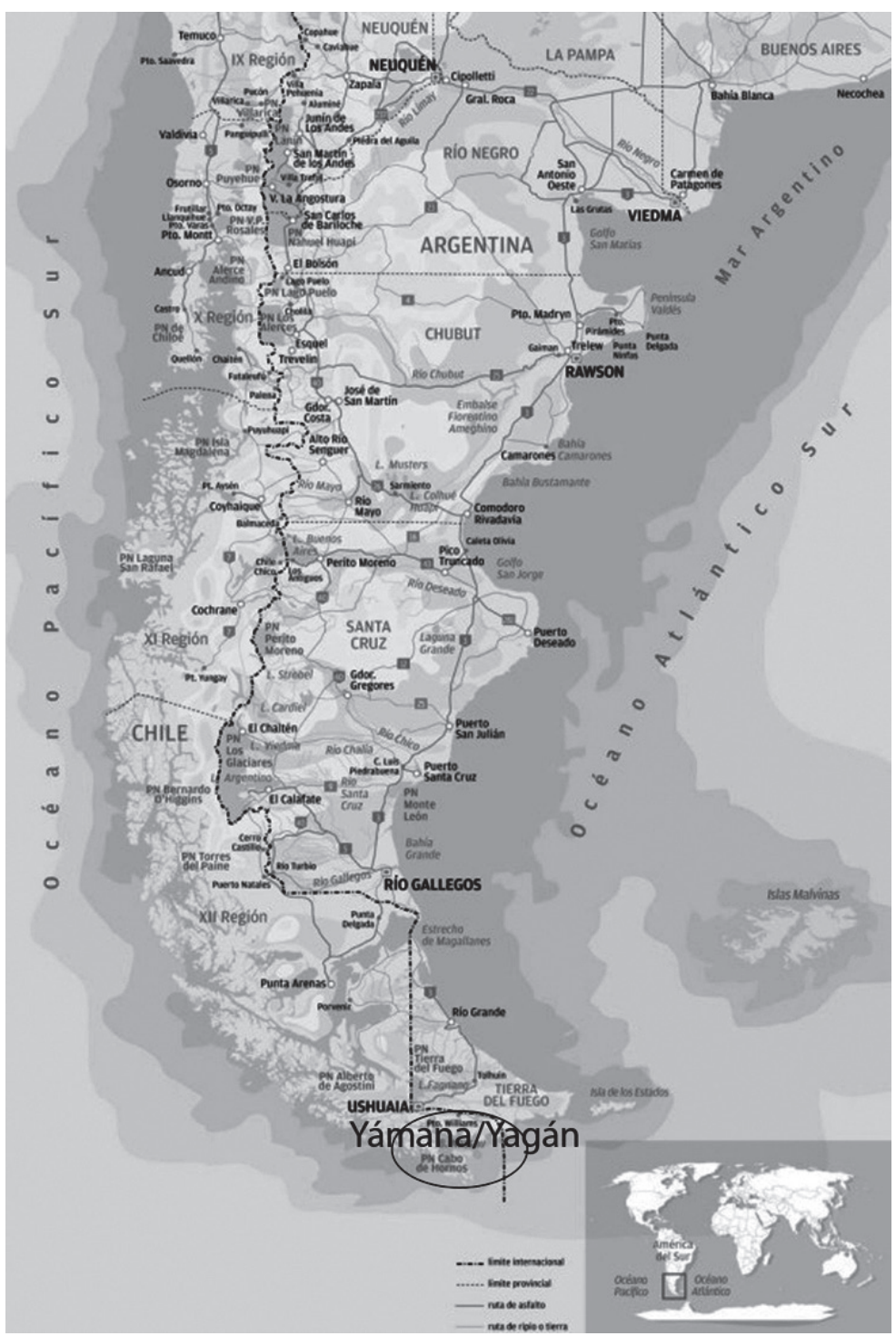

Fuente del mapa: www.patagoniatravelfinder.com 
Debido a la atracción que ejerció este pueblo originario fueguino, por ser considerado una "supervivencia" de un modo de vida pasado que se extinguía o como especímenes exóticos contemporáneos (Gusinde, 1986 [1937]; Penhos, 2005), existe un amplio corpus de fotografías de los Yámana/Yagán. Éstas han sido estudiadas por investigadores de múltiples disciplinas, centrados usualmente en tres elementos: la representación, la circulación y el referente representado.

Los estudios centrados en la representación enfatizaron en la forma en que los fotógrafos produjeron imágenes que se condicen más con su imaginario de lo salvaje que con la realidad de las poblaciones indígenas, para lo cual manipularon recursos y dispositivos (Alvarado, 2007; Edwards, 1992). Entre esas múltiples manipulaciones resalta la imposición de la desnudez, que se vuelve patente en cinco retratos tomados a una mujer Yámana/Yagán por los fotógrafos de la Misión Científica Francesa al Cabo de Hornos -instalada en la región entre 1882 y 1883-, en la que las poses de la joven dejan entrever la clara intención erótica de los fotógrafos (Carreño, 2002). Por otro lado, las manipulaciones de la vestimenta pueden ser clasificadas en tres tipos: la "vestidura" que resalta la vestimenta autóctona fueguina, para lograr una correspondencia exacta entre sujeto indígena, indumentaria tradicional y escenario natural; la "investidura" que implicaba la imposición de indumentaria occidental, para presentar a los fueguinos como seres pulcros y ordenados, capaces de ser incorporados a la civilización; y el "despojo" de algunos indígenas vestidos con restos de indumentarias occidentales, mostrándolos como seres desposeídos (Alvarado y Mason, 2005). Otro tipo de manipulación es la que recrea ambientes naturales, escondiendo el cautiverio de grupos fueguinos exhibidos en ferias internacionales y zoológicos humanos, a fin de "crear la ilusión de un ambiente <natural〉" (Báez y Mason, 2006, p. 56) acorde al imaginario acerca de las poblaciones indígenas.

Otros enfoques subrayan la circulación social e institucional de estas imágenes de indígenas fueguinos y enfatizan en su difusión como parte de manuales escolares. Las imágenes de indígenas fueguinos incluidas en los manuales escolares chilenos acentúan su desnudez, precariedad y primitivismo, a la vez que construyen una identidad fueguina arbitraria, al realizar adscripciones étnicas erróneas (Báez, 2005). Del lado argentino, las imágenes de fueguinos publicadas en los manuales escolares obedecen a dos tendencias: una que muestra una imagen prístina de los pueblos indígenas vistiendo y manipulando sólo elementos autóctonos y otra que los muestra 
como seres incorporados al Estado-nación, manipulando elementos occidentales (Saletta, 2011). En ambos casos, la fotografía es utilizada como si se tratara de una representación fidedigna del pasado, pero no como documento de los procesos de transculturación vividos por estos grupos desde fines del siglo XIX.

La concepción de la fotografía como un artefacto de cultura material socialmente construido, que aporta información sobre el fotógrafo y el fotografiado, permitió recuperar y analizar información acerca de los referentes representados (Edwards, 1992; Fiore y Varela, 2009). Esta postura entiende que no todos los elementos de una imagen responden a imaginarios y estrategias desplegadas por los fotógrafos, sino que la fotografía permite la inclusión de la materialidad cotidiana que escapa a la mirada del colonizador y que, por representar lo rutinario (Giddens, 1995), informa acerca de las prácticas culturales propias de estos pueblos (Fiore, 2005; Fiore y Varela, 2009; Butto, 2016). En esta línea de investigación se han estudiado comparativamente las fotografías de pinturas corporales de Yámana/Yagán y Shelk'nam, que evidenciaron distintos usos de la pintura corporal como elementos que producen identidades y divisiones sociales, como formas de ejercer el poder y de construir roles de género (Fiore 2005, 2007). A su vez, al estudiar la cultura material manipulada en las fotografías por las tres sociedades fueguinas -Shelk’nam, Yámana/Yagán y Alakaluf/Kawésqar- se encontró que cada sociedad produjo y manipuló distintos tipos de artefactos y que la adopción de cultura material foránea fue distinta en cada caso, porque los procesos de contacto con la sociedad occidental difirieron de acuerdo a los agentes occidentales enfrentados (militares, misioneros religiosos, etc.) y a los valores y prácticas de cada sociedad indígena (Fiore, 2007; Fiore y Varela, 2009; Butto, 2016). Estos estudios de los sujetos representados en las fotografías etnográficas de Yámana/Yagán demuestran que es posible identificar y evaluar las pautas de manipulación de cultura material y el género de los propios sujetos fotografiados. En el caso que nos ocupa, nos concentraremos en el vínculo entre ornamentos corporales y roles de género.

\section{Conceptos y métodos: fotos, género y ornamentos}

La fotografía fue entendida, en sus comienzos, como una analogía directa de la realidad, ya que su obtención mecánica implicaba un carácter supues- 
tamente objetivo (Bazin, 1960). El foco en el modo mecánico de producción de la imagen fotográfica permitía pensarla como una impresión, porque su procedimiento era el de la transferencia (Costa, 1991). De esta manera, la fotografía fue considerada como transparente y como un "mensaje sin código" (Barthes, 2004), que proveía "el testimonio visual y material de los hechos a los espectadores ausentes de la escena" (Kossoy, 2001, p. 30). Esta capacidad de registro objetivo convirtió a la fotografía en una gran herramienta de documentación para los primeros etnógrafos -junto con la escritura y la grabación de sonido-, ya que permitía perpetuar evidencias de su trabajo de campo (Collier, 1995; Grimshaw, 2001). Así, la fotografía permitía obtener una memoria detallada y genuina de esos "otros" estudiados y los acontecimientos vividos durante el trabajo de campo, ayudando a la consolidación de la antropología como una disciplina profesional (Naranjo, 2006).

Pero para los teóricos posmodernos la objetividad de las imágenes técnicas fue una ilusión, ya que la fotografía es siempre simbólica (Flusser, 1990). La fotografía adquiriría distintos significados según las circunstancias sociales y culturales, revelando la relatividad, ambigüedad y mutabilidad de su identidad. Así, su significado dependería de una práctica discursiva sumergida en relaciones de poder-saber, cuyas interpretaciones dependen de los usos $\mathrm{y}$ funciones de ciertas instituciones que han definido el estatus de la fotografía (Bourdieu, 1979; Tagg, 2005). A partir de esta idea de que el dispositivo fotográfico es siempre un dispositivo culturalmente codificado (Sekula en Batchen, 2004), la antropología comenzó a repensar el papel que jugó la fotografía dentro de las políticas de representación de la alteridad, enfatizando en las construcciones visuales del colonialismo (Scherer, 1995). Así, la antropología visual centró su análisis en las fotografías históricas como productos culturales coloniales que crearon y reprodujeron arquetipos populares de "lo exótico" entendido como lo culturalmente diferente (Naranjo, 2006).

Desde una postura "crítica", algunos teóricos han retomado la concepción de la fotografía como índice de la realidad representada, pero simultáneamente construida por los sesgos de sus productores. Estos autores destacan la conexión física entre el referente representado y la imagen fotográfica, entre el objeto y el signo visual que emana de aquél (Peirce, 1995). La singularidad del índice fotográfico se debe a que, si esa imagen es la huella lumínica de un objeto real que ha estado allí, entonces se trata de una marca única e irrepetible de ese sujeto/objeto. Así, aunque las imágenes fotográficas puedan reproducirse técnicamente (Benjamin, 2015) y puedan manipularse me- 
diante numerosos procesos de edición (Kossoy, 2001), el negativo que captó originalmente al referente es tan único como el propio referente. De esta manera, la fotografía remite a la existencia de ese referente real, convirtiéndose en evidencia, en testimonio de esa realidad representada (Freund, 2015). Esta idea de índice es la base para comprender la situación referencial de la fotografía, ya que la copresencia entre fotógrafo, cámara y fotografiado sólo se da durante el acto fotográfico, pero evidencia dicho contacto por un lapso mayor: el tiempo de vida de la fotografía como artefacto de cultura material (Dubois, 2008; Fiore y Varela, 2009). La concepción de las fotografías como "artefactos socialmente construidos que nos cuentan algo sobre la cultura reflejada así como la cultura del que toma dichas imágenes" (Ruby, 1996, p. 1346) permite desarrollar una arqueología visual que rescate tanto la agencia del fotógrafo como la del fotografiado (Fiore y Varela, 2009). Entendemos que en el "instante infinito" (Dubois, 2008) en que fotógrafo y referente se encuentran para realizar la toma fotográfica se da un "encuentro de subjetividades" (Fiore, 2005) que está sujeto a los diferentes grados de libertad de cada uno de los individuos: fotógrafo y fotografiado. Es innegable que los fotógrafos tienen mayor libertad de acción y poder de decisión sobre la imagen, ya que controlan más estadios de su producción: manejan el dispositivo fotográfico, su revelado y positivado y eventualmente su circulación -aunque ésta puede escapar a su control- (Poole, 2002).

Sin embargo, es también innegable que la presencia y agencia del sujeto fotografiado son imprescindibles para que ocurra la captura fotográfica; en otras palabras, sin referente real no hay fotografía. Así, aunque el grado de libertad sea siempre mayor en los grupos que detentan el poder, es decir, en los fotógrafos, esta distinción no anula el margen de injerencia de los sujetos fotografiados respecto de su propia representación. Consideramos entonces que en la producción de toda imagen fotográfica operan tanto el productor como el referente representado, con diferentes grados de pregnancia en la imagen fotográfica y es en esa relación diálógica en la que se construye la imagen (Butto, 2016). Por lo tanto, es posible captar tanto la visión del fotógrafo como la agencia del sujeto fotografiado, desde una perspectiva teórica en la cual ambos son individuos activos durante la toma fotográfica y pueden grabar su propia impronta e intereses en pugna. De esta manera, a pesar de los sesgos del fotógrafo, del editor, del curador y del archivador, la agencia del sujeto fotografiado está allí, esperando ser descubierta. Así, entendemos que la antropología audiovisual puede encontrar en la arqueología 
visual (sensu Fiore y Varela, 2009) un aliado que permite rescatar el valor de las fotografías etnográficas, que documentan el pasado reciente de las poblaciones indígenas.

Para desarrollar una arqueología visual de los ornamentos corporales de la sociedad Yámana/Yagán, seleccionamos una muestra total de 428 fotografías etnográficas obtenidas entre 1882 y 1971 por un mínimo de 25 fotógrafos conocidos -además de otros anónimos-. La conformación de esta muestra implicó la búsqueda, identificación y selección de fotografías de indígenas yámana/yagán en diversos archivos y publicaciones. La adscripción étnica de los sujetos fotografiados se realizó sobre la base de varios criterios complementarios: a) la adscripción por parte del archivo, b) los epígrafes de los fotógrafos, c) la cultura material manipulada por los sujetos fotografiados, d) el paisaje y e) el aspecto físico de los indígenas fotografiados.

Estas fotografías fueron analizadas en otros trabajos de acuerdo a la información visible en tres niveles (Fiore y Varela, 2009; Butto, 2016):

a. el nivel de la fotografía, evaluando los procesos de formación del registro fotográfico: fotógrafo/a, propósitos, lugares visitados, tiempo de estadía, vínculos con las personas fotografiadas, tipos de toma, adscripción étnica de las personas fotografiadas y contexto fotografiado;

b. el nivel de los individuos fotografiados: género, edad, rol social y nombre de cada persona;

c. el nivel de los artefactos fotografiados: tipos de choza, vestimenta, ornamentos, objetos.

Para este trabajo seleccionamos 86 fotografías, en que se retratan 140 individuos que usan adornos corporales como collares, brazaletes y tobilleras. Esos individuos retratados fueron analizados de acuerdo a su género y al tipo de ornamento/s usado/s, a fin de discutir si existían ornamentos exclusivamente femeninos, exclusivamente masculinos o compartidos por ambos géneros. Debido a que el proceso social de construcción del género se despliega mediante prácticas de uso de ornamentos corporales (Conkey y Spector, 1984; Conkey y Gero, 1991; Fiore, 2007), que construyen el rol de género del sujeto portador tanto en su auto-percepción como en la percepción por otros, el análisis del vínculo entre personas y ornamentos resulta especialmente relevante para conocer estas prácticas. Asimismo, el hallazgo de tendencias recurrentes sugiere la existencia de regulaciones de géne- 
ro (sensu Butler, 2004) que habrían funcionado en esta sociedad indígena. Cabe acotar que el análisis propuesto opera mediante una clasificación dicotómica de géneros: masculino y femenino, sin que ello implique que dicha dicotomía operase taxativamente en la sociedad Yámana/Yagán. Sin embargo, dado que existen indicios muy sutiles de variedades intra-género o categorizaciones de género por fuera de dicha dicotomía, ella resulta relevante para plantear un panorama inicial sobre este tema (Fiore, 2007).

\section{Adornos corporales en mujeres y varones Yámana/Yagán}

El primer análisis a realizar a esta muestra de 428 fotografías etnográficas de Yámanas/Yaganes es la cantidad de individuos fotografiada. Dado que la fotografía registra los individuos que posaron frente al dispositivo fotográfico, es posible registrar una "población fotografiada" y a partir de ella construir una "demografía fotográfica" (Fiore y Varela, 2009). Esta estructura demográfica fotografiada diferirá de la demografía real, en tanto que una misma persona puede ser contabilizada varias veces (todas las que fue fotografiada). Lamentablemente, no existen datos suficientes que permitan construir una demografía real, ya que en los primeros tres Censos Nacionales solo se contabilizó la cantidad aproximada de indígenas que habitaban los Territorios Nacionales ${ }^{7}$. Así, aunque no pueda ser comparada con una demografía real, esta demografía fotográfica aporta un interesante panorama sobre "la composición poblacional de los grupos fotografiados, y por extensión, de la población nativa contactada por los occidentales" (Fiore y Varela, 2009, p. 199).

De los 1574 individuos Yámana/Yagán retratados, más de la mitad eran varones $(52 \%, \mathrm{~N}=820)$, menos de la mitad eran mujeres $(45 \%, \mathrm{~N}=711)$ y algunos individuos no pudieron ser identificados en cuanto al género $(\mathrm{N}=43)$. En esta muestra encontramos un total de 171 ornamentos corporales usados por 140 individuos: 124 collares, 20 brazaletes y 27 tobilleras.

Los collares usados por los Yámana/Yagán fueron mencionados por la mayoría de los viajeros que entraron en contacto con ellos (Fitz Roy, 1839;

7 Pero existen otros datos confiables: Thomas Bridges estimó 2 500, 3000 personas yámana/yagán para tiempos anteriores a 1880, de las que en 1884 sobrevivían poco más de 1000 . Para el momento que Gusinde visitó Tierra del Fuego (1920) los Yámana/Yagán eran 73, 74. Ver más datos en Orquera y Piana, 2015. 
Hyades y Deniker, 2007 [1887]; Bridges, 2005 [1948]; Gusinde, 1986 [1937]). Los collares pueden ser caracterizados y clasificados de acuerdo a su morfología y materia prima, las cuales permiten deducir su carácter autóctono o foráneo. Los collares autóctonos usados por los Yámana/Yagán eran de tres tipos: 1) de valva de caracol agujereadas enhebradas en cuerdas $^{8}$,2) de huesos de ave también enhebrados en cuerdas y 3 ) de cuero o tripa trenzada (Fitz Roy, 1839; Hyades y Deniker, 1887; Gusinde, 1937 y otros autores citados en Orquera y Piana, 2015, pp. 320-325). A partir de la llegada de exploradores, científicos y misioneros al territorio fueguino los Yámana/Yagán adoptaron elementos occidentales en sus collares, tales como: cuentas de vidrio, botones, fragmentos de vidrio, cerámica o hierro (Orquera y Piana, 2015, p. 325). En las fotografías analizadas solo aparecen algunos tipos de collares (Tabla 1): entre los autóctonos aparecen los collares de hueso (Figura 2), de caracoles (Figura 3) y de cuero, mientras entre los foráneos aparecen los collares de cuentas $^{9}$ de distintos colores -blancas, oscuras y una mezcla de ambas- (Figura 4) y cuentas de metal. Encontramos que la mayoría de los collares fotografiados son foráneos $(94 \%)$, mientras la minoría (6\%) son autóctonos.

Tabla 1

Tipos de collares por género

\begin{tabular}{|l|c|c|c|c|c|c|c|c|}
\hline \multirow{2}{*}{$\begin{array}{c}\text { Tipo de } \\
\text { collares/ } \\
\text { Género }\end{array}$} & \multicolumn{3}{|c|}{ Autóctonos } & \multicolumn{4}{c|}{ Foráneos } & Total \\
\cline { 2 - 8 } & hueso & caracoles & cuero & $\begin{array}{c}\text { cuentas } \\
\text { blancas }\end{array}$ & $\begin{array}{c}\text { cuentas } \\
\text { oscuras }\end{array}$ & $\begin{array}{c}\text { cuentas } \\
\text { blancas } \\
\text { y oscuras }\end{array}$ & $\begin{array}{c}\text { cuentas } \\
\text { de metal }\end{array}$ & \\
\hline Mujeres & 1 & 2 & - & 17 & 20 & 41 & 1 & 82 \\
\hline Varones & - & - & 4 & 8 & 16 & 14 & - & 42 \\
\hline Total & 1 & 2 & 4 & 25 & 36 & 55 & 1 & 124 \\
\hline
\end{tabular}

Elaboración: Autoras

8 Las cuerdas eran confeccionadas a partir de tendones de ballena, tripa trenzada, fibras retorcidas o cuero (Orquera y Piana, 2015, p. 323).

9 Posiblemente se trate de cuentas de vidrio, pero no es posible verificarlo a partir de las fotografías consultadas. 


\section{Figura 2}

Mujer yámana/yagán, llamada Peine, con pintura corporal ceremonial y vistiendo un collar de huesos

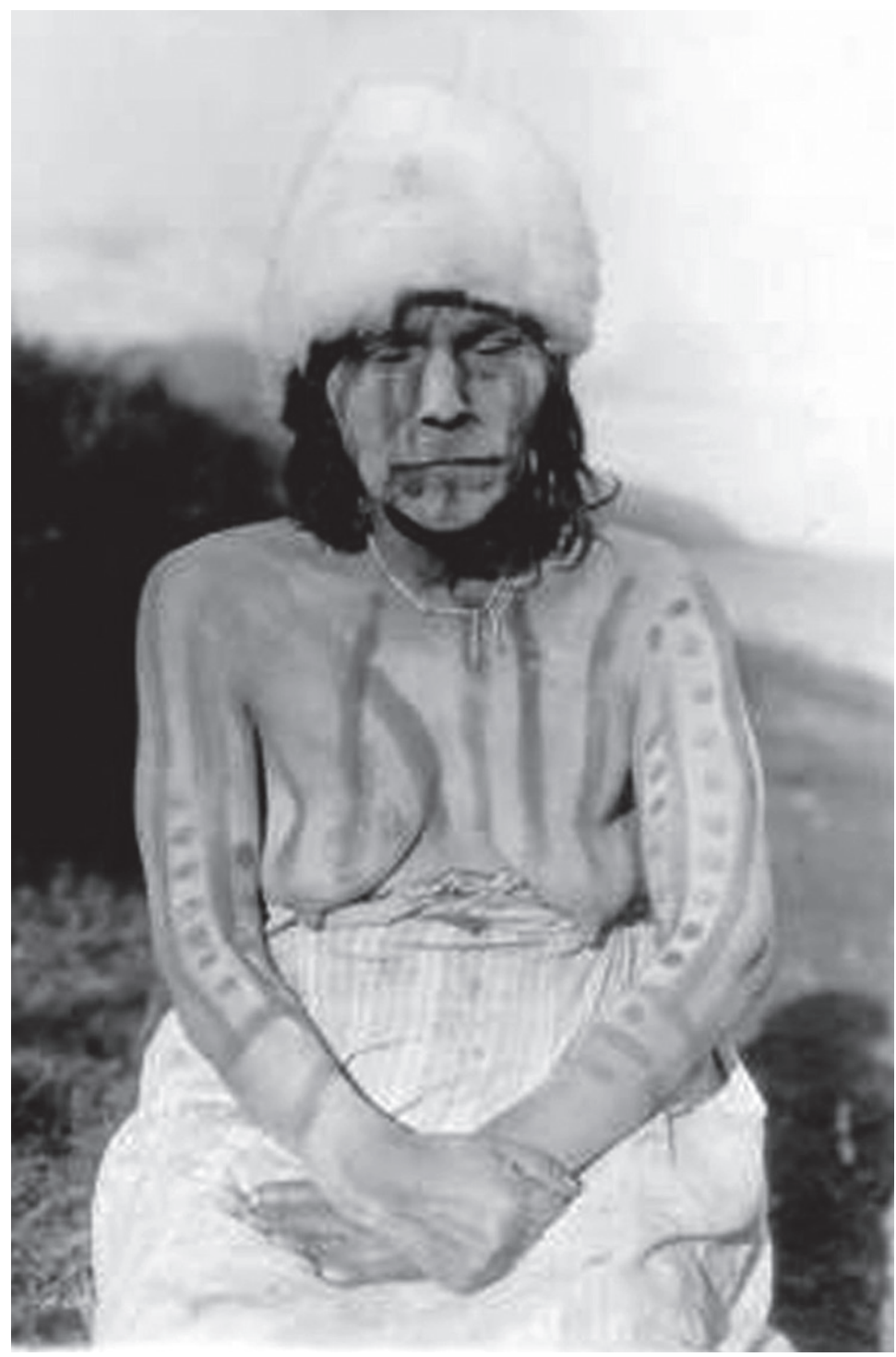

Fotografía de Wilhelm Koppers, 1922. 


\section{Figura 3}

Mujer yámana/yagán vistiendo un collar de caracoles

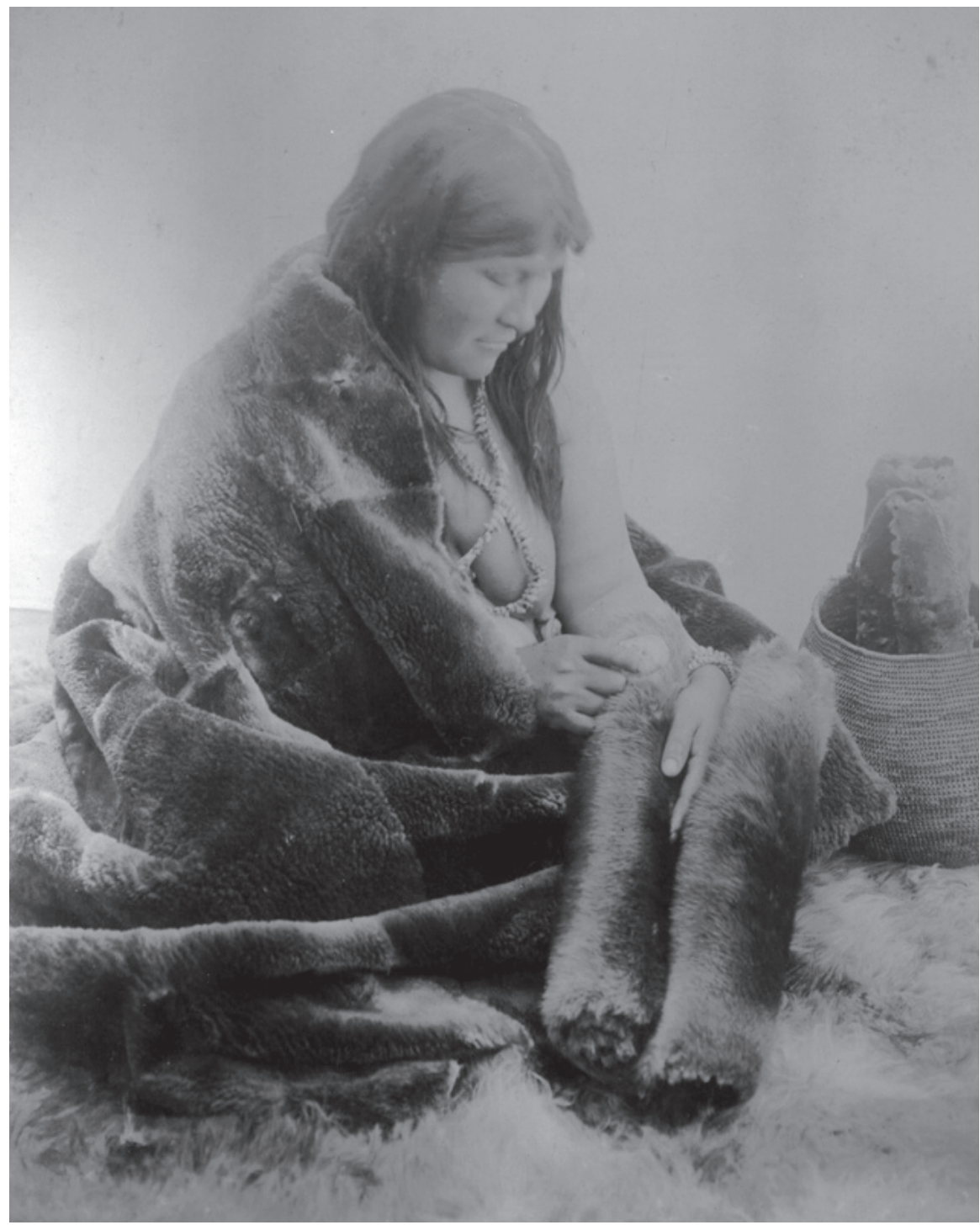

Fotografía de Ángeles Sánchez de Caballero, 1910-1920. 
Figura 4

Jóvenes yámana/yagán vistiendo collares de cuentas foráneas

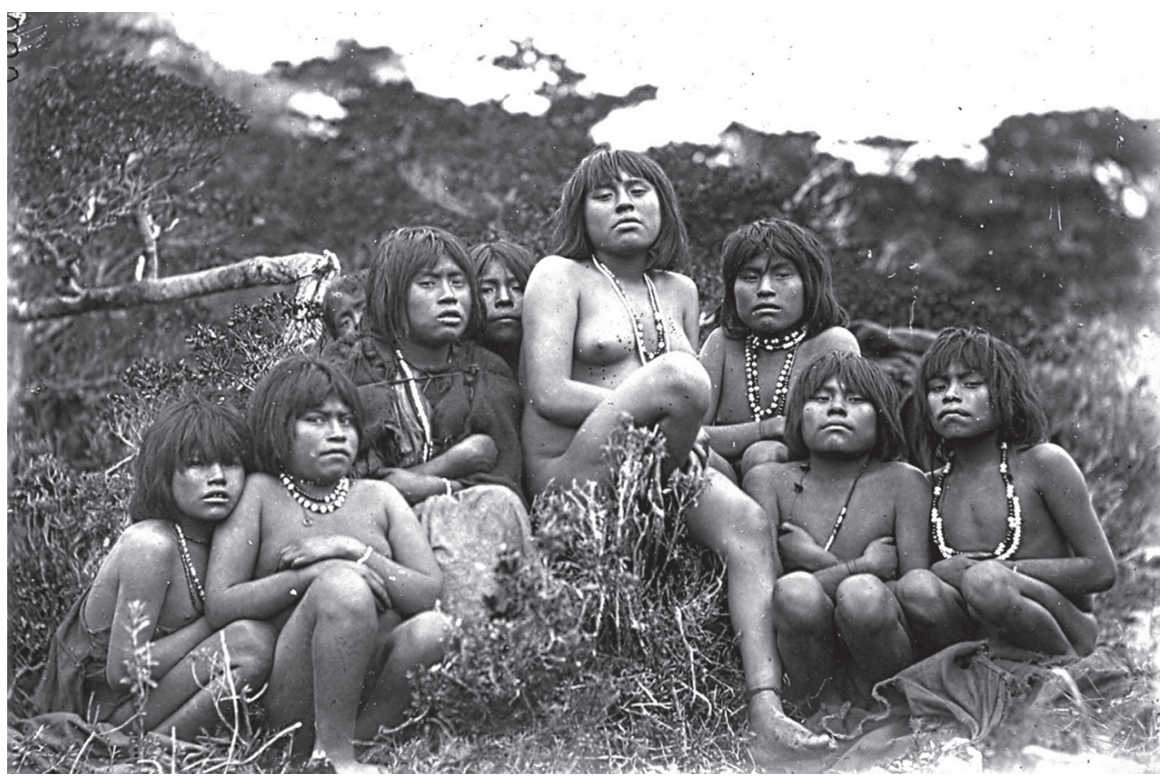

Fotografía de Jean Louis Doze y Edmond Payen, Misión Científica al Cabo de Hornos, 1882-1883.

Respecto del género, encontramos que todos los tipos de collares -salvo los de cuero- eran más usados por mujeres (66\% de 124 collares), siendo al parecer de uso exclusivamente femenino los de hueso, los de caracol y los de cuentas de metal (registrados todos en bajas frecuencias). Varios tipos de collares eran también usados por varones (34\% de 124 collares), siendo exclusivamente masculinos los de cuero. Es decir, las mujeres usaban 6 tipos de collares, de los cuales 3 habrían sido exclusivamente femeninos, mientras que los varones usaban 4 tipos de collares, de los cuales 1 habría sido exclusivamente masculino. Este predominio en cantidad y variedad de collares usados por las mujeres se condice con las observaciones de algunos viajeros y científicos, que habrían señalado la predilección femenina por este tipo de adornos (Fitz Roy, 1839; Hyades y Deniker, 2007 [1887]).

Interesantemente, encontramos que los collares autóctonos aparecen usados en la misma proporción por los varones (50\% de 8 collares autóctonos) 
que por las mujeres (50\%). Estos collares muestran una gran diferencia de género, ya que el único collar de hueso y los dos collares de caracoles eran usados solo por mujeres, mientras los cuatro collares de cuero lo eran solo por varones. Cabe mencionar que los collares de cuero usados por los varones podrían en realidad ser hondas usadas para cazar aves, que solían ser llevadas en el cuello (Orquera y Piana, 2015). De hecho, algunas fotografías retratan varones Yámana/Yagán portando collares de cuero apretados al cuello y hondas - con una tira triangular de cuero y dos correas que llegaban a la altura del ombligo-. Los collares foráneos siguen un patrón diferente, ya que la mayoría eran usados por mujeres (68\% de 117 collares foráneos), y pocos lo eran por varones (32\%). Así, las mujeres usaban más collares de cuentas blancas $(68 \%$ de 25 ), de cuentas oscuras ( $55 \%$ de 36 ), de cuentas blancas y oscuras $(75 \%$ de 55), y también el único collar de cuentas de metal.

Encontramos una posible regulación de género respecto del uso de los collares entre los Yámana/Yagán. Los collares autóctonos parecen obedecer a una regulación más estricta de género: las mujeres habrían usado collares de hueso y caracoles y los varones de cuero. Contrariamente, los collares foráneos fueron usados indistintamente tanto por mujeres como por varones, aunque en mayor proporción por las primeras. Este patrón de comportamiento observado en las fotografías etnográficas se condice con el observado por numerosos viajeros que entraron en contacto con los Yámana/Yagán: que los collares eran usados por ambos géneros, pero preferidos por las mujeres (Fitz Roy, 1839; Hyades y Deniker, 2007 [1891]; Gusinde, 1986 [1937]).

Los brazaletes fueron observados y mencionados por algunos de los viajeros que mantuvieron contacto con los Yámana/Yagán (Fitz Roy, 1839; Martial, 2007 [1888]; Hyades y Deniker, 2007 [1891]; Gusinde, 1986 [1937]) y también pueden ser caracterizados y clasificados sobre la base de su morfología y materia prima como autóctonos o foráneos. Los brazaletes autóctonos tenían unos $2 \mathrm{~cm}$ de ancho y eran confeccionados con "aros de cuero de lobo marino" (Martial, 2007 [1888], p. 31) o de guanaco, sujetados mediante una perforación o mediante nudos hechos con lazos de tendón (ver enumeración de citas en Orquera y Piana, 2015). Los brazaletes foráneos estaban compuestos por los mismos elementos occidentales que los collares: cuentas de vidrio y/o cerámica (Orquera y Piana, 2015) (Figura 5). En las fotografías aquí analizadas predominan levemente los brazaletes foráneos (55\% de 20 brazaletes) por sobre los autóctonos (45\%) (Tabla 2). 


\section{Figura 5}

Familia yámana/yagán. Algunos visten brazaletes de cuero, otros brazaletes de cuentas, además de collares y tobilleras

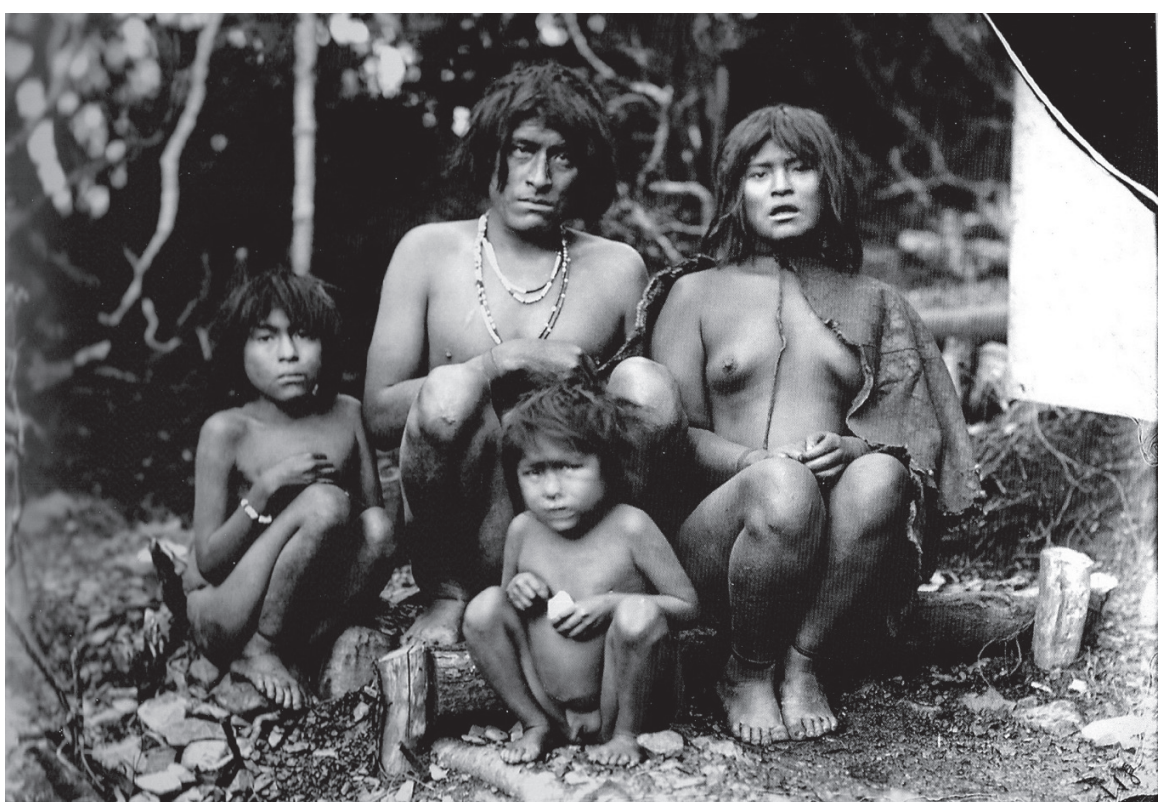

Fotografía de Jean Louis Doze y Edmond Payen, Misión Científica al Cabo de Hornos, 1882-1883.

Tabla 2

Tipos de brazalete por género

\begin{tabular}{|l|c|c|c|c|c|}
\hline \multirow{2}{*}{$\begin{array}{c}\text { Tipo de } \\
\text { brazalete/ } \\
\text { Género }\end{array}$} & Autóctonos & \multicolumn{3}{c|}{ Foráneos } & \multirow{2}{*}{ Total } \\
\cline { 2 - 5 } & cuero & $\begin{array}{c}\text { cuentas } \\
\text { blancas }\end{array}$ & $\begin{array}{c}\text { cuentas } \\
\text { oscuras }\end{array}$ & $\begin{array}{c}\text { cuentas blancas } \\
\text { y oscuras }\end{array}$ & \\
\hline Mujeres & 6 & 3 & 1 & 4 & 14 \\
\hline Varones & 3 & 3 & - & - & 6 \\
\hline Total & 9 & 6 & 1 & 4 & 20 \\
\hline
\end{tabular}

Elaboración: Autoras 
Al igual que en el caso de los collares, eran las mujeres quienes más usaban brazaletes ( $70 \%$ de 20 brazaletes), aunque también se los ve en algunos varones (30\%). De los cuatro tipos de brazalete identificados en las fotos, las mujeres usaban los cuatro y los hombres solo dos, mostrando que las mujeres vestían mayor cantidad y variedad de brazaletes. Este predominio se registra tanto en los brazaletes autóctonos (66\% de 9) como en los foráneos (72\% de 11). Ahora bien, los brazaletes foráneos presentan una situación más compleja: los brazaletes de cuentas blancas eran usados por mujeres y varones en la misma proporción ( $50 \%$ cada género), mientras que los brazaletes de cuentas oscuras y los que mezclaban cuentas blancas y oscuras eran usados solamente por mujeres.

Así, las fotografías documentan una interesante regulación de género: tanto los brazaletes autóctonos de tiento como los brazaletes foráneos de cuentas eran más usados por las mujeres que por los varones. Este predominio del uso femenino de brazaletes puede vincularse con las observaciones realizadas por algunos viajeros respecto de que eran las mujeres adultas y las niñas las que usaban los brazaletes (Hyades y Deniker, 2007 [1891]; Gusinde, 1986 [1937]).

Las tobilleras fueron observadas también por muchos de los viajeros que entraron en contacto con los Yámana/Yagán (Fitz Roy, 1839; Martial, 2007 [1888]; Hyades y Deniker, 2007 [1891]; Gusinde, 1986 [1937]). Las tobilleras autóctonas tenían unos $2 \mathrm{~cm}$ de ancho y podían estar confeccionadas en cuero de lobo marino o de guanaco, y no hay evidencia del uso de tobilleras foráneas (Orquera y Piana, 2015). A diferencia de los collares y los brazaletes, las tobilleras fotografiadas presentan muy baja variabilidad, ya que solo aparecen las autóctonas de cuero (Figura 6).

Estas tobilleras fueron usadas casi exclusivamente por mujeres (96\%) (Tabla 3); de hecho, un único varón Yámana/Yagán fue fotografiado usando una tobillera de cuero. De esta manera, las tobilleras presentan una regulación de género muy marcada, ya que parecen haber sido usadas casi exclusivamente por mujeres ${ }^{10}$.

10 Las tobilleras, aunque usadas casi exclusivamente por mujeres, no parecen estar asociadas a ningún rito de pasaje exclusivamente femenino, como la primera menstruación. Esta afirmación se basa en que: a) las tobilleras eran usadas indistintamente por adultas, jóvenes y niñas -aunque las últimas no habrían pasado por ese rito de pasaje-; b) ninguno de los viajeros y etnógrafos que registró datos sobre los Yámana/Yagán mencionó la asociación de las tobilleras con ese rito de pasaje y c) la única ornamentación asociada a ese ritual de pasaje femenino parece haber sido la pintura corporal (Fiore, 2002). 


\section{Figura 6}

\section{Yámanas/Yaganes vistiendo collares de cuentas}

\section{y la mujer vistiendo dos tobilleras de cuero}

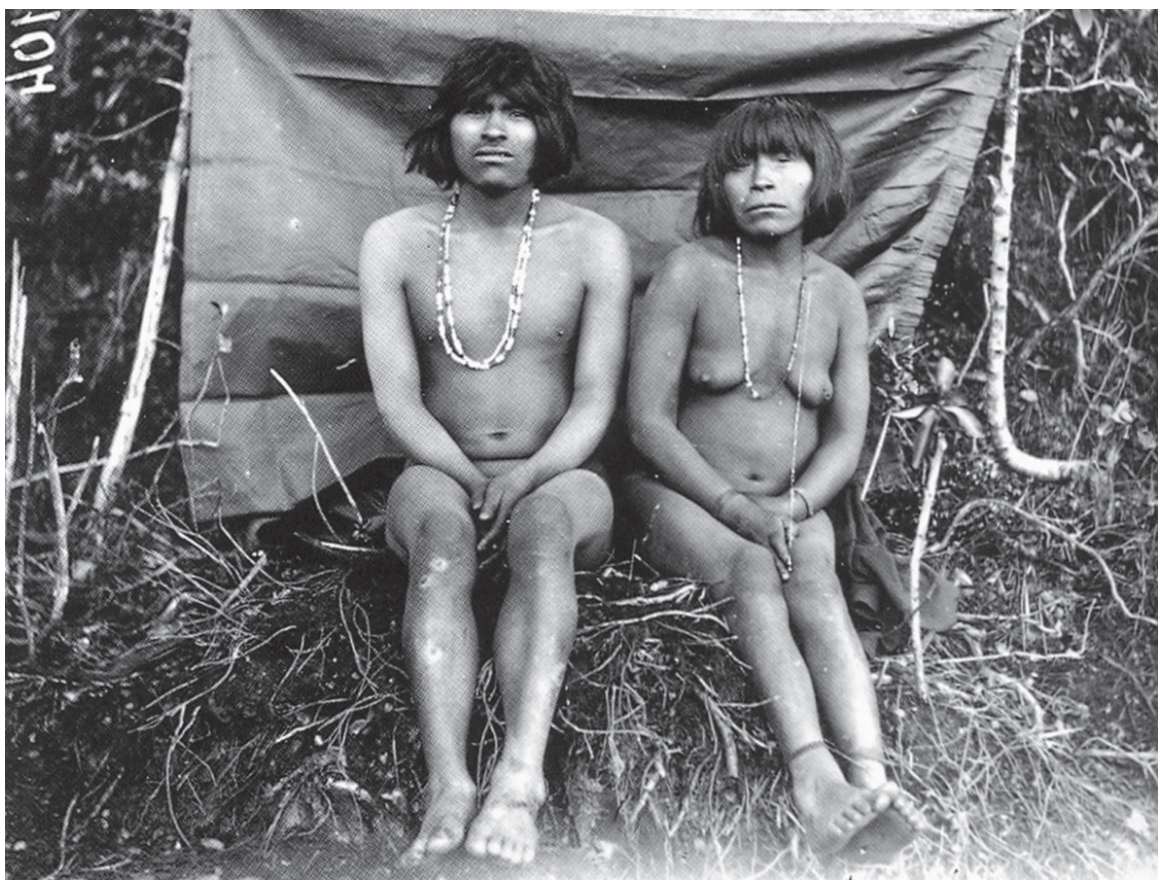

Fotografía de Jean Louis Doze y Edmond Payen, Misión Científica al Cabo de Hornos, 1882-1883.

Tabla 3

Tipo de tobilleras por género

\begin{tabular}{|l|c|}
\hline \multirow{2}{*}{ Tipo de tobilleras / Género } & Autóctonas \\
\cline { 2 - 2 } & cuero \\
\hline Mujeres & 26 \\
\hline Varones & 1 \\
\hline Total & 27 \\
\hline
\end{tabular}

Elaboración: Autoras 


\section{Discusión y reflexiones finales: una arqueología del registro visual fueguino}

A la hora de discutir estos resultados consideramos crucial tener en cuenta la demografía fotográfica que planteamos al comienzo del análisis, ya que muestra que en el corpus de fotografías etnográficas de Yámanas/ Yaganes existió una representación equilibrada de varones y mujeres, con un leve predominio de varones (52\%). De esta manera, el predominio de un tipo de adorno, femenino o masculino, no puede ser adjudicado a la mayor representación de un género, sino al predominio del uso de esos adornos. Esto por supuesto no implica que dicho registro sea una muestra objetiva de la realidad pasada (Barthes, 2004), pero permite, mediante una mirada arqueológica del registro fotográfico, "excavar" pautas y tendencias de uso de la cultura material ornamental, como parte de las formas de construcción y regulación de los géneros dentro de la sociedad Yámana/Yagan.

$\mathrm{Al}$ analizar los collares, brazaletes y tobilleras de acuerdo al género de quien los portaba, encontramos que la amplia mayoría de estos adornos corporales eran usados por mujeres ( $71 \%$ de 171 adornos). De estos tres tipos de adornos, los collares eran los más compartidos por mujeres (66\%) y varones (34\% de 124 collares); mientras los brazaletes eran usados en mayor proporción por mujeres (70\%) que por varones (30\% de 20 brazaletes); y las tobilleras lo eran casi exclusivamente por mujeres (96\% de 27 tobilleras) (Tabla 4).

\section{Tabla 4}

Tipo de adornos corporales por género

\begin{tabular}{|l|c|c|c|c|}
\hline \multicolumn{1}{|c|}{ Adornos/ Género } & Collares & Brazaletes & Tobilleras & Total \\
\hline Mujeres & 82 & 14 & 26 & 122 \\
\hline Varones & 42 & 6 & 1 & 49 \\
\hline Total & 124 & 20 & 27 & 171 \\
\hline
\end{tabular}

Elaboración: Autoras

Entendemos que el género implica una construcción social e histórica, fruto del efecto de la asignación de roles culturales a cada individuo según su corporalidad (incluyendo y excediendo a su sexo) y de la forma en que éste los asume, reproduce y/o desafía, mediante una creación y/o repe- 
tición ritualizada de gestos corporales y actos de habla (Conkey y Spector, 1984; Claassen, 1992; Butler, 2004). De esta manera, el género es siempre performativo, en tanto exige una actuación reiterada y estilizada de gestos, movimientos y estilos corporales socialmente determinados como parte de distintos géneros -que en el caso que nos ocupa hemos definido operativa y dicotómicamente como femenino o masculino, aunque reconocemos la existencia de variaciones internas- (Fiore, 2007). Esos actos, gestos y movimientos corporales son performativos, ya que refieren a una identidad de género visible mediante prácticas concretas -el vestir, el ornamentarse, el hablar-, inteligibles dentro de un campo cultural (Sørensen, 2000; Butler, 2004). Así, las prácticas asociadas a cada género son autopercibidas y percibidas por los otros como parte de ese género.

A partir de esta concepción de género, consideramos a los adornos corporales como parte de esas performances de género, en tanto el uso de adornos llevan al desarrollo de estilos corporales que habilitan tanto la autopercepción como la percepción por otros. Los adornos corporales son así experimentados en su uso corporal (se atan, se cuelgan, se enroscan e incluso perforan partes del cuerpo), pero también son exhibidos para un otro, que los decodifica como pertenecientes (o no) a un género, según los hábitos y regulaciones de género de su sociedad. Así, entendemos que en el caso Yámana/Yagán, el uso preferentemente femenino de collares, brazaletes y tobilleras podría referir a una "construcción visual diferencial del género femenino yámana" (Fiore y Varela, 2009, p. 219). Los collares eran los adornos más frecuentemente usados en la sociedad, y los que más se compartían entre mujeres y varones (aunque predominaban entre las primeras). Sin embargo, algunos tipos de collares parecen haber sido de uso exclusivo de cada género: los collares de hueso y de caracoles aparecen usados solo por mujeres y los collares de cuero solo por varones. De esta manera, es posible considerar que los collares autóctonos señalarían diacríticamente a su portador como perteneciente al género femenino o masculino; mientras los alóctonos habrían sido de uso indistinto respecto del género. En los Yámana/Yagán los brazaletes y las tobilleras aparecen visualmente más asociados al género femenino. En tal sentido, las inferencias efectuadas a partir de esta arqueología visual del registro fotográfico de este pueblo originario fueguino sugieren que mientras los collares foráneos implicaban regulaciones de género un poco más laxas, los collares autóctonos y las tobilleras implica- 
ban regulaciones de género bastante más estrictas, siendo los brazaletes un caso comparativamente intermedio.

Estas diferencias podrían surgir del hecho de que los collares foráneos habrían constituido una "novedad" atractiva para ambos géneros, que no habría estado impregnada de valores socioculturales que afectaran la regulación de su uso respecto del género del portador. Contrariamente, los ornamentos autóctonos habrían estado impregnados de valores socioculturales tradicionales más difíciles de cambiar, pese a que se registran algunas variaciones en su uso, tal como hemos documentado en las respectivas tablas de datos.

Es posible pensar que la presencia del fotógrafo podría haber influido en la construcción del registro fotográfico de estos ornamentos, especialmente porque las mujeres eran las más fotografiadas usando estos adornos. Los fotógrafos podrían haber favorecido tomas en las cuales las mujeres portaran collares, brazaletes y tobilleras, siguiendo sus propias normas occidentales, en las cuales se asocia lo femenino con la ornamentación y la "coquetería". La existencia de tomas en las cuales las mujeres aparecen como “cuerpos dóciles" (Masotta, 2003) y modelos eróticos (Carreño, 2002) es consistente con esta posibilidad. Sin embargo, también cabe señalar que, aunque más mujeres fotografiadas usaran ornamentos, no se ha registrado una homogeneidad de géneros en los tipos de ornamentos usados, ni tampoco patrones enteramente azarosos, opciones de lo que podria haber ocurrido si las fotografías hubieran sido producidas de acuerdo al imaginario de los fotógrafos. Es aquí donde consideramos que entra a operar la agencia de los propios sujetos fotografiados (sensu Giddens, 1995; Fiore, 2007; Fiore y Varela, 2009), ya que las tendencias halladas en el uso de tipos de ornamentos habrían sido generadas por las propias prácticas y hábitos de las personas fotografiadas, interpretables como señales de las performances de género de los Yámana/Yagán.

De esta manera, consideramos que la antropología visual puede enriquecerse mediante una mirada arqueológica, al recuperar el valor etnográfico de las fotografías y tratarlas como artefactos que aportan información sobre pautas de comportamiento de estas poblaciones indígenas en el pasado reciente. El análisis sistemático y profundo de estos artefactos visuales permite aportar nuevos datos acerca de la forma en que las sociedades indígenas construían los roles y regulaciones de género, mostrando que existieron múltiples formas de pensar y actuar lo femenino y lo masculino. 


\section{Agradecimientos}

Los resultados aquí presentados forman parte de las investigaciones llevadas a cabo por las autoras en el marco del CONICET y la AIA. Agradecemos especialmente a los museos y archivos y al ARC-FOT-AIA, donde hemos podido recopilar la muestra fotográfica aquí analizada. Expresamos también nuestra gratitud a Luis Orquera, director de la AIA y experto en arqueología de la región habitada por los Yámana/Yagán, por su constante apoyo a nuestras investigaciones y sus atinados comentarios al manuscrito.

\section{Bibliografía}

Alvarado, M. (2007). Vestidura, investidura y despojo del nativo fueguino. En M. Alvarado, C. Odone, F. Maturana \& D. Fiore (Eds.), Fueguinos. Fotografías siglos XIX y XX. Imágenes e imaginarios del fin del mundo (pp. 61-73). Santiago de Chile: Pehuén.

Alvarado, M. y P. Mason (2005). Fueguia Fashion. Revista Chilena de Antropología Visual 6, 2-18.

Báez, C., y Mason, P. (2006). Zoológicos humanos. Fotografías de fueguinos y mapuche en el Jardin d'Acclimatation de París, siglo XIX. Santiago de Chile: Pehuén.

Báez, C. (2005). Uso y abuso la construcción del indígena fueguino en los textos escolares a través de la imagen fotográfica. Revista Chilena de Antropología Visual 6, 19-33.

Barthes, R. (2004). La cámara lúcida. Buenos Aires: Paidós.

Batchen, G. (2004). Arder en deseos. La concepción de la fotografía, Barcelona: Editorial Gili.

Bazin, A. (1960). The Ontology of the Photographic Image. Film Quarterly, 13(4), 4-9.

Benjamin, W. (2015). Estética de la imagen. Buenos Aires: La Marca editora.

Bourdieu, P. (1979). La fotografía: un arte intermedio. México: Nueva Imagen.

Bridges, L. (2005 [1948]). El último confin de la tierra. Buenos Aires: Sudamericana.

Butler, J. (2004). Regulaciones de género. Londres: Routledge, Taylor \& Francis Group.

Butto, A. (2016). MS Huellas visuales, huellas materiales. Sitios y artefactos de indígenas patagónicos y fueguinos registrados en las fotografías tomadas durante la conformación y expansión del estado-nación argentino 
(1860-1940) y sus implicancias para el registro arqueológico. Tesis Doctoral. Universidad de Buenos Aires: Facultad de Filosofía y Letras.

Carreño, G. (2002). Fotografías de cuerpos indígenas y la mirada erótica: reflexiones preliminares sobre algunos casos del confín austral. Revista Chilena de Antropología Visual 2, 133-153.

Claassen, C (1992). Exploring Gender through Archaeology: Selected Papers from the 1991 Boone Conference. Madison: Monographs in World Archaeology 11 , Prehistory Press.

Conkey, M y Gero, J (1991). Engendering Archaeology: Women and Prehistory. Oxford: Blackwell.

Conkey, M and Spector, J (1984). Archaeology and the study of gender. En M. Schiffer (Ed.), Advances in Archaeological Method and Theory 7 (pp. 1-38). New York: Academic Press.

Collier, J. (1995). Photography and visual anthropology. Hockings, 235-254.

Costa, J. (1991). La fotografía, entre sumisión y subversión. México: Editorial Trillas. Dubois, P. (2008 [1990]). El acto fotográfico y otros ensayos. Buenos Aires: La Marca Editora.

Edwards, E. (1992). Anthropology and Photography 1860-1920. Londres: Yale University Press.

Fiore, D. (2002). Body Painting in Tierra del Fuego. The power of images in the uttermost part of the world. Tesis Doctoral. London: University of London.

Fiore, D. (2005). Fotografía y pintura corporal en Tierra del Fuego: un encuentro de subjetividades. Revista Chilena de Antropología Visual 6, 55-73.

Fiore, D. (2007). Painted genders. The construction of gender through the display of body painting by the Selk'nam and the Yámana from Tierra del Fuego (Southern South America). En Women and Archaeology (pp. 373-404). California: Left Coast Press.

Fiore, D. y M. L. Varela (2009). Memorias de papel. Una arqueología visual de las fotografías de pueblos originarios fueguinos. Buenos Aires: Editorial Dunken.

Fitz-Roy, R. (1839). Narrative of the surveying voyage of his majesty's ships Adventure and Beagle between the years 1826 and 1836. Londres: Henry Colburn.

Flusser, W. (1990). Hacia una filosofía de la fotografía. México: Editorial Trillas.

Freund, G. 2015 [1974]. La fotografía como documento social. Barcelona: Editorial Gustavo Gili.

Giddens, A. (1995). La constitución de la sociedad: Bases para la teoría de la estructuración. Buenos Aires: Amorrortu. 
Grimshaw, A. (2001). The Etnographer's Eye. Ways of seeing in anthropology. Londres: Cambridge University Press.

Gusinde, M. (1986 [1937]). Los indios de Tierra del Fuego. Los Yamanas. I-II-III. Buenos Aires: Consejo Nacional de Investigaciones Científicas.

Hyades, P. y J. Deniker (2007 [1891]). Etnografía de los indios yaghan en la Misión científica del Cabo de Hornos 1882-1883. Punta Arenas: Ediciones Universidad de Magallanes.

Kossoy, B. (2001). Fotografía e historia. Buenos Aires: La Marca Editora.

Martial, L. F. (2007 [1888]). Etnografía de los indios yaghan en la Misión científica del Cabo de Hornos 1882-1883. Punta Arenas: Ediciones Universidad de Magallanes.

Masotta, C. (2003). Cuerpos dóciles y miradas encontradas. Miniaturización de los cuerpos e indicios de la resistencia en postales de indios argentinas (1900-1940). Revista Chilena de Antropología Visual 3, 1-16.

Naranjo, J. (2006). Fotografía, antropología y colonialismo. Barcelona: Editorial Gustavo Gili.

Orquera, L. y E. Piana (1999). Arqueología de la Región del Canal Beagle (Tierra del Fuego, República Argentina). Buenos Aires: Sociedad Argentina de Antropología.

Orquera, L. y E. Piana (2015 [1999]). La vida social y material de los Yámana. Ushuaia: Monte Olivia.

Peirce, C. (1995). Philosophical writings of Peirce. New York: Dover Publications. Penhos, M. (2005). Frente y perfil. Fotografía y prácticas antropológicas y criminológicas en Argentina a fines del siglo XIX y principios del XX. En Arte y antropología en la Argentina. Buenos Aires: Fundación Telefónica / Fundación Espigas / FIAAR.

Poole, D. (2000). Visión, raza y modernidad. Una introducción al mundo andino de imágenes. Lima: Casa de Estudios del Socialismo.

Ruby, J. (1996). Visual Anthopology, En D. Levinson y M. Embers (Eds.), Encyclopedia of Cultural Anthropology 4 (pp. 1341-1351). New York: Henry Holt and Company.

Saletta, M. J. (2011). Fotografías de indígenas en manuales escolares argentinos: representaciones visuales y connotaciones textuales. Intersecciones en Antropología, 13, 181-195.

Scherer, J. C. (1995). Ethnographic photography en anthropological research. Hockings, 201-216. 
Sørensen, ML (2000). Gender Archaeology. Cambridge: Polity Press.

Tagg, J. (2005). El peso de la representación. Barcelona: Editorial Gustavo Gili.

Fecha de recepción: 22/05/2017; fecha de aceptación: 28/07/2017;

fecha de publicación: 01/09/2017 


\title{
El etnógrafo y la cámara en la producción audiovisual de productores informales ${ }^{1}$
}

\section{The Ethnographer and the camera in the audiovisual production of informal producers}

\author{
Eduardo Fabio Henríquez Mendoza ${ }^{2}$ \\ aztecaurbana@gmail.com
}

Filmar lo que sucede se vuelve más complejo que filmar lo que hacemos suceder Carmen Guarini, Meykinof (2005)

\begin{abstract}
Resumen
Este trabajo estudia el uso de la cámara como dispositivo de diálogo, interacción y reflexión entre etnógrafo audiovisual y los productores informales de Santo Domingo de los Colorados Ecuador. Además, expone mediante una serie de interrogantes cómo el etnógrafo audiovisual piensa y aborda los procesos metodológicos y teóricos en el trabajo de campo, obteniendo como resultados la necesidad de potenciar la utilidad del texto audiovisual como lenguaje que evidencia el rigor científico que permite rescatar múltiples agencias y reflexionar sobre la teoría de la Antropología Audiovisual, considerando otros caminos en la producción de conocimientos.
\end{abstract}

\section{Palabras claves}

Antropología, metodología, etnografía, audiovisual, representación.

Forma sugerida de citar: Henríquez Mendoza, Eduardo Fabio (2017). El etnógrafo y la cámara en la producción audiovisual de productores informales. Universitas, XV(27), pp. 93-115.

1 El presente artículo fundamenta uno de los resultados obtenidos durante la etnografía audiovisual de mi proyecto de investigación doctoral: Análisis de las representaciones en las narrativas audiovisuales de productores informales en Ecuador a partir de una etnografía audiovisual de sus estilos, escenografías y distribuciones comerciales, bajo la tutoría de: Dr. Jorge Grau Rebollo de la Universidad Autónoma de Barcelona y Dr. Juan Ignacio Robles Picón de la Universidad Autónoma de Madrid.

2 Universidad Autónoma de Barcelona. Candidato a Doctor en Antropología Social y Cultural. Contacto principal para la correspondencia editorial. Orcid: 0000-0001-6102-9809 


\begin{abstract}
This work studies the use of the camera as a device for dialogue, interaction and reflection between the audiovisual ethnographer and the informal producers of Santo Domingo de los Colorados Ecuador. In addition, it explains through a series of questions how the audiovisual ethnographer thinks and approaches the methodological and theoretical processes in the field work. As a result I obtained the necessity to strenghten the usefulness of the audiovisual text as a language that, on the one hand, evidence scientific rigor and, on the other hand, allows to rescue multiples agencies and think about the theory of Audiovisual Anthropology, considering other paths in the creation of knowledge.
\end{abstract}

Keywords

Anthopology, methodology, ethnography, audiovisual, performance.

\title{
Preproducción
}

\section{Introducción}

La Antropología Audiovisual centra su interés en observar, describir, estudiar y registrar las diversas manifestaciones visuales y sonoras de la naturaleza simbólica humana. Estas manifestaciones son percibidas y captadas en diferentes contextos donde las imágenes y sonidos son recreados en representaciones sociales y expresiones culturales (Ardèvol, 1994; Grau Rebollo, 2002; Guarini \& De Angelis, 2014; Hockings, 2003; Lisón Arcal, 1999; Mead, 1995; Piault, 2002; Robles Picon, 2012; Rouch, 1995; Ruby, 2007).

No ha sido fácil posicionar a la Antropología Audiovisual y sus métodos etnográficos audiovisuales al nivel de rigor científico. Pero es paradójico pensar que, en nuestra época, donde lo audiovisual es imperante los estudios realizados por esta rama disciplinar aún resulten imprecisos. Ha sido difícil la tarea, pero en esa lucha contra la incertidumbre, se ha comprobado que en el camino del quehacer epistemológico existe la constante representación de la imagen dibujada, narrada y retratada en los cuadernos de campo (Grau Rebollo, 2008). El registro muestra ese anhelo por describir y proyec- 
tar "lo real" y evidenciar "el estar allî" de situaciones, olores, colores, temperaturas y sentires captados por el cuerpo del etnógrafo. Más aun cuando el cuerpo que observa, escucha e interactúa con los sujetos y objetos simbólicos durante el trabajo de campo no se presenta invisible, sino integrado ante el contexto y sus protagonistas.

No obstante, ¿puede una cámara sesgar la mirada científica del etnógrafo en el trabajo de campo? Esta pregunta ha retumbado, rebotado y animado diversos debates sobre la representación de la alteridad en los escenarios de las ciencias sociales. No se puede negar que la presencia de la cámara en el trabajo etnográfico todavía resulta extraña para los agentes culturales estudiados. Pero esta extrañeza no se presenta de forma negativa, sino como estímulo de múltiples situaciones en la participación colaborativa entre etnógrafo y agente cultural.

La cámara puede activar la memoria humana, por ejemplo los recuerdos en torno a los objetos, lugares, eventos y artefactos culturales. Estas memorias sirven tanto al etnógrafo como al agente cultural, debido a que recrean situaciones que ayudan a comprender determinados fenómenos sociales. Asimismo, este dispositivo ejerce como cuaderno de campo audiovisual y fotográfico, dado que, enriquece, facilita y proporciona mayores posibilidades de análisis y apropiación de lo estudiado (Ardèvol \& Pérez Tolón, 1995; Boudreault-Fournier, Caiuby Novaes, \& Gitirana Hijiki, 2017; González, 2011; Grau Rebollo, 2008; Guarini \& De Angelis, 2014).

Por consiguiente, los esfuerzos en posicionar académicamente la Antropología Audiovisual y sus métodos etnográficos, se evidencian en variadas investigaciones realizadas por diferentes instituciones de Latinoamérica como en la maestría en Antropología Visual de FLACSO, Ecuador, la Universidad Andina Simón Bolívar de Ecuador con el Coloquio internacional de cine documental, el Instituto Colombiano de Antropología e Historia, el área de Antropología Visual de la Facultad de Filosofía y Letras de la Universidad de Buenos Aires, la Revista Chilena de Antropología, la Maestría en Antropología Visual de la Pontificia Universidad Católica de Perú, las Jornadas de Antropología Visual en la Escuela Nacional de Antropología e Historia de México, el Laboratorio de Imagen y Sonido en Antropología de la Universidad de São Paulo, el Laboratorio de Antropología Visual de la Universidad Federal de Pernambuco, el Festival Internacional de Film Etnográfico de Recife de Brasil, Festival de Cine Etnográfico de Ecuador, entre otras plataformas e instituciones que realizan estudios audiovisuales (Andrade \& Zamorano, 2012; Mardones \& Riffo, 2011). 
Estas plataformas han permitido tener un amplio registro de acontecimientos, memorias, representaciones, imaginarios, rituales, cotidianidades y contextos que sirven para reconocer y diferenciar situaciones de la amplia colcha de retazos culturales, políticos y religiosos de Latinoamérica. Registros etnográficos que facilitan visualizar, analizar y evidenciar detalles que abren otras rutas para el conocimiento antropológico que en la observación directa, la participación y la descripción escrita del trabajo etnográfico no se podrían transmitir. Estos registros pueden ser reproducidos por la asequibilidad e instantaneidad del nuevo sistema mundo llamado internet y del bajo costo tecnológico. Asequibilidad que amplía y enriquece el análisis cultural y contextual que se presentan como metáforas consecuentes de las imágenes reflejadas infinitivamente en espejos paralelos (Ardevol \& Estalella, 2010; Caiuby Novaes, 1993; Cárdenas \& Duartes, 2011; Hine, 2004; Pink, 2003; Rose, 2007).

Hoy en día, diversas manifestaciones sociales son representadas en narrativas audiovisuales, como en el caso de estudio de esta investigación, que tiene como objetivo reflexionar en torno al uso de la cámara en el trabajo etnográfico audiovisual como dispositivo de diálogo, interacción y reflexión entre etnógrafo audiovisual y las perspectivas de la preproducción, producción y postproducción de los productores informales en los contextos del rodaje. En ella se encontró que el fácil acceso y bajo costo de las cámaras de video digital han permitido construir narrativas audiovisuales independientes de los fenómenos económicos del comercio formal. En estas narrativas se reproducen situaciones que demarcan estereotipos sociales, estados de ánimos, deseos, sueños, esperanzas, ideales, imaginarios que refuerzan la memoria de una familia, colectividad, sociedad, ciudad o país. Representaciones dinámicas de la creatividad social que hacen frente a las situaciones culturales y políticas que los rodean.

Existen en Latinoamérica diversas corrientes audiovisuales que tratan de emular desde sus percepciones locales los estilos del cine hollywoodense. En el caso particular de Ecuador encontramos estudios sobre estas corrientes como Ecuador Bajo Tierra: videografías en circulación paralela ${ }^{3}$ que contiene un catálogo detallado de cortometrajes y largometrajes realizados en 8 provincias representadas por 11 ciudades del país desde 1980 hasta el 2009 (Alvear \& León, 2009). Así mismo, Chonewood: etnografía, cine

3 Para este artículo utilizaremos el término narrativas audiovisuales indistintamente para hacer referencia a videografía o cine popular u otra categorización del cine de bajo presupuesto. 
popular y asesinato por encargo en Chone que es un estudio profundo sobre el entrecruzamiento entre los audiovisuales populares de bajo presupuesto producidas en la costa ecuatoriana y los relatos de sicariato representados en estas (Vaca, 2015).

Para esta investigación se realizó etnografía audiovisual de forma alternada a dos productoras de narrativas audiovisuales en formato DVD, de la ciudad de Santo Domingo de los Colorados, desde el 2013 hasta inicios del 2017. Las características de estas productoras delimitaban tópicos específicos de la muestra a seguir, tales como: a) productores informales sin estudios reglados en cinematografía ni artes escénicas, ni actuación, b) que sus oficios estén dentro de la informalidad o mano de obra no cualificada, c) las narrativas audiovisuales en formato DVD sean comercializadas en los circuitos del comercio informal y, d) que no hayan recibido ayudas económicas estatales. Durante el seguimiento de sus procesos de producción se encontraron diversos contextos representados desde sus percepciones de la realidad, donde retratan, muestran y crean una memoria social de una ciudad marginal, violenta, negada, olvidada para aquellos que la habitan desde otras realidades. Como resultado de esta etnografía audiovisual se obtuvieron dos documentales etnográficos que evidencian las percepciones y representaciones de universos sociales que coexisten paralelamente.

Durante la revisión bibliográfica, planificación y ejecución del trabajo de campo se planteó una serie de reflexiones y cuestionamientos que dieron paso a este artículo. La planificación se amoldó a los contextos, las condiciones cambiantes y espontáneas de la experiencia etnográfica entre el antropólogo, la cámara y los productores informales.

Este artículo está estructurado en las tres fases de la producción audiovisual. La preproducción que aborda la introducción partiendo con la reflexión al constante crecimiento de la Antropología Audiovisual en Latinoamérica y expone el objetivo de este documento, asimismo expone las cuestiones teóricas y metodológicas. La producción, se concibe desde una postura ética que esclarece el rol que desempeña el etnógrafo audiovisual en el trabajo de campo frente a los productores informales. La postproducción muestra las discusiones y la retroalimentación, alcanzando acuerdos que benefician tanto el trabajo antropológico como el trabajo de los productores informales. Finalmente, se presentan las consideraciones que exponen la necesidad de brindar mayor relevancia al documento etnográfico audiovisual. 


\section{ENTRE TEORÍAS Y METODOLOGÍAS}

El anclaje teórico de esta investigación parte de la mirada que ha tenido la etnografía audiovisual como creadora de conocimiento científico en el estudio de la representación cultural enlazado con el análisis de la representación en Antropología Audiovisual, entendiendo así que el conocimiento del quehacer antropológico se genera, en gran medida, gracias a las experiencias de las prácticas etnográficas.

El abordaje epistemológico permitió acceder a los aspectos de la cultura material, condición económica y trayectorias biográficas de los productores informales. La confluencia entre la teoría del conocimiento antropológico abordado y la práctica etnográfica audiovisual generó reflexiones que se enfocan en tres aspectos.

a. El conocimiento sobre su cultura material que parte de la relación empírica que estos objetos han aportado en su instrucción e interacción social. Ejemplo de ello son las herramientas utilizadas en la labor del campo que representan el trabajo, la economía y el nivel adquisitivo de un individuo en sociedad. Estas mismas herramientas se transforman en la utilería de sus producciones, que en la mayoría de los casos son asociadas como utensilios de seguridad, defensa o violencia en sus narrativas audiovisuales.

b. La condición económica representada por el hábitat se caracterizó por la marginalidad urbana. Los productores informales al proceder de familias campesinas migrantes, económicamente limitadas y al no poseer títulos profesionales, se ven obligados a la subsistencia laboral de la mano de obra no cualificada y al comercio informal, aunque aceptan las reglas e irregularidades del mundo que los rodea, ellos buscan superar obstáculos y anhelan vivir en condiciones dignas, realidad que no se diferencia de las aspiraciones sociales de aquellos que tienen los medios culturales y económicos. Sus aspiraciones se encuentran representadas constantemente como, felicidad, familia, ascenso social, calidad de vida, buen vivir entre otros deseos.

c. Las trayectorias biográficas se encuentran representadas en sus narrativas audiovisuales como imaginarios donde depositan tanto parte de su memoria como lo que esperan llegar a ser. Aspectos auto-representados en sus percepciones del hábitat y habitus, manifestándose como un "bricoleur" en cuanto a su actuación espontánea, las esce- 
nas improvisadas y el aprovechamiento de espacios y tiempos representados en sus relatos (Capdevielle, 2011; Mélice, 2009).

Para abordar el trabajo de campo se utiliza el modelo metodológico de la etnografía audiovisual desde las siguientes preguntas: ¿cómo diferenciar en el trabajo de campo el rol del etnógrafo y la cámara frente al camarógrafo de las producciones informales?, ¿cómo alcanzar la observación audiovisual rigurosa que demanda la disciplina antropológica?, ¿cómo se tejen las imágenes en el lenguaje escrito y el lenguaje audiovisual? Todos ellos responden a cuestionamientos que guían esta reflexión y que, además, se fueron despejados mediante la lectura de múltiples textos que acreditaron diversas repuestas desde sus experiencias y teorías (Ardèvol, 1994; Asch \& Asch, 1995; Cardenas \& Duartes, 2011; De Brigard, 1995; Grau Rebollo, 2005; MacDougall, 1995; Piault, 2002; Potts, 2015; Robles Picon, 2012).

Se optó por tres modalidades formales para representar el texto audiovisual: el cine observacional, el "documental participativo" y la implementación del dispositivo audiovisual como herramienta de interacción, provocación y reflexión. La primera permitió dar importancia a los "planossecuencia largos con profundidad de campo y la preservación de la unidad espacial y temporal de los eventos durante el rodaje y montaje" (Lacerda, 2015 , p. 1). La segunda, "documental participativo" o "modalidad interactiva" como la define Bill Nichols facilita la aproximación "más plenamente al sistema sensorial humano: mirando, oyendo y hablando a medida que percibía los acontecimientos y permitiendo que se ofreciera una respuesta" (1997, p. 79), características que nos llevan a la tercera modalidad y que también se evidencian en el cine de Jean Rouch y Edgar Morín denominado cinéma vérité en su filmografía Crónica de un verano (1961), según Rouch la interacción lleva a la utilización de la cámara como dispositivo que produce la "verdad del cine" (Canals i Vilageliu, 2011). Este acto se evidencia en dos aspectos: primero, la cámara como mediador entre productor informal y etnógrafo audiovisual (fotografía 1) ${ }^{4}$. Segundo, el investigador reflexiona sobre la auto-representación que realizan los agentes culturales en sus narraciones audiovisuales y en su propia representación documental. Esto genera un tipo de doble espejo entre la realidad captada y representada

4 Las fotografías en este artículo no se organizan en orden cronológico, solo en función de ejemplos concretos. 
audiovisualmente por el etnógrafo y la realidad representada por los productores informales (Boudreault-Fournier et al., 2017; Caiuby Novaes, 1993).

\section{Fotografía 1 \\ La cámara como dispositivo de interacción}

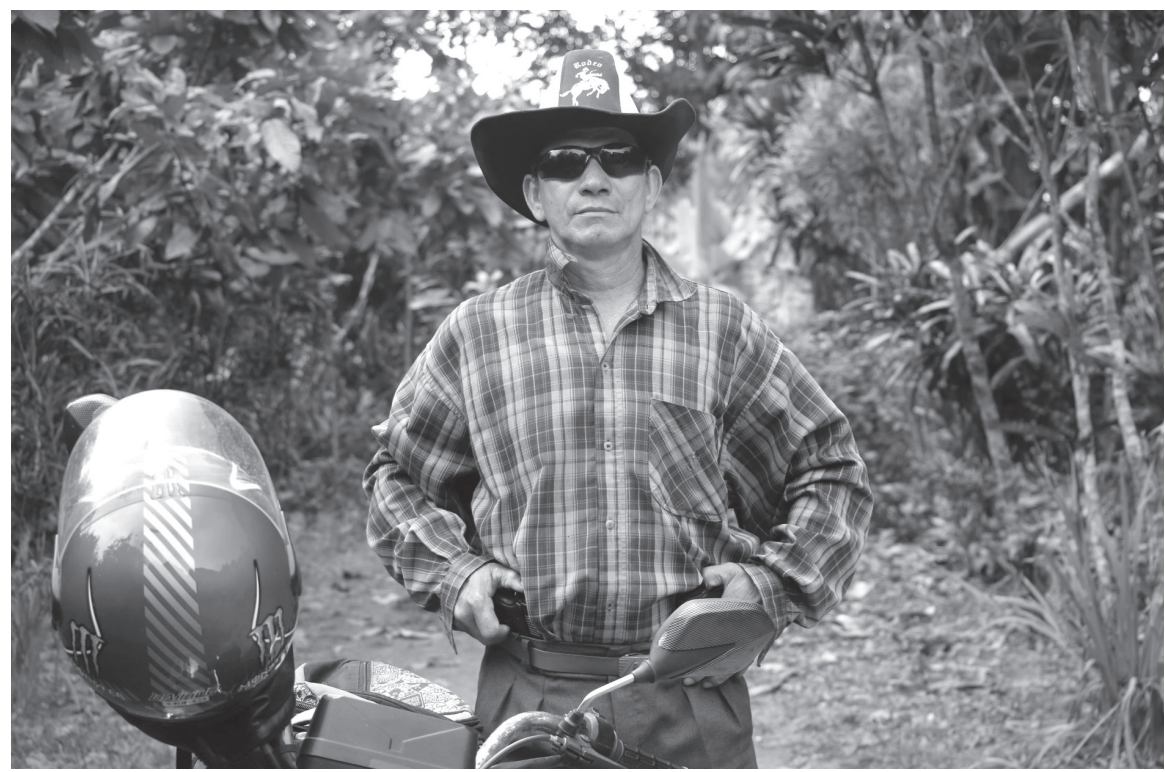

Exterior hacienda de amigos de los productores, primer día de rodaje. Uno de los actores me dice: "sácame una foto con mis armas, para enmarcarla y ponerla en la sala de mi casa" en la Manga del Cura (Manabí). Fuente: archivo fotográfico del autor (2016)

La teoría dicta que "los objetivos del cine observacional se dirigen hacia el análisis del comportamiento, mientras que el cine directo intenta reflejar la espontaneidad de la situación" (Ardèvol, 1998, p. 231). Se consideró por lo tanto que el tratamiento cinematográfico cuente con algunas características formales logradas por documentales como Meykinof (2005) de Carmen Guarini, en el que la mirada hacia la realización de un film de ficción se vuelve objeto de estudio antropológico. Guarini reflexiona y cuestiona constantemente lo capturado por su cámara. Su mirada etnográfica gira en torno a la interacción, relación y accionar que existe entre la "inmanencia de la imagen" audiovisual y el realismo de la "imagen-acción" (Deleuze, 
1984, p. 178). En el documental escuchamos su voz en off como banda sonora que une los bloques por medio del análisis y sus relatos. Igualmente, el enfoque de David MacDougall en Gandhi's Children (2008), donde los modos de representar las realidades, rituales de rivalidad, amistad, crueldad y generosidad van descubriendo la personalidad de los estudiantes. Y, por último, Los espigadores y la espigadora (2000) de Agnès Varda, quien muestra los métodos en su recolección cuando ella aparece en escena evidenciando su mirada. Esa mirada que convierte a la cámara en instrumento narrativo de acumulación y reciclaje. En este film se muestra cómo se desdibujan las fronteras entre autor y modos de representar el tema de espigar o recoger en la filmación y el tema en sí mismo. Estos tratamientos ayudaron a definir los modos de representación de una metodología que precisó, percibió, evidenció y activó los conceptos teóricos en el documento audiovisual.

La filmación se realizó de forma individual, utilizando la cámara en mano o en trípode y un micrófono externo, lo que fue un tanto limitado y laborioso. Las limitaciones técnicas y del recurso humano influyen a la hora del rodaje y la edición. Las dificultades, que se pueden convertir en oportunidades posteriormente, se presentan en los contextos del rodaje etnográfico audiovisual. En nuestro caso de estudio, se procuró no modificar los errores técnicos presentados al momento del rodaje de la narrativa audiovisual, ni del documental final. Esta interacción permitió capturar el registro audiovisual como exposición holística de la realidad observada y prescindir de otros recursos como cabezas parlantes o voz en off durante el montaje.

\section{Producción}

\section{Entre hallazgos y análisis}

Toda etnografía audiovisual parte del conocimiento empírico y teórico de su agente cultural. Desde el primer acercamiento al campo se debe ser honesto y dejar claro el rol del etnógrafo. En los contextos de rodajes de las realizaciones audiovisuales los artistas ocasionales confundían la presencia del etnógrafo con la cámara del camarógrafo de la película, esta situación resultaba ser incómoda para el camarógrafo de la producción por que tenía que repetir la toma, entonces ¿Cómo diferenciar en el trabajo de campo el rol del etnógrafo y la cámara frente al camarógrafo de las producciones in- 
formales? En principio repetir una y otra vez los arquetipos dispuestos en las respuestas establecidas, durante la posición ética del etnógrafo en el campo de trabajo.

\section{Fotografía 2 \\ Camarógrafo del rodaje, entre su rol y mi rol}

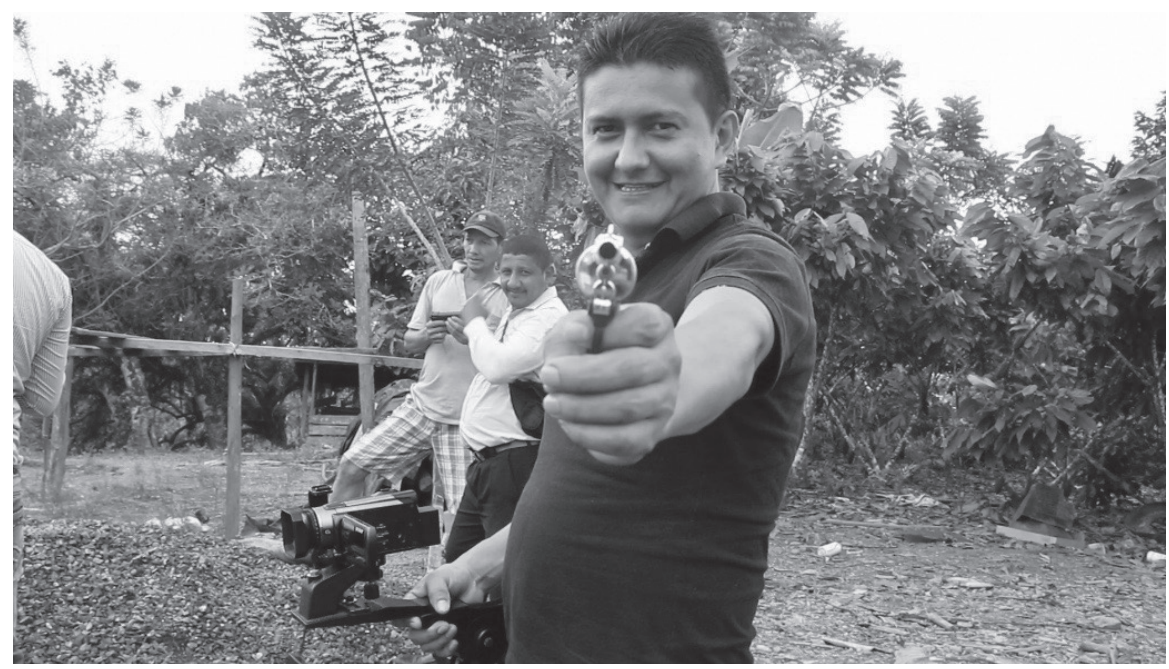

Exterior, segundo día de rodaje en la Manga del Cura (Manabí).

Fuente: Archivo fotográfico del autor (2016)

Estando claro el rol, la cámara dejó de ser un instrumento de observación y exploración y pasó a formar parte del método participativo y reflexivo etnográfico. Por ello, tanto etnógrafo como cámara se integraron en el desenvolvimiento natural de los productores informales y a las demandas del rodaje, aprovechando las circunstancias de interacción para intercambiar miradas e ideas de lo que se captaba. Un ejemplo (fotografía 2), es el hecho favorable en el que los productores informales, quienes ya familiarizados con las cámaras, interpelaban continuamente el lente del etnógrafo con su mirada y sus conversaciones, recursos que fueron aprovechados e incluidos en el documental como modos de intervención reflexiva entre productores y etnógrafo. Esta situación de colaboración no sesgo la mirada antropológica, al contrario, afianzó y generó espontaneidad en la correlación. El devenir de 
esta integración permitió el vínculo dialéctico entre la teoría adoptada y la realidad audiovisual capturada. Las comunicaciones favorecen tanto al dato audiovisual como al escrito que suscita el conocimiento antropológico, más cuando el etnógrafo se convirtió para la producción en experto teórico, técnico en maquillaje, fotógrafo, actor, camarógrafo e incluso publicista y vendedor de boletos del estreno de la narrativa audiovisual.

Durante la realización del rodaje etnográfico nos preocupa encuadrar, exponer, mediar e interactuar con los términos conceptuales enmarcados en las teorías antropológicas. Como resultado de estas preocupaciones surge la siguiente pregunta ¿cómo alcanzar la observación audiovisual rigurosa que demanda la disciplina antropológica? No existen fórmulas, procedimientos, rituales o técnicas específicas para lograr una veracidad audiovisual. Lo que sí existe es una rigurosa reflexión sobre el lugar de la mirada antropológica audiovisual que aporta nuevas posturas epistemológicas que devienen del modelo de trabajo de registro o captura, de la aproximación empírica, metodológica y teórica que se ha hecho frente al agente cultural estudiado. Esa aproximación forma la mirada analítica del etnógrafo sobre lo audiovisual, una mirada que busca describir con honestidad y vivacidad el evento filmado en su ambiente natural. Además, forma la postura del etnógrafo frente a lo que se captura con la cámara, bien sea provocado por la presencia de este o producido por la espontaneidad del agente cultural. Por ende, la rigurosidad científica se presenta durante todo el proceso de la investigación de la etnografía audiovisual. En las escenas etnográficas se ponen de manifiesto y se dinamizan los componentes conceptuales y cinematográficos. La observación y la participación detonan descripciones e interpretaciones de la cultura material investigada. Las conversaciones y las entrevistas estimularon memorias que, al relatarlas, hacen reaccionar emocionalmente a los productores informales frente a sus contextos de grabación.

La imagen (fotografía 3) presenta información sobre el proceso de rodaje de los productores informales, que resulta factible para esta y otras investigaciones. El lenguaje audiovisual adquiere su dato etnográfico significativo cuando su metodología y proceso de interacción entre etnógrafo, cámara y productor alcanza el objeto de su reflexión sobre la representación y sobre la imagen. $\mathrm{O}$, todo lo contrario, la representación puede ser cuestionada y renovada en cuanto su inmediata veracidad presente sesgos subjetivos frente a la realidad de los contextos estudiados. Por ello, durante esta investigación se alternaron dos técnicas de registro descriptivo para alcanzar una ob- 
servación rigurosa: la primera que sirve para el lenguaje escrito académico, fue anotar en la libreta de campo todo lo que ocurrió fuera del registro de la cámara, como la cotidianidad de las familias de los productores informales o las conversaciones que no se producían en los contextos de rodaje de la narrativa audiovisual, entre otros. Por ejemplo, una conversación familiar durante la cena, en la que se hace alusión al lugar en que fue asesinado el hermano de uno de los productores y que ahora formaba parte de su narrativa al ser el escenario de la primera muerte. Situación un poco tensa pero significativa porque develaba la importancia simbólica y propia del contexto para la memoria audiovisual de la narrativa. También, permitió obtener el dato representativo para el productor ya que la escena describe y presenta la destreza, la fuerza, el conocimiento del lugar y la venganza convertida en triunfo del personaje principal.

\section{Fotografía 3}

\section{El lugar de la mirada antropológica audiovisual}

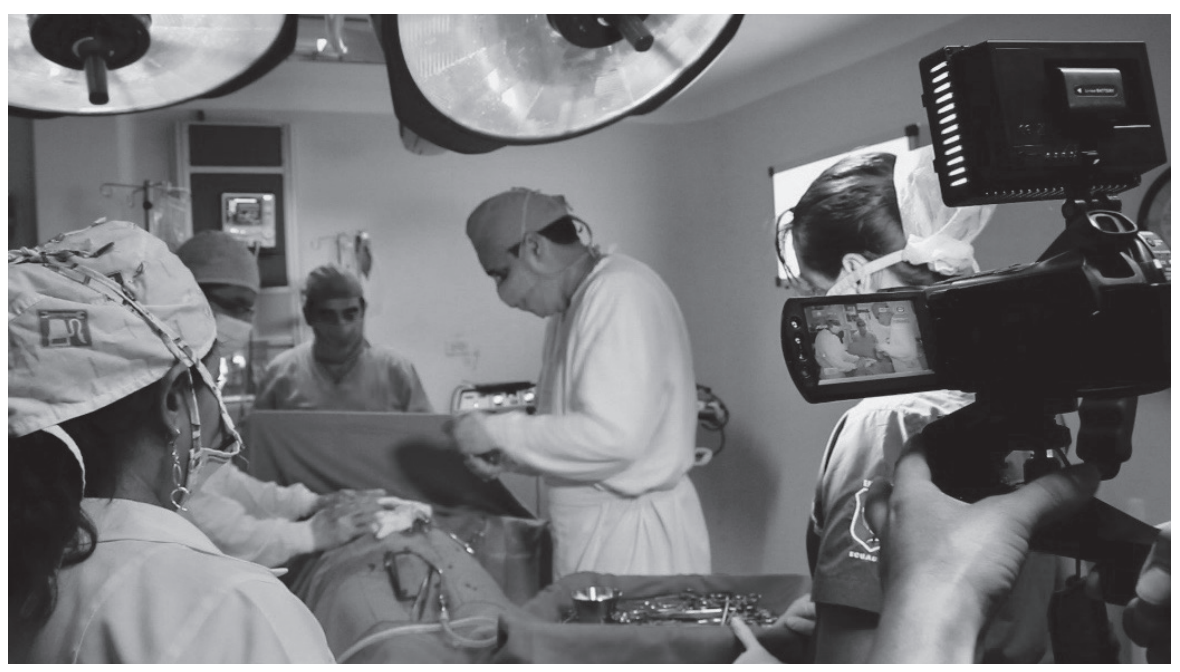

Interior Hospital escena extracción de proyectil, en Santo Domingo de los Colorados Fuente: Archivo fotográfico del autor (2014) 
Conocer el dato etnográfico significativo anterior fuera del contexto de rodaje potencia la segunda técnica descriptiva efectuada con la cámara, que como registro riguroso describe audiovisualmente cómo eran construidas las escenas y representadas en los contextos del rodaje. La descripción de la observación audiovisual en este estudio representa la mirada reflexiva entorno a contexto que evidencia la formalidad del "estar allî" etnográfico. Los dos lenguajes se complementan y generan detalles del dato etnográfico que se escapan al utilizar solo uno de los métodos de observación y descripción. De la misma manera, estas técnicas aportan material sustancial a la memoria de los productores informales en cuanto texto y audiovisual y, a la construcción científica del conocimiento antropológico audiovisual.

Todo dato que aporte información relevante (o genere sospecha de serlo) a la investigación durante el trabajo de campo está imbuido de dimensión significativa etnográfica. Como etnógrafos no podemos capturar en nuestras descripciones escritas o audiovisuales el acontecimiento universal del contexto, aprendemos a ser selectivos y esto nos lleva al dato significativo. Por lo tanto, el dato audiovisual capturado, representado y analizado en los procesos etnográficos se legitima significativamente gracias al tratamiento del concepto categórico en la teoría y su método de obtención. Otro ejemplo concreto en esta investigación es que uno de los productores informales utiliza en sus atuendos artísticos elementos étnicos de diferentes grupos indígenas nacionales. A primera vista, en la (fotografía 4) la flecha y el arco forman parte de la utilería y caracterización del personaje principal en la narrativa audiovisual. Al parecer este dato no debe transcender en el análisis, ya que se presenta de forma explícita en el personaje de Tarzán que representa. Pero cambia el significado cuando el instrumento es utilizado fuera del contexto de grabación como arma de caza y pesca, y allí donde el dato toma dimensión significativa cuando la utilización e interacción social de los elementos en la cultura materia del productor informal cumple otra función.

Ahora bien, ¿Cómo se tejen las imágenes en el lenguaje escrito y el lenguaje audiovisual con estos datos? Cuando hablamos de entrelazar lenguajes la mayor dificultad está en lo que queremos dar a conocer. Por ello, hay que saber escoger las modalidades de las representaciones audiovisuales y escritas. En función de esta investigación el tejido entre lenguajes se presenta desde sus tres mundos: su vida en familia, su desempeño laboral y la producción audiovisual, los cuales suceden entre la fusión y funcionalidad de sus percepciones; espacios donde experimentan, escuchan, ven y leen las 
historias que luego narran y representan audiovisualmente. El lenguaje audiovisual se encargaría de poner en evidencia rigurosa las complejidades de los diálogos, discontinuidades e interacciones cotidianas, mientras el lenguaje escrito expondría las interpretaciones, descripciones y análisis.

\section{Fotografía 4}

Significación del dato etnográfico

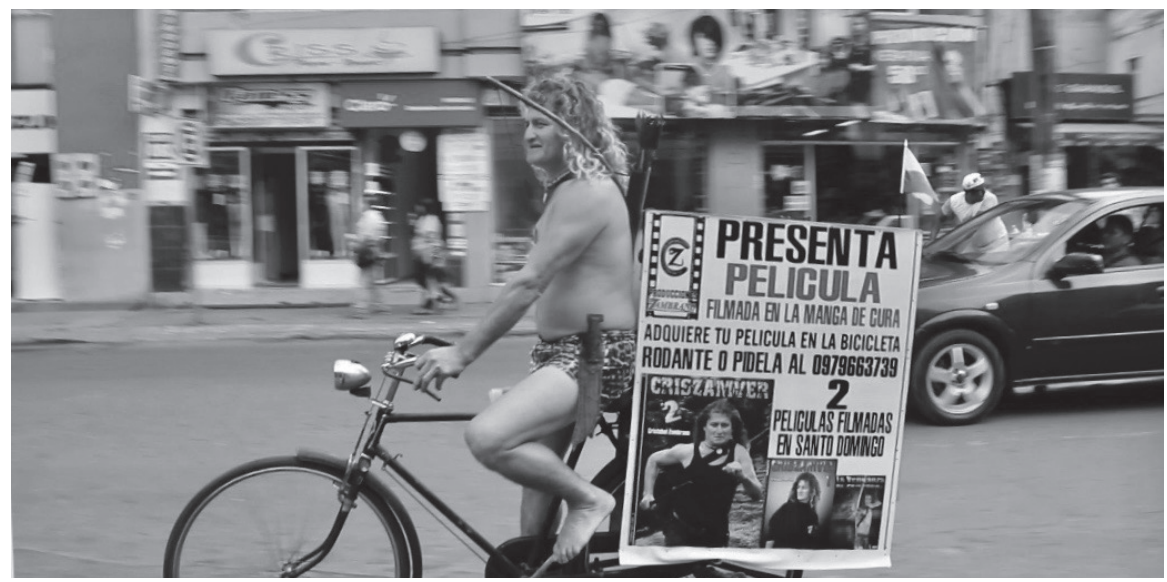

Exterior, Calle 29 de mayo, escena comercialización narrativas audiovisuales formato DVD, en Santo Domingo de los Colorados

Fuente: Archivo fotográfico del autor (2017)

Unas de las complejidades del tejido del lenguaje audiovisual y por ende en la producción informal se presenta frente al tiempo y el espacio que son factores fundamentales. Por ejemplo, el tiempo en una escena se convertía en aliado cuando la improvisación fluía entre los actores naturales o en un enemigo cuando se requería repetir varias veces la misma escena. El espacio de rodaje dependía de los propietarios de los lugares donde se graban las escenas, debido a que los productores solo pueden ejecutar el rodaje el día que el escenario esté disponible. Además, estos espacios y tiempos están sujetos a emociones contradictorias por parte de los dueños de los espacios y/o los familiares de los productores. Podía suceder que al día siguiente del rodaje el propietario del lugar puede retraer su autorización y prohibir la continuidad de la escena. Esto se presenta por diversas circunstancias del imagina- 
rio estereotipado hacia algunos actores ocasionales de parte de algunos propietarios. Por ello, los productores informales durante el rodaje de la escena revisan una y otra vez el material audiovisual para estar seguros y procurar no volver al lugar de rodaje. Asimismo, este ejercicio propuesto por los productores ahorra trabajo durante la etapa de edición y permite liberar espacio de memoria de la cámara.

\section{Fotografía 5}

\section{Tejiendo imágenes "in situ"}

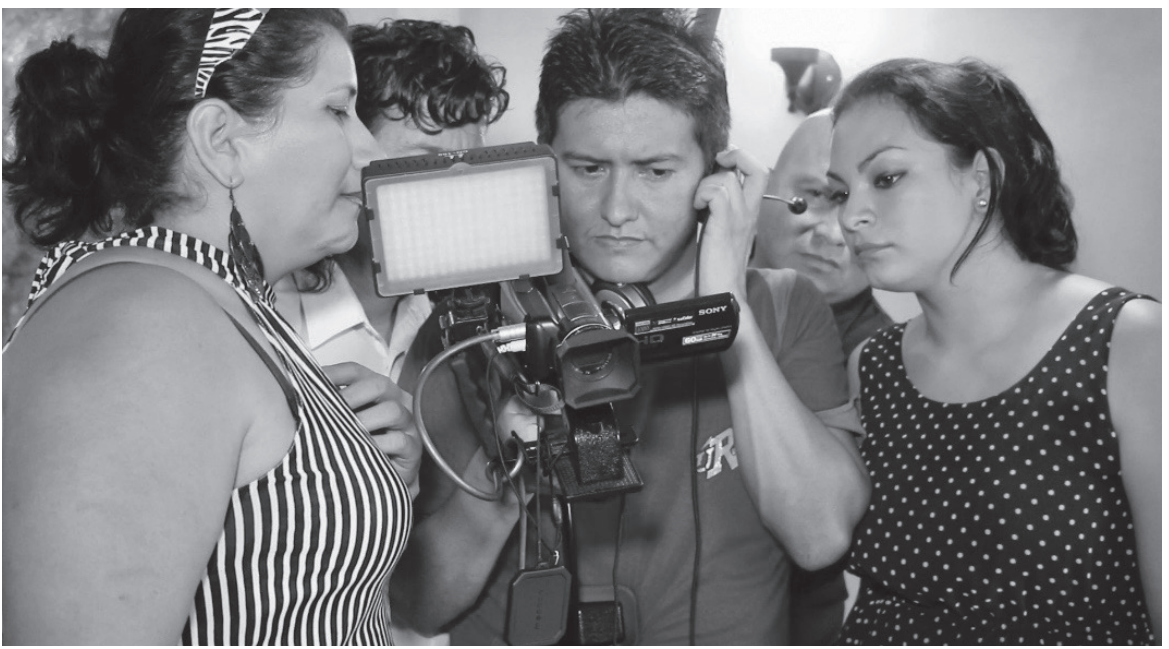

Exterior, restaurant, escena muerte de Pedro David en Santo Domingo de los Colorados Fuente: Archivo fotográfico del autor (2015)

Para el etnógrafo, la (fotografía 5) muestra, por una parte, la actividad del tejido audiovisual y por otra, hace alusión a la metáfora del recolector debido a que los productores informales desechan in situ las imágenes no deseadas. Tanto productor informal como etnógrafo audiovisual se convierten en recolectores de imágenes que luego tejerán para dar orden lógico a sus tejidos audiovisuales. A partir de este tapiz se puede analizar, en primer lugar, el complejo entramado entre cultura material, cotidianidad familiar, laboral y desempeño del productor informal representado en el tejido audiovisual. En segundo lugar, el tapiz nos permitió entender las percepciones, disponibilidades, posturas y destrezas de los productores informales frente a 
las necesidades de sus realizaciones audiovisuales. Este punto fue de mucha ayuda durante la retroalimentación y reflexión del trabajo realizado, porque permitió al etnógrafo entender las posiciones de los productores informales y así evitar prejuicios en la búsqueda de rigor científico. Además, proporcionó significado a elementos de este tejido que se pensaron poco importantes. Por último, el tejido audiovisual experimentado con los productores informales, terminó siendo un proceso de aprendizaje para el etnógrafo porque amplió la mirada de la descripción audiovisual y escrita al vincular el conocimiento antropológico con el conocimiento empírico del productor.

\section{Fotografía 6}

\section{Espacios-tiempos limitados}

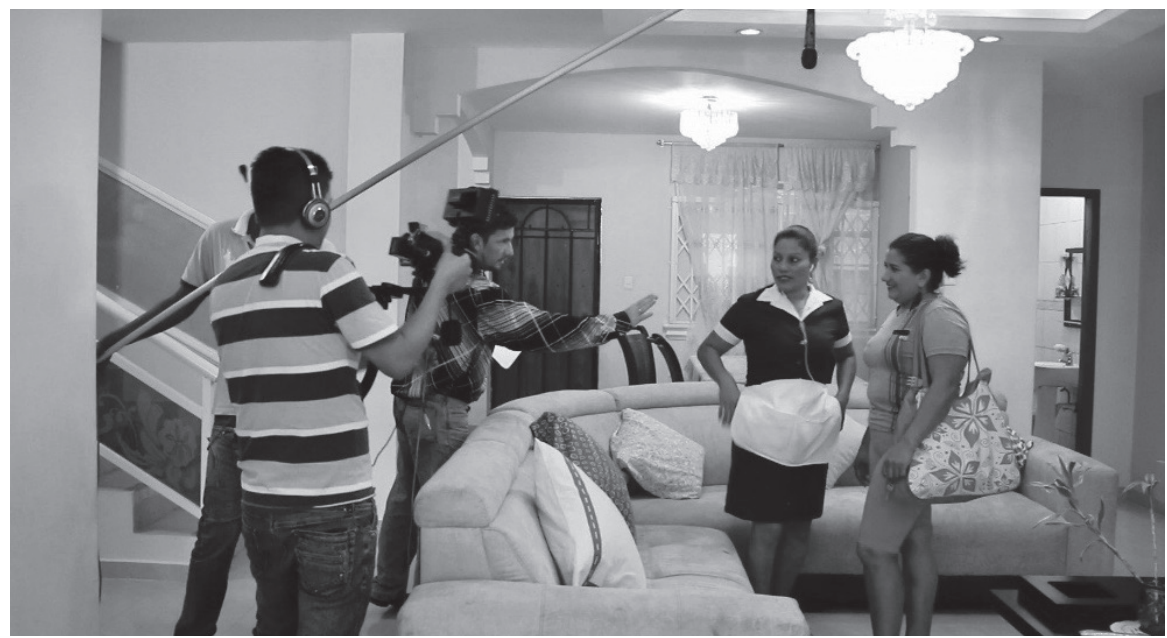

Interior, casa, escena discusión con auxiliar de limpieza en Santo Domingo de los Colorados Fuente: Archivo fotográfico del autor (2015)

La (fotografía 6) presenta tiempos y espacios limitados a su realidad inmediata. El tejido fuera del cuadro es aquello que describe el etnógrafo de forma escrita. Por ejemplo, el rodaje de la escena se ve interrumpido porque el celular del propietario de la casa ha desaparecido de la mesa del comedor. Del grupo de actores naturales hay varios señalados, el director enojado y en voz alta pide que aparezca el celular. Esta situación no aparece en el documental etnográfico por decisión ética ante los productores informales por 
la incomodidad del hecho. Pero forma parte de las costuras que el tejido audiovisual va dejando para otro tipo de lenguaje como el escrito. La observación, participación y reflexión que se mantiene junto al quehacer de los productores informales amplía y enriquece los datos etnográficos. Por ello, esta metodología nos acerca a sus percepciones de la realidad y nos permite, desde la descripción etnográfica escrita, repensar el dato etnográfico y ubicar nuevos significantes durante el desarrollo de la investigación. Finalmente, la etnografía audiovisual permitió recapitular, detallar y sintetizar la realidad observada durante el proceso del tejido.

\section{Postproducción}

\section{Entre edición, discusión}

No es tarea fácil sintetizar durante la edición en secuencias cortas el espacio temporal audiovisual del trabajo etnográfico. Es en este proceso donde las costuras audiovisuales traducidas en pequeños bloques de imágenes en movimiento, tienen que coincidir conceptualmente con los objetivos de investigación. El material audiovisual etnográfico sin edición es consustancial a la descripción escrita en el cuaderno de campo debido a que ambos se editan para su presentación científica. Este trabajo de enlace audiovisual puede realizarlo el etnógrafo de forma independiente tal como lo hace en el lenguaje escrito. Sin embargo, Jean Rouch (1995) proponía (antes de la era digital) que el edición debe ser realizada por un montajista que no haya participado en el rodaje. Hoy en día, gracias a las facilidades que brinda el software portátil de edición no lineal, podemos tener un primer borrador de nuestro trabajo audiovisual como en todo escrito, para posteriormente trabajar de la mano con un montajista experto, si así se desea. De acuerdo con esto "el proceso de montaje de un filme etnográfico equivaldría al proceso de escritura etnográfica, y la película montada no sería otra cosa que una monografía etnográfica expresada en imágenes y sonido" (Roca i Girona, Comp. \& D’Argemir, 2010, p. 192).

El montaje de esta investigación se realizó en tres fases. En la primera, el etnógrafo audiovisual propuso un borrador que se presentó a las productoras informales para su análisis. El objetivo era garantizar que tanto la mirada antropológica como de los productores fuese validada y aceptada en la narrativa audiovisual en la que ellos se representan y son representados, lo que permi- 
tió obtener la autorización del uso de sus imágenes y el derecho de difusión. La segunda fase tenía como objetivo evaluar la narrativa audiovisual; es decir, revisar la coherencia de las secuencias, comprobar si era entendible o no los objetivos teóricos planteados y analizar aspectos técnicos en cuanto a sonidos e imágenes. Para ello, se recibió la retroalimentación de los tutores de la investigación y de personas de otras disciplinas que, con su mirada brindan nuevos elementos al conocimiento y a la labor etnográfica. En la última fase se trabajó con un montajista de la línea de investigación antropológica con quien se compactó técnicamente el material para futuras visualizaciones.

La experiencia colaborativa entre el etnógrafo y los productores informales ayudó en la búsqueda por alcanzar los objetivos que se reflejan en el registro, el análisis y las reflexiones existentes desde el trabajo de campo hasta la realización del documental final. Por ende, para esta investigación, el espaciotiempo representado en el lenguaje audiovisual alcanza el mismo valor científico frente al tratamiento del dato etnográfico del lenguaje escrito.

\section{Consideraciones sobre el documento etnográfico audiovisual}

El registro etnográfico audiovisual desde sus comienzos ha permitido describir y conservar hechos memorables de tiempos y espacios que el lenguaje escrito no había podido contener. Esta consideración se argumenta por el trabajo de etnógrafos audiovisuales como Jean Rouch, David MacDougall, Roger Canals, Carmen Guarini, y todos aquellos que utilizan el medio de la antropología visual para expandir sus reflexiones.

El avance tecnológico ha permitido posicionar la cámara como dispositivo integral de transformación en la práctica antropológica en tanto diseño metodológico, teórico y en la construcción de conocimientos. El documento audiovisual nos obliga a repensar el dato etnográfico, no tanto por los agentes culturales, sino por la participación del nosotros. Por ello, durante el desarrollo etnográfico se pudo evidenciar que los procesos de colaboración e interacción generados por el dispositivo audiovisual posibilitaron dimensiones menos abstractas y más próximas a la vida social de los productores informales.

Durante el trabajo de campo se buscaba que el uso de la cámara accionara el diálogo, la interacción y la reflexión entre etnógrafo audiovisual y los productores informales. Esta consideración viene dada por Rouch frente a la "distancia justa o la justa distancia", cuando se trata de construir una nueva verdad (1995). Verdad que permite entender el vínculo dialéctico entre la teoría adoptada y la realidad audiovisual capturada. De este proceso 
se logró por un lado la disposición de los sujetos, en tanto como querían ser representados evidenciando la "fidelidad y factibilidad" del dato etnográfico (Grau Rebollo, 2008). El texto audiovisual por su parte genera el tercer elemento como lo es espectador quien vuelve a interpretar.

Por ello, podemos considerar que el documento audiovisual también posibilitó al productor informal construir una idea sobre sí mismo, una representación que ayudó a devolver esa mirada extraña hacia el etnógrafo y posiblemente al futuro espectador del registro. El cruce de miradas desvanece la posibilidad de exotismo que puedan generarse durante la interacción, es aquí donde podemos experimentar el traspase de conocimientos que desmantela y revela otras formas de construcción epistemológicas dentro de la disciplina antropológica. Estas consideraciones nos dejan con la reflexión de que cuando decidimos registrar la realidad esta se impone con sus interminables caminos bifurcados compuestos por innumerables piezas que construyen ese entramado llamado sociedad. Allí entre ese cruce de miradas etnográficas y empíricas aparece en toda su magnificencia la proximidad de una captación cierta de lo humano entre productor informal y etnógrafo.

Por último, y no menos importante, debemos reflexionar y considerar sobre los espacios negados para la divulgación de los documentos audiovisuales, ya que el texto escrito goza de diversos sitios de divulgación científica, pero la academia aún sigue en deuda frente a los espacios que valoren el rigor científico del texto audiovisual. Por ello, es imperante considerar la necesidad de generar plataformas más cercanas a los agentes culturales y a los espectadores, para así seguir en una red de correspondencia, ya que estos aportes amplían la reflexión teórica de la Antropología Audiovisual, generando nuevas miradas críticas que permiten revisar y reformular métodos y teorías ya abordadas, además de proponer, desde diversas redes otros caminos de producción de conocimientos.

\section{Bibliografía}

Andrade, X., \& Zamorano, G. (2012). Antropología visual en Latinoamérica (Dossier $)=$ Visual Antropology in Latin America. Iconos: Revista de Ciencias Sociales. Antropología Visual en Latinoamérica, 42(13901249), 11-16. Quito: FLACSO Sede Ecuador. 
Ardèvol, E. (1994). La mirada antropológica o la antropología de la mirada: De la representación audiovisual de las culturas a la investigación etnográfica con una cámara de video. Universidad Autónoma de Barcelona.

Ardèvol, E. (1998). Por una antropología de la mirada: etnografía, representación y construcción de datos audiovisuales. Revista de Dialectología y Tradiciones Populares (c) Consejo Superior de Investigaciones Científicas, Licencia Creative Commons 3.0 España (by-Nc), 35 (2), 217-240. Retrieved from http://rdtp.revistas.csic.es/index.php/rdtp/article/viewFile/396/400

Ardèvol, E., \& Estalella, A. (2010). Internet: instrumento de investigación y campo de estudio para la antropología visual. Revista Chilena de Antropología Visual, 15, 1-21. Retrieved from file://Users/jorgegraurebollo/Documents/ Papers2/Articles/2010/Estalella/Revista Chilena de Antropologia Visual/ Revista Chilena de Antropologia Visual 2010 EstalellaInternet instrumento de investigacion y campo de estudio para la antropologia visual.p

Ardèvol, E., \& Pérez Tolón, L. (1995). Tendencias teóricas y metodológicas en el cine etnográfico, en imagen y cultura. Perspectivas del cine etnográfico. (L. Ardévol, E., \& Pérez Tolón, Ed.) (1pr ed.). Granada, España: Diputación Provincial de Granada. Retrieved from https://www.academia. edu/7527342/Elisenda_Ardévol_y_Luis_Pérez_Tolón_eds._Imagen_y_ cultura._Perspectivas_del_cine_etnográfico._Diputación_de_Granada_ Biblioteca_de_Etnología_núm._3_Granada_1996_422_pp

Asch, T., \& Asch, P. (1995). Film in Etnographic Research. Principles of Visual Anthropology. En P. Hockings (Ed.), Visual Anthropology (pp. 335-360). Berlin; New York: Mounton de. 2 ed.

Boudreault-Fournier, A., Caiuby Novaes, S., \& Gitirana Hijiki, R. S. (2017). Fabricar o Funk em Cidade Tiradentes, São Paulo: performance em etnoficção. doi:http://revues.mshparisnord.org/cultureskairos/index.php?id=1441.

Caiuby Novaes, S. (1993). Jogo de Espelhos. Imagens da representação de si através dos outros. (Universidade de São Paulo-USP, Ed.) (Primera.). São Paulo. Retrieved from http://bd.trabalhoindigenista.org.br/?q=tese/jogo-de-espelhos

Canals i Vilageliu, R. (2011). Jean Rouch un antropólogo de las fronteras. Revista Digital Imagens Da Cultura/Cultura Das Imagens, 1, 63-82. Retrieved from http://revistes.ub.edu/index.php/contextos/article/view/2145

Capdevielle, J. (2011). El concepto de habitus: "Con Bourdieu y Contra Bourdieu." Anduli: Revista Andaluza de Ciencias Sociales, 10, 31-45. Retrieved from https://dialnet.unirioja.es/descarga/articulo/3874067 
Cárdenas, C., \& Duartes, C. (2011). Etnografía audiovisual: Instrumento para la divulgación de un conocimiento y técnica de investigación social. Colombia Nexus, 10 fasc.N/(1900-9909), 150- 171. doi:http://nexus.univalle. edu.co/index.php/nexus/article/view/1378

De Brigard, E. (1995). Historia del cine etnográfico. En Elisenda Ardévol, y Luis Pérez Tolón (Ed.), Imagen y cultura: perspectivas del cine etnográfico (Diputación, pp. 31-73). Granada, España.

Deleuze, G. (1984). La imagen-movimiento, Estudios sobre cine 1. (Paidos, Ed.) (Primera., Vol. 1). Buenos Aires [etc] :

González, G. P. (2011). Tu mira la foto, pero no se la enseñes a nadie. Análisis de una práctica fotográfica, los discursos y las representaciones de niños y adolescentes en el contexto de talleres de fotografía participativa. Dos estudios de caso. Universitat Rovira i Virgili. Retrieved from http://www.tdx. cat/handle/10803/51883

Grau Rebollo, J. (2002). Antropología audiovisual: fundamentos teóricos y metodológicos en la inserción audiovisual en diseños de investigación social (Bellaterra). Barcelona, España: Edicions Bellaterra.

Grau Rebollo, J. (2005). Antropología, cine y refracción. Los textos filmicos como documentos etnográficos. Gazeta de Antropología, 21, 1-18.

Grau Rebollo, J. (2008). El audiovisual como cuaderno de campo en el medio audiovisual como herramienta de investigación social. Interculturales, Documentos CIDOB Dinámicas, 12, 13-29. Retrieved from https://dialnet. unirioja.es/servlet/autor?codigo $=1740038$

Guarini, C., \& De Angelis, M. (2014). Antropología e imagen Pensar lo visual (S. Soleil, Ed.) (Nanook). Ciudad Autónoma de Buenos Aires, Argentina.

Hine, C. (2004). Etnografía Virtual. Editorial UOC, Ed. (UOC). Barcelona España. Hockings, P. (2003). Principles of Visual Anthropology. (P. Hockings, Ed.) (third edit.). Berlín y Nueva York.: Mouton de Gruyter.

Lacerda, R. (2015). Cinema de Observação: o Olhar Autoral. Aniki : Revista Portuguesa Da Imagem Em Movimento, 2(1).

Lisón Arcal, J. C. (1999). Una propuesta para iniciarse en la Antropología visual. Revista de Antropología Social, 1(8), 15-35. Retrieved from http://dialnet.unirioja.es/servlet/articulo?codigo $=157919 \&$ orden $=1 \&$ info $=$ link

MacDougall, D. (1995). ¿De quién es la historia? En E. Ardevol \& L. Pérez (Eds.), Imagen y cultura: perspectivas del cine etnográfico (Biblioteca pp. 401422). Granada, España. 
Mardones, P., \& Riffo, R. (2011). Reflexionando de Antropología Audiovisual latinoamericana (No. 2). Alpaca producciones (Vol. 1). Buenos Aires, Argentina. Retrieved from http://www.alpacaproducciones.com.ar/Reflexiones sobre el estado de la.pdf

Mead, M. (1995). Visual Antropology in a Discipline of Words in Introduction: Principles of Visual Anthropology/edited by Paul Hockings. En Mounton de Gruyter (Ed.), Principles of Visual Anthropology 2nd ed. (pp. 3-10). Berlin, New York.

Mélice, A. (2009). Un concept lévi-straussien déconstruit : le bricolage. Les Temps Modernes, 656(5), 83-98. doi:10.3917/ltm.656.0083

Nichols, B. (1997). La representación de la realidad : cuestiones y conceptos sobre el documental. Barcelona [etc.] : Paidós. Retrieved from http://cataleg. uab.cat/record=b1395115 S1*cat

Piault, M. H. (2002). Antropología y cine. (C. Madrid, Ed.) (Edición pr.). Madrid, España. Retrieved from http://cataleg.uab.cat/record=b1560312 S1*cat

Pink, S. (2003). Interdisciplinary agendas in visual research: re-situating visual anthropology. Visual Studies, 18(2), 179-192. Retrieved from http:// www.tandfonline.com/doi/abs/10.1080/14725860310001632029

Potts, R. (2015). A Conversation with David MacDougall: Reflections on the Childhood and Modernity Workshop Films. Visual Anthropology Review, 31(2), 190-200. doi:10.1111/var.12081

Robles Picon, J. I. (2012). El lugar de la Antropología Audiovisual: espacios profesionales y metodologías participativas. Íconos. Revista de Ciencias Sociales, 44, 147-162. doi:10.17141/iconos.44.2012.343

Roca i Girona, J., (Comp.), J. J. P., \& D’Argemir, D. C. (2010). Fotografía, dibujo y grabaciones audiovisuales. En UOC (Ed.), Etnografía (pp. 171-192). Barcelona, España.

Rose, G. (2007). Visual methodologies an introduction to the interpretation of visual materials (2d ed.). London-Thousand Oask-New Delhi: Sage Publications.

Rouch, J. (1995). The Camera and Man. En P. Hockings (Ed.), Principles of Visual Anthropology (pp. 79-98). Mounton de Gruyter: Berlin, New York.

Ruby, J. (2007). Los últimos 20 años de Antropología visual-una revisión critica. Revista Chilena de Antropología Visual, 9(3)(0718-876), 13-36. Retrieved from http://rchav.cl/imagenes9/imprimr/ruby.pdf

Vaca, P. J. P. (2015). Chonewood: Etnografía, Cine popular y asesinato por encargo en Chone. Quito: FLACSO. 


\section{Películas}

Crónica de un Verano (1961) Dirección Jean Rouch y Edgar Morín; duración 85m Meykinof (2005) Dirección Carmen Guarini; duración 60m

Gandhi’s Children (2008), Dirección David MacDougall; duración 3h 55m

Los espigadores y la espigadora (2000) Dirección Agnès Varda; duración 82m

Fecha de recepción: 08/06/2017; fecha de aceptación: 22/07/2017/;

fecha de publicación: 01/09/2017 



\title{
Los primeros viajes audiovisuales (1936) de Rolf Blomberg en Ecuador
}

\author{
The first audio-visual journeys (1936) \\ of Rolf Blomberg in Ecuador
}

\author{
Franco Passarelli ${ }^{1}$ \\ fpassarelli16@gmail.com
}

\begin{abstract}
Resumen
El objetivo del presente artículo es indagar, a partir del análisis comparativo de los filmes "En Canoa a la Tierra de los Reductores de Cabezas" y "Vikingos en las Islas de las Tortugas Gigantes" de Rolf David Blomberg (Suecia, 1912- Ecuador, 1996), la producción y reproducción de imágenes de exploradores europeos en Ecuador durante la época de entre-guerras (1919-1939). El trabajo se centra principalmente en el análisis de la forma fílmica de ambas películas donde se pretende poner en discusión la construcción de "viajes audiovisuales". Tiempo, espacio y sujeto quedan desajustados en diferentes niveles como conclusiones del análisis comparativo. Las preguntas que van a guiar este trabajo son ¿Qué tipo de narrativas e imaginarios construyeron los "viajes audiovisuales" de los exploradores/realizadores europeos en Ecuador? ¿Cómo circulaban esas ideas? ¿Cuál es la importancia de estudiar las imágenes- movimiento de este tipo de exploradores/realizadores desde y para la Antropología Audiovisual?
\end{abstract}

\section{Palabras clave}

Rolf Blomberg, viajes audiovisuales, crónica de exploradores, representación, antropología audiovisual.

Forma sugerida de citar: Passarelli, Franco (2017). Los primeros viajes audiovisuales (1936) de Rolf Blomberg en Ecuador. Univeristas, XV(27), pp. 117-135.

1 FLACSO- Ecuador. Orcid: 0000-0002-3582-8102. 


\begin{abstract}
The objective of this article is to investigate, from the comparative analysis of the films "In Canoe to the Land of the Reductors of Heads" and "Vikings in the Islands of the Giant Tortoises" of Rolf David Blomberg (Sweden, 1912- Ecuador, 1996), the production and reproduction of images of European explorers in Ecuador during the interwar period (1919-1939). The work is mainly focused on the analysis of the film form of both films where the construction of "audio-visual trips" is intended to be discussed. Time, space and subject are left unadjusted at different levels as conclusions of comparative analysis. The questions that will guide this work are: What kind of narratives and imaginaries constructed the "audiovisual journeys" of European explorers / filmmakers in Ecuador? How did these ideas circulate? What is the importance of studying the movement images of this type of explorers / directors from and for Audiovisual Anthropology?
\end{abstract}

Keywords

Rolf Blomberg, audiovisual journeys, chronicles of explorers, representation, audiovisual anthropology.

\title{
Introducción
}

El presente trabajo propone un análisis fílmico acerca de la producción de imágenes- movimiento realizadas por exploradores europeos en Ecuador durante la época de entre-guerras (1919-1939). Las películas que se van a analizar son "En Canoa a la Tierra de los Reductores de Cabezas" (Rolf Blomberg, 1936) y "Vikingos en las Islas de las Tortugas Gigantes" (Rolf Blomberg, 1936). Ambos filmes construyen un "viaje audiovisual" (concepto propuesto por este artículo) a partir de la representación y de la narrativa, donde se destaca el desplazamiento espacial y temporal de los sujetos filmados.

Si bien este trabajo sólo se detiene en dos producciones de un mismo autor, se intenta proponer un modelo de análisis que pueda ser útil en otras investigaciones sobre exploradores e imaginarios. La metodología, extraída de los estudios principalmente de las artes audiovisuales, resulta útil para el campo de la Antropología Audiovisual ya que nos permite (re)conocer formas e imaginarios en el análisis audiovisual. La forma fílmica de una película documental/etnográfica, siempre está determinada por la mirada del realizador. Por lo tanto, el 
análisis de la misma, en la construcción de los "viajes audiovisuales", da cuenta de imaginarios visuales que se producen y reproducen a partir de las imágenes.

\section{Representaciones e imaginarios en las crónicas de exploradores en Ecuador, a principios del siglo XX}

En el período de entre-guerras (1919-1939) el Estado ecuatoriano estaba en un proceso de "modernización", por lo que los migrantes europeos como Rolf Blomberg ${ }^{2}$, Paul Rivet ${ }^{3}$, el Marqués de Wavrin ${ }^{4}$ y el padre Crespi ${ }^{5}$ eran bien aceptados en función de la idea de "progreso". Los extranjeros, que se relacionaban con los grupos de poder, llegaban a buscar lo diverso, lo distinto, llevado hasta el extremo de lo exótico (Giordano y Gustavsson, 2013 , p. 42). Vale aclarar que cada uno tenía su proyecto particular: Rivet hacía estudios etnográficos para contribuir a la incipiente disciplina antropológica, Crespi pretendía dar a conocer las tareas evangelizadoras en la Amazonía y Blomberg, al igual que Wavrin, buscaba el éxito comercial de sus

2 Rolf David Blomberg nació en 1912 en Estocolmo, Suecia. Llegó a Ecuador por primera vez en 1934 y luego regresó en 1936 par filmar las dos películas que son objeto de estudio de este artículo. Su perfil es de un hombre polifacético: fue naturalista, realizador audiovisual, fotógrafo, caricaturista, escritor, periodista, pero principalmente, explorador. Murió en 1996 en Ecuador.

3 Médico militar de formación, luego arqueólogo y etnógrafo francés, llegó a Ecuador en 1901 bajo la Segunda Misión Geodésica Francesa. Llevó a cabo estudios de la industria material, de lingüística y tecnología, alejándose de los estudios antropométricos que caracterizaban a la incipiente disciplina antropológica en ese momento. Su corriente teórica fue el difusionismo, que bajo la idea de que no hay culturas superiores ni inferiores, los cambios en ellas se deben al contacto. Paul Rivet fue uno de los creadores del Museo del Hombre de París en 1938. Además, inclinado políticamente al socialismo, fue diputado y su carrera de investigación siempre intentó ligar lo político con lo científico (Lauriére, 2010).

4 El Marqués de Wavrin fue un hombre de la nobleza belga que desde 1913 realizó expediciones por Sudamérica filmando numerosas películas. La más conocidas fueron: En el corazón de América del Sur desconocida (1925), Entre los indios hechiceros. Los indios del Gran Chaco (1925), Las cataratas del Iguazú (1925), La América exótica (1926) y Au pays du scalp (En el país de los cazadores de cabezas) (1931). Esta última fue la que tuvo mayor éxito en la época e intentaba mostrar la vida de los "Jíbaros" a partir de las reseñas que había hecho el aventurero estadounidense Fritz Up de Graff (Guarín, 2012).

5 Carlos Crespi Croci fue un sacerdote cristiano de la escuela salesiana. Nació en Italia y en 1923 llegó a Ecuador como organizador de una exposición de objetos arqueológicos. Crespi tenía el perfil de hombre polifacético, como todos los exploradores que estamos viendo: hizo estudios botánicos, faunísticos, geológicos y etnográficos. Filmó a los "Jíbaros" en sus viajes por la selva y así fue que realizó los "Los Invencibles Shuaras del Alto Amazonas" (1927), película de gran éxito en la época.

6 La incorporación de los extranjeros en la sociedad nacional ecuatoriana se dio a través de las clases medias-altas que veían con "buenos ojos" la llegada de gente europea. "Por sus orígenes y formación de clase media o alta, los viajeros compartían muchos de los supuestos de la clase terrateniente ecuatoriana que se orientaba hacia Europa" (Fitzell, 1994, p. 37). 
filmes. Si bien sus proyectos eran diferentes, su principio cognoscitivo era similar: "discutir acerca de las diferencias y similitudes que tienen las culturas indígenas respecto de la civilización occidental” (León, 2010, p. 118). En sus viajes, buscaban vivir y compartir experiencias con "otras culturas", escapando de una Europa colapsada por las guerras y desesperanzada por el destino de la humanidad. Ecuador como destino alejado y exótico, circulaba como imaginario en Europa y por lo tanto los países del Viejo Continente enviaban informantes para documentarlo.

Rolf Blomberg no era ajeno a esto y, como señala Gonzalo Vargas (2013, p. 118) él cumplirá el rol de "el nuevo explorador/colonizador europeo, quien viajará a los territorios desconocidos de la América salvaje e indómita para los ojos de Occidente (...) Estos viajes se dan en función de catalogar, clasificar y archivar..." a los diversos modos de vida, entendidos como "cultura", dentro de la Antropología y el cine. Surge el problema entonces de cómo representarlos. María Luisa Ortega (2003, p. 96), al caracterizar a estos "exploradores/colonizadores" del período de entre-guerras, afirma que la "fascinación etnográfica" sobre lo "primitivo" y lo "salvaje" es uno de los grandes componentes del proceso de producción y por lo tanto de la construcción narrativa y representativa de los viajes audiovisuales en las crónicas de los exploradores. "Pero además la suerte de taxidermia que el cine etnográfico y étnico del momento operaba sobre las culturas representadas, y que contagiaba toda obra de documental o de ficción, se enfrentaba a la representación del Otro en busca de representar sus esencias (...)" (Ortega, 2003, p. 98). Se trata entonces de deshistorizar, aplicando el modelo de "taxidermia" (seguir viendo como vivo algo que está muerto) a lo etnográfico (Rony, 1996). Por lo tanto, desde este modelo de construcción representativa, se intentan "borrar las supuestas impurezas de cambio cultural, y con ello eludir la realidad del contacto cultural, la colonización y el proceso histórico" (Morris, 1996, p. 64, en: Griffiths, 2002 , p. 305, traducción nuestra). Esto último se relaciona directamente con el modelo de "etnografía de salvataje", propuesto por James Clifford (1999), donde se entendía que las culturas "prístinas" estaban en peligro de extinción y por lo tanto había que registrarlas antes de que se pierdan.

Dicho registro debía ser mimético (Bordwell, 1996; Suhr y Willerslev, 2012), paradigma característico de principios del siglo XX. Dentro de este paradigma se piensa a la representación como copia fiel de la realidad. De esta forma, se nos hace creer que no hay diferencia entre lo que vemos en pantalla y lo que le sucedió en concreto al realizador (experiencia). El paradigma mimé- 
tico marca una relación de 1 a 1 entre representación y realidad, dando cuenta de principios positivistas en su forma de entender el mundo. En síntesis, se pensaba que el registro de las culturas en extinción, es el reflejo de la realidad.

A nivel regional, uno de los exploradores que realizó numerosas filmaciones en Latinoamérica fue el Marqués de Wavrin. Según M. L. Ortega (2003), él es un claro ejemplo de cómo estos viajeros buscaban los ritos primitivos y el salvataje de las prácticas en extinción, pero sin adoptar una postura paternalista y romántica. Sus películas fueron un gran éxito comercial y fue reconocido en todo el mundo por sus viajes. Otro extranjero que estuvo por estas tierras fue Paul Rivet, que con sus fotos, marcó una tendencia en los estudios de la época (Guarín, 2012). La fotografía antropométrica que realizó en las zonas de Tulcán, Riobamba, Saraguro y Santo Domingo se distanciaba, en parte, de los estudios positivistas que dominaban la incipiente disciplina antropológica (Troya, 2012). Los trabajos de Rivet sólo circulaban en ambientes académicos. Rivet y Wavrin eran amigos (Guarín, 2012, p. 185), lo que marca las redes de relaciones entre los exploradores y los antropólogos en esta etapa incipiente del cine documental y etnográfico.

A nivel local, si hacemos un sintético panorama de las tres obras fundacionales del cine ecuatoriano, vemos que se producen en la época recién descripta. Como bien señala León (2010, p. 93) "los primeros films rodados en el Ecuador que se conservan hasta la actualidad son también los primeros testimonios cinematográficos de los pueblos indígenas que conocemos”. Según León (2010, p. 93), las primeras filmaciones en Ecuador son: 1) las que pertenecen al Fondo Miguel Ángel Álvarez (1927- 1935); 2) Los invencibles Shuaras del Alto Amazonas (1927), del padre Carlos Crespi; y 3) Ecuador (1929) de Manuel Ocaña.

\section{Los viajes audiovisuales: espacio, tiempo y sujeto desde la forma fílmica}

Llamamos "viaje audiovisual" a la construcción fílmica de un espacio y un tiempo particular, en el cual el realizador se desplaza, y donde se encuentra con un sujeto (objeto para la época) "Otro". Se trata de una puesta en forma fílmica (Bordwell y Thompson, 1993; Cook, 1994) donde las herramientas audiovisuales escogidas por el viajero/realizador nos hablan de qué era lo que buscaba y cómo lo hacía, en síntesis, de su mirada (Ardèvol, 2006). Definimos al término "forma fílmica" como la selección de herramientas 
del leguaje audiovisual que emplea el realizador: tipo de plano, movimiento de cámara, tipo de lente, punto de vista ${ }^{7}$, punto de escucha ${ }^{8}$ y montaje, entre otros. En la conjugación de estos elementos, sumado al tipo de relación que el viajero/realizador estableció con los sujetos filmados, encontramos el modo de representación del filme (Ardèvol, 2006).

La elección de cada una de las herramientas mencionadas no es azarosa, y nos "dice" mucho acerca de la postura del viajero/realizador. La selección de un tipo de encuadre (conjugado con el resto de las herramientas del lenguaje audiovisual) crea diferentes sentidos a los espectadores. Estos sentidos, por lo tanto, son parte del "contenido" del filme (Metz, 2002 [1967]). En consecuencia, entendemos la relación forma/contenido como dialéctica, donde se hacen indistinguibles los límites entre uno y otro.

\section{Las películas}

Hemos decidido tomar como objeto de estudio las dos primeras películas que ha realizado Rolf Blomberg en Ecuador, "Vikingos en las islas de las tortugas gigantes" $\mathrm{y}$ "En canoa a la tierra de los reductores de cabezas"10, ambas filmadas en 1936, por varias razones. La primera es que ambos filmes no han sido proyectadas dentro de Ecuador, debido a que fueron producidas

7 Con el término punto de vista, desde la teoría del cine, me refiero a "Un emplazamiento, real o imaginario, desde el cual se produce una representación. Es un punto desde el cual un pintor que utiliza la perspectiva lineal organiza su cuadro; y también, en el cine, el punto imaginario, eventualmente móvil, desde el cual fue filmado cada plano" (Aumont y Marie, 2006, pp. 183-184).

8 Con el término punto de escucha, también desde la teoría del cine, aludo a desde dónde es encuadrado el sonido (Chion, 2011).

9 Vikingar på sköldpaddoarna

Vikingos en las islas de las tortugas gigantes

Dirección: Rolf Blomberg

Formato: $35 \mathrm{~mm}$

Duración: 10'25"

Año: 1936

Locación: Galápagos, Ecuador

(Fuente: Archivo Blomberg)

10 I kanot till huvudjägarnas land

En canoa a la tierra de los reductores de cabezas

Dirección: Rolf Blomberg

Formato: $35 \mathrm{~mm}$

Duración: 12' 5',

Año: 1936/ Locación: Amazonía, Ecuador (Fuente: Archivo Blomberg) 
exclusivamente para el público sueco, por lo que este artículo intenta rescatarlas del olvido. La segunda es con el fin de ver, cómo se insertaban este tipo exploradores en el "mundo" de los viajeros. Por último, poner el foco en ambas películas nos permite ir llenando de a poco el vacío que existe sobre la historia del documental etnográfico ecuatoriano, dando a conocer nuevos referentes que sean objeto de análisis de futuras investigaciones tanto en Antropología como en Antropología Audiovisual y en Artes Audiovisuales.

La primera película, realizada en las Islas Galápagos, narra cómo viven los inmigrantes nórdicos en un contexto "extraño". El realizador focaliza en las distintas familias (noruegas, suecas e islandesas) que viven en las Islas y que sirven como eje articulador de la película para narrar cómo es la vida allí. El filme muestra las actividades cotidianas de los lugareños, cómo recolectan frutos y raíces de las plantas, cómo producen azúcar de la caña y cómo cazan animales. A partir de esta construcción de la cotidianidad el realizador intenta demostrar que las familias son autosuficientes en el "extraño" paisaje de las Islas.

La segunda, describe el modo de vida "jíbaro" (hoy shuar) y se centra en la tzanza (cabeza reducida). El personaje principal de la película es Henry Nielsen, un aventurero danés que se dirige con un equipo de exploración a las "tierras jíbaras". La película muestra las actividades cotidianas de la comunidad indígena, donde aparecen la preparación de la chicha, la caza con cerbatana y la fabricación de artesanías. Además, hay momentos donde aparece el contacto entre Henry Nielsen y la comunidad, a través de los festines e intercambios de objetos. En esta película el relato se inicia con los preparativos del viaje a la comunidad selvática, principalmente con la fabricación de la canoa. La travesía hacia el destino (la comunidad jíbara) es dificultoso y dramático. El final de la película tiene la misma construcción narrativa.

\section{Análisis comparativo: la construcción del viaje audiovisual en ambas películas}

Al establecer una comparación en la construcción de los viajes audiovisuales de las películas "Vikingos en las islas de las tortugas gigantes" (1936) y "En canoa a la tierra de los reductores de cabezas" (1936), encontramos similitudes y diferencias. A continuación vamos a desarrollar sintéticamente los puntos en común:

El eje formal que utiliza Blomberg en ambas películas es la construcción de mini-secuencias. Por el lado de "En Canoa..." cada una de las mini-secuen- 
cias (que se corresponden con las escenas) narran diferentes actividades de la comunidad, que tienen que ver con la preparación de los alimentos, con la fabricación de armas y cerámica, con los juegos, con los animales, los niños y los intercambios de objetos. En la mayor parte de las escenas aparece la figura de Henry Nielsen como disparador de situaciones, lo cual es un rasgo de interactividad (catalización de una situación a partir de la puesta de cámara). Ejemplo de ello es cuando él le enseña la cámara de fotos a los niños (ver Figura 1), o cuando le indica a un joven que dispare con la cerbatana. La construcción de mini-secuencias, atravesadas por Henry Nielsen en su relación con la comunidad, es el eje formal de la película. Del mencionado eje de análisis distinguimos sub-ejes que lo sostienen: la construcción del viaje dramático, el retrato del modo de vida, lo lúdico, la interactividad, los planos generales y fijos, la descripción de la voz en off, la lucha del Hombre contra la Naturaleza.

\section{Figura 1}

\section{Henry Nielsen muestra la cámara a los niños}

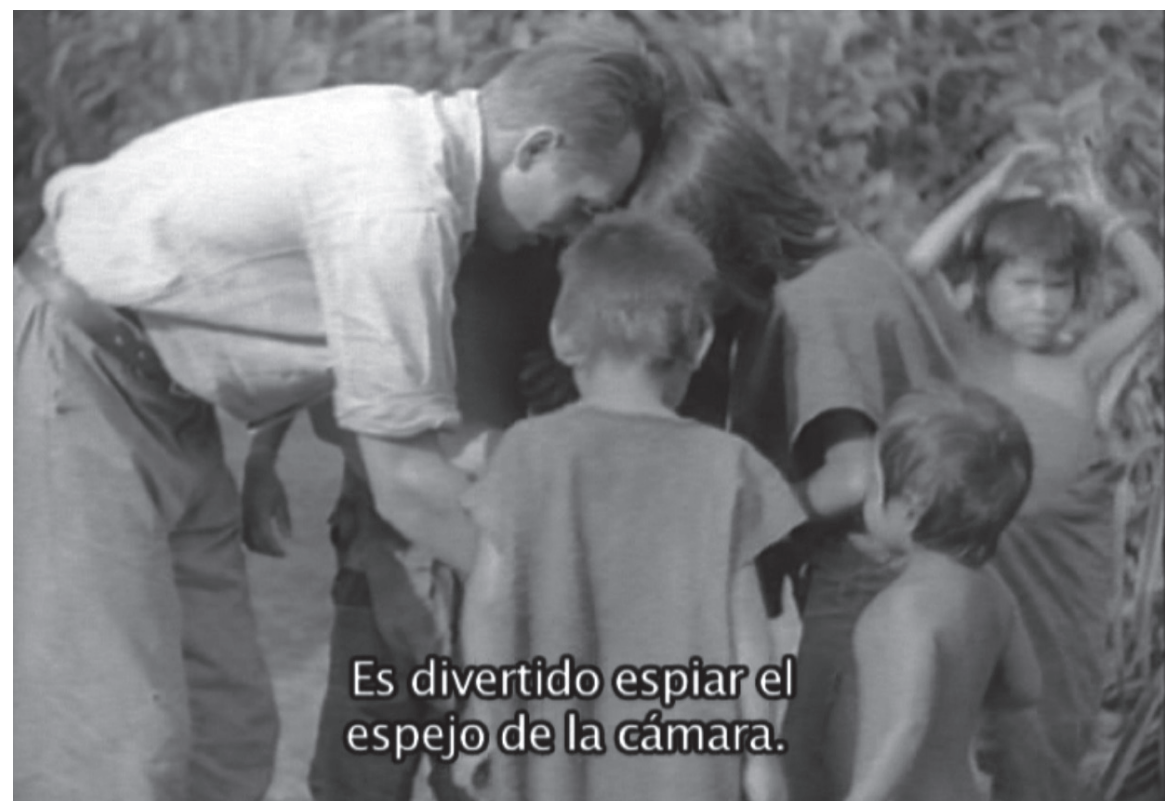

Por el lado de la película "Vikingos...", Blomberg sigue manteniendo como eje formal la construcción de mini-secuencias. Cada una de ellas narra 
diferentes situaciones cotidianas de subsistencia de los colonos en las islas: la cacería, la recolección, la fabricación de azúcar, entre otras. En este sentido, la película se basa en la lucha cotidiana de los colonos nórdicos por subsistir ante un ambiente hostil. A partir del mencionado eje formal, Blomberg segmentó a la película según las actividades, pero también según las familias. Por un lado nos muestra a los Lundberg, por otro a los Stampa y por otro, brevemente esbozado, a los Worm-Muller. De este eje formal se disparan los mismos subejes que sustentan al anterior filme, ellos son: la lucha del Hombre contra la Naturaleza, la utilización de planos generales y fijos, descripción con la voz en off de lo que sucede en la imagen, interactividad, nombres y formas de aprendizaje familiar, narrativa clásica y retrato del modo de vida.

Ambas películas apuntan a retratar el modo de vida de la comunidad desde la observación: los shuar por un lado y los colonos nórdicos por el otro. A partir de filmar situaciones donde la gente del lugar realiza actividades, en su mayoría económicas, Blomberg intenta acercase a la cotidianidad de esas situaciones. Ambos filmes tienen en general características del modo de representación expositivo (Ardèvol, 2006; Nichols, 1997): voz en off del realizador, gran cantidad de planos generales y fijos, autoridad marcada en el realizador, no hay una revelación del dispositivo de filmación y la cámara muchas veces permanece oculta. Sin embargo hay un componente de performatividad (evidencia de la actuación) al hacer posar a los personajes frente a la cámara (ver Figuras 2 y 3 ).

También, ambas películas se corresponden plenamente con el canon de representación del paradigma mimético. Los movimientos de la cámara intentan ser imperceptibles, la altura de la cámara está elevada a la altura del nivel de los ojos, el montaje pretende ser "invisible" y el espacio debe ser continuo y uniforme. La construcción narrativa clásica a partir de la continuidad del montaje, de la estructura (de introducción, problema, y desenlace) y el desarrollo de los personajes, la podemos ver también en ambas películas. Sin embargo lo utilizan de diferentes formas como veremos en las diferencias.

Las dos películas usan el tono lúdico, la vanalización y desproblematización de las situaciones. Esto se da especialmente desde la voz de Blomberg pero también desde la musicalización. Se intenta desde el humor que el espectador establezca una relación de empatía con el "Otro". A la vez, lo lúdico contribuye al ritmo fílmico de la película, liberándola sólo del carácter informativo. Con esto último nos referimos a que no todo es información directa, sino que Blomberg utiliza pequeñas secuencias cómicas para darle "aire" al espectador. 


\section{Figura 2}

Chumbela, líder de la comunidad, toma chicha mientras mira a la cámara. Fotograma extraído de "En Canoa a la Tierra de los Reductores de Cabezas"

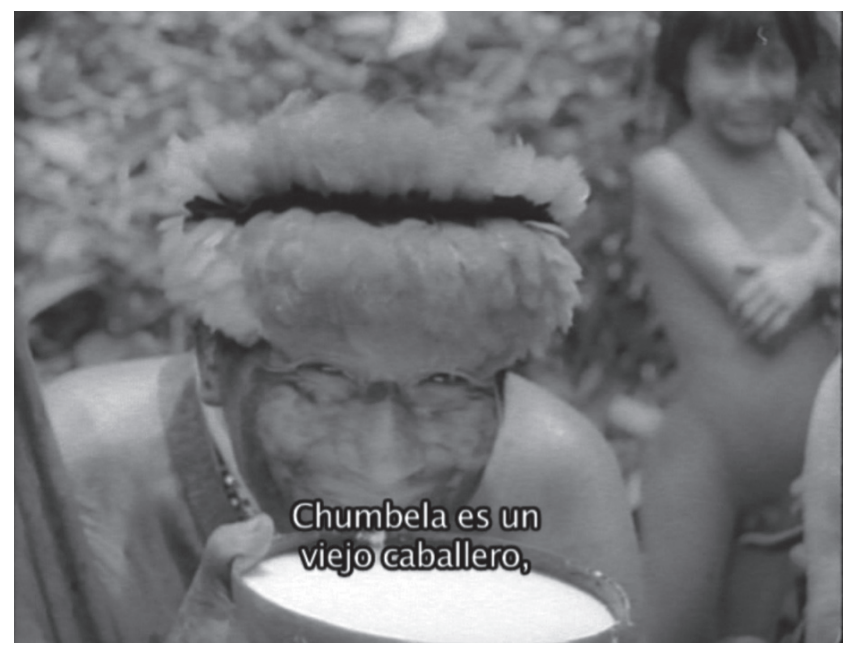

\section{Figura 3}

Arthur Worm-Muller, colono escandinavo, muestra el árbol de papaya mirando a la cámara. Fotograma extraído de "Vikingos en las Islas de la Tortugas Gigantes"

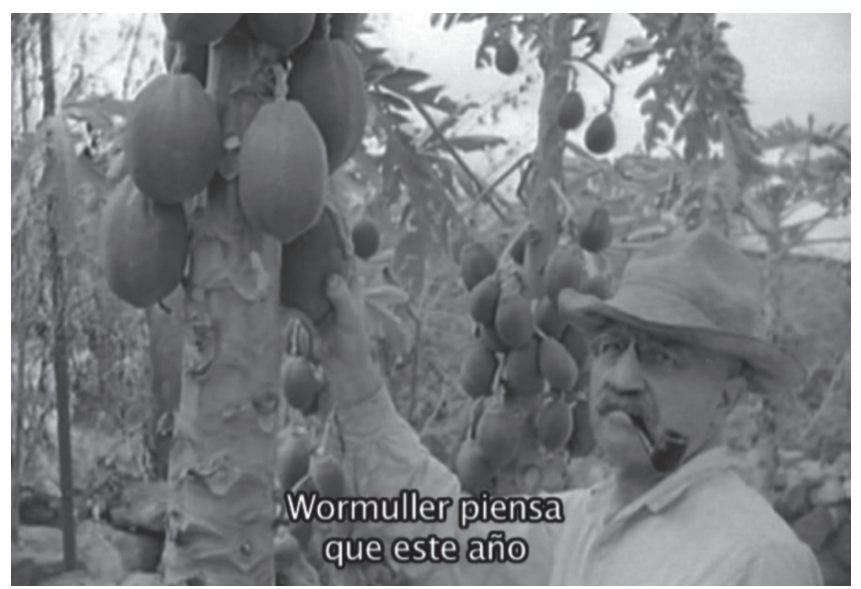


Las diferencias que encontramos entre ambas películas son:

Una de las diferencias que vemos es el punto de vista de la cámara. En "En canoa..." muchas de las situaciones están filmadas con una angulación picada, mientras que en "Vikingos..." la mayoría de los acercamientos Blomberg los hace al nivel de los ojos. Poner la cámara al nivel de los ojos nos da una relación de horizontalidad con el que estamos filmando, ponerla por encima de él, es un signo de autoridad (ver Figuras 4 y 5).

\section{Figura 4 \\ Plano picado. Fotograma extraído de "En Canoa a la Tierra de los Reductores de Cabezas"}

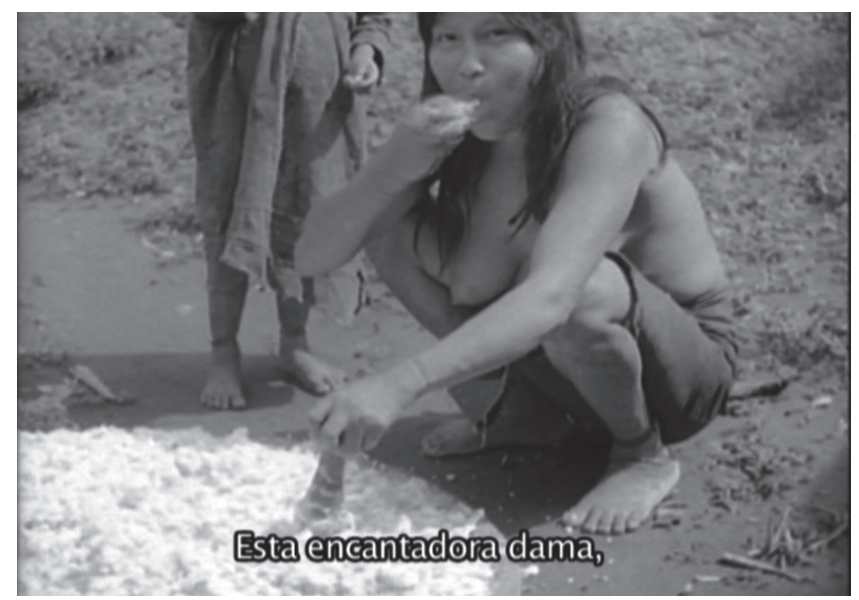

Otra de las cuestiones que aparece en la película "Vikingos..." y en "En canoa..." no, es la enseñanza familiar y las relaciones intergeneracionales. En la primera película, muchas de las actividades que muestra, son realizadas por toda la familia. En la segunda, la mayoría de los personajes están solos. En la primera se destaca lo colectivo, en la segunda lo individual. Sin embargo, a pesar de marcar lo colectivo en "Vikingos...", hay una individualización de los personajes a partir de darles un nombre (ver Figura 3 y Figura 5). Blomberg presenta a los personajes individualmente (Lundberg, Stampa, Worm-Muller, Finssen), mientras que en "En canoa..." solo vemos una masa indistinguida de gente, rasgo típico del modo expositivo de representación. Sólo al que reconoce Blomberg en "En canoa..." es al jefe de la comunidad, llamado Chumbela (ver Figura 2). El resto de las personas no tiene nombre. 


\section{Figura 5 \\ Plano contrapicado. Fotograma extraído de "Vikingos en las Islas de la Tortugas Gigantes"}

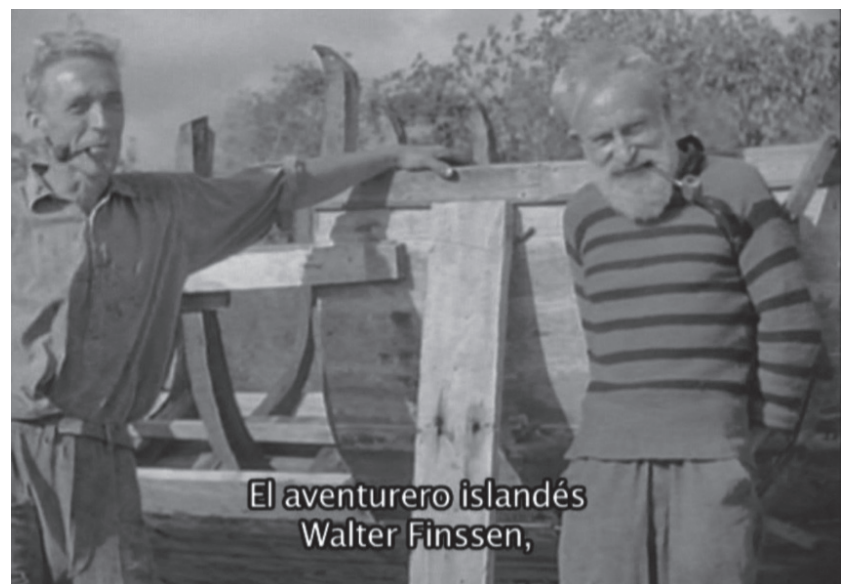

La principal diferencia entre ambas películas se da desde el discurso. En la película filmada en la Amazonia, Blomberg por momentos marca la "cara oculta" que tienen los indígenas, que es su lado salvaje. Si bien en las imágenes se los muestra sonriendo, nos dice desde el discurso que son crueles. La reducción de cabezas, como rasgo exótico de la comunidad, es el núcleo de la película. La ambigüedad (Muratorio, 1994), en la construcción de la imagen de los shuar, es el concepto central que marca las relaciones de alteridad entre los exploradores y los indígenas. Con este concepto, nos referimos a significados que toma la imagen que Blomberg construye, que pueden ser considerados como contradictorios. Por un lado son "salvajes", "violentos" y por lo tanto moralmente malos, mientras que por el otro tienen destrezas técnicas que sólo ellos pueden tener y son alegres. Creemos que el imaginario de los europeos que describe Anne-Christine Taylor se aproxima muy bien a la imagen que construye Blomberg sobre los Shuar, donde afirma que "se caracteriza esencialmente por la conjunción inquietante de un saber técnico (anatomo-farmacéutico) altamente sofisticado y de una primitividad y barbarie moral extremas" (Taylor, 1994, p. 89). Esto se puede ver claramente cuando la voz en off (autoridad exclusiva del narrador) marca un contrapunto con la imagen. Con esto nos referimos a que mientras desde la imagen vemos un primer plano de un shuar sonriendo a cámara, desde la voz en 
off se destaca que son "crueles" (ver Figura 6). Pero además, la ambigüedad no sólo está entre la imagen y el sonido, sino en el tipo de relación que los forasteros establecieron con la comunidad shuar. Por un lado, en el libro "Acampando entre los Reductores de Cabezas" (1938), escrito por el mismo Blomberg para relatar su viaje, el autor afirma que las relaciones eran empáticas y de confianza. Por otro, en la película, podemos ver como constantemente tanto extranjeros como locales, portan armas de fuego, dando cuenta de una situación de inestabilidad y desconfianza. La alteridad, por lo tanto, queda delimitada en este doble juego, entre valores ambiguos y fluctuantes, donde predomina principalmente el exotismo (ver Figura 7).

\section{Figura 6 \\ Presentación de los Shuar. Fotograma extraído de "En Canoa a la Tierra de los Reductores de Cabezas"}

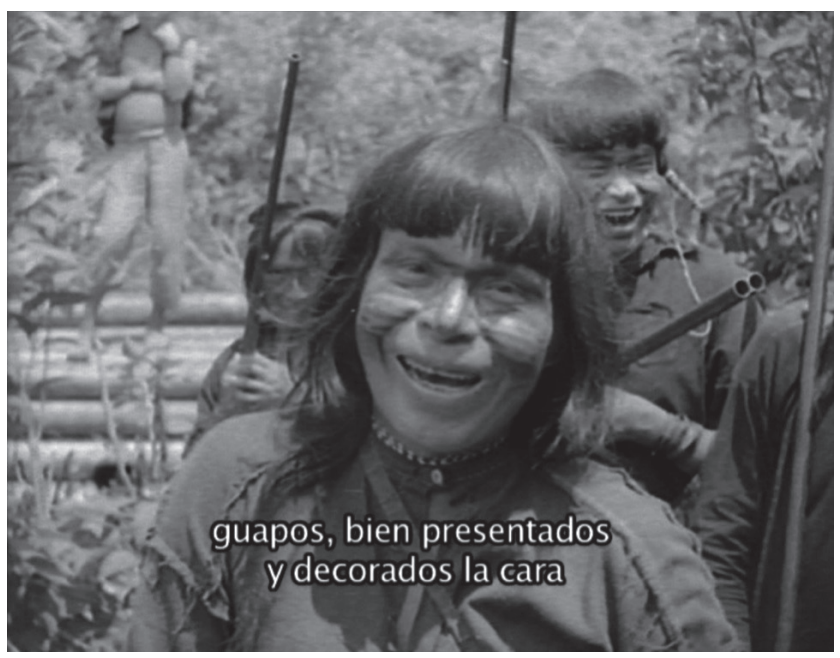

Este es su aspecto: guapos y bien presentados y decorados en la cara y siempre de buen humor. Aunque sonríen a la cámara tienen fama de ser crueles por su espantosa costumbre de cortar la cabeza de las personas. Cogen la cabeza y en un complejo procedimiento la reducen hasta este tamaño. El jíbaro cree que obtiene la fuerza de su enemigo al poseer la cabeza. Y para que no pueda maldecirlo ni murmurar maleficios, le cosen la boca. El que más cabezas ha cortado, tiene el más alto rango social. Pocos blancos han visitado a los reductores de cabezas pero esto no impidió que consiguieran ar- 
mas, camisas y pantalones y otros presentes de la civilización. Pero no siempre han intercambiado estos objetos. Henry nos contó sobre un comerciante quien además de perder sus mercancías también perdió su cabeza (Blomberg 1936, voz en off película "En Canoa a la Tierra de los Cazadores de Cabezas”, Min: 04:24- 05:40).

\section{Figura 7}

\section{Presentación de cabeza reducida fuera de contexto. Fotograma extraído de "En Canoa a la Tierra de los Reductores de Cabezas"}

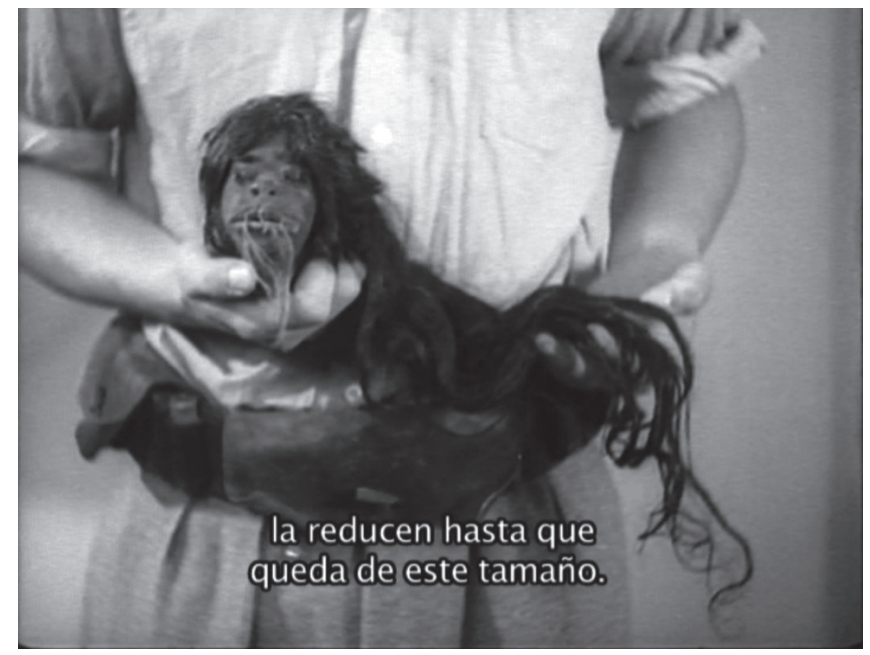

Ahora, si analizamos "Vikingos...", vemos que no hay un doble discurso. Blomberg narra las actividades que realizan los colonos como si él también lo fuese. Si bien nunca utiliza la primera persona para la narración, nos da entender que forma parte de ellos. Lo exótico en esta película es el paisaje y los animales que constituyen un ambiente hostil y salvaje, por lo que los colonos deben desarrollar diferentes estrategias para sobrevivir. A pesar de filmar cacerías de animales, nunca se los nombra como crueles o salvajes a los colonos. En "En canoa..." también se relativizan algunos de los conocimientos, como la construcción de la cerbatana, dándole importancia al conocimiento indígena. Si analizamos esa escena, vemos que fílmicamente se construye de un modo similar a las escenas de "Vikingos...", desde la narrativa clásica. 
La lucha del Hombre contra la Naturaleza lo podemos pensar como un eje en ambas películas. En las dos, se presenta al paisaje como hostil, extraño, exótico, inmenso y deshabitado y es allí donde los grupos locales deben elaborar estrategias para poder sobrevivir. Sin embargo hay una diferencia radical y es que en la película sobre los grupos shuar, se retrata el viaje en canoa hacia el "territorio jíbaro" (como Blomberg lo llama) mientras que en el filme de Galápagos no. Blomberg elige narrar el viaje pero desde un tono dramático (lo mismo se ve reflejado en su libro), dando cuenta de las dificultades y peligrosidades que existía en el recorrido. El desplazamiento espacial de la "civilización" (como Blomberg le llama cuando retornan) a las comunidades indígenas implica atravesar un territorio desconocido y extraño. Sin lugar a dudas que esta idea del espacio amazónico responde a las ideas y los imaginarios de la época, donde el Oriente estaba fuera de la órbita nacional. El paisaje amazónico, inmenso y laberíntico, se remarca desde el discurso pero también desde la elección de los encuadres. Siempre cuando desde la voz en off se habla del paisaje, se eligen planos generales, donde las personas quedan pequeñas en tamaño. Lo dramático del viaje se construye desde lo fílmico, por la utilización de la cámara en movimiento con paneos generales de derecha a izquierda donde personajes se ven pequeños en la inmensidad del paisaje (ver Figura 8). En el relato, Blomberg dice que la canoa "es maniobrada hábilmente por los indígenas, por el río Pastaza, milla tras milla, a través de rápidos y remolinos". Cada vez más alejados de la cámara, se van viendo más pequeños y el paisaje más grande, mientras que la música de tambores y flautas aumenta progresivamente su volumen. La secuencia tiene su clímax cuando la canoa corre peligro, ya que se escapa sola entre los rápidos. Luego del "peligroso" viaje llegan a su objetivo. "Las aguas se hacen más grandes y tranquilas" dice el realizador, mientras que se sigue manteniendo la misma propuesta de cámara: paneos siguiendo la canoa desde planos generales. "Henry ha entrado a la tierra de los jíbaros" dice la voz en off. La imagen se desvanece a un plano negro, la música se corta.

Ahora si analizamos el comienzo de "Vikingos..." la película comienza con un paneo de derecha a izquierda de un plano general de la isla. Dado que el plano tiene una altura aérea, suponemos que fue hecha desde una montaña. El lente que utiliza es un gran angular y esto provoca que las casas se vean pequeñas en un paisaje gigante. Este plano funciona a modo de presentación del paisaje, como extraño, exótico, inmenso y deshabitado. La voz en off, realizada por Blomberg, remarca ese carácter. Allí el realizador 
nos cuenta que vive la colonia escandinava (ver Figura 9). Blomberg ya se encuentra en el lugar al comienzo del filme, no necesita desplazarse fílmicamente. Con respecto a las relaciones de alteridad, hay un Nosotros (escandinavos) que vive en un espacio extraño. El "Nosotros" se construye no sólo por lo que vemos en pantalla, sino por el contexto de circulación en el cual estuvieron las películas. Recordemos que los filmes eran proyectados sólo en Suecia, por lo que los espectadores se veían a "ellos mismos" en la pantalla.

\section{Figura 8}

\section{Presentación del paisaje en la Amazonía} Fotograma extraído de "En Canoa..."

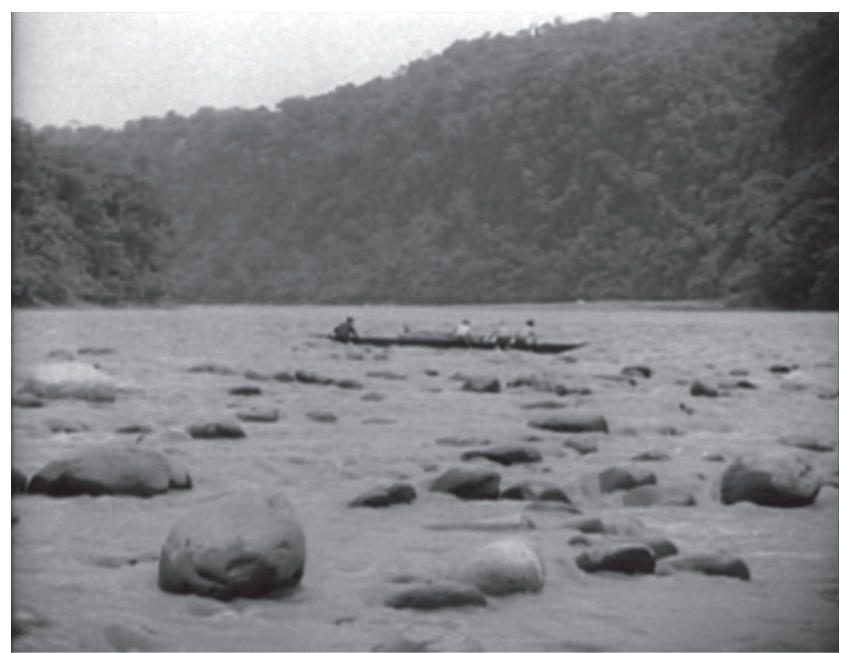

En síntesis, el tiempo y el espacio, características fundamentales del viaje audiovisual, se construyen a partir de la lejanía. Como veíamos, el espacio en ambos filmes se construye como hostil y desolado. Sin embargo el tiempo histórico es diferente. En "En canoa..." la construcción de la lejanía del viaje dramático, hace que también los realizadores se desplacen en el tiempo. Los shuar están ubicados en otro tiempo con respecto a los europeos y ese desplazamiento tiene que ser narrado. Esto se hace notable cuando desde el discurso se marca que "regresan a la civilización". Por el lado de "Vikingos..." el ambiente es lejano y prehistórico, pero los colonos que allí viven no lo son. Blomberg no marca el "retorno a la civilización" en su viaje audiovi- 
sual, simplemente él desde el principio del filme está instalado en la comunidad. Tiempo y espacio se construyen de manera diferente en ambas películas, dando cuenta de la mirada que el realizador tenía con los sujetos filmados.
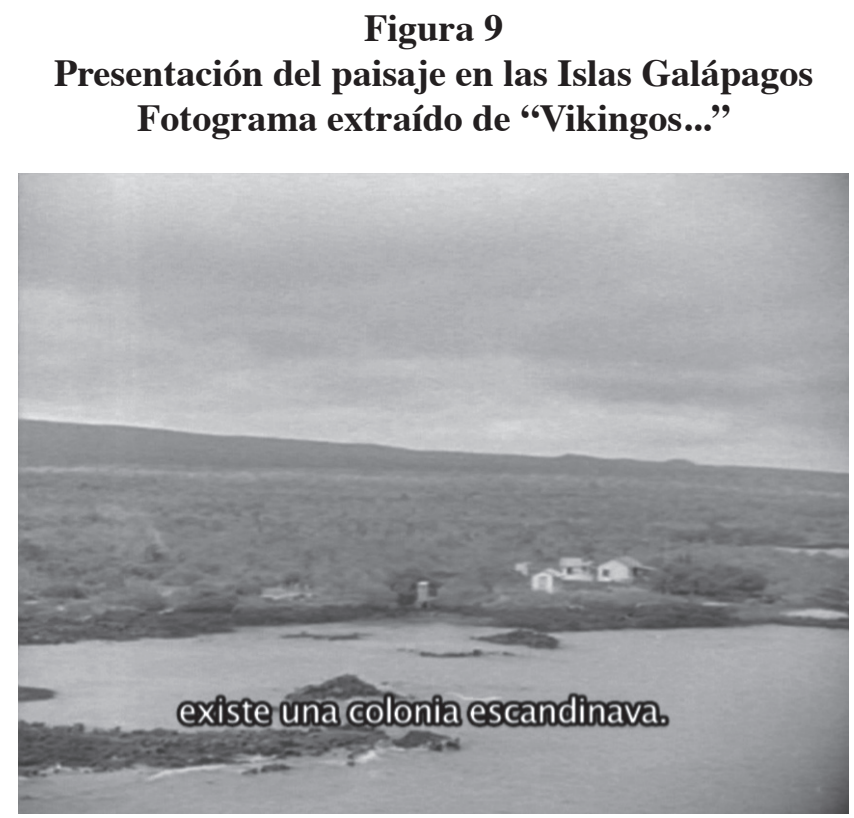

\section{Conclusiones}

Investigar este tipo de imágenes desde los estudios visuales en relación a la Antropología Audiovisual, nos hace pensar en cómo los europeos miran a Ecuador y cómo Ecuador mira a los europeos. Blomberg formó parte de una gama de exploradores- realizadores en todo Sudamérica, pioneros en utilizar la cámara de cine en sus viajes. Es decir, esas primeras imágenes que producían y reproducían, con las ideas traídas de Europa, marcaron un imaginario tanto del territorio insular, como de la sierra, de la costa y de la selva ecuatoriana, que vale la pena seguir investigando. Además, a modo de hipótesis para futuras investigaciones, el trabajo propone que estos mismos imaginarios y formas de representaciones, continúan hasta hoy en día y nos marcan la manera de ver los grupos indígenas y los espacios alejados de las grandes capitales. 
Por último, pretendemos continuar con los estudios sobre la obra de Rolf Blomberg, ya que en el Archivo Blomberg existe gran cantidad de material sobre la misma (películas, fotos, cuadernos, diarios de campo, mapas y cartas, entre otras cosas). Pero no sólo nos debemos detener en Blomberg, sino en toda la gama de exploradores, misioneros, etnógrafos, naturalistas y cientistas, que han realizado imágenes- movimiento de Ecuador. Por lo tanto, se trata de analizar en profundidad, en el cruce entre concepciones antropológicas y visuales, las historias de sus viajes y sus miradas para seguir abriendo nuevos debates en torno a la Antropología Audiovisual ecuatoriana.

\section{Bibliografía}

Ardèvol, E. (2006). La búsqueda de una mirada: antropología visual y cine etnográfico. Barcelona: Editorial UOC.

Aumont, J. \& Michael M. (2006). Diccionario teórico y crítico del cine. Buenos Aires: La Marca.

Blomberg, R. (1936). Hombres diferentes y animales extraños. Caminatas por la Amazonía y Galápagos. Traducido por Marcela Blomberg. Estocolmo: Gebers.

Blomberg, R. (1938). Acampando entre los cazadores de cabezas. Traducido por Marcela Blomberg. Estocolmo: Gebers.

Bordwell, D. \& Thompson, K. (1993). El arte cinematográfico. Barcelona: Paidós. Bordwell, D. (1996). La narración en el cine de ficción. Madrid: Paidós.

Clifford, J. (1999). Dilemas de la cultura: antropología, literatura, y arte en la perspectiva posmoderna. Barcelona: Gedisa.

Cook, P. (1994). The Cinema Book. Reino Unido: British Film Institute.

Giordano M. \& Gustavsson A. (2013). Entre la narrativa de viaje y el discurso antropológico. La primera filmografía en el imaginario del indígena chaqueño. En M. Giordano, L. Sudar Klappenbach y R. Isler Duprat (Ed.), Memoria e imaginario en el nordeste argentino (pp. 23-49). Argentina: Prehistoria.

Griffiths, A. (2002). Wondrous difference: cinema anthropology, \& turn-of the century visual culture. New York: Columbia University Press.

Guarín Martínez, O. (2012). La Amazonía en sus imaginarios cinematográficos: 19141955. Apuntes preliminares. En M. Hering Torres y A. C. Pérez Benavidez (Ed.), Historia Cultural desde Colombia: categorías y debates (pp. 165192). Bogotá: Universidad Nacional de Colombia, Facultad de Ciencias Humanas, Pontificia Universidad Javeriana y Universidad de los Andes. 
Metz, C. (2002). Ensayos sobre la significación en el cine. Barcelona: Ediciones Paidós Ibérica.

Nichols, B. (1997). La representación de la realidad: cuestiones y conceptos sobre el documental. Madrid: Paidós.

Ortega, M. L. (2003). El descubrimiento de América Latina por los documentalistas viajeros. En P. A. Paranaguá (Ed.), Cine documental en América Latina. España: Cátedra.

Rony, F. T. (1996). The third eye: race, cinema, and ethnographic spectacle. Durham: Duke University Press.

Suhr, C. y Willerslev, R. (2012). Can Film Show the Invisible? The Work of Montage in Ethnographic Filmmaking. Current Anthropology, 53(3).

Taylor, A-C. (1994). Una categoría irreductible en el conjunto de las naciones indígenas: los Jívaro en las representaciones occidentales. En B. Muratorio (Ed.), Imágenes e imagineros (pp. 75-106). Quito: FLACSO.

Fecha de recepción: 19/06/2017; fecha de aceptación: 25/07/2017;

fecha de publicación: 01/09/2017 



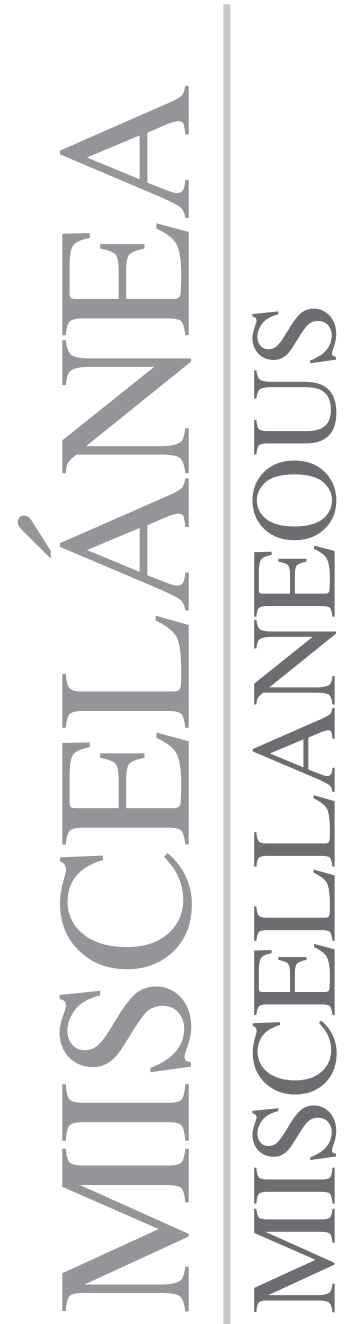





\title{
Tejer y resistir. Etnografías audiovisuales y narrativas textiles
}

\author{
Knit and Resist. Audiovisual ethnographies \\ and textile narratives
}

\author{
Mariana Xochiquétzal Rivera García ${ }^{1}$ \\ marianaxrg@gmail.com
}

\section{Resumen}

El tejido como narrativa ha sido una estrategia muy antigua, utilizada principalmente por mujeres, en donde han plasmado y perpetuado la historia de los pueblos desde su propia visión. Tejer ha tenido objetivos diversos, desde el más evidente que es vestir el cuerpo, hasta cuestiones rituales o políticas. El tejido es un lenguaje que solo puede ser comprendido y transmitido por quien lo experimenta a través del cuerpo.

Este artículo reflexiona sobre el desarrollo de una metodología audiovisual aplicada a una investigación doctoral en torno al tejido y la memoria desde una dimensión etnográfica, política y de resistencia, pero también como un proceso creativo.

Este artículo explora el proceso de realización de cinco videos documentales como un abordaje creativo a los diversos cuestionamientos etnográficos que se fueron suscitando a lo largo de la investigación, y al mismo tiempo, como forma de interacción con las comunidades de tejedoras y negociación de mi presencia en campo.

El trabajo audiovisual, sumado a una exposición itinerante de tejidos y talleres, fue la metodología que permitió ir más allá de la etnografía convencional, para hacer de la investigación, la posibilidad de tender puentes entre grupos de mujeres tejedoras, principalmente entre tejedoras amuzgas en el Estado de Guerrero en México y tejedoras por la memoria en Colombia, pudiendo entrar en diálogo a través de sus relatos tejidos, generando una reflexión potente como mujeres tejedoras y dando un lugar de valor y reconocimiento al trabajo manual que realizan cotidianamente y que ha transformado de manera positiva sus vidas.

\section{Palabras clave}

Etnografía audiovisual, metodología, antropología sensorial, creatividad, narrativas textiles, antropología visual.

Forma sugerida de citar: $\quad$ Rivera García, Mariana Xochiquétzal (2017). Tejer y resistir. Etnografías audiovisuales y narrativas textiles. Universitas, $X V(27)$, pp. 139-160.

1 Doctora en Ciencias Antropológicas. Universidad Autónoma Metropolitana Ciudad de México. Orcid: 0000-0002-2456-1414. 


\begin{abstract}
The knitting as narrative has been a very old strategy, used mainly by women, where they have shaped and perpetuated their stories and the story of their towns through a very unique vision. Weaving had have diverse objectives, from the most obvious that is to dress the body, until ritual or political functions. The weaving is a language that can only be understood and transmitted by those who experience it through the body.

This article reflects on the development of an audiovisual methodology applied to a P.H.D research about the relation between knitting and memory from an ethnographic, political and resistance perspective, but also as a creative process.

This article also explores in the process of filming five documentary videos as a creative approach to the various ethnographic questions that were raised throughout the research, and at the same time, as a way of interacting with the communities of weavers and negotiate my presence in the field. The audiovisual work, in addition to an exhibition of textiles and workshops, were together the methodological route that allowed to build a bridge to connect weavers at different latitudes, mainly among amuzgas weavers in the State of Guerrero, Mexico and weavers of memory in Colombia. Both collectives were able to stablish a symbolic dialogue through their woven stories. Generating a powerful reflection as women, recognizing the value they deserved to their manual and artistic work related to memory. This process has given those women the possibility to transform positively their lives.
\end{abstract}

\title{
Keywords
}

Audiovisual ethnography, methodology, sensory anthropology, creativity, textile narratives, visual anthropology.

\section{Introducción}

Mi acercamiento a los textiles y tejidos, vistos desde sus dimensiones políticas y sociales, comenzó en paralelo al proceso de convertirme en tejedora, admirando los trabajos de otras tejedoras cercanas que se habían iniciado en el oficio a mi lado. 
De manera personal, el tejido me empoderó porque me dio confianza en mí misma, fui capaz de crear y materializar lo que estuviera en mi imaginación.

Este primer acercamiento individual y después colectivo a la actividad del tejido, me brindó las primeras intuiciones que me llevaron a investigar más a fondo prácticas sociales y culturales que estuvieran mediadas por la tejeduría. Fue así que descubrí que el tejido tiene un poder para sanar, cohesionar, unir y organizar grupos humanos, que este oficio en particular tiene características meditativas al ser repetitivo, introspectivo y que ayuda a despejar el pensamiento y aclarar ideas. El tejido cobró en mi vida una dimensión política y transformadora de mi realidad.

En un viaje a Colombia en el 2011 tuve la fortuna de conocer a mi colega Isabel González que en ese momento se encontraba organizando un encuentro de tejedoras por la memoria en la ciudad de Medellín. En ese momento no entendía muy claramente el concepto, pero sabía que se reunirían mujeres de distintas regiones de Colombia que estaban organizadas en grupos denominados costureros, aludiendo al ejercicio de reunirse a tejer y cocer. Estos colectivos o costureros tienen en común el hecho de que sus integrantes son mujeres que han sido 'víctimas' directas del conflicto armado en Colombia. Ellas utilizaron el tejido como una forma de narrar las historias de violencia que como supervivientes del conflicto armado les había tocado vivir: desapariciones, asesinatos y desplazamientos. Encontraron en el oficio del tejido y bordado una forma de comunicar visualmente las escenas que con palabras era difícil o imposible nombrar. Es decir, el tejido como narrativa les permitió ejercer su derecho a la memoria, pero también su derecho a la justicia y reparación.

El tejido entrelaza disciplinas y articula diversos conocimientos, conecta a las personas, es la analogía del tejido social. Tejer es entregarse a otros, es regalar el tiempo de creación a un ser amado, pero también es un medio de subsistencia, resiliencia, resistencia y de empoderamiento. Por estas razones, es posible afirmar que, el tejido hoy en día, se ha vuelto un acto "revolucionario" porque subvierte los principios que lo identificaban al tejido como acto doméstico o como un pasatiempo, sobre todo porque era una actividad que desempeñan principalmente las mujeres.

Cuando volví a México después de esta experiencia y después de haber concluido mis estudios de maestría en antropología visual en la FLACSOEcuador, me motivé a rastrear en mi país experiencias similares donde se involucrara el tejido y el bordado como estrategia colectiva de enunciación y 
narración. Como en aquel momento eran pocas las experiencias al respecto, me di a la tarea de comenzar un proceso de socialización e invitación a tejer para contar historias desde una perspectiva principalmente femenina.

Elegí implementar la experiencia del tejido con fines narrativos y regenerativos del tejido social en una cooperativa de mujeres tejedoras en la comunidad amuzga de Xochistlahuaca o Suljaa' en lengua amuzga y que se ubica en la región Costa Chica en el Estado de Guerrero.

Elegí esta zona porque es una región que se destaca por sus textiles tradicionales y porque alberga a mujeres tejedoras de telar de cintura, cuya tradición textil data de la época prehispánica. Me interesaba adentrarme en una práctica de origen indígena que pudiera contrastar con la práctica adquirida por las mujeres colombianas en medio de la guerra.

Algunas de las preguntas iniciales en torno al ámbito comunitario en la actividad textil fueron formuladas de la siguiente manera: $¿$ Tejer en colectivo genera redes de solidaridad, procesos de empoderamiento y autonomía? ¿Tejer de esta manera puede considerarse una forma de resistencia? ¿Pueden considerarse los textiles como textos? ¿El tejido constituye una narrativa? ¿El telar de cintura y el tejido en general son formas de albergar la memoria? ¿De qué forma las metodologías audiovisuales pueden ayudar a comprender el fenómeno textil? Este artículo se enfocará en responder a esta última pregunta a partir de la experiencia metodológica desarrollada.

Hacer una conexión entre las tejedoras por la memoria en Colombia, que tejen como militancia, y las tejedoras en México que tejen, además de como legado cultural, como forma de resistencia para hacer frente a sus circunstancias sociales y económicas, me pareció un ejercicio comparativo fundamental que me permitió analizar diversas aristas en torno al tejido como metáfora y materialidad de la memoria. Ambos ejemplos me permitieron hablar del tejido en su dimensión política -tanto en lo privado como en lo público-, pero también desde las particularidades de cada tejedora ubicada en una realidad social particular.

¿Cómo lograr metodológicamente un encuentro sensible y cercano con las tejedoras? ¿Cómo poder hablar de los conflictos que enfrentan las tejedoras amuzgas en sus contextos? Además de la etnografía que llevé a cabo durante el trabajo de campo, me dispuse a diseñar una serie de talleres que acompañarían una exposición que viajó de Colombia a México para socializar los trabajos tejidos de uno de los costureros colombianos. El taller para las tejedoras amuzgas consistió en la elaboración de muñecas de trapo, con la finalidad de que cada una de ellas pudiera contar su historia personal -a 
manera de autorepresentación o autobiografía-, o bien la historia de alguna mujer relevante en su vida.

La historia de vida es un instrumento indispensable para llegar a la subjetividad y para encontrar sus relaciones con el mundo objetivo de lo social. Es devolver al individuo su lugar en la historia (De Garay, 2013, p. 26).

Otra parte metodológica fundamental que acompañó la investigación y que es el objetivo analizar en este artículo, es la utilización de medios audiovisuales, los cuales me permitieron un acercamiento profundo con las mujeres tejedoras y una complicidad necesaria para su representación en imágenes.

Los medios audiovisuales en antropología despiertan pasiones y desconfianzas. La utilización generalizada de estas técnicas queda aún lejos en nuestra disciplina y muchos las consideran todavía como inapropiadas para la exposición teórica o simplemente como herramientas auxiliares, más que como un nuevo campo de investigación y experimentación (Ardèvol, 1994, p. 13).

Me propuse intentar que las imágenes producidas fueran siempre encausadas para el beneficio de la organización. Que mi mirada que las encuadraba y retrataba constantemente estuvieran en la medida posible pensada en satisfacer sus demandas, que en ese momento era la difusión de su trabajo.

"La cámara es un instrumento creador de realidades, en lugar de simplemente un artilugio para descubrir la realidad" (Grimshaw, 2008, citado en Vila et al., 2008). Con esta afirmación sostengo la idea de que los medios audiovisuales pueden no solamente construir realidades, aunado a la posibilidad de informar, transmitir y mostrar, sino que es una vía para evidenciar y mitigar las relaciones de poder que inevitablemente surgen durante el trabajo de campo. Por otro lado, los medios audiovisuales logran de manera más clara incluir a los participantes en un proceso comunicativo "contribuyendo a la creación del contexto de la investigación”" (Ardèvol, 2006, p. 243).

Tanto los talleres prácticos de tejido, como los medios audiovisuales, me permitieron acercarme de forma horizontal con mis colaboradores en campo y pude ampliar la lente observadora a una participativa que intervino en la realidad compartida. 


\section{La urdimbre audiovisual: El tejido de las imágenes}

A lo largo de la investigación, llevé a cabo lo que yo he decido llamar etnografías audiovisuales. Resulta complejo categorizar el tipo de trabajo audiovisual que realicé porque cada uno apeló a procesos distintos de construcción narrativa y tuvieron finalidades distintas. Desde un documental reflexivo sobre mi historia personal como tejedora; un documental sensorial basado en la experimentación con los sonidos del telar, hasta narrativas más lineales y descriptivas como ocurrió con el proceso de los talleres y el intercambio de conocimientos con la exposición.

Elisenda Ardèvol (1994) hace una interesante reflexión con respecto a la categoría de cine etnográfico, visto por un lado como metodología de investigación-acción-participación (etnografía visual), y el cine etnográfico como documental con orientación antropológica, este último puede o no ser grabado por un antropólogo. Dentro de esta distinción cabrían consideraciones de orden ético que se deben considerar como lo es la forma en que se representa una temática y las relaciones que se establece con las personas y las imágenes producidas sobre ellas.

Esta perspectiva me lleva a definir mi trabajo dentro de ambas vertientes, en principio porque las cinco etnografías audiovisuales que realicé hicieron parte del proceso de investigación y sirvieron metodológicamente para resolver inquietudes etnográficas, pero al mismo tiempo tienen un lenguaje cinematográfico propio que lo hacer comprensible como un texto independiente a la escritura.

A esta discusión, el sociólogo Mario Ortega añade:

Como todo antropólogo visual es portador de una óptica cultural sobre el grupo que va a estudiar, su subjetividad siempre está presente en la investigación. El asunto es saber asumir esa subjetividad para que se muestre, buscando explicar el hecho sin distorsión o ideología particular. El investigador debe ir más allá de sus intereses académicos para identificar las necesidades y demandas del grupo con el que se trabaja (2009, p. 178).

Esto es fundamental pues remite a la necesidad de evidenciar a través del trabajo audiovisual, las relaciones de poder que inevitablemente se presentan durante el trabajo de campo, lo que implica asumir la subjetividad de nuestra mirada e intentar conjugar dicha subjetividad con la de los participantes, buscando generar relaciones más horizontales donde se estimule por 
un lado, el diálogo intercultural que se propicia a partir de la creación de una obra audiovisual, y por el otro, se ponga el conocimiento al servicio de las necesidades de las comunidades participantes.

A partir de estas reflexiones, definimos para este artículo a la etnografía audiovisual como el entramado narrativo que se establece en la elección y estructuración de imágenes, sonidos y textos para expresar la intersubjetividad con respecto a la historia que se decide contar. Esta elección debe estar justificada por la relación establecida entre el realizador y los participantes o colaboradores con el fin de representar y comunicar de manera sensible y emotiva el tema en cuestión, al tiempo que sirva para explorar sobre problemáticas y preguntas de investigación antropológica.

A continuación, se presentan las etnografías audiovisuales realizadas en orden cronológico porque gradualmente la narrativa y la estética fueron cobrando mayor fuerza a medida que mi experiencia utilizando la cámara y la confianza con las tejedoras iba en aumento. Por esta razón, será fundamental visualizar cada uno de ellos para comprender cabalmente la sustancia narrativa, textual y audiovisual que sustenta cada etapa de la investigación.

Para facilitar el acceso a cada video, he creado un código QR para llegar de manera sencilla a cada uno. Si usted lector quiere acceder más rápido a cada enlace, sólo necesita descargar un lector QR en su teléfono celular y escanear el código desde su pantalla para que automáticamente lo lleve a la página web donde sólo tendrá que reproducirlo. En caso que no cuente con un teléfono "inteligente", puede copiar en su navegador la liga que aparece como segunda opción de visualización.

He decidido llamar urdimbre audiovisual a este proceso reflexivo y etnográfico que conlleva el trabajo documental. La palabra urdimbre audiovisual, alude a la metáfora que envuelve a la urdimbre como base o cimiento sobre el cual se teje, es decir, la plataforma necesaria sobre la cual emerge la creatividad. Sin una buena base de urdimbre, el tejido no podrá desarrollarse de una manera correcta, por eso es fundamental que la base esté firme desde su inicio en el proceso de urdido y montaje de urdimbre para lograr un bello y útil tejido.

Algo similar ocurre con el tejido de las imágenes, la urdimbre equivale al vínculo afectivo con lo que se filma, la trama es la historia, y los hilos son todas las variantes posibles en la que las imágenes pueden combinarse para generar sentido.

Antes de hablar sobre cada experiencia audiovisual y su relación particular con la investigación, preciso tomar como punto de partida la definición 
que hace el antropólogo visual Antonio Zirión para referirse al cine como experiencia estética y cognitiva, así como establecer el papel que tiene la cámara dentro de la investigación antropológica:

Consideramos que el cine es, primordialmente, una forma de experiencia humana, un fenómeno estético y cognitivo más allá de un lenguaje, una tecnología, una disciplina artística o una industria. Podemos afirmar que hay cine cuando se da una interacción entre determinada secuencia de imágenes y un sujeto dispuesto a navegar a través de ellas. Por otro lado, más que únicamente imágenes que se mueven, el cine se trata de imágenes que nos mueven, nos conmueven, nos hacen pensar y sentir, y a veces también nos impulsan a actuar (Zirión, 2015, p. 53).

Me identifico con esta definición porque en mi experiencia audiovisual pude discernir entre la capacidad epistemológica, expresiva y sensible que tiene la composición visual y sonora, en contraposición con el mero registro visual que sólo aporta cierto tipo de información, pero que no genera un sentido propio o colectivo, ni conmueve. Este es el reto que le toca a los antropólogos visuales sortear para demostrar que la narrativa de historias en clave antropológica o desde una perspectiva etnográfica no está peleada con las formas estéticas y puede adherirse a un lenguaje cinematográfico que permita transmitir experiencias, sentimientos, emociones y puntos de vista. Estos procesos deben evidenciar la proximidad con las personas, la complicidad y el compromiso con quien se colabora.

El cine puede ser una importante herramienta de transformación social, de divulgación, de reflexión. Tiene la capacidad de producir atmósferas que lleven a los espectadores a sentir aspectos de una cultura y envolverse sensiblemente con las historias o de identificarse y empatizar con los personajes.

La ampliación del campo de acción de la antropología a partir de la experimentación con el cine, ha logrado borrar los límites entre ficción y realidad, entre la imaginación y el conocimiento científico. Posicionar al antropólogo como narrador y como co-creador me parece fundamental para la vinculación de la disciplina con conceptos fundamentales como la experimentación, la reflexividad, la creatividad, el arte, la imaginación y el conocimiento colectivo (Rappaport, 2007).

Cada uno de los videos que pude realizar, considero que tienen una carga emotiva personal que habla en general de las apuestas del oficio de la tejedora en ámbitos que van más allá de lo económico, como lo es la trans- 
misión de saberes, para lo cual me enfoqué en transmitir al espectador la dimensión sonora, afectiva, narrativa y sanadora que tiene el tejido. A lo largo del trabajo de campo, la cámara ha sido un medio que me ha permitido retratar a las mujeres tejedoras y construir narrativas personales sobre lo que ellas me comparten respecto a su quehacer.

En términos etnográficos, pensamos la cámara no sólo como una herramienta de registro, sino como un dispositivo que permite acceder y conocer de manera creativa determinada realidad, incitando el diálogo intercultural y permitiendo a los sujetos expresarse, reconocerse y generar conocimiento compartido.

He intentado tejer en mi trabajo documental relaciones honestas, transparentes y horizontales, privilegiando la emotividad y la reflexividad etnográfica. Cada una de las experiencias que voy a narrar, fueron pauta para establecer confianza, negociar mi presencia en campo, colaborar con las mujeres tejedoras, difundir esta temática y hacerlas partícipes del proceso de creación, así como visionar el material con ellas para que aprobaran previamente la pertinencia del discurso construido.

Las etnografías audiovisuales son una invitación a sumergirse en la poesía que se encuentra en las metáforas del tejido y que como tejedora y realizadora audiovisual busqué plasmar sobre la base de mi entendimiento, sentimientos y vivencias individuales y colectivas que tuve a lo largo de la investigación.

Tejer para no olvidar (2012) 8 minutos

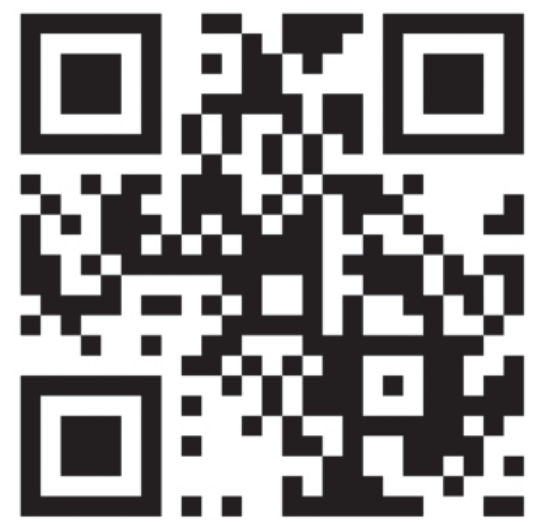

https://vimeo.com/58517165 
Con una postura sensible y creativa frente al proceso etnográfico, he encaminado mi experiencia antropológica como la posibilidad de aprender de otros, pero también como la posibilidad de aprender sobre mí misma. La creación audiovisual me ha permitido establecer puentes entre la creatividad y lo invisible (los afectos y las emociones), con la producción de conocimiento antropológico sobre bases teóricas y metodológicas. En este sentido, el cine conjuga en mí, la pasión de tejer con hilos, tejer con imágenes, tejer con palabras, pero sobre todo tejer comunidad.

Cuando comencé con esta investigación sabía que me enfrentaría a las dificultades que significa intimidar en ciertos espacios y con ciertas mujeres que no comparten la misma lengua, ni la misma historia de vida. Los temas que me interesaban tocar no eran sencillos de nombrar ni de compartir, sabía que la investigación exigía de las personas involucradas cierto nivel de confianza y cercanía para que se atrevieran a crear a mi lado. Por esta razón, decidí en primera instancia realizar un trabajo audiovisual personal y altamente reflexivo, por lo que me propuse contar mi historia como mujer, como antropóloga visual y como tejedora. Realicé un primer video donde sería yo quien se expondría ante el otro de una manera honesta, sencilla y que hablara de mi quehacer, mi sensibilidad y mi forma de ver el mundo, aunado a esto, el video expone también los principios y objetivos de mi investigación, fungió al mismo tiempo como una invitación para incentivar a las mujeres con quienes me disponía a realizar trabajo de campo para abrirnos conjuntamente en un diálogo horizontal e íntimo.

Tejer para no olvidar es una foto narrativa. Con ayuda de música, sonidos y voz en off logré una composición que narra cómo me inicié en el tejido, bajo qué contexto y situación de mi vida, mi transitar por este quehacer, desde la relación con mi abuela hasta la creación de un colectivo de tejedoras con mis compañeras de universidad, después hablo del tejido en contextos de guerra y finalmente lanzo una invitación para tejer historias de manera colectiva.

El objetivo de este primer video era compartir de una manera clara y sencilla el porqué de mi investigación, por lo que me sirvió como una carta de presentación para poder negociar mi presencia en campo. 
Escribiendo sobre el telar (2013) 12 minutos

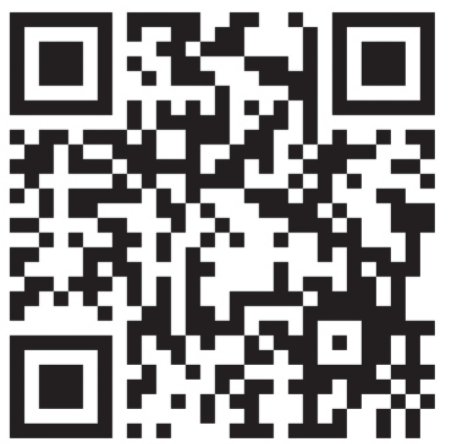

https://vimeo.com/109621801

El video y la fotografía son soportes que tienen como característica principal, la capacidad para resguardar y de alguna manera perpetuar el instante, la memoria en forma de imagen.

Si bien este documental se enmarca en la experiencia del taller de telar de cintura que imparten de manera gratuita las tejedoras de la cooperativa La Flor de Xochistlahuaca para las niñas de la comunidad, se refleja también cómo se lleva a cabo la transmisión de conocimientos alrededor del tejido y se puede ver el tipo de información que está resguardada en la técnica de telar de cintura. Así mismo se comprende la importancia que tiene aprender este oficio para las mujeres amuzgas y la relevancia que tiene dentro del marco identitario que define la cultura amuzga.

Esta fue la primera experiencia audiovisual que realicé para las tejedoras amuzgas en el 2013. A sugerencia de las maestras tejedoras se tituló Escribiendo sobre el telar, recreando la metáfora que refiere a la acción de tejer como sinónimo de escribir.

Tuve la oportunidad de registrar durante tres semanas y a petición de ellas, el proceso de enseñanza-aprendizaje que se transmite a las niñas de entre 5 y 8 años.

Fue una oportunidad única y genuina de comenzar a adentrarme en la pedagogía del telar de cintura, pues yo, que me asumía en esos momentos como una niña, aprendí a la par de ellas -aunque a través del ejercicio documental- las cuestiones más elementales que constituyen el conocimiento 
del telar. Pude incluso aprender unas pocas palabras en ñomndaa y entender por qué es tan importante para ellas mantener viva esta tradición y los significados que se tejen sobre la urdimbre del telar.

Fue la oportunidad también de documentar a doña Florentina López de Jesús, fundadora de la cooperativa. A los pocos meses de haber terminado el documental ella falleció inesperadamente, lo cual convirtió a este documental en el último registro donde ella aparece, y para las tejedoras, la memoria de su imagen resguardada para la posteridad es de gran valor.

\section{Telares sonoros (2014) 3:12 minutos}

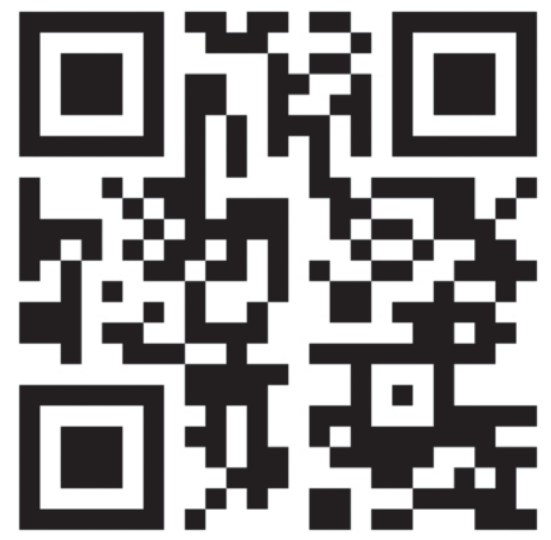

https://vimeo.com/98899180

Telares sonoros implicó un proceso creativo y colaborativo que nació de la experiencia personal al aprender a tejer en telar de cintura. El aprendizaje experimentado en mi cuerpo, me permitió comprender el lenguaje que habita en los hilos. Esta reflexión dio lugar a la discusión teórica que se ha venido desarrollando en los marcos de la antropología visual, que es la cuestión sensorial. Para este fin, decidí explorar la dimensión sonora que se desprende del proceso de tejer en telar de cintura a través de un ejercicio audiovisual que se convirtió en metodología para dialogar con las tejedoras sobre aspectos "invisibles" que enmarcan su oficio: las emociones, las concepciones sobre el telar como un ser vivo y la relación con lo femenino. 
La antropología sensorial estudia los sentidos como elementos que forman, estructuran y significan los conocimientos al ser ordenados y regulados socialmente. Entre algunos de sus exponentes se encuentra David Howes y Sarah Pink. D. Howes plantea que el antropólogo no debe interpretar las culturas, sino sentir las culturas. En su libro The Empire of the Senses. The Sensual Culture Reader (2005), reflexiona sobre el acto revolucionario que implica para la disciplina antropológica reubicar su prioridad teórica -que se determinaba por el lenguaje y los símbolos- para ampliar sus horizontes al plano sensorial, a la experiencia que se encarna en el cuerpo. Por otro lado, Sarah Pink en Doing Sensory Ethnography (2009), comenta que la etnografía sensorial es el proceso en el que el antropólogo se pregunta cómo la sinestesia (que quiere decir que los sentidos están interconectados e interrelacionados) se integra tanto en la vida de las personas con las que se participa, así como el etnógrafo utiliza sus sentidos para desempeñar su trabajo. Plantea entonces la posibilidad de convertir la sensorialidad en una estrategia metodológica que tenga un compromiso teórico para abordar temas como la memoria y la imaginación. Esta metodología se preocupa por el papel que tiene la subjetividad y la experiencia dentro de la etnografía, y siendo este aspecto especialmente subjetivo, lo sensorial tiene que enfrentarse a la creatividad del etnógrafo para descifrar formas de acercamiento apelando al sentir. No existe un manual para realizar etnografías sensoriales, sino que son procesos que se construyen con base en el desciframiento de los códigos y sistemas de sentido y de sentir.

Al ser complicado teorizar a partir de la subjetividad, es necesario llevar a cabo acciones de colaboración en conjunto con las sociedades con las que se trabaja, con el fin de encontrar acertadamente las maneras de develar cómo dichos sistemas culturales construyen y significan la identidad de cada cultura.

De acuerdo a los aportes de esta corriente, decidí que la etnografía audiovisual correspondiente a este aporte teórico, podría servir para que las tejedoras pudieran interpelar mis inquietudes con respecto a la concepción simbólica del telar. El video, combina elementos estéticos, musicales y poéticos para visibilizar el complejo proceso del tejido en telar de cintura, y transmitir a partir del sonido que se desprende de este proceso, una experiencia corpórea que no es muy tomada en cuenta por los estudios sobre textiles, lo que yo llamo, la sonoridad del saber-hacer en telar de cintura.

La idea de extraer los sonidos involucrado en el proceso textil nació de dos experiencias concretas, una experimentada por mi cuerpo al estar 
aprendiendo a tejer, y la otra a partir de un relato sonoro. La primera ocurrió mientras tomaba el taller de telar de cintura y como resultado de pasar horas observando a las mujeres y niñas tejer. Llamaron mi atención los sonidos rítmicos que se desprendían al mover cada instrumento al tejer.

Interpretar y dar significado a los sonidos en la práctica textil para este caso, me brindó información relevante sobre el conocimiento de esta técnica, su especificidad y por supuesto las concepciones simbólicas ligadas a este quehacer.

Para mostrar lo anterior, comparto la reflexión de la tejedora Fortunata Antonio que surgió posteriormente de haber visualizado colectivamente la pieza audiovisual:

El telar es como si fuera música, lo vas acomodando hace ruido como si fuera una música. Luego los palos tienen sonido diferente, y cuando le das con el hueso, es otro sonido y ya pues el palo tiene su sonido, es como si estuvieras platicando con él o haciendo música. El telar es como si fuera familia, no lo puedes abandonar, es como si fuera un hijo, hay que estar pendiente de él, no maltratarlo, cuidarlo (Entrevista, junio 2015).

Por otro lado, el relato sonoro que incentivó este video fue la descripción de una tejedora de 79 años. Ella cuenta que cuando era pequeña, recuerda que muy temprano por las mañanas se escuchaba al unísono el sonido que producían las mujeres del pueblo desde sus hogares al golpear con los palos de otate el algodón para aplanarlo antes de ser hilado. Esta actividad tenía que realizarse muy temprano, antes de que el viento soplara muy fuerte y el algodón se volara, es por eso que las voces de los palos -figurando el sonido de muchos tambores-, se sincronizaban por las mañanas, haciendo de este sonido un referente acústico de la comunidad.

Para realizar la construcción sonora fue necesario reconocer las limitaciones que a veces tenemos los antropólogos para realizar ciertas tareas de orden técnico, o bien requerimos conocimientos complementarios para lograr nuestros objetivos. Para poder consolidar esta pieza, colaboré conjuntamente con Josué Vergara, músico y diseñador sonoro con quien compartí esta idea para que él colaborara planteando una estructura musical sobre la cual se irían anexando los diversos sonidos del telar.

Para construir la narrativa sonora, partimos del orden del proceso textil, es decir, los pasos que se llevan a cabo para confeccionar una prenda. ¿A qué suena el urdido, el aplanado, el hilado y el tejido? ¿Qué habilidades y conoci- 
mientos se requieren para llevar a cabo cada una de ellas? Grabamos variedad de sonidos con distintos micrófonos en diversas posiciones y perspectivas.

Posteriormente, nos inquietó la cuestión musical de la comunidad, por lo que buscamos a músicos tradicionales, para este caso, el señor Feliciano Guadalupe, músico de violín, nos permitió que grabáramos distintos sones tradicionales.

Integramos a la pieza un poema titulado Quisiera ser algodón, escrito por Héctor Onofre, un poeta de la comunidad. Le pedimos a una tejedora que nos ayudara a traducirlo en ñomndaa y ella lo grabó en ambas lenguas.

La base rítmica sobre la que se construyó el diseño sonoro fue el son de violín, sobre ese tiempo rítmico se fueron insertado los sonidos, respetando el orden real del proceso textil: aplanado, hilado, urdido y tejido.

La finalidad de este experimento etnográfico fue saber qué despertaba en ellas la percepción de sus propios sonidos en la práctica textil, y me sorprendió que tiempo después, leyendo el libro El artesano de Richard Sennett, encontré la siguiente cita que expresa una percepción similar a la mía:

Repetir una y otra vez una acción es estimulante cuando se organiza mirando hacia delante. Lo sustancial de la rutina puede cambiar, metamorfosearse, mejorar, pero la compensación emocional reside en la experiencia personal de repetir. Esta experiencia no tiene nada de extraño, todos la conocemos: es el ritmo. Ya presente en las contracciones del corazón humano, el artesano ha extendido el ritmo a la mano y el ojo (Sennett, 2009, p. 217).

Ese ritmo del que habla Sennett y que descubrí en las tejedoras, me permitió elaborar esta pieza audiovisual que al mismo tiempo sirvió metodológicamente para que una vez que ellas vieran el resultado, pudieran hacer una reflexión sobre su percepción.

Con esta experiencia etnográfica de corte experimental, lo que procuré fue alertar a las tejedoras sobre la riqueza no sólo visual de las prendas que ellas elaboran, sino del ritmo que sus cuerpos producen de manera integrada y que sin duda repercute en la forma en que aprenden este conocimiento, siendo el ritmo una demostración del dominio de una compleja técnica textil. Comprender los textiles desde su dimensión sensorial me ha permitido acercarme al conocimiento corpóreo de las tejedoras, al mundo de lo aparentemente invisible. 


\section{Re- tejiendo nuestro taller (2016) 3 minutos}

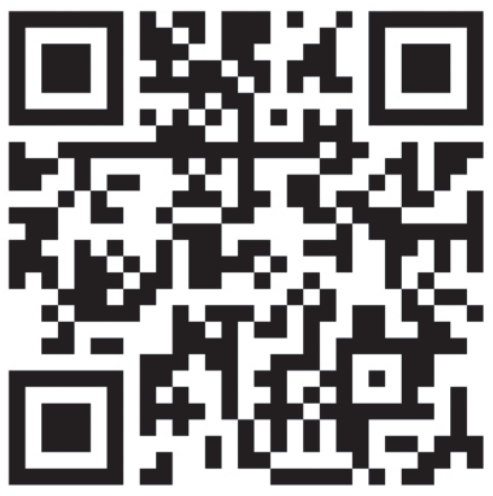

https://vimeo.com/158946012

La cooperativa La Flor de Xochistlahuaca tiene una alianza con dos diseñadoras, quienes a través del financiamiento de una fundación estadounidense comenzaron a trabajar junto a la cooperativa para mejorar la línea de producción. Esta ha sido una estrategia exitosa de trabajo colectivo del que la cooperativa se ha visto favorecida.

Como una de las actividades que realizaron las diseñadoras con la cooperativa, fue preguntarles a las tejedoras qué creían que hacía falta a su organización. La mayoría de ellas coincidió que hacía falta remodelar el espacio de trabajo. Para lograrlo, impulsaron el proyecto de lanzar una campaña de fondeo por Internet. Esta es una estrategia que actualmente ha sido muy recurrente por organizaciones y artistas que tienen proyectos en desarrollo, pero que no cuentan con el financiamiento para llevarlo a cabo, así que existen plataformas por Internet especializadas en ello. El video que se presenta durante la campana es fundamental para el fondeo porque es donde se sintetiza el proyecto y debe alentar a las personas a hacer sus donaciones.

Después de cuatro años de trabajo de campo, las tejedoras me solicitaron que yo realizara dicho video, el cual fue financiado por ellas, es decir, cubrieron los gastos de transportación, alimentación y hospedaje del equipo de producción.

Esta situación se tornó interesante porque fue una prueba de la confianza consolidada a lo largo del trabajo de campo, lo que permitió invertir el 
esquema clásico de investigación, tornándose en un proceso colaborativo y una suerte de antropología compartida en donde se plantean nuevos retos, escenarios y desafíos.

De acuerdo con J. Rappaport (2007) y George Marcus (2001), la etnografía colaborativa es el proceso de integración a la investigación de las personas que poseen los conocimientos locales para crear conocimiento colectivo, de esta manera las personas dejan de ser concebidas como proveedoras de información para hacerlas partícipes, co-autores y colaboradores de la investigación. Este planteamiento tiene como fundamento intentar mitigar las relaciones de poder que se instauran entre los investigadores-antropólogos y los sujetos de estudio. Cada vez con mayor frecuencia en antropología se recurre a esta tendencia debido a la importancia que tiene la comunidad en la participación activa durante el proceso de construcción de conocimiento y que casi al final de esta investigación se pudo poner en práctica con esta importante petición de ellas hacia mí y que se puso en escena durante el rodaje al decidir colaborativamente el guion y estructura del audiovisual.

Durante la grabación del video me hospedé como de costumbre en casa de la tejedora Divina de Jesús, sobrina de Florentina, la fundadora de la cooperativa y que falleció en el 2014. Uno de los días de grabación, Divina me comentó que había tenido un sueño muy revelador y significativo porque había soñado a su tía Florentina. El contenido del sueño me sorprendió:

Soñé que Yecenia (su hija) iba caminando por la calle con mi tía Florentina, entonces yo veía que entraban a una oficina y de ahí salía Florentina con una cámara de video enorme en las manos, y le decía a Yesi que con esa cámara comenzarían un nuevo proyecto para la cooperativa.

El sueño según la interpretación de Divina, simboliza la aprobación de Florentina para la realización del video y la remodelación del espacio. El sueño refleja la importancia que tenía el video y la cámara como herramienta para la transformación de su espacio de trabajo y el nuevo rumbo que tomarían las tejedoras en el escenario textil. 
El hilo de la memoria (2015) 20 minutos

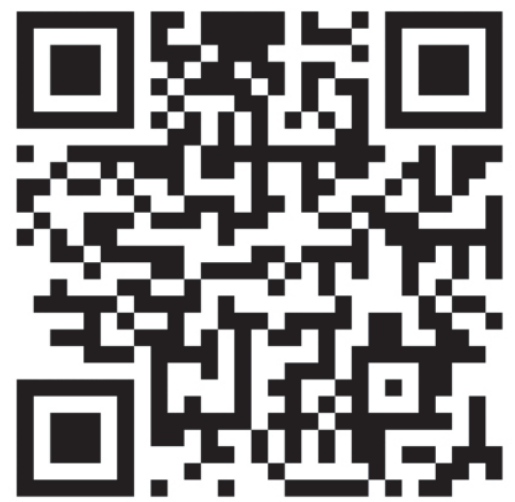

https://vimeo.com/151735928

Como parte de la propuesta metodológica para esta investigación, impulsé junto a mi colega colombiana Isabel González, un intercambio de trabajos textiles entre las tejedoras de Colombia y algunos colectivos de tejedoras en México, de manera especial se estrechó el vínculo con las tejedoras amuzgas con quienes realicé trabajo de campo. Sin embargo, se extendió el intercambio con experiencias de tejedoras urbanas como el colectivo Bordando por la Paz y la Memoria: una víctima un pañuelo en la Ciudad de México. Por otro lado, hubo un intercambio con un grupo de tejedoras de Zinacantán en Chiapas, quienes conforman el colectivo Malacate Taller Experimental Textil.

La experiencia consistió en montar una exposición titulada "Tejer con el Hilo de la Memoria: puntadas de dignidad en medio de la guerra", en la que se mostró el trabajo del colectivo Costurero por la Memoria de Sonsón de Colombia, conformado por mujeres supervivientes del conflicto armado, quienes a través de sus tejidos comenzaron a denunciar las injusticias y las historias de violencia.

Durante tres meses, de noviembre del 2014 a enero del 2015, la exposición recorrió diferentes espacios en México con la idea de socializar la experiencia a otros colectivos textiles, tejedoras y gente en general. A la par de la exposición dimos talleres de Tejido y Memoria, y organizamos una muestra audiovisual con dicha temática. 
A lo largo del recorrido, mi cámara acompañó el proceso. El documental logra rescatar aquellos momentos de mayor sensibilidad y empatía con los espectadores y participantes de los talleres. La intención principal era retribuir de alguna manera el esfuerzo de las tejedoras colombianas al enviarnos sus piezas tejidas y compartirnos sus historias. Yo quería que ellas pudieran apreciar el impacto y la resonancia que tuvo la exposición para las tejedoras mexicanas y la sociedad civil en general que tuvieron la oportunidad de asistir a la exposición o participar de los talleres.

En el 2016 tuve la oportunidad de visitar por primera vez Sonsón en Colombia y conocer a todo el costurero. Fue muy emotivo poder conocer sus casas, su pueblo y la casa de cultura donde ahora tienen el salón de la memoria, donde se reúnen una vez por semana a tejer y desarrollar sus proyectos. Me dieron la oportunidad de proyectar el documental en una sala de cine del centro cultural y pudieron apreciar todo lo acontecido en la gira de la exposición con sus trabajos.

Una de las tejedoras comentó al ver una imagen de las muñecas de Sonsón a lado de las de Xochistlahaca:

Muy bonito ver a sus muñecas revueltas con las nuestras, es como una unión. Todas juntas como una familia. A mí me gustan estos grupos porque uno aprende lo que las otras hacen y las otras aprenden lo que uno sabe. Es un compartir y uno se entretiene. Y esos raticos se nos van rápido porque cosemos, charlamos, tomamos algo y es un tiempo que nos damos a nosotras mismas (Reflexión de una de las integrantes del costurero Tejedoras por la Memoria de Sonsón después de la proyección. 8 de mayo de 2016. Antioquia).

Al finalizar los tres meses de recorrido por México con la exposición, habíamos tejido ya muchos lazos y redes entre personas. El documental, a manera de hilo conductor, relata y documenta la respuesta de la gente a la exposición y describe el trabajo de cada uno de los colectivos que visitamos. También reflexiona sobre los puentes que se tejen entre la actividad colectiva, la creatividad como medio expresivo que permite sanar y sobretodo, el potencial transformador de la realidad que tienen los espacios para crear, narrar y tejer. 


\section{Conclusiones}

La utilización de la cámara en el quehacer etnográfico, ya sea como metodología o como una forma de comunicar la experiencia del encuentro intercultural, ha trazado nuevas preguntas de investigación y rutas de conocimiento novedosas y experimentales, replanteando el tema de la mirada, la observación y los sentidos; ha significado también nuevos retos para la etnografía, la metodología y la construcción de conocimientos compartidos.

Espero que después de la lectura de este artículo acompañada de la visualización de los videos, el lector quede con una idea clara del recorrido etnográfico y creativo que se fue tejiendo a lo largo de la investigación. Así mismo, que el contenido de los documentales, reafirme la premisa de que el tejido no es sólo un pasatiempo, ni una actividad doméstica, sino un reflejo del pensamiento, un mantra repetitivo que invita a la abstracción y al descubrimiento de uno mismo.

Una de las riquezas y virtudes de este trabajo,-además de, por supuesto, estar cerca de grandes tejedoras y poder dedicar tiempo a tejer en colectivofue poder vincular, articular y entrar en contacto con diversas organizaciones y actores sociales que desempeñan sus actividades alrededor del tejido.

La estrategia colaborativa, la vinculación entre colectivos de tejedoras a través de la exposición y los talleres, así como la realización audiovisual, fueron metodología y objeto de estudio. Esto último, me permitió abordar desde una perspectiva personal y reflexiva, mi propia experiencia como tejedora, hasta lograr integrar conocimientos de otras experiencias textiles a las que me fui vinculando a través de la investigación. También fue la oportunidad de ligar subjetividades y a la vez responder a mis inquietudes etnográficas desde este complemento creativo que acompaña la escritura académica.

De esta forma, la relevancia de la realización audiovisual se cimienta en un proceso etnográfico muy orgánico, donde fui resolviendo cuestiones de distinto orden: desde no saber hablar la lengua ñomndaa, por ende, no poder generar preguntas de investigación que pudieran comprender las tejedoras; el no saber en un primer momento tejer en telar de cintura, incluso no comprender cómo se establecían las relaciones sociales entre las participantes de la cooperativa.

Los videos me permitieron integrarme en cada una de estas esferas hasta poder comprenderlas y articularlas en un discurso audiovisual. La visualiza- 
ción en colectivo con las tejedoras de cada video era el examen o la prueba de que lo que me habían compartido lo había comprendido correctamente.

La realización de los cinco videos fue más que un refugio para no perderme entre las historias de otras tejedoras, fue también la oportunidad de experimentar, ejercitar la mirada, desarrollar un estilo propio para tejer con imágenes mi recorrido en este andar etnográfico para finalmente culminar con un tejido de imágenes que fue el resultado de un encuentro intercultural donde convergen diversas subjetividades y necesidades.

El campo de la antropología visual y la antropología visual aplicada me permitieron, por un lado, llevar al terreno práctico acciones que llevan a la transformación de los espacios cotidianos, y por el otro, negociar mi presencia, presentar mi investigación frente a las tejedoras, argumentar sobre el uso de los recursos audiovisuales y también sobre la implementación metodológica, que va desde la experimentación con talleres, las muestras audiovisuales, la exposición de tejidos de Colombia en México y el intercambio de mensajes y creaciones entre diversos colectivos de ambos países. Todo este esfuerzo se fundamentó en la búsqueda de una etnografía que pone en diálogo el intercambio de experiencias, procesos reflexivos, colaborativos y creativos con el fin de comprender una actividad, un oficio manual que se ha desenvuelto en más de un contexto.

El proceso documental, incluso a veces más que la escritura etnográfica, deja ver muy claramente cómo se teje la relación entre el realizador y las personas, se puede descifrar el grado de involucramiento, la honestidad de la estructura y forma narrativa, la elección del tono en el que se narra, así como las imágenes y testimonios, y cómo todos estos elementos se combinan según la elección del autor en complicidad con los sujetos participantes para generar sentido y transmitir la experiencia etnográfica que surge del encuentro intercultural.

\section{Bibliografía}

Ardèvol, E. (1994). La mirada antropológica o la antropología de la mirada: De la representación audiovisual de las culturas a la investigación etnográfica con una cámara de video. (Tesis doctoral). Universidad Autónoma de 
Barcelona, formato electrónico de la autora (Consultado en diciembre del 2015):

https://www.researchgate.net/publication/242657337_La_mirada_antro pologica_o_la_antro pologia_de_la_mirada_De_la_representacion_audiovisual_de_las_culturas_a_la_investigac ion_etnografica_con_una_ca mara_de_video

Ardèvol, E. (2006). La búsqueda de una mirada. Antropología visual y cine etnográfico. Barcelona: UOC.

De Garay, G. (Coord.) (2013). Cuéntame tu vida. Historia oral: historias de vida. México: Instituto Mora.

Howes, D. (Ed.) (2005). The Empire of the Senses. The Sensual Culture Reader. London: Bloomsbury.

Marcus, G. E. (2001). Etnografía en/del sistema mundo. El surgimiento de la etnografía multilocal. Alteridades, 11(22), 11-127. México: UAM.

Ortega Olivares, M. (2009). Metodología de la sociología visual y su correlato etnológico. Argumentos, 22(59), enero-abril, pp. 165-184. UAM-X: México.

Pink, S. (2009). Doing Sensory Ethnography. London: SAGE Publication Ltd.

Rappaport, J. (2007). Más allá de la escritura: la epistemología en colaboración. Revista Colombiana de Antropología, 43, 197-229, enero-diciembre. Bogotá: Instituto Colombiano de Antropología e Historia.

Sennett, R. (2009). El artesano. Barcelona: Anagrama.

Vila, A. (Coord.), Grau, Jordi, Ardévol, Elisenda y Orobitg, Gemma (2008). El medio audiovisual como herramienta de investigación social. En Serie: $D i$ námicas Interculturales. Número 12. Barcelona: CIDOB.

Zirión, A. (2015). Miradas cómplices: cine etnográfico, estrategias colaborativas y antropología visual aplicada. Iztapalapa Revista de Ciencias Sociales y Humanidades, 36(78), enero-junio. México.

Fecha de recepción: 15/06/2017; fecha de aceptación: 01/08/2017; fecha de publicación: 0l/09/2017 


\title{
Investigación colaborativa y decolonización metodológica con cámaras de video
}

\author{
Collaborative research and methodological \\ decolonization with video cameras
}

\author{
Juan Carlos A. Sandoval Rivera ${ }^{1}$ \\ jcsandoval.rivera@gmail.com
}

\begin{abstract}
Resumen
El artículo reporta el desarrollo de una investigación colaborativa en donde se utilizó la metodología de video participativo como proceso educativo para documentar prácticas de conocimiento indígena en el sur de Veracruz, México. El estudio de caso describe la producción de un video documental con jóvenes indígenas y cómo el proceso de creación del video acercó a los participantes a conocer prácticas tradicionales locales y saberes socioambientales de la comunidad. El video participativo permitió documentar la pesca tradicional que se lleva a cabo en la comunidad, una actividad realizada principalmente por mujeres. El estudio encontró que el involucramiento de los jóvenes en la creación del video documental y el abordaje educativo decolonial a través del cual se realizó la colaboración, permitió a los jóvenes articularse con el contexto natural y la cultura local y valorar prácticas que buscan el bienestar humano. El estudio analiza también la relevancia del uso de cámaras de video como herramienta para el desarrollo de metodologías decoloniales en investigación en ciencias sociales.
\end{abstract}

\section{Palabras clave}

Investigación colaborativa, metodologías decoloniales, video participativo, conocimiento indígena, educación ambiental, sustentabilidad.

Forma sugerida de citar: Sandoval Rivera, Juan Carlos A. (2017). Investigación colaborativa y decolonización metodológica con cámaras de video. Universitas, $X V(27)$, pp. 161-177.

1 Investigador, Instituto de Investigaciones en Educación, Universidad Veracruzana. Orcid: 00000001-8084-282X. 


\begin{abstract}
This article reports the development of a collaborative research through the use of a participatory video methodology to document indigenous knowledge practices in southern Veracruz, Mexico. The case study describes the production of a video on livelihood practices with youth and how the process of the creation of the video took participants back to cultural experiences and environmental meaning-making. The dialogical work with participatory video enabled in depth insights that exemplified the knowledge within the context of fishing practices in local wetlands, a practice done mainly by women that had receded and was being lost in modern times. The study found that, on the one hand, it was the involvement in the participative development process of a documentary production and on the other, decolonial education processes (discussions amongst learners and fisher women) that surfaced much of the rich detail that then articulated into the local environment context and indigenous sustainability practices to enhance human wellbeing. The study found as well the relevance of the use of video cameras as a tool for the development of decolonial methodologies in social sciences research.
\end{abstract}

\title{
Keywords
}

Collaborative research, decolonial methodologies, participatory video, indigenous knowledge, environmental education, sustainability.

\section{Introducción}

En el ámbito académico es común encontrar investigaciones en las que, a través de una diversidad de métodos, se buscan respuestas a preguntas que el investigador se plantea, casi siempre, desde una perspectiva individual. En Ciencias Sociales, estas respuestas se obtienen generalmente a través de cuestionarios, entrevistas y observando a personas que se suelen denominar como informantes; a partir de las respuestas obtenidas y de lo observado, el investigador desarrolla un análisis con el que posteriormente genera conclusiones y finalmente, un reporte académico. Con la intención de cuestionar esta práctica arraigada en la academia, en la investigación que aquí se relata se buscó, además de generar conocimiento académico, fortalecer procesos comunitarios a través de un enfoque colaborativo. Se planteó así porque se partió del supuesto de que pocas personas de las que participan como informantes en un proyecto de investigación se benefician realmente de una tesis o un ar- 
tículo publicado en una revista científica. Así, esta experiencia se desarrolló buscando trascender el esquema de investigador-investigado, sujeto-objeto, autor-informante. Se propuso una investigación colaborativa (Leyva y Speed, 2008; Rappaport y Ramos, 2005) y reflexiva (Banks, 2010), en la que se buscó analizar la relevancia del uso de cámaras de video en lo que se refiere a descolonizar prácticas metodológicas de la tradición académica de investigación en ciencias sociales. Se partió de que éstas, son en sí prácticas colonizantes cotidianas y naturalizadas en comunidades rurales o indígenas. Al respecto, Dietz y Mateos (2011) argumentan que la colonialidad persiste como una de las formas más generalizadas de dominación en el mundo; por lo que reconocer el carácter colonial de las sociedades latinoamericanas permitirá intuir el carácter colonial de su sistema de saberes, de sus conocimientos y con ello, la posibilidad de generar una "decolonialidad" como respuesta (Dietz y Mateos, 2011, pp. 59-60). Las reflexiones que en este texto se presentan, se generaron a partir de un proceso que buscó generar esa respuesta decolonizante a través del uso de cámaras de video como alternativa a la investigación que busca solamente, extraer información de ciertos contextos socioculturales.

En esta investigación colaborativa se buscó generar conocimiento que pudiera ser aplicable directamente al contexto en el que se generó este conocimiento; Leyva y Speed (2008) concluyen que en una investigación colaborativa se enfrentan al menos tres problemas interrelacionados que están presentes en muchos proyectos de investigación:

1) El de la supervivencia del fardo colonial de las ciencias sociales y de la naturaleza neocolonial de la investigación científica; 2) el de la arrogancia académica producto de la 'racionalidad indolente' [...], que asume que el conocimiento científico es superior, más valioso que el producido por los actores sociales; y 3) el de la política de la producción de conocimiento que incluye, por una parte el interés y la práctica de producir conocimiento que contribuya a transformar condiciones de opresión, marginación y exclusión de los estudiados y, por otra, la elaboración de análisis académicos más ricos y profundos con base en la experiencia de co-labor (Leyva y Speed, 2008, pp. 66-67).

La descolonización de metodologías de investigación a través de proyectos colaborativos introduce una perspectiva que conduce a analizar la condición de las relaciones entre colonizadores y colonizados (Dietz, 2011) a través de estrategias descolonizantes. En este sentido, es preciso mencionar que la colonialidad se encuentra presente en muchos de los ámbitos que de ma- 
nera casi inconsciente producimos y reproducimos. Al respecto, Dietz (2011) menciona que: "la colonialidad persiste no como estructura política ni administrativa, sino como estructura de la percepción, conceptualización y práctica de la diversidad" (pp. 58-59). Por lo tanto, la actualidad y persistencia de la colonialidad en América Latina requiere de acciones con implicaciones ético-políticas tales como la necesidad de propiciar una teorización que emerja del propio contexto, orientada a lograr la decolonialidad (Dietz, 2011).

En la búsqueda de una congruencia ético-política con el planteamiento que dio sustento a la investigación (en el sentido de propiciar una descolonización a través del uso de cámaras de video), este proyecto se orientó a propiciar el descubrimiento y la recuperación de la cultura, la historia, la lengua y la identidad, con la finalidad de contribuir a la recomposición de la autoestima y la identidad indígena (Chilisa, 2012), así como de la memoria local, a través del uso de la estrategia de video participativo (Lunch y Lunch, 2006), siguiendo los principios de Rouch (1974) respecto de la Antropología compartida. Así, se propuso una investigación con dos componentes: a) un componente de gestión en el que se buscó propiciar lo mencionado y, b) un componente analítico de lo acontecido durante esta "gestión", que contribuyó al debate teórico, conceptual y metodológico de los campos de estudio de la Educación Ambiental para la Sustentabilidad (Cf. González, 2001) y la Antropología audiovisual (Cf. Grau, 2002).

La investigación se llevó a cabo en la comunidad de Zaragoza, Veracruz, México; esta comunidad, de acuerdo con el Instituto Nacional de Estadística, Geografía e Informática (2010), cuenta con un total de 10720 habitantes. En lo que se refiere a cifras relacionadas con población indígena, el total de hablantes de la lengua nahua es de 3401 . El porcentaje de hablantes del nahua en la comunidad Zaragoza es de $31.72 \%$, frente a un $68.28 \%$ que no son hablantes de la lengua local, es decir que la población nahua-hablante en la comunidad representa casi un tercio del total de la población.

\section{Metodología}

\section{Investigación colaborativa y reflexiva}

La investigación que aquí se presenta, se desarrolló a través de un abordaje reflexivo (Dietz, 2011) inspirado en el método etnográfico en el que se 
utilizaron cámaras de video como estrategia de documentación y creación audiovisual (Ardèvol, 1998). Entiendo por "reflexividad" el proceso de hacer explícitos los valores y las experiencias del investigador que influyen en la toma de decisiones que guían un proceso de investigación. Desde esta mirada, quien conduce la investigación es el principal instrumento de colecta y análisis de datos. Es decir, se explicita la conciencia del investigador sobre sí mismo, "de la realización de su investigación y de la respuesta a su presencia; es decir, el investigador reconoce y evalúa sus propias acciones, así como la de los otros" (Banks, 2010, p. 75). La reflexividad del investigador se confronta con la reflexividad de los participantes en el proceso de investigación a través de la interacción. Ésta, permite la emergencia de una situación reflexiva bilateral que afecta a los actores que participan en un proceso de investigación como el que aquí se relata y que lo va modificando en la medida que la interacción se vuelve más compleja por las maneras culturales en que conferimos significados a fenómenos sociales (Grau, 2002).

Desde este posicionamiento, la metodología utilizada en este trabajo de investigación fue netamente cualitativa. Este planteamiento cualitativo tuvo un carácter humanista en el sentido propuesto por Plummer (1983): el foco del estudio se centró en la búsqueda de lo subjetivo, los significados y los sentimientos de las personas involucradas en el proceso. En esta aproximación cualitativa se retomó la clasificación de Gummesson (1991) sobre el paradigma hermenéutico, en el que se menciona que el investigador es un actor que también quiere experimentar en su interior el fenómeno que está estudiando, por lo tanto, acepta la influencia tanto de la ciencia como de la experiencia personal para diseñar, desarrollar y generar interpretaciones en torno a los ámbitos de investigación que estudia (Berg, 2007).

Un elemento clave de esta investigación fue el enfoque colaborativo (Leyva y Speed, 2008; Rappaport y Ramos, 2005; Flores, 2012) desde el que se planteó. Sin embargo, plantear un enfoque colaborativo para una investigación académica resultó una tarea doblemente compleja. Primero, porque no se trató solamente de hacer una "intervención" que contribuyera a resolver una problemática local a partir de propuestas generadas y evaluadas desde los propios grupos involucrados (Smith, 1999), sino que a través de lo acontecido en esa intervención, se buscó generar un reporte de investigación que sería evaluado por un comité académico. En este sentido, desarrollar un proyecto de investigación que se basó en un trabajo de intervención implicó caminar en dos pistas y trabajar en varios niveles. Por un lado, se desarrolló 
una estrategia de intervención que fuera culturalmente pertinente y que contribuyera al fortalecimiento de procesos comunitarios en el sentido de Smith (1999) y que, a partir de los resultados obtenidos, se satisficiera la necesidad por la cual se diseñó la intervención (la realización de un video documental en colaboración con jóvenes locales). Por el otro, el reto de desarrollar una estrategia teórica y metodológica con la que se pudiera generar un documento con las características necesarias para ser evaluado por un comité científico y con el que se pudiera acceder un grado académico.

¿Qué tipo de trabajo colaborativo fue el que se desarrolló y qué fue lo que se quería lograr con este? El posicionamiento ético-político en relación con la generación y aplicación del conocimiento fue un componente que quería respetar y hacer valer. Si bien, al principio del proceso se planteó un proyecto académico, en todo momento quedó abierta la posibilidad de que tanto los objetivos como el abordaje metodológico fueran discutidos y negociados con los actores con los que se deseaba colaborar. Al principio, esta estrategia generó dudas en cuanto a la rigurosidad científica con la que se planteaba la propuesta, ya que no se identifican con facilidad experiencias de investigación doctoral en las que el estudiante tenga que negociar su propuesta con actores locales. Desde este punto de vista, en el proceso realizado no hubo "objetos de estudio", sino sujetos que pusieron sus reglas sobre la mesa, los cuales se fueron involucrando según sus intereses. Esto implicó desarrollar una colaboración en la que se propiciara una intervención lo menos violenta posible y que se sustentara en un diálogo en el que todas las voces pudieran expresar su visión del mundo desde lo propio; asimismo, implicó visibilizar las asimetrías y propiciar la reciprocidad entre los participantes que comparten un mismo proyecto audiovisual (Rouch, 1974).

Desarrollar una investigación colaborativa con un sentido educativo y político, es una estrategia que al generar conocimiento sobre una realidad y validarlo de una manera participativa, aporta los elementos que a su vez le dan sustento. No se puede dejar de lado la discusión de que la validación de este tipo de generación de conocimiento implica también concebir criterios de validación no convencionales, los cuales se evalúan en función de lo planeado y lo logrado, a partir de los criterios diseñados por los propios participantes en relación con el proceso llevado a cabo. En este supuesto, las siguientes preguntas (Denzin y Lincoln, 2005) fueron clave para poder validar la investigación desde una mirada participativa: ¿Qué tipo de investigación queremos realizar? ¿Para quién es la investigación realizada? ¿Qué ha- 
brá cambiado una vez finalizada la investigación? ¿Quién la llevará a cabo? ¿Cómo queremos hacer la investigación? ¿Cómo sabremos que la investigación es relevante? ¿Quién será el poseedor final de la investigación? ¿A quién beneficiará?

Para construir colectivamente conocimiento en un proyecto de investigación colaborativo como el que se llevó a cabo, el principal reto radicó en articular los diversos tipos de saberes que convergieron en el contexto en el que se desarrolló la investigación. En este escenario, en donde se planteó la construcción colectiva de conocimiento mediante el uso de cámaras de video, los sujetos que se involucraron, tomaron un rol activo y participante: la investigación no estuvo restringida al investigador, sino que todos los participantes tuvieron la capacidad de investigar y con ello contribuir desde sus propios análisis a las respuestas que la investigación buscó responder. Siguiendo a Rockwell (2009), en esta investigación se intentó documentar lo "no-documentado" de una realidad social específica, a través de miradas interpretativas compartidas.

Durante la colaboración se generó un "escenario de investigación" que posteriormente se analizó. Este "escenario" (el proceso de creación de un documental participativo) se co-construyó con los actores que se involucraron en el proceso. De esta manera, como investigador, no llegué a indagar sobre algún fenómeno que acontecía "naturalmente" en un contexto (como en la aproximación etnográfica más clásica), sino que mi "objeto de estudio" lo construí de manera colaborativa con esos "otros" actores. En este sentido, los resultados, productos y reflexiones en esta dimensión metodológica no tuvieron una autoría individual, sino compartida. Los materiales producidos (en audio y video) durante el proceso constituido por un curso-taller, la estrategia de planificación del proceso de producción del video documental, la metodología para su diseño y su ejecución, así como los aprendizajes y reflexiones en torno al proceso llevado a cabo, son propiedad del colectivo que participó. Considero pertinente mencionar aquí la distinción entre el tipo de conocimiento que se generó en ambas dimensiones: para la dimensión colaborativa, el conocimiento generado fue de carácter compartido (del colectivo) y, en la dimensión etnográfica, de carácter individual (del investigador).

\section{El video como estrategia educativa y de investigación}

Como ya se ha mencionado, el propósito de la investigación colaborativa fue detonar un diálogo de saberes (Leff, 2003) entre actores comunita- 
rios a través del uso de tecnologías audiovisuales, particularmente del uso de video como herramienta educativa y de investigación. La incorporación del proceso de producción de un documental y su uso como herramienta educativa en el proyecto de investigación derivó de varias razones. La primera, porque fue una solicitud expresa realizada por un grupo de mujeres de la comunidad en donde se trabajó, a quienes me había acercado para invitarlas a participar en el proyecto de investigación. Ellas expresaron que les gustaría participar en el proyecto dando algunos testimonios para un posible documental y en la definición del tema del mismo, pero no a participar directamente en el equipo de producción, rodaje ni edición de la misma. En realidad, las señoras no querían colaborar porque creían que ese tipo de actividades deberían estar enfocadas a los jóvenes y no a las personas mayores. Las señoras estaban interesadas en colaborar en el proyecto, pero de una manera indirecta; estaban dispuestas a brindar información sobre sus saberes, pero que los indicados para realizar el trabajo de producción de una película tenían que ser los jóvenes. El video como producto no fue el objeto de estudio de la investigación, sino el llegar a él, el construirlo de manera colectiva a partir de ideas de actores con diferentes perspectivas, opiniones y experiencias. En ese sentido, el diálogo para llegar a definir qué tipo de video se requería implicó propiciar discusiones con fondo conceptual, político y estético, lo cual representó un reto metodológico para la investigación, ya que se tenían que mostrar y poner a dialogar no sólo las ideas, sino también las percepciones estéticas y sensibilidades de cada uno de los participantes en un contexto culturalmente diverso. La incorporación del video en el proyecto emergió también de las entrevistas que sostuve con algunos habitantes de la comunidad de Zaragoza, quienes me manifestaron la importancia de este para comunicar sus saberes tradicionales con las nuevas generaciones. Era común escuchar que sus saberes se están perdiendo y que sería de mucha importancia recuperarlos y mostrarlos a los jóvenes para que reconocieran sus orígenes y su propia cultura.

Por otro lado, consideré que el video podía funcionar como una herramienta para registrar saberes tradicionales, que pudieran mostrar cómo la cultura local y los saberes ancestrales contribuyen a la conservación de especies y ecosistemas sin necesidad de tener contacto con políticas e iniciativas relacionadas con la sustentabilidad provenientes principalmente del Estado o de los sectores académicos. La justificación de incorporar el video en el proyecto emergió de la necesidad de contribuir en el empoderamiento de 
quienes participaran en el proyecto, de difundir saberes y de exigir una gobernanza ambiental (Brenner, 2010) con base en prácticas sustentables basadas principalmente en saberes locales. En este mismo sentido, es preciso mencionar que en la disciplina de la antropología visual (Grau, 2002; Flores, 2012) encontré elementos importantes para cuestionarme metodológicamente el papel del actor que video-documenta aspectos de la vida de ciertos grupos culturales como una manera de hacer investigación (Ardèvol, 1998).

Durante las primeras incursiones en el campo me regresé a revisar las preguntas que previamente había concebido y que se relacionaban con los saberes existentes en la comunidad y con la transmisión de los mismos a través de las generaciones. Así, como me interesaba identificar los saberes ancestrales relacionados con el manejo de los ecosistemas locales, también me interesaba conocer si estos saberes se estaban transmitiendo entre las generaciones. Si esto era así, resultaría importante para el estudio, identificar mediante qué procesos sucedía esta transmisión de saberes de los ancianos hacia los jóvenes. Los resultados de la aplicación de un primer cuestionario de entrevista a sabedoras locales mostraron que, si bien aún hay presencia en la comunidad de personas que poseen saberes valiosos, éstas son actualmente personas adultas o ancianos que ya no desarrollan actividades tradicionales como la pesca, debido principalmente a su edad. Por otro lado, encontré que a los jóvenes ya no les interesaba conocer lo que sabían sus abuelos, ya que era cada vez más difícil observar que los jóvenes se acercaran a preguntarles a los abuelos sobre su propia cultura, sobre su lengua o sobre la historia de su comunidad. Se percibía en el discurso que a los jóvenes de ahora les interesa más salir hacia la ciudad en lugar de quedarse en su pueblo y contribuir a su desarrollo.

\section{Curso "Saberes locales y video participativo"}

Con base en lo planteado con anterioridad, se lanzó una convocatoria a jóvenes de la comunidad de Zaragoza para que se integraran en el proyecto y pudieran participar en el diseño, producción y difusión del video a desarrollar. Como resultado de esa convocatoria, se configuró un grupo de diez participantes con los que finalmente se desarrolló la colaboración. Con este grupo, se realizó un curso-taller sobre saberes locales, técnicas de investigación, lenguaje cinematográfico, video participativo y edición de video, al que se denominó "Saberes locales y video participativo" el cual tuvo un total de 40 horas. En éste, se trabajaron aspectos concernientes a la planeación 
de la producción, aspectos técnicos y se incorporaron además, temáticas relacionadas con la relevancia social y política del uso de video participativo y la importancia de la documentación de saberes locales en relación con el manejo del territorio. Para fortalecer el trabajo de recolección de datos sobre los saberes de la comunidad, y con ello perfilar el tema del video documental a realizar, se trabajó una sesión sobre métodos de investigación en donde se incluyeron la entrevista y la observación participante, y sobre instrumentos para el trabajo de campo como el cuestionario, la fotografía y el uso de video como método de investigación. En el marco de esta temática los jóvenes participantes realizaron entrevistas a diversos actores de la comunidad, las cuales se analizaron colectivamente. Se procedió a escuchar los audios de las entrevistas y a comentar las similitudes entre entrevistas y temáticas relevantes de su contenido, con la finalidad de ir perfilando el guion del documental. Como resultado del análisis de las entrevistas realizadas, se detectaron tres posibles temáticas a abordar: 1) la visión de los jóvenes respecto a la pesca tradicional en la actualidad, es decir, mostrar que los jóvenes ya no están interesados en esta actividad tradicional porque tienen perspectivas de desarrollo personal relacionados con cursar una carrera profesional; 2) la transformación de las prácticas de la pesca tradicional a través del tiempo, es decir, mostrar cómo se realizaba la pesca en el pasado y cómo se realiza la pesca ahora; y 3) leyendas locales sobre la relación de la pesca con el cocodrilo. Una vez establecidos los temas que se iban a abordar en el documental, se procedió a planificar el guion, así como a estructurar el storyboard para planificar con detalle cada una de las secuencias y tomas necesarias a lograr durante la fase de rodaje.

Una vez definida la estructura de las secuencias, cada participante eligió entre dos y tres secuencias para dirigir, dando con ello, la oportunidad a cada participante de aportar su punto de vista individual a cada una de las tomas de las secuencias seleccionadas. Durante el rodaje se pudo generar material correspondiente a las secuencias planeadas. Se realizaron entrevistas en video a pescadoras tradicionales y a estudiantes de la comunidad. Se documentaron también parajes de la comunidad de Zaragoza, así como preparativos para la pesca y, por último, se documentó una faena de pesca realizada por mujeres de la comunidad. Durante la faena de pesca, las mujeres se dedicaron a mostrar toda su experiencia y a compartir saberes con los documentalistas en cuanto a la técnica de pesca y en lo que se refiere a saberes tradicionales y retos socioambientales asociados con esta actividad. Al ini- 
cio, los jóvenes se dedicaron sólo a participar video-documentando la faena, sin embargo, poco a poco se fueron interesando en cómo las pescadoras realizaban sus actividades, dejando por momentos de lado la cámara y pidiendo a ellas que les enseñaran a utilizar el matayahual, la red en forma de aro que utilizan para pescar. Como se mencionó previamente, la video-documentación de la faena de pesca fue la última actividad del rodaje. Una vez que cada director confirmó que contaba con las tomas para cada secuencia, el rodaje se dio por concluido. Se procedió a revisar el material, analizando el contenido en relación con la temática abordada y a la calidad técnica del material, como aspectos de audio y video. Una vez analizado el material, se planificó y se llevó a cabo la post-producción. Así, después de aproximadamente 40 horas de trabajo reflexivo y capacitación en el marco del curso-taller, 40 horas de planeación y rodaje, 10 horas de material grabado y más de 30 horas de trabajo de post-producción, surgió el primer producto del curso-taller: el documental participativo titulado "Los Herederos de Achaneh" (Sandoval et al., 2013) ${ }^{2}$.

\section{Análisis y resultados}

Con la finalidad de analizar el impacto del proyecto, retomo la propuesta de Smith (1999), quien formula una serie de principios rectores para proyectos como el que aquí se ha descrito. Estos principios permiten visualizar aspiraciones diferenciadas, históricamente subordinadas y políticamente no alineadas a las tendencias hegemónicas. A partir de algunos principios de su propuesta se analiza, desde una mirada crítica, los resultados del proceso educativo en el marco de la producción del video documental. Particularmente me interesa resaltar cómo los jóvenes, al haber participado en este proceso, transformaron sus percepciones en cuanto a su comunidad, su entorno natural, su cultura y su propia capacidad para organizarse.

El primer principio que retomo de Smith es el de "intervenir". Implica que la investigación sea entendida literalmente como el proceso de ser proactivo respecto al cambio. En ese sentido, la comunidad invita al proyecto y define sus parámetros. Las instituciones involucradas deben estar dispuestas a cambiar, redirigir políticas, diseñar nuevos programas y capacitar

2 Cf. https://www.youtube.com/watch?v=LS9BEyQxyTY 
a su grupo de forma diferente. La intervención va dirigida a cambiar a las instituciones que gestionan proyectos con pueblos indígenas y no a cambiar los pueblos indígenas para que estos “encajen” en las estructuras (1999, p. 145). A la luz de este primer principio, resalto que la gestión fue desarrollada como un proceso permanente de reflexión colectiva sobre los saberes que han sido desplazados o invisibilizados. El grupo de pescadoras tradicionales y los jóvenes definieron los parámetros de realización del proyecto. Bajo esta lógica, se ejerció un papel de coordinación, negociación y no de imposición de objetivos. De esta manera, el posicionamiento y la estrategia metodológica se orientaban hacia la reflexión y, en la medida de lo posible, a la transformación de las estructuras y procedimientos que actores externos proponen/imponen a la luz de lógicas monoculturales.

Un segundo principio es el "trabajo en redes". Esta manera de operar se ha convertido en un medio eficaz para estimular el flujo de información. Crear redes es construir conocimiento con base en relaciones y conexiones. Es una forma de establecer contactos entre comunidades marginales. Por definición, su marginación las excluye de participar en las actividades de los sectores hegemónicos no indígenas que controlan las formas y medios de comunicación. Asuntos con un impacto directo en las comunidades indígenas, como por ejemplo el Protocolo de Nagoya, no han sido comunicados de manera eficiente y culturalmente pertinente a los pueblos indígenas. Éstos, no tendrían conocimiento de dichos acuerdos ni de su impacto si no fuera por el poder del trabajo en redes. Este principio es un proceso para construir relaciones y diseminar conocimiento (Smith, 1999, p. 157). Retomándolo, un resultado del proceso educativo fue la generación y el fortalecimiento de redes locales a partir de la producción del video documental. Su producción permitió generar nuevas redes de colaboración de los jóvenes para futuros proyectos audiovisuales, así como fortalecer las redes existentes de las pescadoras como colectivo. El trabajo en redes se ha convertido en un medio eficaz para estimular el conocimiento del entorno y de sus problemáticas, tales como la contaminación de la laguna en donde se realizan las faenas de pesca, y así sensibilizar a la gente sobre asuntos de interés. El fortalecimiento de las redes locales ayudó a construir conocimiento con base en relaciones y conexiones. Ahora los jóvenes vislumbran una estrategia potencial para establecer contactos entre comunidades cercanas con problemáticas comunes.

Un tercer principio es "crear". Se refiere a trascender el modo básico de supervivencia a través del uso de un recurso o capacidad que toda co- 
munidad indígena ha mantenido a través de la colonización: la habilidad de crear y ser creativo (Smith, 1999, p. 157). Durante el desarrollo del video documental se manifestaron diferentes ámbitos de creatividad como la creación del documental, que de por sí ya es un producto que resguarda el saber intangible que existe en la comunidad. Este saber no sólo se "congela" en el tiempo a través de una estrategia audiovisual, sino que lo ahí expuesto muestra prácticas y saberes que las comunidades indígenas crean y reproducen en su quehacer cotidiano. En estos saberes y prácticas de los pueblos indígenas existen pistas que pueden contribuir a la construcción de sociedades sustentables.

Otro principio es el de "nombrar", el cual significa renombrar el mundo usando los nombres indígenas originales, como por ejemplo los lugares (toponimia). Esto implica tener el control sobre los significados. Para las comunidades, hay realidades que sólo pueden ser nombradas en las lenguas indígenas; hay conceptos que no pueden ser capturados por otras lenguas (Smith, 1999, pp. 157-158). Nombrar situaciones que aparecen en el documental utilizando palabras indígenas del idioma local me parece un acierto en términos del fortalecimiento de la cultura local. Durante el trabajo colectivo, surgieron varios conceptos indígenas que podrían ser significativos en el mundo no indígena. Enunciaré un ejemplo: durante la actividad de la pesca, las pescadoras hablan entre ellas, ríen a carcajadas, se hacen bromas, cuentan anécdotas graciosas y se divierten, se distraen. Tapuluhtiá es el nombre que ellas dan a esta actividad de "recrearse" fuera de la mirada de los esposos, de los hijos y de la comunidad. Una razón importante para ir a pescar es, por supuesto, la oportunidad de complementar la dieta familiar o ganarse algún recurso económico extra. Sin embargo, la pesca no sólo se realiza desde una perspectiva económica o alimentaria. Aunque la pesca no sea buena, por el solo hecho de ir a recrearse (tapuluhtiá), la travesía, el esfuerzo y el tiempo que se requiere para llegar a los sitios de pesca, son considerados como actividades terapéuticas que fortalecen los lazos y la cohesión entre las mujeres que participan en la faena.

Así, los resultados arrojan pistas metodológicas para quienes se interesan en decolonizar las prácticas de investigación que se desarrollan en contextos rurales e indígenas, teniendo como eje central lo educativo y el fortalecimiento de la identidad cultural propia de los pueblos originarios. De esta manera, no sólo se generó conocimiento en torno a los saberes y a la producción audiovisual, sino que también se coadyuvó al fortalecimiento de 
la autoestima, la identidad y las capacidades organizativas y de toma de decisiones de los involucrados en el proyecto.

\section{Conclusiones}

En un proceso colaborativo como el llevado a cabo se generaron aprendizajes durante la planeación e implementación del mismo y no sólo al final. En esta investigación se utilizaron estrategias participativas para planificar, ejecutar y evaluar las acciones realizadas. Se concluye que visibilizar y potenciar aprendizajes es elemental para poder hacer significativo un proceso y con ello poder valorar si ha sido exitoso y relevante. Un aspecto relevante del proceso educativo en esta experiencia fue que la aproximación y aprehensión de la realidad es siempre más compleja en función de las múltiples visiones que participan en la construcción de múltiples perspectivas. En un proceso colaborativo aprendemos unos de otros, aprendemos de las visiones que hemos o se han construido en otros contextos y en otras experiencias. Sin embargo, aprender juntos en un enfoque colaborativo no es fácil, en muchas ocasiones es necesario deconstruir ciertas afirmaciones que dificultan esa construcción colectiva de conocimientos. Entre estas afirmaciones encontramos que no en pocas ocasiones se sobrevalora el conocimiento que ha sido producido dentro de los cánones académicos eurocentristas. Es decir, a veces, un bloqueo para un aprendizaje colaborativo es el carácter "incuestionable" adjudicado a los aspectos teóricos, metodológicos y técnicos generados en instituciones hegemónicas como las universidades, las organizaciones internacionales, etc., relacionados con lo productivo, lo pedagógico, con lo cultural y con lo ambiental. Este bloqueo hace invisible que en los propios saberes locales y en las experiencias que se realizan al margen de la academia y de las universidades, también existe conocimiento que puede ser pertinente para resolver problemas a los que nos enfrentamos en la cotidianidad.

Por otro lado, al tratarse de una investigación con dos dimensiones metodológicas (etnográfica por un lado y colaborativa por el otro), se tuvo que realizar un trabajo etnográfico reflexivo en el que se analizó una experiencia de intervención desarrollada de manera colectiva. Desde el posicionamiento ético-político en el que se sustentó la propuesta, lo que se buscó por un lado, fue realizar una colaboración horizontal para contribuir a fortalecer y reva- 
lorar la identidad indígena local; y por el otro, cuestionar desde la práctica, posicionamientos epistemológicos hegemónicos relacionados con la generación de conocimiento. Lo que se analizó en esta investigación no fue la "naturalidad" de las prácticas sociales de un grupo cultural, sino un proceso construido de manera colaborativa. Este proceso se construyó a partir de una colaboración en la que los actores involucrados generaron colectivamente procesos de inter-aprendizaje (Gasché, 2008). En estas interacciones, diálogos y negociaciones, se generaron conocimientos que fueron relevantes para los participantes involucrados. Una parte de mi papel como investigador consistió en identificar, potenciar y hacer visibles estos aprendizajes significativos, con la finalidad de que facilitaran la construcción de perspectivas críticas y propositivas en torno a problemáticas y fortalezas comunitarias a los participantes del proceso. El uso de cámaras de video como práctica descolonizadora permitió generar dos tipos de productos: el video documental que se realiza y los aprendizajes que se generan durante el proceso de creación. En este sentido, utilizar cámaras de video en investigación colaborativa permitió no solo documentar prácticas sociales sino detonar procesos educativos pertinentes y relevantes para los contextos en los que estos se generan. El video como herramienta de documentación y el diseño de proyectos de producción audiovisual son herramientas útiles para el desarrollo de proyectos de gestión educativa en contextos de diversidad cultural, además de ser un ámbito que resulta de gran interés para los jóvenes que viven en comunidades rurales e indígenas como en la que se desarrolló esta experiencia. El uso de cámaras de video es un método que puede dar voz al colonizado (Chilisa, 2012) y encaminar sus preocupaciones en acciones para la transformación social y ambiental. La sistematización de la experiencia que aquí se menciona, aporta elementos metodológicos para educadores interesados en fortalecer la identidad indígena, revalorar y documentar saberes tradicionales y fomentar la reapropiación de aspectos culturales clave para la sustentabilidad de los pueblos indígenas. La gestión educativa para la producción de materiales audiovisuales es una estrategia que se puede utilizar en diversos contextos, no sólo en comunidades rurales, sino también con actores de poblaciones urbanas. En esta experiencia, el trabajo se centró en la temática de los saberes tradicionales; no obstante, esta propuesta de pedagogía descolonizante tiene el potencial para utilizarse a la luz de otras temáticas y con otros grupos de edad. 


\section{Bibliografía}

Ardèvol, E. (1998). Por una antropología de la mirada: etnografía, representación y construcción de datos visuales. Revista de dialectología y tradiciones populares, 53(2), 217-240. (http://rdtp.revistas.csic.es/index.php/rdtp/article/viewFile/396/400) (2017-03-12).

Banks, M. (2010). Los datos visuales en investigación cualitativa. Madrid: Ediciones Morata.

Berg, B. L. (2007). Qualitative Research Methods for the Social Sciences 6th Edition. Boston: Allyn and Bacon.

Brenner,L.(2010). Gobernanza ambiental, actores sociales y conflictos en las Áreas Naturales Protegidas mexicanas. Revista mexicana de sociología, 72(2), 283310.(http://www.scielo.org.mx/scielo.php?script=sci_arttext\&pid=S018825032010000200004\&lng=es\&tlng=es) (2016-05-09)

Chilisa, B. (2012). Indigenous Research Methodologies. London: SAGE.

Denzin, N. K. y Y. S., Lincoln (2005). The SAGE handbook of qualitative research. Third Edition. Thousand Oaks, London, New Delhi: SAGE.

Dietz, G. (2011). Hacia una etnografía doblemente reflexiva: una propuesta desde la antropología de la interculturalidad. Revista de Antropología Iberoamericana, 6(1), 3-26. (http://www.redalyc.org/pdf/623/62321332002.pdf) (2017-01-17).

Dietz, G. y Mateos Cortés, L. S. (2011). Interculturalidad y educación intercultural en México: un análisis de los discursos nacionales e internacionales en su impacto en los modelos educativos mexicanos. México: SEP.

Flores, C.Y. (2012). Derecho maya y video comunitario: experiencias de antropología colaborativa. Iconos Revista de Ciencias Sociales, 42, 71-88. (http:// www.redalyc.org/articulo.oa?id=50923292005) (2015-09-11).

Gasché, J. (2008). La motivación política de la educación intercultural indígena y sus exigencias pedagógicas. ¿Hasta dónde abarca la interculturalidad? En Jorge Gasché, María Bertely y Rossana Podestá (Coords.), Educando en la diversidad. Investigaciones y experiencias educativas interculturales y bilingües (pp. 65-107). Quito: Abya-Yala.

González Gaudiano, E. (2001). Otra lectura de la historia de la educación ambiental en América Latina, Revista Desenvolvimento e Meio Ambiente, 3, 141158. (www.ecologiasocial.com/biblioteca/GonzalezGhisotiraEducAmbALat.pdf) (2015-10-11).

Grau-Rebollo, J. (2002). Antropología audiovisual. Barcelona: Bellaterra. 
Gummesson, E. (1991). Qualitative Methods in Management Research. Newbury Park, California: Sage Publications.

Instituto Nacional de Estadística, Geografía e Informática (2010). Censo de población y vivienda 2010. En línea: http://www3.inegi.org.mx (2015-11-17).

Leff, E. (2003). Racionalidad ambiental y diálogo de saberes: sentidos y senderos de un futuro sustentable. Desenvolvimento e meio ambiente, 7, 13-40. (http://revistas.ufpr.br/made/article/download/3042/2433) (2016-09-12).

Leyva Solano, X. y Speed, S. (2008). Hacia la investigación descolonizada: nuestra experiencia de co-labor. En Xochitl Leyva, Araceli Burguete y Shannon Speed (Coords.), Gobernar (en) la diversidad: experiencias indígenas desde América Latina. Hacia la investigación de co-labor (pp. 65-107). México: CIESAS, FLACSO.

Lunch, N. y Lunch, C. (2006). Una mirada al video participativo. Manual para actividades de campo. Oxford: InsightShare.

Plummer, K. (1983). Documents of life: An introduction to the problems and literature of a humanistic method. Londres: Allen \& Unwin.

Rappaport, J. y Ramos, A. (2005). Una historia colaborativa: retos para el diálogo indígena-académico. Historia Crítica, 29, 39-62. (http://www.scielo.org. co/scielo.php?script=sci_arttext\&pid=S0121-16172005000100003\&lng $=\mathrm{es} \& \operatorname{lng}=\mathrm{es})(2016-09-12)$.

Rockwell, E. (2009). La experiencia etnográfica: historia y cultura en los procesos educativos. Buenos Aires: Paidós.

Rouch, J. (1974). The camera and Man. En Paul Hockings (Ed.), Principles of Visual Anthropology (pp. 53-71). New York: Mouton de Gruyter.

Sandoval, J.C. et al. (2013). Los herederos de Achaneh. [En línea] México: La Milpa Producciones.

Smith, L. T. (1999). Decolonizing methodologies. Research and indigenous peoples. Nueva York: Zed Books.

Fecha de recepción: 25/05/2017; fecha de aceptación: 07/08/2017;

fecha de publicación: 01/09/2017 



\title{
Media-médium: entre la etnografía y el cine comunitario
}

\author{
Media-medium: Between Ethnography \\ and Communitarian Cinema
}

\author{
Carolina Soler ${ }^{1}$ \\ carolinasolerc@gmail.com
}

\begin{abstract}
Resumen
A través de la narración de una serie de experiencias etnográficas de campo vividas durante la realización de cine comunitario con indígenas, la autora propone explorar las implicancias del cine más allá del corte final de la obra producida, e indaga sobre el proceso cinematográfico y las diferentes dimensiones de lo social que lo atraviesan. Los ejes no son ni la cámara ni su operador, sino del proceso mayor de abordar un proyecto cinematográfico comunitario. El final del artículo hace referencia a la expansión del film fuera de sus límites temporales y físicos, a la idea de película en continua realización y a la proyección como performance que completa al filme.
\end{abstract}

\section{Palabras clave}

Cine comunitario, indígenas, trabajo de campo etnográfico, Chaco, Amazonía, Antropología visual.

\begin{abstract}
Through the ethnographic account of a series of field experiences lived during the production of communitarian cinema with indigenous peoples, the author proposes to explore the implications of cinema beyond the final cut of the work and inquiries about the cinematographic process and the different dimensions of the social which cross through it. At the end, she refers to the expansion of the film outside its temporal and physical limits stating that films are in continuous realization and that their projection is a performance which completes them.
\end{abstract}

\section{Keywords}

Communitarian Cinema, Indigenous peoples, Ethnographic Fieldwork, Chaco, Amazon, Visual Anthropology.

Forma sugerida de citar: Soler, Carolina (2017). Media-médium: entre la etnografía y el cine comunitario. Universitas, $X V(27)$, pp. 179-194.

1 Magister en Antropología y Etnología EHESS (École des Hautes Études en Sciences Sociales). Becaria doctoral de CONICET (Consejo Nacional de Investigación en Ciencia y Técnica). Doctorante en Antropología en cotutela Universidad de Buenos Aires, Argentina. École des Hautes Études en Sciences Sociales, Francia. Orcid: 0000-0003-3026-2813. 
A la memoria de Patricio Taish, cineasta y amigo shuar

\section{Introducción}

Hemos escuchado más de una vez la historia de cómo la antropología y el cine han mantenido un estrecho vínculo desde sus orígenes (De Brigard, 2003; Marcus y Ruby, 2011; Ruby, 2000; Ardèvol, 1994). También podría alegarse que el cine se funda en el entusiasmo analítico de algunos fotógrafos -como Eadweard Muybridge y Étienne Jules Marey-por indagar sobre el movimiento tanto de los animales como de los seres humanos. En la primera mitad del siglo XX, los antropólogos que consideraron la cámara como una herramienta para la investigación vieron en el registro mecánico del cine una forma fructífera de conservar imágenes en movimiento de rituales y gestualidades de hombres de culturas lejanas, ante la avanzada de un occidente moderno que amenazaba con llevárselo todo (Bateson y Mead, [1942] 1993). Mead, en su texto Visual Anthropology in a Discipline of Words ([1974] 2003), lanzó una especie de proclama en la que pedía a los antropólogos que tomaran las cámaras registraran horas de rushes sin editar que pudieran servir para revisar meticulosamente, una y otra vez, gestos y conductas de pueblos indígenas. Proponía el registro fílmico como un observador mecánico, una suerte de cine de "rescate" de un mundo que parecía desvanecerse.

Así como los instrumentos de mayor precisión nos han enseñado más sobre el cosmos, un buen registro de estos preciosos documentos culturales puede iluminar nuestro conocimiento y nuestra apreciación de la humanidad (Mead, [1974] 2003, p. 10, la traducción es propia).

A partir de la llamada “crisis de la representación” en antropología-desde mediados de los años 1970-, nuevas voces empezaron a cuestionar estos usos de la cámara, poniendo en discusión la supuesta autenticidad de su registro o, mejor, poniendo en evidencia el juego de artificios en la construcción del relato audiovisual, el establecimiento de relaciones de poder asimétricas que se generaban a través del cine y la imposición de discursos sobre un "otro" generalmente mudo, en el seno una disciplina nacida desde las entrañas del proyecto colonialista de occidente (Piault, 2000; Ruby, 2000; Rony, 1996; Nichols, 1997). A lo largo de estos vaivenes -entre la reflexión 
crítica, la producción acrítica y la experimentación absorta-, distintos antropólogos se aproximaron al audiovisual incorporando la figura del filmmaker $^{2}$ a la disciplina, para fundar, entre límites difusos y múltiples confluencias, lo que denominamos antropología visual ${ }^{3}$. La cámara se impuso como una herramienta para el estudio antropológico, y el filme -hijo menor del texto académico- comenzó a reclamar un mayor estatus (Mead, [1974] 2003; Ruby, 1991). En ese devenir se fue creando un espacio de reflexión sobre el registro de la imagen y el sonido y sobre las relaciones sociales -actuales e históricas- que se tejen en la fabricación de estos registros.

La antropología visual incorporó progresivamente nuevas perspectivas e intereses para discutir los vínculos que se establecen en la construcción de las imágenes sobre los "otros"-fijas o en movimiento, con o sin sonido-, para ir de a poco disolviendo las distancias entre el sujeto investigador y los sujetos investigados. Asimismo, la cámara irá cambiando de manos, para registrar imágenes construidas por los "otros" y con los "otros". Un punto de partida posible a esto ha sido la iniciativa comandada por Sol Worth, John Adair y Richard Chalfen, cuando en junio de 1966 les enseñaron a los navajos (diné) a utilizar cámaras de 16 mm (Worth y Adair, 1970 y 1972). Sin embargo, más allá del hito inaugural que significó esa experiencia, lo que ocurrió no dejó de ser un hecho aislado sin un desarrollo inmediato posterior. En Latinoamérica, en cambio, el uso del video por parte de indígenas surgió como un movimiento social y asumió en muchos casos una posición política crítica, con miras a la autodeterminación y a la revitalización cultural; bajo la denominación "video indígena"4 se formó una importante corriente en torno a la realización audiovisual a lo largo del continente americano (Salazar y Córdova,

2 Término que Jean Rouch prefería al de realizador, ya que conjugaba la tarea del etnocineasta, que trabaja solo, sin equipo (Colleyn, 2004, p. 387).

3 También denominada antropología audiovisual. Conservo aquí el adjetivo visual, debido a que posee una mayor profundidad histórica y, por ello, brinda la posibilidad de rastrear sus antecedentes.

4 No hay un término unificado que haga referencia a la apropiación de herramientas audiovisuales por parte de los indígenas. En Brasil, por ejemplo, se habla de vídeo índio (Carelli, 2011); en Estados Unidos, de indigenous media (Ginsburg, 1991), y en México, de video indígena (Wortham, 2013). En Nueva Zelanda, los maoríes hablan sencillamente de cine (Gauthier, 2008), aunque es cierto que sus realizaciones son más cercanas al cine industrial. Como alguna vez dijo Claude Chavrol, "un cinéaste ne mérite ce nom que du moment où il sait qu'il fait" (Aumont, 2011). En ese sentido, el término "cine" puede ser anclado en un saber, una decisión o una puesta en marcha de un proyecto cinematográfico lo que abre un espacio amplio desde el punto de vista creativo. Igualmente, no descuidamos las importantes raíces históricas del término "video indígena" en el contexto latinoamericano. 
2008; Wortham, 2004 y 2013; Salazar, 2009; Schiwy, 2009; Córdova, 2011; De Cavalho et al., 2013; Soler, 2017; Zamorano Villareal, 2009).

Me interesa analizar aquí la experiencia de la realización cinematográfica como proceso en el que las concepciones sobre el cine y el quehacer antropológico se desplazan y transforman. Este análisis busca dejar de lado una noción de cine sobre los otros, o realizado por los otros, para pensar el espacio del audiovisual como un medio de interacción social y política, intercultural.

\section{Media-médium}

Buena parte de los antropólogos han logrado liberarse de una forma hiperdescriptiva de realizar etnografía, que proponía reforzar el distanciamiento entre el investigador y el investigado, y en la que la cámara, en la búsqueda de una objetividad cientificista, servía para profundizar ese distanciamiento. Una de las figuras claves en esa ruptura fue el antropólogo y cineasta Jean Rouch, quien mostró total libertad en sus filmes; "manipulaba las secuencias para crear no un filme de investigación, sino una verdadera obra cinematográfica; sabía hacer uso del trance que el propio filmar provocaba" (Boudreault-Fournier et al., 2016, pp. 38-39; la traducción es propia). En su clásico filme Les Maîtres Fous (1955), la cámara parece entrar en trance y disolver las distancias entre quien la opera y quienes son filmados, y permite -cámara-medium-que ingresen en escena también los espíritus, vivos y muertos. A partir de esta idea y de esta gravitación de imágenes concebí el título de este artículo, Media-médium, con el que busco indagar sobre el cine y las diferentes dimensiones de lo social que entrelaza, no enfocándome en la cámara y su operador, sino en el proceso mayor de abordar un proyecto comunitario catalizado por la realización cinematográfica.

A través del relato de una serie de experiencias vividas durante mi trabajo de campo etnográfico, sugiero posibles vías de exploración de las dimensiones del cine como experiencia, más allá de la materialidad de la obra producida. Estas dimensiones de lo social que surgen en el quehacer cinematográfico tienen que ver con cómo se construyen los vínculos al interior de cada comunidad con la que se trabaja, las relaciones entre grupos de edad y los roles de autoridad que se manifiestan y que habilitan o no la posibilidad de la realización audiovisual. Esto será ejemplificado a través de dos 
experiencias distintas, de las que se narran los momentos de la singular concepción de los guiones y del rodaje. Por otro lado, se plantea que más allá del corte final de una película, el filme puede concebirse como abierto o inacabado, en constante proceso de construcción, como una obra que se transfigura y deviene performance en una proyección, y que implica la puesta en acto de sensibilidades, decisiones estéticas e imaginarios. En este sentido, el cine como proceso en construcción, más allá de su materialidad o corte final, puede ser analizado como médium, por su capacidad de hacer entrar en contacto múltiples dimensiones de lo social y múltiples seres.

Desde 2014 he trabajado dando talleres de cine en comunidades indígenas, primero con shuar de la Amazonía ecuatoriana y, luego -desde 2015-, con indígenas del Chaco argentino, principalmente qom (tobas). He enseñado cine sola y en equipo, colaboré en rodajes comunitarios y pasé largo tiempo editando en el terreno, codo a codo con quienes se acercaban a aportar sus ideas. De a ratos ocupaba el rol de etnógrafa, tomaba notas de campo y entrevistaba a la gente sobre la experiencia de filmar y sobre los tantos otros asuntos que nos interpelaban, y luego volvía a ser un peón más en el juego del rodaje y a sostener, por ejemplo, una caña de sonido durante horas.

Generalmente, un proyecto audiovisual se aborda a partir de un guion o idea inicial; luego se pone en marcha la preproducción, se procura financiamiento y se conforma un equipo técnico, y, a continuación, se emprende la ejecución del rodaje, el montaje y la posproducción de imagen y sonido. Cuando se trata de cine comunitario e indígena, este procedimiento difícilmente tenga una forma predecible ni se dé en ese orden. El antropólogo-cineasta que se acerca al cine comunitario tiene que desaprender continuamente su manera de trabajar si pretende abrirse paso, a través de la realización cinematográfica, hacia el conocimiento, íntimo y singular, de otras maneras de vincularse. Esto implica una doble tarea: la de alejarse de las maneras aprendidas de hacer cine, y la de aprender nuevos códigos sociales y narrativos.

\section{La construcción de un guion comunitario}

Mi experiencia de cine comunitario entre los shuar tuvo lugar en el Centro Kupiamais, en la Cordillera del Cóndor (Amazonía ecuatoriana) en el 
marco del proyecto Etsa-Nantu/Cámara-Shuar ${ }^{5}$. Este proyecto, coordinado por Verenice Benítez y Domingo Ankuash surgió a pedido de algunos referentes de la comunidad, quienes buscaban aprender a usar las cámaras con el fin de denunciar los abusos de las empresas extractivitas mineras y del Gobierno ecuatoriano, que violentaban a las poblaciones amazónicas de la región. A fines de mayo de 2014 llegamos allí con Verenice para dar un segundo taller de cine, tras una primera experiencia llevada a cabo en febrero de ese mismo año, en la que yo no había participado. Luego de varios días de incertidumbre y discusiones internas respecto al cine y nuestro rol en la comunidad, logramos comenzar. Los primeros días del taller, tras habernos explayado sobre el uso de la cámara y habiendo presentado un amplio abanico de géneros y estilos cinematográficos, propusimos a los alumnos que trajeran historias para realizar un primer cortometraje. Lo sorprendente fue que, al día siguiente, nadie planteó la realización de un documental sobre la difícil situación que estaban viviendo, sino que todas las historias eran relatos sobre seres no-humanos; algunos, largos y complejos; otros, tan simples como la aparición de iwianch (ser no-humano que los shuar traducen como diablo al idioma castellano). Ese día apuntamos en nuestros cuadernos cerca de diez historias que nos forzarían a improvisar rodajes de cine de ficción ${ }^{6}$ en la selva, en el marco mayor de un conflicto minero que nos convocaba y movilizaba.

El primer trabajo fue un cortometraje de 7 minutos, titulado precisamente Iwianch $^{7}$, que narra la visita inesperada de un iwianch a la casa de una mujer viuda que vivía sola con sus hijos. En esta primera experiencia, la escritura del guion narrativo fue simple, y los únicos implicados en la tarea audiovisual fueron jóvenes y adultos jóvenes, que narraron las historias tradicionales sin confrontar versiones. Patrico Taish, un líder local, nos prestó su vivienda típica shuar para el rodaje y, a partir de allí, comenzó a implicarse en lo que estábamos haciendo. Tras lograr montar un primer corte comenzamos a entender qué tipo de filme podíamos lograr.

5 Para más información sobre este proyecto se puede visitar el sitio www.camara-shuar.org

6 Aquí es importante remarcar que la distinción entre ficción y realidad es una invención del mundo occidental, como proponen Boudreault-Fournier et al. (2016): "Esta oposición no existe en el mundo amerindio, donde los sueños, o los trances de los shamanes no se caracterizan como una no realidad" (p. 39). En este sentido, cuando hablo de ficción, hago referencia al tipo de abordaje cinematográfico que caracteriza la escritura, planificación y rodaje de este género audiovisual.

7 Filme disponible en: https://vimeo.com/102850114 
Los participantes del taller nos propusieron continuar con la historia de Tsunki, que narra los orígenes de su pueblo. Durante la tarde, y hasta avanzada la noche, conseguimos escribir un primer guion narrativo, y en pocos días nos lanzarnos a un nuevo rodaje. Al final de una de las últimas jornadas de filmación lo visitamos a Patricio, quien grabaría la voz en off. Nos sentamos al lado del fuego con Rosa, su esposa, y leí en voz alta y sin interrupciones el guion ante su escucha atenta. Cuando terminé la narración, Patricio me miró fijo y me dijo: “¿Quién te contó esta historia? Esto no es asî”. Nos relató su versión y nos habló de una viejita de más de 90 años de edad que seguramente conocería otra versión mejor todavía. Ahí nos dimos cuenta de que la distancia inicial que los adultos habían mostrado hacia el aprendizaje del cine nos había hecho descuidar su autoridad como narradores y portadores de la historia (de transmisión oral), y que las versiones de las historias serían siempre múltiples, pero aquella que debería quedar plasmada en una película tenía que ser la de la voz de alguien con la sabiduría y la autoridad para narrarla. Luego de tres semanas de trabajo, la película tuvo que quedar inconclusa.

En octubre de ese mismo año volví a Kupiamais para continuar con los talleres, esta vez con Franco Passarelli. Él me acompañó los primeros días, durante los cuales retomamos la escritura del guion. Esta vez Patricio Taish ya estaba completamente implicado en la tarea audiovisual y nos propuso varios cambios en la forma de trabajar. Pensaba que los actores con los que habíamos rodado los primeros planos de Tsunki eran muy jóvenes y no comprendían la importancia del relato; no conocían a los seres que tenían que encarnar. Entonces nos propuso invitar a otras personas y, tratando de sanar un conflicto comunitario que se había abierto -se habían generado sospechas de que el proyecto de cine podía favorecer a una facción de la comunidad y no a otra-,${ }^{8}$ incorporamos gente de otras familias. Finalmente, la abuela de 90 años nos hizo llegar su versión a través de su nieto; ésta no era la más completa que escuchamos y difería bastante de las otras, pero nadie sugirió modificarla en ningún sentido, así que se realizó el rodaje a partir de ella. A través de este recorrido pudimos construir comunitariamente un guion definitivo para realizar el cortometraje Tsunki Aumatsamu (El mito de Tsunki) .

8 Los shuar tejen sus vínculos históricamente a través de alianzas y enemistades. Comenzar a trabajar con los shuar implica que esas rupturas se manifiesten en torno a las nuevas iniciativas. Patricio, sin decírnoslo, acercó al proyecto de cine a personas que sospechaban que éste iba a beneficiar a unas familias en desmedro de otras, y así buscó pacificar los conflictos.

9 Filme disponible en: https://vimeo.com/157352441 


\section{Lo individual y lo colectivo. Libertad narrativa}

En enero de 2017 tuve la posibilidad de presentar avances de mi investigación doctoral en el marco del seminario Pour une anthropologie visuelle pluridisciplinaire et multimédia, organizado por Jean-Paul Colleyn ${ }^{10}$. Allí reflexioné sobre distintas experiencias de campo en torno al cine comunitario indígena, entre ellas, la experiencia con los jóvenes de la comunidad qom Paraje Maipú, en el Chaco argentino. Al finalizar la intervención, una señora del auditorio se acercó y me hizo dos comentarios sobre el filme qom que había proyectado: el primero, acerca de la dicha que veía en los protagonistas -ella consideraba que era algo que faltaba en la sociedad francesa-; el segundo, más distante y tajante, fue: "ça, pour nous, c'est bidonville" (para nosotros esto es de un barrio marginal), de lo que interpreté que ella no veía los rasgos de indigeneidad que esperaba encontrar en el cine de esos jóvenes. Con mi manejo del francés algo limitado y la certeza de que no me correspondía justificar las elecciones estéticas de los chicos de Maipú, mostré sincero asombro ante su comentario y le agradecí la intervención, sin lograr comprender qué era lo que ella esperaba de ese filme para poder catalogarlo como "indígena". Ese comentario me quedó resonando y, por un lado, me sirvió para pensar las limitaciones de una película, como producto terminado, para mostrar sus condiciones de realización; por otro, me llevó a reflexionar sobre el aprendizaje adquirido durante mi experiencia de campo, que me permitía comprender algunos vínculos sociales y agenciamientos, característicos de las comunidades qom de esa región, que se habían puesto en juego para que esa película fuera posible.

Los jóvenes de Maipú crearon su propia forma de narrar y esa forma nada tiene que ver con indagar en el devenir histórico de su comunidad o en su condición de indígenas; eso no es algo que los interpele o sobre lo que quieran reflexionar en sus videos. En un comienzo nos propusieron hacer un remake de un videoclip de una banda de k-pop (música pop de Corea del Sur) que ellos escuchan, pero luego transformaron esa idea y la hibridaron con una narrativa propia. El proceso de guionado fue muy diferente al de los shuar (se puede

10 Jean-Paul Colleyn fue mi director durante la maestría que realicé en la École Des Hautes Études en Sciences Sociales (EHESS, 2013), y sigue guiando mis estudios de doctorado desde entonces. La intervención tuvo lugar en la EHESS, París, el día 19 de enero de 2016, y se tituló: Cinéma amérindien: Une analyse à partir des expériences des peuples Shuar (Amazonie équatorienne) et Qom (Chaco argentin). 
decir que, entre los qom, la confrontación no forma parte de su manera vincularse), y los adultos no participaron. En los primeros encuentros notamos que los jóvenes se sentían intimidados cada vez que les pedíamos que hicieran propuestas, por lo que fue necesario encontrar referentes al interior del grupo que bocetaran los guiones en sus casas; luego, durante el rodaje, se irían transformando con los aportes de todo el equipo. En Maipú trabajé junto con Eugenia Mora, y aprendimos que nuestra presencia como adultas y rokshe (blancas o "criollas") imponía una distancia que era muy difícil de soslayar, y que para que los jóvenes pudieran tener la libertad de narrar lo que quisieran, era necesaria esa distancia respetuosa; ellos mismos se acercarían a nosotras en la medida que necesitaran consejos. Aprendimos también que de esa manera se construyen los vínculos en las comunidades qom: los adultos y ancianos observan a los jóvenes, pero no imponen ni regulan conductas; están allí, en un segundo plano, para aconsejar.

El cortometraje que realizaron los jóvenes de Paraje Maipú se llama El sueño y es una ficción que narra el recorrido de Ramiro, un muchacho que se despierta solo en una cama, enciende el televisor y se ve a sí mismo bailando junto con sus hermanos y sus primos. Movilizado por la nostalgia, bajo el sopor del verano chaqueño, decide ir a buscar a sus amigos y los encuentra realizando actividades de su vida cotidiana.

La escritura del guion fue cobrando forma colectiva, ya que Romina, quien había preparado un primer boceto de la historia, propuso un esquema flexible para que cada quien, al momento de decidir cómo aparecería frente a la cámara, lo fuera modelando y modificando. Por ejemplo, Lía es una de las chicas más grandes del grupo y se caracteriza por su timidez; ella no baila, sino que participa buscando nuevos videos y descubriendo coreografías. Es experta en cestería qom, y Romina pensó que Ramiro la podría encontrar fabricando cestos. Filmaron unos hermosos planos en los que ella salía sentada, con su pelo suelto, trabajando. A mi parecer, ese personaje ofrecía al filme un interesante contrapunto, ya que no se habían elegido otras actividades que hicieran referencia a costumbres u oficios típicamente indígenas. Lamentablemente, Lía manifestó que no le gustaban esas imágenes, y sus compañeros -lejos de querer convencerla de seguir en esa línea- la ayudaron a planificar otras escenas. Todas estas modificaciones sobre la marcha fueron tomadas con total naturalidad por Romina, que apuntaba los cambios en su cuaderno, sin preocuparse por defender una posición de autora. 
La historia del cortometraje tiene un desenlace enigmático: una vez que todos los jóvenes se reúnen en torno a una fogata, Ramiro le muestra a una compañera una foto del grupo y se pregunta: “¿Será que volveremos a bailar?". La escena siguiente es un plano picado que gira sobre su eje y muestra a todos los personajes durmiendo. A medida que se van despertando, van saliendo, corriendo, por una puerta. Un tema de k-pop comienza a sonar y todos van hacia el atardecer en un plano a contraluz; corren alegres, celebrando el estar juntos.

Volviendo a la pregunta de la asistente al seminario, una respuesta posible a su interrogante estaría en cómo este filme fue realizado: su planificación y su edición final se llevaron a cabo en un ambiente de apertura a las propuestas y a los consejos mutuos, característico de los qom de esa región, lo que derivó en una forma singular de trabajo. Pero la respuesta podría ser mucho más amplia y compleja si hacemos referencia a que las comunidades que viven en esa zona se asentaron allí en tiempos en que funcionaba el ingenio azucarero Las Palmas del Chaco Austral ${ }^{11}$. Las poblaciones indígenas de la región, que venían siendo desplazadas por las avanzadas militares de la llamada Conquista del Desierto ${ }^{12}$, pasaron a ser la mano de obra barata en la explotación de la caña de azúcar, y dividieron su tiempo entre la zafra estacional y la caza y la recolección que practicaban en el monte, que aún no se había talado para la explotación agrícola. Cuando en los años 1970 el ingenio comenzó su largo proceso de quiebra, las familias que trabajan en una estancia denominada Las Coloradas empezaron a ser perseguidas violentamente. Sus viviendas fueron destruidas y sus huertos arados; se les prohibió cazar y pescar en el monte, lo que los llevó a una gran crisis y a una terrible hambruna. En ese marco surgió la figura de un líder llamado Mateo Quintana. Quintana se hizo al evangelismo y empezó a predicar y a tener visiones sobre un futuro mejor; comenzó

11 El ingenio fue fundado por los hermanos Richard y Charles Hardy en 1882. Estos colonos, como concesión del Gobierno nacional, obtuvieron 100000 hectáreas de territorios en los que habitaban comunidades indígenas.

12 A diferencia de lo que ocurrió en la mayor parte de los países latinoamericanos, Argentina se construyó como Estado nación a partir de un discurso de borramiento de los indígenas; hubo una operación de tachado, de negación. Como afirma Miguel Bartolomé (2003), "el mito de un inmenso territorio ‘desierto' y sólo transitado por unas cuantas hordas de cazadores 'bárbaros' ha sido particularmente grato a la historiografía argentina, en tanto fundamentaba el modelo europeizante bajo el cual se organizó el proceso de construcción nacional". (Ver también Briones, 2004; Lenton, 2005; Ramos, 2009). 
a tener sueños sobre nuevas tierras donde se instalarían y conseguirían bienes característicos de los hombres blancos. Los que siguieron las visiones de este líder se instalaron en Paraje Maipú, que para ellos es la tierra prometida. El tiempo presente es el tiempo de la concreción de las predicciones de Quintana, las que se siguen materializando. Quintana visionó que tendrían una escuela, luz, agua; llegaría gente que hablaría otras lenguas, llegaría gente que les enseñaría nuevas tecnologías. Según nos explicaron los adultos, ellos entienden que nuestro trabajo forma parte de esas predicciones, y que los jóvenes son una generación capaz de aprender nuevos saberes y de abrirse al mundo de los blancos. Los adultos han pasado por el sufrimiento del trabajo forzado en la zafra, de la persecución militar, de la incertidumbre constante, y ven en los jóvenes la concreción de la promesa de una vida nueva, en un sentido material y espiritual. Que los jóvenes de Maipú nos convoquen para aprender a filmar, y que filmen sin ninguna imposición con respecto a qué historias son las que deben narrarse, o a las historias que narraríamos los antropólogos, es algo que guarda estrecha relación con cómo esa comunidad entiende su devenir histórico y vive su vida comunitaria.

\section{La película incompleta}

Algunas historias narradas a través de este cine ingresan en una dinámica que les quita el estatus de obra acabada. Cuando terminamos de rodar Tsunki Aumatsamu, pasé varios días en la comunidad para intentar editar un primer corte en el terreno y para discutir con la gente sobre qué forma le daríamos al filme. Fueron días de fiebre y de problemas de salud tras el cansancio del rodaje. Varias personas iban a visitarme a la casa de los Ankuash, donde me hospedaba, y me ofrecían comida y medicamentos; yo les mostraba los avances de la edición. Un día de lluvia, un familiar vecino se sentó en la galería a conversar con las mujeres de la casa. Las charlas en lengua shuar me mantuvieron un poco al margen hasta que alguien me explicó que hablaban sobre la historia de Tsunki. Como a la película aún le faltaba mucho trabajo para ser mostrada, este señor me pidió que le contara lo que habíamos filmado. Narré la versión tal cual la habíamos guionado, esperando una respuesta que aportara alguna nueva idea para el montaje. Cuando terminé, el hombre hizo un silencio y largó una larga car- 
cajada. Me dijo: “¿Quién contó esa historia?; tengo una abuela que me la explicó de otra manera”. Entre el cansancio y la fiebre recuerdo este episodio más como una pesadilla que como una anécdota divertida. Por la tarde vinieron Rosa y Patricio a verme y a ofrecerme una chicha curativa. Les conté lo que había pasado y Patricio me dijo de manera muy calma: "Sería bueno conocer la historia contada por esta otra abuela". En ese momento me di cuenta de que la película nunca estaría acabada, en la medida en que seguiría imbricándose con otros relatos orales e imágenes sobre el relato. Siempre habría nuevas versiones para narrar, nuevas interpretaciones y nuevas formas de concebir a los personajes -seres no-humanos corporizados por actores-. Las nuevas versiones posibles de la historia nos hicieron repensar las elipsis de la película y los espacios en los que lo narrado con la imagen sería reemplazado por la voz en off de Patricio, que atravesaría todo el filme. Registrar esas imágenes en movimiento, grabar esas voces y esos sonidos y darles un orden, un tono y una cadencia impulsaron nuevas dinámicas que aportaron otros sentidos a los relatos orales.

Quizá, a partir de esta película, los shuar de Kupiamais comiencen a concebir a Tsunki con otro aspecto, a otorgar al Tsunki padre la mirada noble de Patricio Taish, con su sonrisa siempre delineada. Tal vez estas imágenes puedan abrir el campo a nuevas historias, narradas por los que estén y con los que ya se fueron. Imagen y sonido se articulan. El sonido, siguiendo a Ong (2006), "da acceso a la interioridad de algo sin violarlo", y posee un carácter "armonizador" por oposición al carácter "discriminador" de la vista. "La vista aísla; el oído une. Mientras la vista sitúa al observador fuera de lo que está mirando, a distancia, el sonido envuelve al oyente" (Ong, 2006, p. 75). Estos dos elementos se articulan al interior del filme y se dinamizan con la oralidad pura que dispara imágenes en la interioridad de la gente. La imagen audiovisual tiene esa capacidad de maravillarnos, de afectarnos, de movilizar procesos de identificación con la imagen.

Cuando con Eugenia Mora comenzamos a dar clases de cine a algunos adultos en Paraje Maipú, mostramos un cortometraje paraguayo denominado Karaí norte, a fin de explicar los distintos tipos de planos y el raccord que se establece en el montaje. Al terminar la proyección y encender la luz, una de las señoras asistentes nos miró con un gesto asustado y nos dijo: "Ese hombre en la película era Nowet, el dueño del monte" (Cordeu, 
1969-1970). Las imágenes del cine se asocian a los imaginarios de los espectadores. El cine comunitario fuerza los límites de los cuatro vértices del rectángulo de la pantalla. Cuando en 2011 se estrenó La nación ocul$t a$, reconocida como la primera película de ficción producida por indígenas chaqueños ${ }^{13}$, se realizó una celebración en la que participaron pueblos indígenas de distintas regiones; hubo ceremonias rituales y se homenajeó a los actores y a los realizadores. La materialidad de filme, sus aciertos o problemas, quedaron al margen durante el emotivo acto -en el que hubo lágrimas y cantos-. La película se completó en esa ceremonia performática de la que ahora, para quienes la vivimos, es indisociable.

\section{Reflexiones finales}

Antropología compartida, proponía Rouch. Hoy, muchos realizamos cine compartido y, desde allí, repensamos la antropología y el cine, en ese quehacer en el que los roles autorales y el orden de los procedimientos se desdibujan para ser reinventados en el marco de nuevas prácticas cinematográficas. Con este recorrido sobre algunas experiencias en torno a la realización cinematográfica indígena, mi intención fue la de abrir un espacio de reflexión para abordar el cine en el marco social en el que se gesta; la apropiación de los medios por los pueblos indígenas de Latinoamérica expande la reflexión en torno al audiovisual. Faye Ginsburg propone que los medios indígenas, junto con el cine etnográfico, "intentan comunicar algo sobre esta identidad social o colectiva que llamamos 'cultura', a fin de mediar (eso se espera) a través de las brechas de espacio, tiempo, conocimiento y prejuicio" (1991, p. 104; la traducción es propia). La cualidad de la etnografía como experiencia sensible de acompañamiento nos permite dejarnos atravesar por otras maneras de habitar este mundo, y nos ofrece, desde allí, otras dimensiones de lo cinematográfico.

Asimismo, con este recorrido busqué visibilizar algunas cuestiones de este mundo globalizado que interpelan a los indígenas. Entre los shuar, la elección de no realizar un cine de lo inmediato -de denuncia- sino de lo remoto, nos lleva a reflexionar sobre la urgencia de plasmar esas historias

13 Esta película es el producto de una serie de talleres que desde 2008 dictó el Centro de Formación y Realización Cinematográfica de Bolivia (CEFREC) en el marco de los festivales de cine indígena que se organizaron desde la Dirección de Cine de la provincia de Chaco (ver Soler, 2017). 
tradicionales, no al modo de un cine de rescate, sino como una respuesta al avance de los intereses del proyecto moderno, que busca borrar las singularidades de las poblaciones y desterrar a todos aquellos que no alimenten un sistema económico predatorio. Tal vez las ficciones shuar operen como una nueva vía para transmitir estas historias y seguir reinventándolas. Por otro lado, acompañar procesos de aprendizaje de cine en comunidades indígenas implicó para mi dejar de lado los prejuicios colonialistas de qué es lo que los "otros" deberían filmar y cómo deberían hacerlo. La libertad narrativa de los jóvenes qom de Paraje Maipú permitió que registraran todo lo que un etnógrafo jamás filmaría en el campo; ellos recortan su entorno, su vínculo con los adultos, su forma de habitar el espacio, e hibridan sus hábitos y paisajes con estéticas del globalizado k-pop. Esta libertad se construye desde un ethos $^{14}$ indígena de la no imposición.

\section{Bibliografía}

Bartolomé, M. (2003). Los pobladores del "Desierto" genocidio, etnocidio y etnogénesis en la Argentina. Cuadernos de Antropología Social FFyL-UBA, $17,162-189$.

Bateson, G. (1958). Naven, a survey of the problems suggested by a composite picture of the culture of a New Guinea tribe drawn from three points of view. Stanford, California: Stanford University Press.

Bateson, G., \& Mead, M. (1942). Balinese character, a photographic analysis,. New York: The New York academy of sciences.

Boudreault-Fournier, A., Satiko Gitirana Hikiji, R., \& Caiuby Novaes, S. (2016). Etnofiçao: uma ponte entre fronteiras. En A experiência da imagem na etnografia (pp. 37-58). São Paulo: Terceiro Nome.

14 Gregory Bateson, en su obra Naven ([1936] 1958), introdujo el término griego ethos por primera vez en la antropología. El sentido aristotélico se refiere al tono predominante de los sentimientos de las personas en una comunidad. Bateson utiliza este término para hacer frente a lo que llamó "configuraciones" culturales, y lo asocia con su complementaria eidos. Geertz (1957), en una línea similar, y teniendo en cuenta su complementaria wordwide, retoma el término ethos haciendo referencia al tono, el carácter y la calidad de su vida, su estilo moral y estético y la disposición de su ánimo. Se trata de la actitud subyacente que un pueblo tiene ante sí mismo y ante el mundo que la vida refleja (Geertz, 1957). 
Briones, C. (2004). Construcciones de aboriginalidad en Argentina. Société Suisse Des Américanistes / Schweizerische Amerikanisten-Gesellschaft, (Bulletin 68), 73-90.

Colleyn, J.-P. (2004). Jean Rouch, presque un homme-siècle. L Homme, (171-172), 537-541. https://doi.org/10.4000/lhomme.25007

Cordeu, E. J. (1969). Aproximación al horizonte mítico de los tobas. Runa, XII partes 1-2, 67-173.

Córdova, A. (2011). Estéticas enraizadas: aproximaciones al video indígena en América Latina. Comunicación Y Medios. Universidad de Chile, 24, 81-107.

De Carvalho, A., De Carvalho, E. I. de, \& Carelli, V. (2011). Vídeo nas aldeias, 25 anos: 1986 - 2011. (Video nas Aldeias (Project), Ed.). Olinda, PE, Brasil: Vídeo nas Aldeias.

Ginsburg, F. (1991). Indigenous Media: Faustian Contract or Global Village? Cultural Anthropology, 6(1), 92-112.

Lenton, D. (2005). De centauros a protegidos. La construcción del sujeto de la política indigenista argentina desde los debates parlamentarios (1880 1970). Universidad de Buenos Aires, Buenos Aires.

Mead, M. (2003). Visual Anthropology in a Discipline of Words. En P. Hockings (Ed.), Principles of Visual Anthropology (2nd ed.). Berlin ; New York: Mouton de Gruyter.

Nichols, B. (1997). La representación de la realidad: cuestiones y conceptos sobre el documental. (J. Cerdán \& E. Iriarte, Trans.). Barcelona: Paidós.

Ong, W. J. (2006). Oralidad y escritura: tecnologías de la palabra (1. ed). México, D.F: Fondo de Cultura Económica.

Piault, M. H. (2000). Anthropologie et cinéma: passage à l'image, passage par l'image. Paris: Nathan.

Ramos, A. R. (2009). O indigenismo na montagem da naçao. Contrastes e converências entre Brasil e Argentina. Anuario Antropológico/2007-2008, 27-59.

Rony, F. T. (1996). The third eye: race, cinema, and ethnographic spectacle. Durham, NC: Duke University Press.

Rouch, J. (1955). Les maîtres fous.

Ruby, J. (1991). Speaking For, Speaking About, Speaking With, or Speaking Alongside An Anthropological and Documentary Dilemma. Visual Anthropology Review, 7(2), 50-67. https://doi.org/10.1525/var.1991.7.2.50

Ruby, J. (2000). Picturing culture: explorations of film \& anthropology. Chicago: University of Chicago Press. 
Salazar, J. F., \& Córdova, A. (2008). Imperfect media and the politics of the poetics of Indigenos Video in Latin America. En P. Wilson \& M. Stewart (Eds.), Global indigenous media: cultures, poetics, and politics. Durham: Duke University Press.

Schiwy, F. (2009). Indianizing film: decolonization, the Andes, and the question of technology. New Brunswick, N.J: Rutgers University Press.

Soler, C. (2017). Enfocar nuestra trinchera. El surgimiento del cine indígena en la provincia de Chaco (Argentina). Folia Histórica Del Nordeste, 28, 71-97.

Worth, S., \& Adair, J. (1970). Navajo Filmmakers. American Anthropologist, 72(1), 9-34.

Worth, S., \& Adair, J. (1972). Through Navajo eyes; an exploration in film communication and anthropology. Bloomington: Indiana University Press.

Wortham, E. C. (2004). Between the State and Indigenous Autonomy: Unpacking Video Indígena in Mexico. American Anthropologist, 106(2), 363-368. https://doi.org/10.1525/aa.2004.106.2.363

Wortham, E. C. (2013). Indigenous Media in Mexico: Culture, Community, and the State. Londres: Duke University Press.

Zamorano Villarreal, G. (2009). Reimagining Politics: Video and Indigenous Struggles in Contemporary Bolivia. New York University, New York.

\section{Filmografía}

Pueblo shuar (2014). Iwianch [HD]. Etsa-Nantu/Cámara-Shuar. Disponible en: https://vimeo.com/102850114

Pueblo shuar (2015). Tsunki aumatsamu, el mito de Tsunki [HD]. Disponible en: https://vimeo.com/157352441

Fecha de recepción: 19/06/2017; fecha de aceptación: 31/07/2017;

fecha de publicación: 01/09/2017 


\title{
La imagen en disputa. Cronistas barriales. Producir desde los barrios
}

\author{
The image in dispute. Cronistas Barriales. \\ Produce from the neighborhoods
}

\author{
Néstor Daniel González ${ }^{1}$ \\ nestordanielgonzalez@gmail.com \\ ngonzalez@unq.edu.ar \\ Cecilia Elizondo ${ }^{2}$ \\ elizondocecilia@hotmail.com \\ Juan García ${ }^{3}$ \\ juan.a.gar@hotmail.com
}

\section{Resumen}

El proyecto de extensión "Cronistas Barriales" de la Universidad Nacional de Quilmes tiene como objetivo capacitar a jóvenes de distintos barrios de la región en lenguaje, producción y posproducción informativa audiovisual, con el fin de desarrollar un noticiero interbarrial realizado por jóvenes de la periferia del área metropolitana de Buenos Aires.

Las temáticas del noticiero se proponen de acuerdo a las necesidades informativas de la cotidianidad territorial en la cual se inserta el proyecto, posicionando a los y las jóvenes participantes en un rol activo y crítico frente a la realidad comunicacional.

El objetivo de este trabajo es describir el proyecto en sus etapas y alcances, analizando a su vez la experiencia desde la dimensión pedagógica, política y comunicacional.

\section{Palabras clave}

Información audiovisual, comunicación popular, educación, política pública.

Forma sugerida de citar: González, Néstor Daniel, Elizondo, Cecilia, \& García, Juan (2017). La imagen en disputa. Cronistas barriales. Producir desde los barrios. Universitas, $X V(27)$, pp. 195-209.

1 Vicedirector del Departamento de Ciencias Sociales de la Universidad Nacional de Quilmes. Magister en Periodismo y Medios de Comunicación (UNLP). Profesor e Investigador de la Universidad Nacional de Quilmes y la Universidad Nacional de La Plata. Director del Proyecto de Extensión universitaria Cronistas Barriales. Orcid: 0000-0002-0671-8561.

2 Directora de la Licenciatura en Educación (Modalidad a Distancia) Universidad Nacional de Quilmes. Licenciada en Educación (UNQ) Comunicadora Audiovisual (UNLP). Profesora e Investigadora de la Universidad Nacional de Quilmes. Codirectora del Proyecto de Extensión Universitaria Cronistas Barriales. Orcid: 0000-0001-5954-7121

3 Especialista en Planificación y Gestión de Políticas Sociales. Universidad de Buenos Aires. Profesor en Comunicación Social por la Universidad Nacional de La Plata. Coordinador Ejecutivo del Proyecto de Extensión Universitaria Cronistas Barriales. Orcid: 0000-0002-1535-9126. 


\begin{abstract}
Cronistas Barriales is a Project produced by Quilmes National University (UNQUI) in Buenos Aires, Argentina. Its main goal is to prepare teenagers, from different neighborhoods in the areas of audiovisual languages, broadcasting and production to be able to develop a news programme based on their socio-economic realities and vulnerabilities. It is necessary to clarify that the project is developed in deprived areas in Buenos Aires.

The topics of the news are proposed according to the informational needs of the territorial daily life in which the project is inserted, positioning the young participants in an active and critical role in the face of communicational reality.

The objective of this work is to describe the project in its stages and scope, analyzing in turn the experience from the pedagogical, political and communicational dimension.
\end{abstract}

\title{
Keywords
}

Audiovisual information, popular communication, education, public policy.

Los procesos de transformación vividos en América Latina en los últimos años mediante la presencia de gobiernos populares, incluyeron en la agenda pública el debate de la comunicación social, poniéndola en visibilidad como un derecho humano inalienable, generando nuevas legislaciones que buscaron poner límites a la concentración de los medios y promoviendo condiciones para un sistema de distribución más equitativo y democrático de la palabra. Ese fue el caso de países como Bolivia, Ecuador, Uruguay y Argentina, entre otros.

Las políticas en comunicación audiovisual en Argentina pusieron en visibilidad reflexiones en torno al rol de la imagen en nuestra sociedad. En particular, la información televisiva, que cada vez más tildada de ser un producto de consumo y al servicio de los intereses económicos de las empresas que producen la información.

En este sentido es preciso advertir que por un lado, la democratización de la información requiere, entre otras cosas, trasladar su producción a aquellos lugares donde la información es considerada un derecho humano y está al servicio de necesidades sociales. Por otro lado, la aparición de procesos 
de alfabetización audiovisual en la marco del sistema educativo oficial tuvo que esperar hasta la aprobación de la Ley Nacional Educativa vigente hacia finales de 2006, que comenzó a enfrentar algunas de las tradicionales tensiones manifiestas entre la escuela y las cultural populares, entre ellas, la televisión.

En el marco del programa de extensión universitaria "Comunicación, Participación y Ciudadanía" de la Universidad Nacional de Quilmes, el proyecto "Cronistas Barriales" está a cargo de la realización de un noticiero audiovisual producido por jóvenes de distintos barrios populares del área metropolitana de Buenos Aires, que busca trasladar el proceso de producción audiovisual informativo a dichos sectores de la sociedad con temáticas propuestas de acuerdo a las necesidades de la cotidianeidad territorial.

Dicho noticiero sale al aire a través de UNQ TV (http://tv.unq.edu.ar/), el canal web de la mencionada casa de altos estudios.

El proyecto, que ya lleva más de cinco años de ejecución, tiene como objetivo capacitar a jóvenes de distintos barrios de la región en lenguaje, producción y posproducción informativa audiovisual y producir un noticiero audiovisual interbarrial.

Es importante mencionar que desde su comienzo el proyecto contó con la articulación territorial del Equipo de Participación Social y del Equipo Territorial de Infancia y Adolescencia, dependientes de la Secretaría de Desarrollo Social de la Municipalidad de Quilmes.

Además, participaron los docentes, tutores y orientadores pedagógicos de los jóvenes, que forman parte de sus comunidades educativas.

Esto quiere decir que se trabaja a partir de una articulación intensa entre actores del municipio local, organizaciones sociales, Universidad y representantes de las comunidades educativas de la región: Escuela de Educación Media $N^{\circ}$ 6, Escuela de Educación Secundaria Técnica $\mathrm{N}^{\circ}$ 8, Escuela de Educación Media $\mathrm{N}^{\circ} 13$ "Libertadores de América", Escuela Primaria $\mathrm{N}^{\circ} 15$, Escuela Secundaria Básica $\mathrm{N}^{\circ} 20$, Escuela Secundaria Básica $\mathrm{N}^{\circ} 36$, Escuela Primaria $N^{\circ} 48$ y la Escuela de Educación Especial $N^{\circ} 502$ Padre Carlos Cajade, de Berisso. Y las organizaciones sociales participantes, integrantes de las "Mesas Participativas de Gestión Barrial" de la Secretaría de Desarrollo Social de Quilmes, y la Jefatura Distrital de Quilmes, entre las que se destacan Zapatillas Gastadas (Ezpeleta), El Hogar de mis sueños (IAPI), Centro de día Nuestra esperanza grande (Eucalipto de Solano), Parroquia la Asunción del Señor (Villa Luján), Casa del Niño de Quilmes, Vi- 
lla Valdocco (El monte y El matadero), Centro San Pedro y San Pablo, (San Sebastián 1) La casita de la cava (Villa Itatí), La Casa del Niño Medalla Milagrosa (San Francisco Solano), Colectivo de a pie, entre otras.

En síntesis, Cronistas Barriales es un proyecto concebido como un instrumento de intervención social desde las herramientas de la comunicación social, la educación y la política pública.

A su vez, es importante destacar, que la extensión universitaria afronta hoy nuevos retos, ya que los procesos culturales, sociales, económicos, ambientales, productivos y tecnológicos ponen en tensión los paradigmas tradicionales de formación académica y de investigación científica que el sistema universitario desarrolla. La Universidad de Quilmes prioriza en sus acciones sustantivas la extensión, entendida como la vinculación mediante la cual la Universidad pone a disposición de la sociedad sus logros en docencia e investigación y a la vez, enriquece y retroalimenta su práctica académica, al tomar contacto con la problemática y perspectiva del medio social en el que se inserta. En este sentido, la Universidad Nacional de Quilmes cuenta con un Programa de Extensión del Área de Comunicación y el Proyecto que aquí se describe permite profundizar los lazos de la Universidad con el medio a través del contacto con organizaciones sociales que valoran el rol multidimensional de la comunicación en los procesos de desarrollo local.

De este modo, la iniciativa aporta a la construcción del diálogo entre saberes, a la generación y apropiación de contenidos, a la circulación de relatos, prácticas culturales y productivas, a la construcción de sentido, a la creación de nuevas redes. El conjunto de conocimientos humanísticos, científicos y tecnológicos no deben conformar una reserva cristalizada o depositada en las fronteras académicas, sino que tiene que constituirse en una masa crítica disponible al servicio de la transformación social.

\section{La información y los barrios}

La mayoría de los y las jóvenes que participan en este proyecto viven y transcurren su escolaridad en distritos populares. Estas zonas suelen ser estigmatizadas por los medios masivos, y son señalados como sectores en los cuales reinan la violencia y la inseguridad (Saintout, 2013). Cuando los y las jóvenes ven, oyen y leen noticias sobre áreas que comparten las ca- 
racterísticas de sus barrios, reciben en la inmensa mayoría de los casos lo que calificamos como malas noticias o informaciones con ejes de conflictividad. Y en particular, esas características informativas se acentúan cuando el tratamiento es sobre las juventudes. Es decir, se estigmatiza a dichos grupos tanto sociales como etáreos, atribuyéndoles una identidad, basada en un contexto de riesgo, atribuyéndoles la etiqueta de "Jóvenes peligrosos"4.

En consecuencia, el proyecto no solo considera abordar las problemáticas de los barrios a través de la mirada de sus protagonistas, sino que también asistir a un hecho transformador como representa la producción audiovisual.

Para llevar adelante los objetivos de trabajo, el proyecto se ocupa primero de la capacitación sobre el lenguaje audiovisual, producción, registro y postproducción, y sobre criterios noticiables y elaboración de noticias audiovisuales, y luego de la realización. En la capacitación se brindan herramientas de lenguaje y estilo audiovisual, narrativas informativas audiovisuales y estrategias de preproducción y producción para la realización materiales audiovisuales comunitarios acerca de historias y problemáticas barriales, pero desde las propias visiones de quienes las viven cotidianamente. Observemos la expresión de uno de los "cronistas" que rapea elocuentemente:

...somos los comerciantes de nuestra propia cultura, acá no vamos a mostrar lo que muestran todo el día en el diario, a todo horario, dicen que la tele enseña más, más nada que ver, enseña menos, tengo mi maldita visión, todo me parece asqueroso como en la televisión...

Es pertinente mencionar que durante los encuentros de capacitación iniciales los jóvenes consideran que las noticias centradas en la violencia social eran aquellas realmente importantes, habiendo naturalizado la estigmatización de la cual ellos y todos los chicos que viven en barrios populares son víctimas.

4 Informe sobre la representación de las juventudes en programas informativos y periodísticos. Agosto de 2009. Observatorio de la Discriminación en Radio y Televisión. Autoridad Federal de Servicios de Comunicación Audiovisual. Presidencia de la Nación.

Informe: El proyecto de voto a los 16 en noticieros de TV abierta. Observatorio de Jóvenes, Comunicación y Medios. Facultad de Periodismo y Comunicación Social. Universidad Nacional de La Plata. 
Sin embargo, a medida que continuaron las reuniones y se intensificaron los procesos de producción, los jóvenes modificaron progresivamente esta idea. Como ejemplo de esto, una de las jóvenes conductoras del programa, entiende que ofrecer a las audiencias otra mirada sobre su propia realidad incide de forma positiva en su acontecer cotidiano, en uno de los programas, expresa "si mostramos la importancia de la organización entre nosotros, los padres nos van a tener en cuenta".

Este lineamiento se profundiza a través de los testimonios de quienes brindan entrevistas a los cronistas, que son sus propios vecinos, en los primeros programas aparece de manera recurrente la idea de que "A los jóvenes hay que ayudarlos... no juzgarlos". En esta línea, en el primer programa los y las jóvenes que coordinan un Centro Comunitario de Bernal Oeste comentan "Me gusta ayudar al barrio, quiero que sea mejor para mi y para toda mi familia (...); este barrio se está cayendo, y entre todos lo tenemos que levantar", dice Federico Acuña, otro joven participante.

"Cronistas Barriales" se posiciona como el espacio propicio para hacer escuchar lo que los y las jóvenes tienen para decir, apostando por la verdadera pluralidad de voces y la democratización de los medios de comunicación.

\section{Una política pública}

La implementación del proyecto "Cronistas Barriales" impone el desafío de asumir la complejidad de las nueva problemáticas sociales, en una coyuntura atravesados por la desigualdad social. De este modo, se retoma la posición de Carballeda (2013) al asumir que el dolor y el padecimiento se expresan tanto en los cuerpos como en las formas de relación social. Por lo tanto, cuando aquellos son atravesados por las distintas problemáticas sociales se alteran los modos de pensar la vida cotidiana y la relación con los otros. En este sentido, las intervenciones desde los diferentes ámbitos del Estado deben apuntar a la construcción de miradas transversales sobre dichas problemáticas y sus modos de abordarlas. Esto implica la necesidad de articular y coordinar las acciones entre las distintas esferas y ámbitos encargados de diseñar, implementar y evaluar políticas públicas junto con las organizaciones de la sociedad civil.

Es preciso resaltar, que el proyecto promovió la participación social en el proceso de toma de decisiones referidas al mismo. Así, por un lado, se dio un proceso de coordinación de acciones al interior de los organismos es- 
tatales del ámbito educativo: escuelas de nivel primario, escuelas de nivel secundario y universidad, en lo que podría entenderse como la articulación intersectorial, o sea, entre diferentes organismos estatales. En este caso particular, de jurisdicciones diferentes incluso, ya que las escuelas primarias y secundarias son de gestión provincial y la universidad del ámbito nacional.

Asimismo, el trabajo con las organizaciones sociales, se puede identificar con otra instancia de participación social en las cual se incorporan a los actores no estatales al proceso de diseño y gestión de las políticas sociales, modelo de intervención denominado gestión asociativa.

De esta manera, los procesos de tomas de decisiones resultan no ya de la exclusiva facultad de los decisores públicos, sino de la interacción y las dependencias mutuas entre las instituciones políticas y la sociedad.

El trabajo de Carballeda (2013) citado oportunamente, permite entender a la Intervención en lo Social como un instrumento de transformación no solo de las circunstancias donde concretamente actúa, sino también como un dispositivo de integración y facilitación del diálogo entre diferentes lógicas que surgen de distinta forma, comprensiva, explicativa, no solo de los problemas sociales, sino de las instituciones mismas.

Otro punto a tener en cuenta acerca del proyecto "Cronistas Barriales", es que surge en el marco la Ley 26522 de Servicios de Comunicación Audiovisual, sancionada en 2009. La Ley SCA implicaba un cambio de paradigma en la comunicación, al concebirla como un derecho humano y no como una mercancía, y al Estado lo concibe como garante de acceso a dicho derecho, mediante la creación de medios de calidad y accesibilidad para garantizar la llegada de los contenidos, como así también mediante la distribución del uso de espectro radioeléctrico en partes iguales para medios de comunicación comerciales, públicos y sin fines de lucro.

Asimismo, la Ley SCA se proponía entre otras cosas brindar el acceso a la producción de contenidos audiovisuales a universidades, escuelas, ONG, asociaciones sin fines de lucro, organizaciones sociales, comunitarias o barriales, entre otros actores a las cuales buscaba habilitarle canales para que pudieran expresar sus voces.

Esto quiere decir, que el proyecto "Cronistas Barriales" implica el desafío de gestionar la producción de noticias locales a través de la participación de los integrantes de las organizaciones sociales y escuelas que forman parte de la propuesta. 
En cada una de las organizaciones sociales se dieron procesos particulares, en función de las características, tiempos y lógicas de cada una de ellas. Sin embargo, siempre se partió de preocupaciones, inquietudes y problemáticas que los propios grupos identificaban como prioritarias. De esta forma, se produjeron informes con temáticas vinculadas a la historia de los barrios, cuestiones de injusticia ambiental, actividades comunitarias, perspectiva de género, entre otras temáticas. Es así que desde el proyecto se produjeron nuevos contenidos audiovisuales que trascendieron el mero hecho informativo, posibilitando objetivos pedagógicos desde relatos de historias barriales y de promoción de derechos. Así, desde formas de producción colectiva y un rol activo de los participantes que desde su propia mirada de la comunidad en la que están insertos y a partir de la apropiación de herramientas técnicas, pudieron producir informes audiovisuales.

Esta experiencia por lo tanto, se inscribe en el camino de aquellas perspectivas de abordaje de la intervención, que en diálogo con diversos campos de saber abre el camino hacia modelos de gestión participativa y de descentralización territorial y en este diálogo con la sociedad civil, busca poder articular lo producido por la crisis y la fragmentación de los lazos sociales. A partir de aquí es donde se discute el rol del Estado como un mero ejecutor de estrategias generales surgidas de manuales de procedimientos elaborados para supuestas poblaciones con sujetos y contextos homogéneos que poca utilidad tienen en los escenarios sociales fragmentados por la ruptura o ausencia de lazos, con su consecuente impacto en los sujetos.

También es oportuno mencionar que Cronistas Barriales realizó capacitaciones incorporando el uso de las herramientas tecnológicas que vienen incluidas en otra política pública como es la distribución gratuita de Netbooks del Plan Nacional "Conectar Igualdad" que insertó 3 millones de computadoras con el objetivo de achicar la brecha digital, explorando nuevos formatos televisivos, entre ellos el videoclip, articulando literatura y audiovisual, y utilizando las redes sociales con las herramientas de software y hardware que están incluidas con la computadora.

\section{Pedagogía y comunicación en cronistas barriales}

El proyecto de extensión Cronistas Barriales entiende a la educación y la comunicación como una relación dialógica. Esto implica entender estas disciplinas como campos relacionales, en constante fusión y retroalimentación. 
Podemos pensar que en ese diálogo operan un conjunto de discursos, normas, reglas, códigos y lenguajes amparados en tradiciones propias del campo.

Así como la educación tradicional ha instaurado un modelo unidireccional del saber, donde el conocimiento oficial nace siempre desde la misma voz y es depositado en sujetos vacíos a los que hay que adoctrinar; los modelos comunicacionales hegemónicos también tienden a monopolizar la información con una única voz: en general estridente, ruidosa, que pretende silenciar cualquier posibilidad de otras voces disímiles.

Desde este marco, Cronistas Barriales pretende constituirse en una situación de diálogo: tramar, narrar, conocerse, preguntar y preguntarse. Educar y comunicar, parece ser entonces eso que se trama siempre y cuando seamos conscientes de quiénes somos, dónde está nuestro lugar y qué queremos decir de él.

La extensa y valiosa literatura freireana, que pone en valor la comunicación y la educación como punto de partida, no hace más que referirse a la tarea primordial de reconocerse: No podemos educar y comunicar si nos desconocemos y más aún, no podemos hacerlo si no resignificamos aquello que dicen de nosotros. Para esta tarea, constituirse en una situación de diálogo es parte sustantiva del proyecto.

Cristina Corea (2004) en este sentido, plantea lo siguiente:

El diálogo en condiciones estatales se da desde lugares instituidos -el que sabe y el que no sabe, el adulto y el niño, el maestro y el alumno-; para hablar con el otro uno solo tiene que ocupar su lugar en el dispositivo (...) Entonces el trabajo de comunicación es de permanente construcción de las condiciones: es necesario instituir cada vez el lugar del otro, el lugar propio e instituir el código, las reglas según las cuales se van a organizar las significaciones. Y este trabajo obliga a pensar, ya que el que crea las condiciones se está constituyendo en las reglas de la situación. Esto es constituirse en una situación de diálogo (p. 54).

Cronistas Barriales opera así, creando condiciones para reconstruir un código propio, un conjunto de significados identitarios y un lenguaje que hable de los/las jóvenes y los/las niños/as de los barrios.

Tomando como referencia la tipología que desarrolla Florencia Saintout (2013) en sus estudios sobre juventudes, donde distribuye en tres grandes grupos las formas convencionales en que los medios hegemónicos suelen representar a la jóvenes: los exitosos, los desinteresados y los peligrosos; el proyecto se sustenta en la necesidad de generar un discurso propio, contra 
hegemónico, y en la importancia de formar un espacio colectivo, un lugar de encuentro en donde lo prioritario sea circular y alzar la voz.

Se pretende representar lo que inquieta y preocupa del barrio, lo que emociona, duele, da alegría y enorgullece. En definitiva, hablamos de un trabajo que implica conocerse primero, describir el lugar donde se vive desde la propia mirada de quién allí vive, liberarse de las tipologías (ni desinteresados, ni delincuentes), y hacerse conocer como ellos mismos quieren presentarse al mundo.

Es interesante resaltar en este sentido, que cuando a dos de los participantes del proyecto se les pregunta ¿Qué les aporta Cronistas Barriales? Contestan al unísono y con seguridad: "Emoción y conocimientos": dos palabras hermanadas, que desde la perspectiva pedagógica tradicional intentaron mantenerse en divorcio. Lo que atraviesa el cuerpo y las emociones, desde este modelo conservador, se mantuvo siempre en lugares desvalidos a la hora de aprender y conocer (Rosso, 2015).

Emoción y conocimientos, tal vez sea la mejor forma de explicar que la práctica pedagógica y comunicacional si no habla de lo que somos y nos identifica, no genera ni produce ningún sentido.

El proyecto, asume entonces una enorme, compleja y necesaria responsabilidad; pero ésta no es singular, única y mucho menos es individual. Es la misma que asume cualquier educador y comunicador comprometido con la circulación y democratización de los saberes y las voces; representa los múltiples espacios colectivos de educación y comunicación popular que defendemos y sumamos a este proyecto: un modelo autogestionario que no se concibe sino es a partir del diálogo constante con el contexto político y social en el que se inscribe.

\section{La propuesta de trabajo: Dinámica de taller}

La dinámica de trabajo de Cronistas Barriales se concentra a partir de tres grandes ejes de trabajo que responden a las tres fases de la producción audiovisual: Preproducción, producción y posproducción.

Los espacios de encuentro se desarrollan mediante la dinámica de taller previendo un espacio comunicacional recíproco que implica reconocerle al grupo facultades de auto-organización y de interacción entre pares. La perspectiva de trabajo que asumimos como equipo, no solo está vinculada a un 
enfoque pedagógico liberador para generar procesos de autonomía, sino que también responde a una toma de posición sobre la comunicación entendida en el mismo sentido. En este punto es que la categoría de educomunicación trabajada por Mario Kaplún representa gran parte del proceso de nuestro trabajo, donde nos proponemos un modelo autogestionario, en constante diálogo con el contexto político social.

Desde esta perspectiva pedagógica los talleres promueven, en la etapa de la preproducción, la deconstrucción de las noticias con el fin de resignificar discursos estereotipados instalados por los grandes medios de comunicación. Se trabaja a su vez, en la importancia de reconocerse en aquel lugar estigmatizante en que los medios suelen ubicar a los barrios periféricos. Este reconocimiento como parte del proceso de concientización, permite pasar a la etapa de producción, casi como respuesta y consecuencia de lo anterior, donde se pretende posicionar a los integrantes del taller como sujetos transformadores, productores de sentido y constructores de sus propios relatos.

La propuesta de intervención del taller, se constituye así como la herramienta más adecuada donde el conocimiento se construye a partir de la propia actividad y la experiencia de los participantes.

\section{Los temas y el enfoque barrial}

Entre las producciones realizadas figuran temáticas muy identificadas con los barrios. En el Primer programa se mostraron las actividades del Centro Comunitario San Pedro San Pablo y talleres dictados en la Escuela de Educación Secundaria Técnica $N^{\circ}$ 8. Del primer tema abordado, se retrataron los planes educativos y culturales impulsados por el Centro ubicado en el barrio San Sebastián I, que además funciona como un comedor que alberga 180 chicos con sus familias; con testimonios de los coordinadores adolescentes, que antes asistían para comer y en la actualidad ayudan a los demás.

Del segundo tema, los cursos técnicos e informáticos en el colegio que se encuentra en el barrio IAPI; y programas de interacción con otras instituciones: lo que se produce en el establecimiento se destina a las familias de los alumnos y, además, se organizan donaciones.

Las carencias edilicias y de elementos necesarios para el correcto dictado de clases son muchas, y afectan el aprendizaje cotidiano de los estudiantes. Sin embargo, los jóvenes reconocieron que esa mirada sobre la situación 
ya está presente en los medios tradicionales, por lo que se priorizó la originalidad de su desempeño en la institución.

En el Programa $N^{\circ}$ 2: Orquesta de jóvenes e historia del Batallón de Arsenales 601 “Domingo Viejo Bueno”. Lo primero, sobre el conjunto de música popular compuesto por adolescentes, que funciona como un ámbito de contención frente a las pocas actividades artísticas impulsadas por el municipio de Quilmes en esa comunidad. Se comunicó en primera instancia la existencia de la orquesta juvenil y su valor en la contención de jóvenes y la promoción artística. Esta postura también responde a mostrar la voluntad que hay en los barrios para enfrentar las adversidades.

El segundo informe incluye declaraciones de vecinos que fueron testigos del intento fallido de copamiento del batallón por parte de miembros del Ejército Revolucionario del Pueblo (ERP), el 23 de diciembre de 1975. Se incluyeron imágenes de archivo y se reconstruyo parte del suceso, mediante una investigación de las consecuencias de la represión a través de las Fuerzas Armadas: violaciones a los derechos humanos sufridas por los vecinos del barrio, conocidos de las familias de los Cronistas Barriales.

Quedó plasmado el interés de los jóvenes en la historia y el acontecer político nacional. Nuevamente, nos encontramos que los medios tradicionales emiten mucho material relacionado con el terrorismo de Estado, por lo que se decidió de manera conjunta circunscribir la problemática al escenario barrial. De esta forma, se le dio a la cobertura una mirada original, con testimonios y material documental audiovisual.

Además, una de las preguntas iniciales de las entrevistas “¿qué pasó?”, fue inmediatamente continuada por el interrogante "¿cómo lo mostraron los medios?". Los chicos demostraron estar al tanto del debate actual sobre la parcialidad de los medios y con preguntas como esta, adoptaron una actitud al respecto.

El Programa No 3: Inundaciones del arroyo "Las Piedras" y Biblioteca "Del Otro Lado del Árbol". El primer tema es un problema recurrente para muchos de los barrios quilmeños, donde viven muchos Cronistas Barriales; se muestra desde adentro esta dura realidad, poniendo énfasis en las propuestas para revertir la situación. La irresponsabilidad de las empresas que lo contaminan se suma a la necesidad de obras estructurales para impedir la inundación sistemática. Se analizaron las acciones impulsadas hasta el momento y los mecanismos que pueden optimizarlas, sobre todo la organización COLCIC, de cuidado ambiental vecinal. 
El segundo, sobre una biblioteca y ludoteca destinada principalmente a chicos con problemas de salud, haciendo hincapié en la historia de superación de un matrimonio que perdió a su hija a causa de una enfermedad, y que la recuerdan a través de este lugar de contención para niños vulnerables.

La cuarta emisión, la Organización "Decir Basta", Proyecto "Roperito" y junta vecinal "Mejor vivir". El tema inicial del envío fue una cobertura sobre la ONG, basada en la asistencia y acompañamiento a mujeres víctimas de violencia de género.

Luego, se cubrió periodísticamente una iniciativa de la Secretaría de Desarrollo Social de la municipalidad, basada en el reciclaje. Con los materiales aptos para su reutilización se fabrican muebles y ropa que son entregados a distintas organismos sociales. En lo referido a la junta vecinal, los chicos entrevistaron a sus referentes, que luchan para optimizar la calidad de vida del barrio "La Nueva Esperanza".

Cronistas Barriales, en sus dos años de recorrido, ha transformado y dado la posibilidad a los jóvenes de poner en valor sus prácticas, sus saberes, sus sentimientos no sólo ante sus propios pares en las escuelas, sino también en las redes sociales y en diversos eventos académicos y culturales.

En los programas siguientes hasta la emisión número trece, se renueva el tratamiento de las organizaciones de lucha contra la violencia de género, el debate sobre la baja de la edad de imputabilidad impulsada por el gobierno neoliberal vigente en argentina para criminalizar la protesta social, la obra de Don Bosco que trabaja en la recuperación de jóvenes adictos a la pasta base, o las experiencias de comunicación comunitaria o popular.

Sin ninguna duda, uno de los elementos de mayor visibilidad del proyecto es mediante la circulación por redes sociales, que son a su vez el principal medio de comunicación de los nativos digitales. Si bien habían salido varias notas sobre los "Cronistas barriales" en los medios locales y en las noticias propias de la Universidad, la potencialidad de la red social propicio el contacto con varias instituciones provinciales y encuentros académicos o programas públicos.

\section{Conclusiones}

Los procesos de construcción y disputa por un paradigma de la comunicación social como derecho humano inalienable es blanco permanente de 
tensiones con el poder mediático y comunicacional que en América Latina se encuentra inmensamente concentrado y bajo el criterio de una comunicación como mercancía que es ampliamente influyente sobre los sistemas democráticos, apropiándose del capital destinado por el Estado a la comunicación pública y acaparando la riqueza del mercado sin permitir el ingreso de nuevos actores al campo, pequeños y medianos empresarios y sectores sin fines de lucro.

Los Principios sobre regulación de la publicidad oficial y libertad de expresión elaborados por la Relatoría Especial para la Libertad de Expresión de la Comisión Interamericana de Derechos Humanos emitió en 2012 un documento que reúne un conjunto de definiciones y recomendaciones entre los que se plantea que existen distintas formas de afectar ilegítimamente la libertad de expresión, desde el extremo de su supresión radical mediante actos de censura previa hasta mecanismos menos evidentes, más sutiles y sofisticados que tienden a impedir la comunicación y la circulación de ideas y opiniones. Sin lugar a dudas, estos mecanismos que atacan a la comunicación también debilitan la democracia.

En consecuencia, las estrategias de articulación entre universidades, gobiernos locales y organizaciones sociales son fundamentales para construir instrumentos que mejores la calidad de vida organizando los esfuerzos para hacer de la comunicación social y la educación también políticas públicas.

Cronistas Barriales son un fiel ejemplo de ello. http://tv.unq.edu.ar/cro nistas-barriales/

\section{Bibliografía}

Carballeda, Alfredo J.M. (2013). La intervención en lo social como dispositivo. Una mirada desde los escenarios actuales. Trabajo Social- UNAM VI Época, 1. Ciudad de México.

Corea, Cristina (2004). Pedagogía y Comunicación en la era del aburrimiento. En Cristina Corea e Ignacio Lewcowicz, Pedagogía del aburrido. Paidos Ibérica.

Rosso,Laura (2015). Cronistas Barriales. Suplemento “La Ventana”. Diario Página/12. https://www.pagina12.com.ar/diario/laventana/26-272577-2015-05-13. html

Saintout, Florencia (2013). Los jóvenes en la Argentina. Desde una epistemología de la esperanza. Editorial Universidad Nacional de Quilmes. 


\section{Videografía}

http://tv.unq.edu.ar/cronistas-barriales-programa-n-14/ http://tv.unq.edu.ar/cronistas-barriales-programa-n-13/ http://tv.unq.edu.ar/cronistas-barriales-programa-no-12/ http://tv.unq.edu.ar/cronistas-barriales-programa-n-11/ http://tv.unq.edu.ar/cronistas-barriales-programa-n-10/ http://tv.unq.edu.ar/cronistas-barriales-programa-n-09/ http://tv.unq.edu.ar/cronistas-barriales-programa-n-08/ http://tv.unq.edu.ar/cronistas-barriales-programa-07/ http://tv.unq.edu.ar/cronistas-barriales-programa-06/ http://tv.unq.edu.ar/cronistas-barriales-programa-05/ http://tv.unq.edu.ar/cronistas-barriales-programa-no-4-13-09-2013/ http://tv.unq.edu.ar/cronistas-barriales-2013/ http://tv.unq.edu.ar/cronistas-barriales-programa-02-13122012/ http://v.unq.edu.ar/cronistas-barriales-programa-01-25102012/

Fecha de recepción: 21/06/2017; fecha de aceptación: 07/08/2017; fecha de publicación: 01/09/2017 



\title{
Percepción de la competencia mediática y la formación en maestros chilenos \\ Perception of media literacy and training in teachers from Chile
}

\author{
Pablo Maraver-López ${ }^{1}$ \\ pablomaraverlopez@gmail.com \\ Mari-Carmen Caldeiro-Pedreira ${ }^{2}$ \\ mariccaldeiro@gmail.com \\ Sandra Pérez-Lisboa ${ }^{3}$ \\ sandra.perez@upla.cl
}

\begin{abstract}
Resumen
El presente trabajo analiza la realidad educativa de la zona de Los Andes respecto a los conocimientos tecnológicos que los maestros poseen en el ámbito de las nuevas tecnologías (TIC), también busca conocer los recursos con los que cuentan en el aula y el uso que realizan de los mismos. En el estudio se ha utilizado una metodología analítica y cuasi experimental a través de varias encuestas (pretest y postest). Los datos obtenidos pretenden justificar el uso de las TIC en las escuelas y el conocimiento que los maestros participantes poseen. Además de ello, focaliza la atención el peso que las TIC tienen en el currículo de educación en Chile y los programas y estrategias pedagógicas existentes en el país.
\end{abstract}

\section{Palabras clave}

Alfabetización mediática, competencia, currículo educativo, formación, maestros, Chile.

Forma sugerida de citar: Maraver-López, Pablo, Caldeiro-Pedreira, Mari-Carmen, \& PérezLisboa, Sandra (2017). Percepción de la competencia mediática y la formación en maestros chilenos. Univeristas, XV(27), pp. 211-230.

1 Doctor en Ciencias de la Educación. Profesor en el Departamento de Psicología social, evolutiva y de la educación de la Universidad de Huelva (España). Miembro del Grupo de Investigación Ágora HUM 648 y miembro de la Red Internacional Alfamed. Orcid: 0000-0003-2457-0887.

2 Doctora en Comunicación y Educación. Profesora del departamento de Psicología y Pedagogía de la Universidad Pública de Navarra (España). Profesora en diferentes universidades de España y Latinoamérica (Chile y Ecuador). Miembro del Consejo Técnico y del Consejo de Revisores (Advisory Board) de la Revista Científica de Comunicación y Educación "Comunicar". Académica a tiempo completo y coordinadora del Área de Investigación en el Campus de San Felipe de la Universidad de Playa Ancha (Chile). PhD en la Universidad Técnica del Norte (Ibarra, Ecuador). Investigadora en el Center for Higher Education Studies (República Checa). Orcid: 0000-0003-0160-3682.

3 Magíster en Pedagogía y Gestión Universitaria, Universidad Metropolitana de Ciencias de la Educación. Educadora de Párvulos, Pontificia Universidad Católica de Chile; Psicopedagoga. Docente del Departamento Disciplinario de Educación y Pedagogía, Universidad de Playa Ancha, Campus San Felipe. Orcid: 0000-0002- 0389-7242. 


\begin{abstract}
This paper analyzes the educational reality of Los Andes area with respect to the technological knowledge that teachers have in the field of new technologies (ICT), it also seeks to know the resources they have in the classroom and the use they make of them. In the study an analytical and quasi-experimental methodology has been used through several surveys (pretest and postest). The data obtained are intended to justify the use of ICT in schools and the knowledge that the participating teachers possess. In addition, attention is focused on the importance of ICTs in the education curriculum in Chile and the pedagogical programs and strategies that exist in Chile.
\end{abstract}

Keywords

Media literacy, skills, curriculum, training, teachers, Chile.

\title{
Introducción y estado de la cuestión
}

Hoy en día, la sociedad digital a la que se han referido autores como Terceiro (1996) o Tornero (2005), los nativos e inmigrantes digitales o la alfabetización digital y mediática son términos relativamente comunes. Así, la educación en sus diferentes niveles e independientemente del país al que nos refiramos, debe hacerse eco de ello. El ecosistema tecnológico circundante demanda un giro irremediable en el ámbito educativo, una modificación que ha de realizarse a nivel mundial en los distintos niveles educativos. Una afirmación que mantienen, entre otros, López, Opertti y Vargas (2017) en el informe sobre adolescentes y jóvenes en realidades cambiantes.

De la realidad actual se desprende la imperante necesidad de realizar innovaciones a gran escala, mejoras que justifican el interés de organizaciones de carácter mundial como la UNESCO. Organismos que focalizan la atención en mejorar y transformar los sistemas, un hecho que preocupa a la administración de los diferentes países y a los diversos gobiernos que intentan dotar de herramientas tecnológicas a la mayor parte de las instituciones y centros educativos. En este sentido la Organización de Naciones Unidas $(\mathrm{ONU})$ examina qué funciones pueden cumplir las TIC en la concepción de 
las políticas educativas atribuyéndole a la UNESCO el desempeño de una función normativa e informativa justificada por el acopio de datos y ejemplos sobre el uso de las TIC en el ámbito educativo. Además de ello pretende diseñar y elaborar diversos informes que muestran la información al respecto.

En este contexto cambiante, de renovación normativa, social y política se desarrolla la investigación que presentamos, un análisis de la realidad mediática actual que se produce en la denominada "sociedad líquida" (Bauman, 2000) donde todo cambia y pocas cosas permanecen, una sociedad en la que impera la obsolescencia programada, tanto de herramientas como de contenidos. En este espacio donde la presencia de los medios es rotunda (González-Fernández, Salcines-Talledo y Maraver-López, 2016), la información y los contenidos audiovisuales poseen un valor perecedero que puede atribuírsele a la multiplicidad de pantallas, la interactividad o la virtualidad. Aspectos todos ellos que impiden que se obvie la realidad y se oponen al continuo uso en las aulas de herramientas y estrategias didácticas propias de momentos anteriores donde imperaban pedagogías pasadas. Más allá de la visión de apocalípticos e integrados, en la era de la interactividad puede afirmarse con rotundidad que la perspectiva de unos y otros ha sido superada tanto por la tecnología como por los propios principios; en este sentido hoy en día existen diferentes estudios como los realizados por (RamírezGarcía, Renés-Arellano, Aguaded, 2016) que muestran la realidad en las aulas y justifican la necesidad de inclusión de nuevos proyectos centrados en el desarrollo de la competencia mediática por parte del alumnado. Para ello se apuesta por la formación continua del profesorado como indican Caldeiro y Aguaded (2012). Una formación que la UNESCO en su web identifica con el avance y la calidad docente que trasciende el marco teórico y se apoya en estándares tecnológicos referidos no solo a esta dimensión sino también a la producción reflexiva y crítica de contenidos. Especialmente hoy en día el profesorado ha de ser capaz de ayudar a los estudiantes para que trabajen, resuelvan problemas y desarrollen un aprendizaje creativo a través de las TIC. Para ello la UNESCO establece en su web una categorización en niveles que determina el grado de desarrollo y alcance de la competencia digital docente.

-En primer lugar hace referencia al aprendizaje de los elementos básicos de la tecnología, que permite el uso de las TIC por parte de los estudiantes y favorece el aprendizaje activo. 
-El segundo nivel se centra en la profundización del conocimiento, que permite que los estudiantes adquieran conocimientos más avanzados de las asignaturas escolares y los apliquen a problemas complejos de la vida real.

-El tercer nivel guarda relación con el desarrollo de la capacidad de creación de nuevos conocimientos que contribuyen a la forja de sociedades armoniosas.

En cuanto al alcance de conocimientos, cabe destacar que apuesta por la alfabetización y el aprendizaje permanente adaptado a las necesidades de cada persona, independientemente de su situación o procedencia. En este sentido, centra la atención el aprendizaje permanente que englobe toda la actividad de adquisición de conocimientos, ya sean de carácter formal o informal, con el fin de mejorar las habilidades y las competencias, exigiendo un cambio de modelo que ponga énfasis en el aprendizaje, frente a la enseñanza y la capacitación (UNESCO, 2014) de manera que se promueva un cambio en los valores y actitudes (Quendler y Lamb, 2016).

Esta situación no es exclusiva del continente europeo y atiende, como señala la UNESCO (2016) en el apartado dedicado a buenas prácticas, a "las experiencias del Instituto Nacional de Educación Abierta de la India o los programas de RVA de Chile, México y Brasil". A estos ejemplos se suma el de Colombia donde se están desarrollando iniciativas que favorecen el alcance de la competencia mediática en la ciudadanía y de forma específica entre el alumnado y el profesorado (Sandoval et al., 2016).

Una realidad que no solo se hace extensible a otros países como Brasil, Ecuador o Chile sino que además, está presente en las políticas educativas que hacen referencia al uso de las TIC y su presencia en los planes de estudio. Una presencia que al igual que en el caso de España figura de forma tímida en el currículo donde se incluyen contenidos transversales o algunos específicos vinculados a la dimensión de la tecnología más que a las de análisis y producción de contenidos.

\section{Alfabetización digital y mediática}

La realidad social circundante ha planteado la necesidad de que se asista al desarrollo de nuevas formas de aprender acorde a la existencia de nuevos medios y herramientas digitales. A lo largo de las últimas décadas del siglo XX diferentes organismos preconizaban la necesidad de preparar para con- 
vivir en un mundo dominado por las imágenes y los sonidos. Entonces ya se preveía el valor y el carácter de poder de los mismos si bien la presencia de los medios no poseía un carácter general ni se había extendido al nivel actual. Con el paso de los años la situación ha alcanzado límites insospechados, hoy en día la tecnología se ha convertido en un marco de referencia no solo comunicativo sino también de enseñanza y de aprendizaje.

En este sentido la alfabetización ha perdido el valor inicial que hacía referencia al aprendizaje de estrategias lecto-escritoras y ha alcanzado una dimensión digital connatural a la era mediática donde imperan las herramientas y medios tecnológicos que transmiten contenidos al instante. En este contexto la alfabetización digital ya no representa una opción sino que se ha convertido en una necesidad que es posible explicar atendiendo a una serie de criterios como: el funcionamiento de los motores de búsqueda y selección de la información que se difunde de manera desmesurada hoy en día, la gestión de la información, la privacidad o los derechos y libertades que se derivan de la emisión y la recepción de contenidos. En esta línea la alfabetización digital no consiste únicamente en "enseñar a utilizar el ordenador y distintas aplicaciones informáticas, sino que debe ofrecer los elementos básicos para la comprensión y dominio del lenguaje en el que están codificados los programas" (Levis, 2006, p. 78). La tecnología y su implantación general en el ecosistema actual demanda sujetos preparados, capaces no solo de decodificar adecuadamente sino de discernir y saber buscar información correctamente (Badwen, 2002). Esta idea discurre de forma paralela a los principios que se desprenden de la política europea que focaliza el interés en la formación del profesorado como estrategia básica para fortalecer la mejora de la calidad educativa.

Si nos referimos al contexto europeo, la formación se considera obligatoria en 28 sistemas educativos europeos siendo indispensable para la promoción en buena parte de ellos. Pese a que los docentes están preparados en sus materias, consideran que requieren formación en métodos didácticos, es decir, en el diseño de materiales adaptados a las necesidades más recientes. Por ende, esta idea enlaza de forma directa con la de alfabetización mediática que propugnaba el CML (2003) al referirse al conjunto de herramientas necesarias para el alfabetismo en medios. Asimismo el CML, cree fundamental conocer: quién es el creador del mensaje, qué técnicas creativas se usan para llamar la atención, qué formas o maneras de comportamiento experimenta la audiencia de un mensaje, qué valores 
incorporan y por qué se envían. Por ello, define el proceso de alfabetismo en medios como el conjunto de habilidades que capacitan para acceder a los mensajes, analizarlos, evaluarlos y crearlos, todo ello de forma crítica y reflexiva. Una idea que se ha complementado y propagado a lo largo de la última década de tal forma que hoy en día, en diferentes países no solo del contexto europeo sino también del latinoamericano, contamos con experiencias en alfabetización que inciden en la formación del profesorado de niveles iniciales (Unesco, 2014b). Diferentes modos de alfabetizarse que inciden, en el desarrollo de "pedagogías emergentes" (Pérez-Lisboa y Caldeiro, 2017), modos de aprender y enseñar que promueven el alcance de la "competencia crítica" (Caldeiro y Aguaded, 2015) con base en el aprendizaje para todos (Unesco, 2016). Criterios que a su vez deben ser evaluados con el fin de valorar el nivel de consecución de los objetivos y de estandarizarlos; en esta línea destacan estudios como el dirigido por Pérez-Tornero (2009) que si bien está referido al ámbito europeo, podría utilizarse de modelo en otros contextos dado que busca facilitar el análisis y los criterios apropiados para la evaluación de los niveles de alfabetización mediática teniendo en cuenta el conjunto de políticas que se desarrollan en este ámbito. De un modo similar en países como Chile se han desarrollado programas de formación docente (Bitar, 2011) inspirados en diversas investigaciones que han salido a la luz a lo largo de la primera década del actual siglo y describen los estándares TIC para la formación inicial docente (Unesco, 2008). Iniciativas cuyo valor resulta significativo y al mismo tiempo sirven para analizar las diferencias y similitudes que pueden establecerse a nivel internacional.

Pese a todo, no existen proyectos concretos que puedan identificarse con la competencia mediática y su desarrollo, si bien se cuenta en este sentido con el esfuerzo de la Red Internacional Alfamed que se está desarrollando en diferentes países del contexto latinoamericano entre los que se encuentra Chile. Además de ello existen iniciativas como Mediabus que buscan conciliar posturas que vinculen la educación en medios y la escuela, principalmente rural. Proyectos que se llevan a cabo en el marco de convenios que la fundación que promueve la innovación e inclusión educativa establece con diversas universidades que imparten las carreras de pedagogía en sus diferentes ramas. Estas iniciativas pueden vincularse de forma indirecta con el desarrollo de la competencia mediática en tanto que favorecen la autonomía, la reflexión y la creatividad. Se trata de proyectos que apuestan por el alcan- 
ce de la competencia crítica con base en la producción y análisis de contenidos audiovisuales por parte de los futuros docentes.

La competencia mediática como forma de expresión crítica: más allá de la competencia audiovisual y la digital

La tecnología de la información, la práctica docente y los objetivos de la educación entendida esta última de forma genérica y no como la mera educación escolar, deben tender hacia el alcance de sujetos reflexivos, participativos y críticos, capaces de interactuar en la sociedad de la información, el conocimiento y la virtualidad. Para ello resulta imprescindible la inclusión de nuevas herramientas en al ámbito pedagógico, una inclusión a la que debe sumarse el alcance de niveles elevados en competencia mediática entendida como la habilidad conformada por la dimensión de: la tecnología, lenguajes, interacción, producción y difusión valores y estética. Dimensiones todas ellas que se configuran, siguiendo a (Ferrés y Piscitelli, 2012) en torno a dos grandes ámbitos: análisis y expresión y que conllevan el desarrollo de indicadores que pueden utilizarse para definir el nivel de producción de contenidos del receptor, también conocido como "prosumer" (SánchezCarrero y Contreras, 2012).

En este sentido la competencia mediática trasciende a la digital y audiovisual completándolas en tanto que hace hincapié no solo en el uso tecnológico y el manejo de las herramientas digitales ni tampoco en el análisis de contenidos sino que establece un conjunto de dimensiones que debe desarrollar un receptor activo que pertenece a la sociedad multipantalla (Ortiz, 2008) en la cual más allá del consumismo se busca el alcance y desarrollo de la actitud reflexiva y crítica que se opone a la proliferación de conductas perniciosas derivadas del incorrecto manejo de los dispositivos tecnológicos y de la lectura errónea de los contenidos audiovisuales. Además, en la actualidad impera la necesidad de empoderar a los usuarios de por ejemplo, las redes sociales que se han convertido en uno de los medios de comunicación más utilizados, especialmente entre el colectivo adolescente. En este sentido y según afirmaban (Tejedor y Pulido, 2012) conviene tener en cuenta los retos y riesgos de la red y la virtualidad. Hoy en día, además de leer la información constituye una necesidad perentoria su correcta decodificación y adecuada producción, especialmente en un momento en el cual se difunde de manera inmediata y en ocasiones irregular. 
Por tanto resulta fundamental el desarrollo de la competencia mediática en cada una de sus dimensiones; asimismo constituye una necesidad imperiosa alfabetizar no solo a los menores sino a la población en general y de forma especial a los docentes y a los progenitores que pertenecen al grupo de los "visitantes digitales" (White y Le Cornu, 2011). En la sociedad móvil digital actual conviene que los "natitantes” (Fernández-García, Blasco y Caldeiro, 2016), es decir los nativos y los visitantes digitales, se interrelacionen tanto si conviven en un mismo espacio presencial como si es virtual. Independientemente del nivel de desarrollo y manejo de las tecnologías y de la capacidad de decodificar los contenidos audiovisuales "visitantes y residentes digitales" (White y Le Cornu, 2011) han de desarrollar el nivel óptimo de competencia mediática que les capacita para expresarse de forma crítica y autónoma y para desenvolverse en medio de superabundancia de información que tiende a la sobrecarga desmedida también denominada "infopolución” o "infoxicación” (Aguaded, 2014).

Para ello se propone la educación en medios también denominada "educomunicación" que aboga por la formación para los medios, una tarea que resulta compleja teniendo en cuenta que la competencia mediática no figura entre aquellas que componen el currículo. Si bien si puede vincularse de forma transversal e interdisciplinar en la práctica totalidad de asignaturas y programas formativos.

\section{La realidad chilena}

En las últimas décadas, las políticas educacionales que se han impulsado en Chile en busca de mejorar la calidad han permitido innovar y modernizar los aprendizajes en la sala de clases. En este contexto destaca la iniciada en el año 1992, con la creación del proyecto piloto Enlace que tiene como objetivo integrar las TIC en la educación para mejorar los aprendizajes. Por los resultados obtenidos, este proyecto se transforma en el año 2005 en el Programa Enlace, dependiente del Ministerio de Educación como Centro de Educación y Tecnología de Chile. Entre sus objetivos destaca la incorporación de ordenadores, software e Internet en las escuelas de todo el país. A nivel curricular, con la reforma Educacional del año 1998, se ha incorporado informática en Educación Media, para lograr desarrollar capacidades de manejo de software, y de búsqueda y selección de información, objetivos que coinciden con los del CML, anteriormente 
señalados. Más adelante, en el año 2001, se crea el portal educarchile.cl, con el objetivo de mejorar la calidad de la educación, brindando recursos, servicios y experiencias educativas para los docentes, estudiantes y familias. Al año siguiente, se implementa el programa de Tecnologías de Información y Comunicación Efectivas para Educación TIC EDU de FONDEF (Fondo de Fomento al Desarrollo Científico y Tecnológico). Este programa TIC EDU, tiene como objetivo contribuir a elevar la calidad de la educación mediante el desarrollo de productos o servicios TIC innovadores orientados a mejorar los procesos de aprendizaje. A finales de 2014 se presentan los resultados de la segunda aplicación nacional de Evaluación de Habilidades TIC para el Aprendizaje. Unos resultados que afirman que el $46,9 \%$ de los estudiantes se encuentran en un nivel Inicial frente al 51,3\% de los estudiantes que alcanzan un nivel Intermedio y tan solo el 1,8\% obtiene el nivel Avanzado. Para fortalecer la Educación Pública, el actual gobierno de la Presidenta Michelle Bachelet creó otro programa llamado 'Me conecto para aprender', que permite facilitar ordenadores a todos los estudiantes de establecimientos municipales de $7^{\circ}$ año de educación básica. Además este programa incluye a lo largo de un año banda ancha móvil gratuita y diversos recursos educativos que los estudiantes tienen a su disposición por asignatura, con simuladores y programas de imágenes y audio para realizar sus tareas y trabajos investigando en diferentes sitios de la red. Este gobierno espera hacer llegar a los centros, entre los cuales ha incluido en 2016 a estudiantes adultos, un total de 300 mil ordenadores. La realidad refuerza, en el caso de Chile que existe una gran presencia de los nuevos dispositivos tecnológicos y una ligera y continua inclusión de los mismos en el ámbito académico.

Por tanto, descrito el contexto mediático actual y la presencia de estos contenidos en el ámbito educativo y en sus correspondientes políticas, es necesario perfilar de forma concreta los principales objetivos de la investigación que se presenta. El Objetivo general es analizar la percepción de la competencia mediática y la formación en maestros chilenos. Para ello, se plantean los siguientes objetivos específicos:

Objetivo 1: analizar la realidad educativa de la zona de Los Andes respecto a los conocimientos tecnológicos que el profesorado posee en el ámbito de las TIC. 
Objetivo 2: conocer los recursos con los que cuentan en el aula y el uso que realizan de los mismos. Objetivo 3: indagar sobre la importancia que el profesorado otorga a las TIC para la educación actual y analizar su percepción sobre las habilidades que creen tener y el conocimiento de los intereses y preferencias de sus estudiantes.

Objetivo 4: conocer las ventajas y limitaciones que el profesorado manifiesta respecto al uso de las herramientas tecnológicas en el aula.

Objetivo 5: analizar el impacto de un curso de formación sobre competencia mediática para el profesorado.

\section{Material y métodos}

Para cumplir con los objetivos propuestos, se ha utilizado una metodología analítica, en concreto, se trata de un estudio pre-post, que permite una recolección de datos clara, rigurosa y confiable. El tipo de investigación es de tipo cuasiexperimental que permitirá determinar el grado de relación o asociación no causal existente entre las variables del estudio.

\section{Procedimiento}

El presente estudio se llevó a cabo en el contexto educativo de la región de los Andes en Chile. La información que arrojan los datos referidos se ha extraído del análisis e impacto de un curso de formación ofrecido al profesorado en el cual se ha realizado una presentación general sobre el aprendizaje por competencias que se ha iniciado en el Informe DeSeCo (1998) y más concretamente sobre competencia mediática. Los datos fueron recogidos a través de dos cuestionarios elaborados ad hoc que pretenden analizar los conocimientos y competencias del profesorado frente a las TIC.

\section{Participantes}

En este estudio han participado un total de 31 maestros y maestras de una escuela de Los Andes (Chile). Se trata de una institución que dispone de ordenadores y que se encuentra inmersa en el programa de digitalización del gobierno si bien, como indican los participantes, carecen de formación adecuada para la inserción de las herramientas en el quehacer diario. 


\section{Instrumentos}

Para esta investigación se han empleado dos instrumentos: un cuestionario inicial sobre los conocimientos y percepciones que los docentes de infantil y primaria poseen acerca de las TIC en la educación y un segundo cuestionario de valoración de una actividad formativa sobre las TIC en la que el profesorado ha participado. Es decir, al principio el profesorado ha respondido a un cuestionario inicial y al finalizar la formación han cumplimentado el cuestionario final.

\section{Análisis y resultados}

Los resultados que se exponen a continuación siguen el mismo orden que los objetivos de la investigación.

Objetivo 1: Resultados sobre los conocimientos tecnológicos que el profesorado posee en el ámbito de las TIC.

Para dar respuesta a este objetivo, se realizaron varias preguntas al profesorado respecto al conocimiento que poseen sobre el término alfabetización, el término competencia mediática y la necesidad de formación del docente para el uso de las TIC en el aula (Figura 1). 
Figura 1

Conocimientos tecnológicos del profesorado en el ámbito TIC

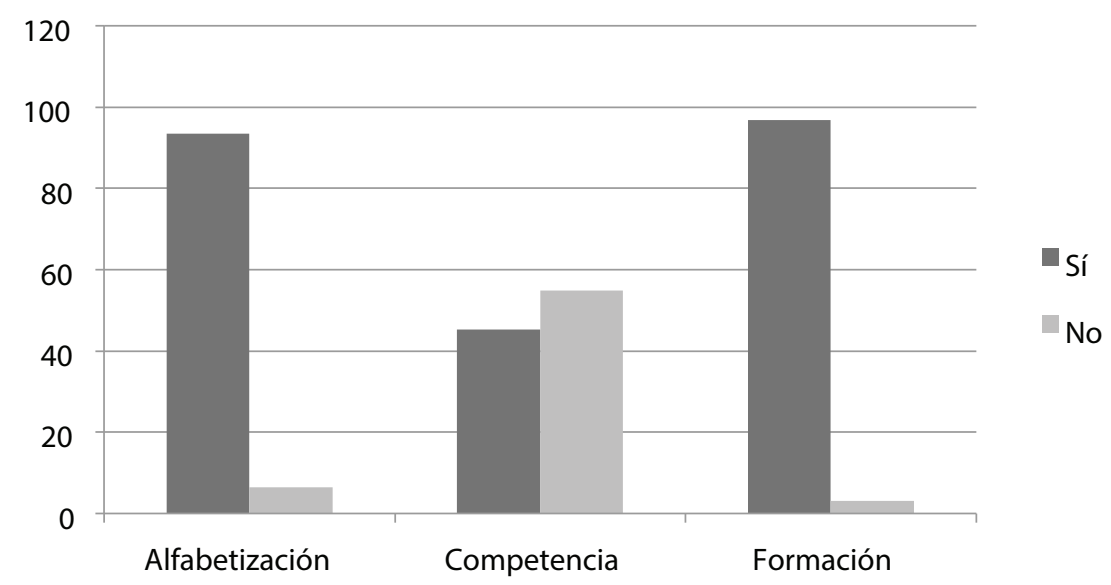

Fuente: Elaboración propia

En esta primera encuesta, previa a la actividad formativa, el 93,5\% de profesorado encuestado afirma conocer el término alfabetización. Al mismo tiempo, el 45,2\% afirma conocer el término competencia mediática, frente al 54,8\% que aún no lo conoce. Por otra parte, el 96,8\% de las personas encuestadas considera necesaria la formación del docente para el uso de las TIC en el aula.

Objetivo 2: Resultados sobre los recursos con los que cuentan en el aula y el uso que realizan de los mismos.

El 100\% del profesorado encuestado confirma que su centro cuenta con herramientas tecnológicas.

A pesar de ello, el 77,4\% utiliza herramientas tecnológicas en sus clases frente a un 22,6\% que no las utiliza. La frecuencia de uso de las personas que sí utilizan TIC en sus clases se puede ver en la Figura 2. 


\section{Figura 2 \\ Frecuencia de uso de las TIC por parte del profesorado}

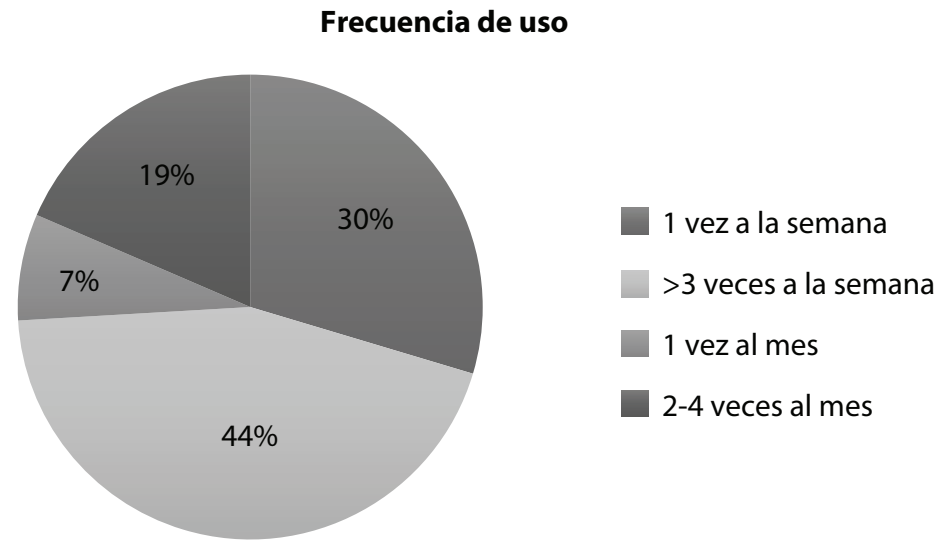

Fuente: Elaboración propia

Tal y como se observa en la Figura 2, un 29,6\% utiliza las TIC una vez a la semana; El 44,4\% más de tres veces a la semana; El 7,4\% la utilizan una vez al mes; Y el 18,5\% hace uso de las TIC más de una vez al menos y menos de 4 veces.

Objetivo 3: Resultados sobre la importancia que el profesorado otorga a las Tic para la educación actual y analizar su percepción sobre las habilidades que creen tener y el conocimiento de los intereses y preferencias de sus estudiantes.

En la encuesta, el 97\% de profesores se ha mostrado totalmente de acuerdo con esta afirmación "Las TIC son necesarias en la educación hoy en día".

Además, el 94\% ha respondido que conoce las necesidades del estudiante de hoy en día.

Otra cuestión aborda "Cuáles son las inquietudes preferentes del alumnado". Gracias a las respuestas abiertas obtenidas podemos observar que el profesorado detecta que los intereses e inquietudes de su alumnado son: 
- Aprender de un modo significativo, información de interés para el alumnado, a través del uso de las TIC e innovar.

- Buscar información, jugar en red, comunicarse a través de redes sociales.

- Llevar a cabo clases interactivas, los estudiantes quieren hacer y participar, no quieren que un profesor hable durante toda la clase.

- Comunicarse con los pares.

- Buscar información y crear sus trabajos propios.

- Configurar y desarrollar tareas.

- Usar programas de interés para los estudiantes.

- Conectar la materia con las redes sociales.

- Jugar, investigar, manipular, aprender conceptos, navegar, chatear.

- Estar a la moda, ser parte de la sociedad.

- Estar actualizados en las redes sociales.

- Estar conectados al mundo y estudiar.

- Compartir conocimiento.

- Motivarse.

- Intereses sociales, sexuales y tecnológicos.

Objetivo 4: Resultados sobre las ventajas y limitaciones

que el profesorado manifiesta respecto al uso de las herramientas tecnológicas en el aula

A este respecto, el profesorado describe una serie de ventajas y limitaciones sobre el uso de las TIC en el aula (Tabla 1). 


\section{Tabla 1 \\ Ventajas y limitaciones del uso de las TIC en el aula}

\begin{tabular}{|c|c|}
\hline Las herramientas tecnológicas favorecen & $\begin{array}{l}\text { Las herramientas } \\
\text { tecnológicas dificultan }\end{array}$ \\
\hline "Aprendizajes significativos y lúdicos" & "Ante tantas opciones no saben que elegir" \\
\hline "Búsqueda de información rápida" & "Depende de las reglas que los padres tengan en sus casas" \\
\hline $\begin{array}{l}\text { "A los niños les gusta construir usando las TIC así que la clase } \\
\text { se vuelve significativa, mejora el clima dentro del aula" }\end{array}$ & $\begin{array}{l}\text { "No permite desarrollar comunicación o potenciar, } \\
\text { encasilla y coarta las respuestas" }\end{array}$ \\
\hline $\begin{array}{l}\text { "Ayudan a desarrollar competencias, expresar conocimientos, } \\
\text { habilidades, aprendizajes..." }\end{array}$ & $\begin{array}{l}\text { "Solo quieren usar las redes sociales y no para } \\
\text { aprender, no saben resumir o extraer información" }\end{array}$ \\
\hline "Facilita el aprendizaje del conocimiento" & "Afecta a la comunicación de personas más aisladas" \\
\hline $\begin{array}{l}\text { "Favorecen, motivan para aprender, ayudan a los profesores } \\
\text { que lo usan didácticamente" }\end{array}$ & "Entorpece" \\
\hline $\begin{array}{l}\text { "Facilita los aprendizajes especialmente en mates, el medio } \\
\text { audiovisual es motivador para desarrollar y estimular los } \\
\text { sentidos" }\end{array}$ & "La información no siempre es fidedigna" \\
\hline $\begin{array}{l}\text { "Facilita para poder exponer los contenidos adecuados, } \\
\text { favorece el conocimiento y la investigación" }\end{array}$ & "Es un arma de doble filo" \\
\hline $\begin{array}{l}\text { "Facilitan y mejoran la calidad de los aprendizajes, mayor } \\
\text { interés por aprender a través de las TIC" }\end{array}$ & $\begin{array}{l}\text { "Dificultan si hay mal uso en el aula y no presentan } \\
\text { atención" }\end{array}$ \\
\hline "Facilitan porque es interactiva y concreta" & $\begin{array}{l}\text { "Dificultan por el aumento de obesidad y falta de } \\
\text { actividad física" }\end{array}$ \\
\hline "Facilitan pues entregan información inmediata y complementa" & "Dificultan cuando el docente no maneja las TIC" \\
\hline \multicolumn{2}{|l|}{$\begin{array}{l}\text { "Favorece la atención de los niños, más conocimiento de la } \\
\text { era moderna" }\end{array}$} \\
\hline \multicolumn{2}{|l|}{ "Favorece un fácil acceso a la información" } \\
\hline \multicolumn{2}{|l|}{ "Facilitan el trabajo, obtener información pedagógica" } \\
\hline \multicolumn{2}{|l|}{$\begin{array}{l}\text { "Favorecen labor docente siendo un apoyo de interés para } \\
\text { alumnos, clases motivadoras y dinámicas" }\end{array}$} \\
\hline \multicolumn{2}{|l|}{ "Favorecen para el desarrollo del futuro en la tecnología" } \\
\hline \multicolumn{2}{|l|}{ Favorecen porque son motivadoras e innovadoras" } \\
\hline \multicolumn{2}{|l|}{ Favorecen pues da herramientas e información para el aprendizaje" } \\
\hline \multicolumn{2}{|l|}{$\begin{array}{l}\text { "Favorecen pues se obtiene información al momento y es } \\
\text { llamativo para alumnos" }\end{array}$} \\
\hline \multicolumn{2}{|l|}{$\begin{array}{l}\text { "Favorecen si son bien usados, con material que facilite en } \\
\text { aprendizaje" }\end{array}$} \\
\hline $\begin{array}{l}\text { "Favorecen al nivel de desarrollo e interés de los niños, } \\
\text { favorece aportan recursos y aprendizaje significativo" }\end{array}$ & \\
\hline
\end{tabular}




\begin{tabular}{|c|c|}
\hline Las herramientas tecnológicas favorecen & $\begin{array}{l}\text { Las herramientas } \\
\text { tecnológicas dificultan }\end{array}$ \\
\hline "Favorecen ya que les servirá en el futuro" & \\
\hline $\begin{array}{l}\text { "Favorecen ya que muestran un mundo de posibilidades por } \\
\text { descubrir }\end{array}$ & \\
\hline $\begin{array}{l}\text { "Favorecen, lo hacen más motivante y participativo, más } \\
\text { contextualizado" }\end{array}$ & \\
\hline
\end{tabular}

Fuente: Elaboración propia

De las opciones que refleja la Tabla 1 se deduce que la muestra participante considera que las herramientas tecnológicas y el uso de las TIC en el aula acarrean más ventajas que inconvenientes y subrayan entre los aspectos positivos la búsqueda de información que es una de las dimensiones que destaca en el Marco de competencia docente del Intef (2017).

\section{Objetivo 5: Resultados sobre el impacto de un curso de formación del profesorado}

Abordando este último objetivo, el 90,3\% de los maestros y maestras respondieron que la información recibida en la actividad formativa le ha interesado mucho.

Además, un 87,1\% consideró que la información trabajada en la actividad formativa le ayudó mucho a clarificar conceptos. Por su parte, el 93,5\% se mostraron interesados en conocer más información al respecto de esta temática. En relación a los materiales utilizados para la actividad formativa, un $84 \%$ de las personas participantes manifestaron que sí le han resultado adecuados.

Finalmente, al comparar las puntuaciones obtenidas en el cuestionario previo a la actividad formativa, con el cuestionario final, se obtienen diferencias estadísticamente significativas $(p<0.05)$ ante la pregunta "Conoces el término alfabetización" $100 \%$, frente un porcentaje inferior del profesorado que afirmaba conocer el término alfabetización antes de la formación lo cual significa que, conforme se señala en esta investigación, resulta imprescindible la formación acorde a las nuevas necesidades. En respuesta a la pregunta "Conoces el término competencia mediática" 97\% afirma conocer el término competencia mediática frente al $45 \%$ que afirmaban que lo conocían antes de iniciar del taller. Una respuesta que confirma la importancia de la formación continua del profesorado y su efectividad. 


\section{Discusión y conclusiones}

La realidad tecnológica y la ingente cantidad de contenidos audiovisuales que fluyen a través de los canales hipermedia, certifican el necesario cambio pedagógico. En Chile, el compromiso gubernamental consistente en dotar de herramientas a los centros y la tímida inclusión de informática en el currículo resulta insuficiente para el desarrollo de la tarea docente. Los profesionales que han participado en el estudio señalan la necesidad de recibir formación y analizar pormenorizadamente estos aspectos.

Entre las limitaciones de este estudio cabe citar por un lado las dificultades de infraestructura referidas fundamentalmente a la conexión a Internet que ha dificultado el desarrollo del curso y a la duración de la capacitación que se ha desarrollado en una sola sesión. En este sentido, casi el 100\% del profesorado del centro señalaban que debería repetirse o al menos prolongarse más. Por otro lado, en cuanto a las limitaciones conceptuales destaca el escaso conocimiento de la mayoría de participantes quienes desconocían, en su mayoría, el término competencia mediática. Una limitación que puede relacionarse de forma directa con los aspectos a mejorar que han citado los participantes que apelaban a la falta de actividades concretas y la profundización en la temática.

Además, han señalado diversas propuestas ante la pregunta: "Qué aspectos mejorarías en el diseño de la actividad formativa", respuestas que apuntan, tanto a la necesidad de recibir formación y clases de carácter práctico donde pueda verse cómo aplicar los contenidos impartidos en el curso, así como al grado de profundización y la continuidad de los temas tratados.

En general, destaca el interés del profesorado por estar formado y por conocer más sobre alfabetización mediática y la necesidad de que se implementen propuestas en esta misma línea. Además de ello, se percibe un cierto desinterés por parte de la administración y el gobierno que, si bien ha dotado de herramientas a los centros educativos convirtiéndolos, como es el caso de la escuela a la que nos hemos referido, en centros TIC, no capacita al profesorado adecuadamente, según las necesidades detectadas. Por ende, iniciativas como la que hemos puesto en marcha, siguiendo el marco de las Recomendaciones sobre alfabetización dictadas por el Parlamento y la Comisión Europea (2009), y teniendo en cuenta que los medios ejercen una notable influencia sobre el receptor (Alvarado, 2012), deberían repetirse y ampliarse. Un deseo que reflejan en sus respuestas los participantes que si 
bien consideran en un $97 \%$ que el uso de las TIC es muy importante, afirman que carecen de las habilidades necesarias para implementarlas en su trabajo como docentes. Una respuesta que avala la baja frecuencia de uso que señalan tener sobre las citadas herramientas y que certifica los resultados que dan respuesta a los objetivos abordados en este estudio.

\section{Apoyos y agradecimientos}

Este trabajo está avalado por el Proyecto I+D+I, titulado "Competencias mediáticas de la ciudadanía en medios digitales emergentes (smartphones y tablets): practicas innovadoras y estrategias educomunicativas en contextos múltiples" con clave EDU2015-64015-C3-1-R (MINECO/FEDER), financiado por el Fondo Europeo de Desarrollo Regional (FEDER) y Ministerio de Economía y Competitividad de España.

\section{Bibliografía}

Aguaded, I. (2014). Desde la infoxicación al derecho a la comunicación [From Infoxication to the Right to Communicate]. Comunicar, 42, 07-08. https:// doi.org/10.3916/C42-2014-a1

Alvarado, J. (2012). Medios de comunicación y política exterior del estado. La prensa y el proceso de paz Ecuador-Perú: 1998. Universitas 16, 69-92. Recuperado de https://goo.gl/XY2DtD

Bauman, Z. (2000). Modernidad líquida. FCE: México http://goo.gl/SsvyKr

Bitar, S. (2011). Formación docente en Chile. CINDE: Chile. Recuperado de https:// goo.gl/gSPr8s

Caldeiro-Pedreira, M. C. \& Aguaded-Gómez, I. (2012). Autonomía mediática en docentes y discentes deeducación secundaria. Contribuciones del Centro de Formación y Recursos de Lugo. Revista Aularia, 1(2), 187-195. Recuperado de http://goo.gl/Ms0wIH

Caldeiro-Pedreira, M. C. \& Aguaded-Gómez, I. (2015). 'Estoy aprendiendo, no me molestes' la competencia mediática como forma de expresión crítica de nativos e inmigrantes digitales. Redes.com, 12. Recuperado de http:// goo.gl/2ORkf1

Celot, P. (Project Coordinator and editor), \& Pérez-Tornero, J. M. (Scientific Coordinator). (2009). Study on Assessment Criteria for Media Literacy Le- 
vels - A comprehensive view of the concept of media literacy and an Understanding of how media literacy level in Europe Should Be Assessed. Brussels: European Commission. Recuperado de http://goo.gl/rnXfa8

DeSeCo (1998). La definición y selección de competencias clave. Recuperado de https://goo.gl/fIi9Pq

Fernández-García, N; Blasco-Duatis, M. \& Caldeiro-Pedreira, M. (2016). Communication and Education by Transmedia. Report on ICT skills in four secondary schools in Europe. Cuadernos Artesanos de Comunicación, 108 - English Version. La Laguna (Tenerife): Latina. Recuperado de http:// goo.gl/f19mrK

Ferrés, J. \& Piscitelli, A. (2012). La competencia mediática: propuesta articulada de dimensiones e indicadores. Comunicar, 38, 75-82. doi.org/10.3916/ C38-2012-02-08

González-Fernández, N.; Salcines-Talledo, I. \& Maraver-López, P. (2016) Spanish parents' perception of family media literacy. Cultura y educación, 28, 468-199. http://dx.doi.org/10.1080/11356405.2016.1196898

INTEF (2017). Marco Común de Competencia Digital Docente. Recuperado de https://goo.gl/OQkj6R

Levis, D. (2006). Alfabetos y saberes: la alfabetización digital [Literates and knowledge: the digital literacy]. Comunicar, 26, 78-82

López, N; Opertti, L. \& Vargas, C. (coord.) (2017). Adolescentes y jóvenes en realidades cambiantes. Notas para repensar la educación secundaria en América Latina. UNESCO: Francia. Recuperado de https://goo.gl/6PPcqC

Ortiz, M.Á. (2008). Educar la mirada en la 'sociedad multipantalla' [To teach the look in a multi-screen society]. Comunicar, 31, 10-13. https://doi. org/10.3916/c31-2008-01-001

Pérez-Tornero, J.M. (2005). El futuro de la sociedad digital y los nuevos valores de la educación en medios [The future of the digital society and values in media education]. Comunicar, 25, 247-258

Pérez-Lisboa, S. \& Caldeiro-Pedreira, M. C (2017). Aula didáctica digital: realidad aumentada y pizarra digital interactiva. Revista Didáctica, Innovación y Multimedia, 35. Recuperado de https://goo.gl/1R5mn4

Quendler, E. \& Lamb, M. (2016). Learning as a lifelong process - meeting the challenges of the changing employability landscape: competences, skills and knowledge for sustainable development. International Journal of Continuing Engineering Education and Life Long Learning, 26(3), 273-293. DOI http://dx.doi.org/10.1504/IJCEELL.2016.078447. 
Ramírez-García, A., Renés-Arellano, P., Aguaded Gómez, J. (2016). La competencia mediática en los criterios de evaluación del currículo de Educación Primaria. Aula Abierta. 44, 2, 55-62, DOI: 10.1016/j.aula.2015.08.002

Sánchez-Carrero, J. y Contreras-Pulido, P. (2012). De cara al prosumidor: Producción y consumo empoderando a la ciudadanía 3.0. Icono 14, 10 (3), 6284. Recuperado de https://goo.gl/ge7Ija

Sandoval, Y.; Manrique, J.; Arenas, A.; Martínez, M. C; Hernández, M. \& Serna, A. (2016). Los jóvenes y la competencia mediática.Valle del Cauca-Colombia. Editorial USC:Colombia

Terceiro, J. (1996). Sociedad digital: del homo sapiens al homo digitalis. Madrid: Alianza eEditorial.

UNESCO (2008). Estándares TIC para la formación inicial docente: una propuesta en el contexto chileno. Chile: Gráfica LOM. Recuperado de https://goo. $\mathrm{gl} / \mathrm{t} 0 \mathrm{HG} 3 \mathrm{G}$

UNESCO (2014). UNESCO Education Strategy 2014-2021. París: UNESCO. Recuperado de: https://goo.gl/Cbr2lg.

UNESCO (2014b). Informe sobre tendencias sociales y educativas en América Latina 2014. Recuperado de https://goo.gl/kPDhct

UNESCO (2016). Tecnología digital al servicio de la calidad educativa. Una propuesta de cambio centrada en el aprendizaje para todos. Unesco Santiago.

White, D. \& Le Cornu, A. (2011). Visitors and Residents: A new typology for online engagement. First Monday, 9(16). Recuperado de http://dx.doi. org/10.5210/fm.v16i9.3171

Fecha de recepción: 20/05/2017; fecha de aceptación: 18/08/2017; fecha de publicación: 01/09/2017 


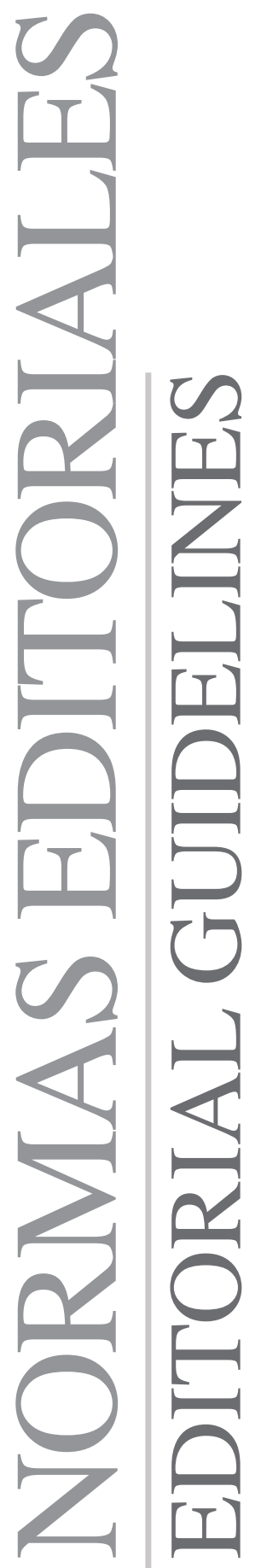





\section{NORMAS DE PUBLICACIÓN EN «UNIVERSITAS»}

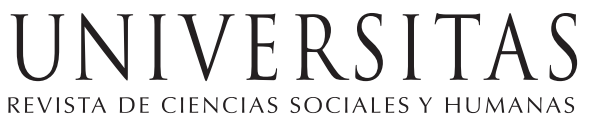

ISSN: 1390-3837 / e-ISSN: 1390-8634

\section{Información general}

«Universitas» es una publicación científica bilingüe de la Universidad Politécnica Salesiana de Ecuador, editada desde enero de 2002 de forma ininterrumpida, con periodicidad fija semestral, especializada en Ciencias Sociales y Humanas y sus líneas interdisciplinares como Sociología, Antropología, Psicología Social, Desarrollo Social, Comunidades, Estudios Latinoamericanos, Estudios Políticos, entre otras.

Es una revista científica arbitrada, que utiliza el sistema de evaluación externa por expertos (peer-review), bajo metodología de pares ciegos (doble-blind review), conforme a las normas de publicación de la American Psychological Association (APA). El cumplimiento de este sistema permite garantizar a los autores un proceso de revisión objetivo, imparcial y transparente, lo que facilita a la publicación su inclusión en bases de datos, repositorios e indexaciones internacionales de referencia.

«Universitas» se encuentra indexada en el directorio y catálogo selectivo del Sistema Regional de Información en Línea para Revistas Científicas de América Latina, el Caribe, España y Portugal (Latindex), en el Sistema de Información Científica REDALYC, en el Directorio de Revistas de Acceso Abierto DOAJ y en repositorios, bibliotecas y catálogos especializados de Iberoamérica.

La revista se edita en doble versión: impresa (ISSN: 1390-3837) y electrónica (e-ISSN: 1390-8634), en español e inglés, siendo identificado además cada trabajo con un DOI (Digital Object Identifier System). 


\section{Alcance y Política}

\subsection{Temática}

Contribuciones originales en materia de Ciencias Humanas y Sociales, así como áreas afines: Sociología, Antropología, Psicología Social, Desarrollo Social, Comunidades, Estudios Latinoamericanos, Estudios Políticos, y todas aquellas disciplinas conexas interdisciplinarmente con la línea temática central.

\subsection{Aportaciones}

«Universitas» edita preferentemente resultados de investigación empírica sobre Ciencias Humanas y Sociales, redactados en español y/o inglés, siendo también admisibles informes, estudios y propuestas, así como selectas revisiones de la literatura (state-of-the-art).

Todos los trabajos deben ser originales, no haber sido publicados en ningún medio ni estar en proceso de arbitraje o publicación. De esta manera, las aportaciones en la revista pueden ser:

- Investigaciones: 5.000 a 6.500 palabras de texto, incluyendo título, resúmenes, descriptores, tablas y referencias.

- Informes, estudios y propuestas: 5.000 a 6.500 palabras de texto, incluyendo título, resúmenes, tablas y referencias.

- Revisiones: 6.000 a 7.000 palabras de texto, incluidas tablas y referencias. Se valorará especialmente las referencias justificadas, actuales y selectivas de alrededor de unas 70 obras.

«Universitas» tiene periodicidad semestral (20 artículos por año), publicada en los meses de marzo y septiembre y cuenta por número con dos secciones de cinco artículos cada una, la primera referida a un tema Monográfico preparado con antelación y con editores temáticos y la segunda, una sección de Misceláneas, compuesta por aportaciones variadas dentro de la temática de la publicación.

\section{Presentación, estructura y envío de los manuscritos}

Los trabajos se presentarán en tipo de letra Arial 10, interlineado simple, justificado completo y sin tabuladores ni espacios en blanco entre párrafos. 
Solo se separarán con un espacio en blanco los grandes bloques (título, autores, resúmenes, descriptores, créditos y epígrafes). La página debe tener 2 centímetros en todos sus márgenes.

Los trabajos deben presentarse en documento de Microsoft Word (.doc o .docx), siendo necesario que el archivo esté anonimizado en Propiedades de Archivo, de forma que no aparezca la identificación de autor/es.

Los manuscritos deben ser enviados única y exclusivamente a través del OJS (Open Journal System), en el cual todos los autores deben darse de alta previamente. No se aceptan originales enviados a través de correo electrónico u otra interfaz.

\subsection{Estructura del manuscrito}

Para aquellos trabajos que se traten de investigaciones de carácter empírico, los manuscritos seguirán la estructura IMRDC, siendo opcionales los epígrafes de Notas y Apoyos. Aquellos trabajos que por el contrario se traten de informes, estudios, propuestas y revisiones podrán ser más flexibles en sus epígrafes, especialmente en Material y métodos, Análisis y resultados y Discusión y conclusiones. En todas las tipologías de trabajos son obligatorias las Referencias.

1) Título (español) / Title (inglés): Conciso pero informativo, en castellano en primera línea y en inglés en segunda. Se aceptan como máximo 80 caracteres con espacio. El título no solo es responsabilidad de los autores, pudiéndose proponer cambios por parte del Consejo Editorial.

2) Nombre y apellidos completos: De cada uno de los autores, organizados por orden de prelación. Se aceptarán como máximo 3 autores por original, aunque pudieren existir excepciones justificadas por el tema, su complejidad y extensión. Junto a los nombres ha de seguir la categoría profesional, centro de trabajo, correo electrónico de cada autor y número de ORCID. Es obligatorio indicar si se posee el grado académico de doctor (incluir Dr./Dra. antes del nombre).

3) Resumen (español) / Abstract (inglés): Tendrá como extensión máxima 230 palabras, primero en español y después en inglés. En el resumen se describirá de forma concisa y en este orden: 1) Justificación del tema; 2) Objetivos; 3) Metodología y muestra; 4) Principales resultados; 5) Principales conclusiones. Ha de estar escrito de manera impersonal "El presente trabajo analiza...". En el caso del abstract no se admitirá el empleo de traductores automáticos por su pésima calidad. 
4) Descriptores (español) / Keywords (inglés): Se deben exponer 6 descriptores por cada versión idiomática relacionados directamente con el tema del trabajo. Será valorado positivamente el uso de las palabras claves expuestas en el Thesaurus de la UNESCO.

5) Introducción y estado de la cuestión: Debe incluir el planteamiento del problema, el contexto de la problemática, la justificación, fundamentos y propósito del estudio, utilizando citas bibliográficas, así como la literatura más significativa y actual del tema a escala nacional e internacional.

6) Material y métodos: Debe ser redactado de forma que el lector pueda comprender con facilidad el desarrollo de la investigación. En su caso, describirá la metodología, la muestra y la forma de muestreo, así como se hará referencia al tipo de análisis estadístico empleado. Si se trata de una metodología original, es necesario exponer las razones que han conducido a su empleo y describir sus posibles limitaciones.

7) Análisis y resultados: Se procurará resaltar las observaciones más importantes, describiéndose, sin hacer juicios de valor, el material y métodos empleados. Aparecerán en una secuencia lógica en el texto y las tablas y figuras imprescindibles evitando la duplicidad de datos.

8) Discusión y conclusiones: Resumirá los hallazgos más importantes, relacionando las propias observaciones con estudios de interés, señalando aportaciones y limitaciones, sin redundar datos ya comentados en otros apartados. Asimismo, el apartado de discusión y conclusiones debe incluir las deducciones y líneas para futuras investigaciones.

9) Apoyos y agradecimientos (opcionales): El Council Science Editors recomienda a los autor/es especificar la fuente de financiación de la investigación. Se considerarán prioritarios los trabajos con aval de proyectos competitivos nacionales e internacionales. En todo caso, para la valoración científica del manuscrito, este debe ir anonimizado con XXXX solo para su evaluación inicial, a fin de no identificar autores y equipos de investigación, que deben ser explicitados en la Carta de Presentación y posteriormente en el manuscrito final.

10) Las notas (opcionales) irán, solo en caso necesario, al final del artículo (antes de las referencias). Deben anotarse manualmente, ya que el sistema de notas al pie o al final de Word no es reconocido por los sistemas de maquetación. Los números de notas se colocan en superíndice, tanto en el texto como en la nota final. No se permiten notas que recojan citas bibliográficas simples (sin comentarios), pues éstas deben ir en las referencias. 
11) Referencias: Las citas bibliográficas deben reseñarse en forma de referencias al texto. Bajo ningún caso deben incluirse referencias no citadas en el texto. Su número debe ser suficiente para contextualizar el marco teórico con criterios de actualidad e importancia. Se presentarán alfabéticamente por el primer apellido del autor.

\subsection{Normas para las referencias}

PUBLICACIONES PERIÓDICAS

Artículo de revista (un autor): Valdés-Pérez, D. (2016). Incidencia de las técnicas de gestión en la mejora de decisiones administrativas [Impact of Management Techniques on the Improvement of Administrative Decisions]. Retos, 12(6), 199-2013. https://doi.org/10.17163/ret.n12.2016.05

Artículo de revista (hasta seis autores): Ospina, M.C., Alvarado, S.V., Fefferman, M., \& Llanos, D. (2016). Introducción del dossier temático "Infancias y juventudes: violencias, conflictos, memorias y procesos de construcción de paz" [Introduction of the thematic dossier "Infancy and Youth: Violence, Conflicts, Memories and Peace Construction Processes"]. Universitas, 25(14), 91-95. https://doi.org/10.17163/uni.n25.\%25x

Artículo de revista (más de seis autores): Smith, S.W., Smith, S.L. Pieper, K.M., Yoo, J.H., Ferrys, A.L., Downs, E.,... Bowden, B. (2006). Altruism on American Television: Examining the Amount of, and Context Surronding. Acts of Helping and Sharing. Journal of Communication, 56(4), 707-727. https://doi.org/10.1111/j.1460-2466.2006.00316.x

Artículo de revista (sin DOI): Rodríguez, A. (2007). Desde la promoción de salud mental hacia la promoción de salud: La concepción de lo comunitario en la implementación de proyectos sociales. Alteridad, 2(1), 28-40. (https://goo.gl/zDb3Me) (2017-01-29).

LIBROS Y CAPÍTULOS DE LIBRO

Libros completos: Cuéllar, J.C., \& Moncada-Paredes, M.C. (2014). El peso de la deuda externa ecuatoriana. Quito: Abya-Yala.

Capítulos de libro: Zambrano-Quiñones, D. (2015). El ecoturismo comunitario en Manglaralto y Colonche. En V.H. Torres (Ed.), Alternativas de Vida: Trece experiencias de desarrollo endógeno en Ecuador (pp. 175-198). Quito: Abya-Yala. 
Medios EleCtrónicos

Pérez-Rodríguez, M.A., Ramírez, A., \& García-Ruíz, R. (2015). La competencia mediática en educación infantil. Análisis del nivel de desarrollo en España. Universitas Psychologica, 14(2), 619-630. https://doi.org.10.11144/ Javeriana.upsy14-2.cmei

Es prescriptivo que todas las citas que cuenten con DOI (Digital Object Identifier System) estén reflejadas en las Referencias (pueden obtenerse en http://goo.gl/gfruh1). Todas las revistas y libros que no tengan DOI deben aparecer con su link (en su versión on-line, en caso de que la tengan, acortada, mediante Google Shortener: http://goo.gl) y fecha de consulta en el formato indicado.

Los artículos de revistas deben ser expuestos en idioma inglés, a excepción de aquellos que se encuentren en español e inglés, caso en el que se expondrá en ambos idiomas utilizando corchetes. Todas las direcciones web que se presenten tienen que ser acortadas en el manuscrito, a excepción de los DOI que deben ir en el formato indicado (https://doi.org/XXX).

\subsection{Epígrafes, tablas y gráficos}

Los epígrafes del cuerpo del artículo se numerarán en arábigo. Irán sin caja completa de mayús-culas, ni subrayados, ni negritas. La numeración ha de ser como máximo de tres niveles: 1./ 1.1./ 1.1.1. Al final de cada epígrafe numerado se establecerá un retorno de carro.

Las tablas deben presentarse incluidas en el texto en formato Word según orden de aparición, numeradas en arábigo y subtituladas con la descripción del contenido.

Los gráficos o figuras se ajustarán al número mínimo necesario y se presentarán incorporadas al texto, según su orden de aparición, numeradas en arábigo y subtituladas con la descripción abreviada. Su calidad no debe ser inferior a 300 ppp, pudiendo ser necesario contar con el gráfico en formato TIFF, PNG o JPEG.

\section{Proceso de envío}

Deben remitirse a través del sistema OJS de la revista dos archivos:

1) Presentación y portada, en la que aparecerá el título en español e inglés, nombres y apellidos de los autores de forma estandarizada con nú- 
mero de ORCID, resumen, abstract, descriptores y keywords y una declaración de que el manuscrito se trata de una aportación original, no enviada ni en proceso de evaluación en otra revista, confirmación de las autorías firmantes, aceptación (si procede) de cambios formales en el manuscrito conforme a las normas y cesión parcial de derechos a la editorial (usar modelo oficial de portada).

2) Manuscrito totalmente anonimizado, conforme a las normas referidas en precedencia.

Todos los autores han de darse de alta, con sus créditos, en la plataforma OJS, si bien uno solo de ellos será el responsable de correspondencia. Ningún autor podrá enviar o tener en revisión dos manuscritos de forma simultánea, estimándose una carencia de cuatro números consecutivos (2 años). 



\section{PUBLICATION GUIDELINES IN «UNIVERSITAS» \\ UNIVERSITAS \\ REVISTA DE CIENCIAS SOCIALES Y HUMANAS}

ISSN: 1390-3837 / e-ISSN: 1390-8634

\section{General Information}

«Universitas» is a bilingual scientific publication of the Universidad Politécnica Salesiana of Ecuador, published since January 2002 in an uninterrupted manner, with a semi-annual periodicity, specialized in Social and Human Sciences and its interdisciplinary lines such as Sociology, Anthropology, Social Psychology, Social Development, Communities, Latin American Studies, Political Studies, among others.

It is scientific journal, which uses the peer-review system, under double-blind review methodology, according to the publication standards of the American Psychological Association (APA). Compliance with this system allows authors to guarantee an objective, impartial and transparent review process, which facilitates the publication of their inclusion in reference databases, repositories and international indexing.

«Universitas» is indexed in the directory and selective catalog of the Regional Online Information System for Scientific Journals of Latin America, the Caribbean, Spain and Portugal (Latindex), in the Scientific Information System REDALYC, in the Directory of Journals of Open Access DOAJ and in repositories, libraries and specialized catalogs of Latin America.

The journal is published in a double version: printed (ISSN: 1390-3837) and digital (e-ISSN: 1390-8634), in English and Spanish, each work being identified with a DOI (Digital Object Identifier System). 


\section{Scope and Policy}

\subsection{Theme}

Original contributions in Humanities and Social Sciences, as well as related areas: Sociology, Anthropology, Social Psychology, Social Development, Communities, Latin American Studies, Political Studies, and all related interdisciplinary disciplines with the central theme.

\subsection{Contributions}

"Universitas" preferably publishes results of empirical research on $\mathrm{Hu}-$ man and Social Sciences, written in Spanish and / or English, as well as reports, studies and proposals, as well as selected state-of-the-art literature reviews.

All works must be original, have not been published in any medium or be in the process of arbitration or publication.

- Research: 5,000 to 6,500 words of text, including title, abstracts, descriptors, charts and references.

- Reports, studies and proposals: 5,000 to 6,500 words of text, including title, abstracts, charts and references.

- Reviews: 6,000 to 7,000 words of text, including charts and references. Justified references, would be specially valued. (current and selected from among 70 works)

"Universitas" has a biannual periodicity (20 articles per year), published in March and September and counts by number with two sections of five articles each, the first referring to a Monographic topic prepared in advance and with thematic editors and the Second, a section of Miscellaneous, composed of varied contributions within the theme of the publication.

\section{Presentation, Structure and Submission of the Manuscripts}

Texts will be presented in Arial 10 font, single line spacing, complete justification and no tabs or white spaces between paragraphs. Only large blocks (title, authors, summaries, descriptors, credits and headings) will 
be separated with a blank space. The page should be 2 centimeters in all its margins.

Papers must be submitted in a Microsoft Word document (.doc or .docx), requiring that the file be anonymized in File Properties, so that the author / $\mathrm{s}$ identification does not appear.

Manuscripts must be submitted only and exclusively through the OJS (Open Journal System), in which all authors must previously register. Originals sent via email or other interfaces are not accepted.

\subsection{Structure of the manuscript}

For those works that are empirical investigations, the manuscripts will follow the IMRDC structure, being optional the Notes and Supports. Those papers that, on the contrary, deal with reports, studies, proposals and reviews may be more flexible in their epigraphs, particularly in material and methods, analysis, results, discussion and conclusions. In all typologies of works, references are mandatory.

1) Title (Spanish) / Title (English): Concise but informative, in Spanish on the first line and in English on the second. A maximum of 80 characters with spaces are accepted. The title is not only the responsibility of the authors, changes being able to be proposed by the Editorial Board.

2) Full name and surnames: Of each of the authors, organized by priority. A maximum of 3 authors will be accepted per original, although there may be exceptions justified by the topic, its complexity and extent. Next to the names must follow the professional category, work center, email of each author and ORCID number. It is mandatory to indicate if you have the academic degree of doctor (include Dr./Dra before the name).

3) Abstract (Spanish) / Abstract (English): It will have a maximum extension of 230 words, first in Spanish and then in English. : 1) Justification of the topic; 2) Objectives; 3) Methodology and sample; 4) Main results; 5) Main conclusions. It must be impersonally written "This paper analyzes ...". In the case of the abstract, the use of automatic translators will not be accepted due to their poor quality.

4) Descriptors (Spanish) / Keywords (English): 6 descriptors must be presented for each language version directly related to the subject of the work. The use of the key words set out in UNESCO's Thesaurus will be positively valued. 
5) Introduction and state of the issue: It should include the problem statement, context of the problem, justification, rationale and purpose of the study, using bibliographical citations, as well as the most significant and current literature on the topic at national and international level .

6) Material and methods: It must be written so that the reader can easily understand the development of the research. If applicable, it will describe the methodology, the sample and the form of sampling, as well as the type of statistical analysis used. If it is an original methodology, it is necessary to explain the reasons that led to its use and to describe its possible limitations.

7) Analysis and results: It will try to highlight the most important observations, describing, without making value judgments, the material and methods used. They will appear in a logical sequence in the text and the essential charts and figures avoiding the duplication of data.

8) Discussion and conclusions: Summarize the most important findings, relating the observations themselves with relevant studies, indicating contributions and limitations, without adding data already mentioned in other sections. Also, the discussion and conclusions section should include the deductions and lines for future research.

9) Supports and acknowledgments (optional): The Council Science Editors recommends the author (s) to specify the source of funding for the research. Priority will be given to projects supported by national and international competitive projects. In any case, for the scientific evaluation of the manuscript, it should be only anonymized with XXXX for its initial evaluation, in order not to identify authors and research teams, which should be explained in the Cover Letter and later in the final manuscript.

10) The notes (optional) will go, only if necessary, at the end of the article (before the references). They must be manually annotated, since the system of footnotes or the end of Word is not recognized by the layout systems. The numbers of notes are placed in superscript, both in the text and in the final note. The numbers of notes are placed in superscript, both in the text and in the final note. No notes are allowed that collect simple bibliographic citations (without comments), as these should go in the references.

11) References: Bibliographical citations should be reviewed in the form of references to the text. Under no circumstances should references not mentioned in the text be included. Their number should be sufficient to 
contextualize the theoretical framework with current and important criteria. They will be presented alphabetically by the first last name of the author.

\subsection{Standards for references}

\section{Periodic Publications}

Journal article (author): Valdés-Pérez, D. (2016). Incidencia de las técnicas de gestión en la mejora de decisiones administrativas [Impact of Management Techniques on the Improvement of Administrative Decisions]. Retos, 12(6), 199-2013. https://doi.org/10.17163/ret.n12.2016.05

Journal Article (Up to six authors): Ospina, M.C., Alvarado, S.V., Fefferman, M., \& Llanos, D. (2016). Introducción del dossier temático "Infancias y juventudes: violencias, conflictos, memorias y procesos de construcción de paz" [Introduction of the thematic dossier "Infancy and Youth: Violence, Conflicts, Memories and Peace Construction Processes"]. Universitas, 25(14), 91-95. https://doi.org/10.17163/uni.n25.\%25x

Journal article (more tan six authors): Smith, S.W., Smith, S.L. Pieper, K.M., Yoo, J.H., Ferrys, A.L., Downs, E.,... Bowden, B. (2006). Altruism on American Television: Examining the Amount of, and Context Surronding. Acts of Helping and Sharing. Journal of Communication, 56(4), 707-727. https://doi.org/10.1111/j.1460-2466.2006.00316.x

Journal article (without DOI): Rodríguez, A. (2007). Desde la promoción de salud mental hacia la promoción de salud: La concepción de lo comunitario en la implementación de proyectos sociales. Alteridad, 2(1), 28-40. (https://goo.gl/zDb3Me) (2017-01-29).

\section{BOOKS AND BOOK CHAPTERS}

Full books: Cuéllar, J.C., \& Moncada-Paredes, M.C. (2014). El peso de la deuda externa ecuatoriana. Quito: Abya-Yala.

Chaprter of book: Zambrano-Quiñones, D. (2015). El ecoturismo comunitario en Manglaralto y Colonche. En V.H. Torres (Ed.), Alternativas de Vida: Trece experiencias de desarrollo endógeno en Ecuador (pp. 175-198). Quito: Abya-Yala. 


\section{Digital MEDia}

Pérez-Rodríguez, M.A., Ramírez, A., \& García-Ruíz, R. (2015). La competencia mediática en educación infantil. Análisis del nivel de desarrollo en España. Universitas Psychologica, 14(2), 619-630. https://doi.org.10.11144/ Javeriana.upsy14-2.cmei

It is prescriptive that all quotations that have DOI (Digital Object Identifier System) are reflected in the References (can be obtained at http://goo. gl/gfruh1). All journals and books that do not have DOI should appear with their link (in their online version, if they have it, shortened by Google Shortened: http://goo.gl) and date of consultation in the format indicated.

Journal articles should be presented in English, except for those in Spanish and English, in which case it will be displayed in both languages using brackets. All web addresses submitted must be shortened in the manuscript, except for the DOI that must be in the indicated format (https://doi.org/XXX).

\subsection{Epigraphs, Figures and Charts}

The epigraphs of the body of the article will be numbered in Arabic. They should go without a full box of capital letters, neither underlined nor bold. The numbering must be a maximum of three levels: 1./ 1.1./ 1.1.1. A carriage return will be established at the end of each numbered epigraph.

The charts must be included in the text in Word format according to order of appearance, numbered in Arabic and subtitled with the description of the content.

The graphics or figures will be adjusted to the minimum number required and will be presented incorporated in the text, according to their order of appearance, numbered in Arabic and subtitled with the abbreviated description. Their quality should not be less than 300 dpi, and it may be necessary to have the graph in TIFF, PNG or JPEG format.

\section{Submission Process}

Two files must be sent through the OJS system of the journal:

1) Presentation and cover, in which the title in Spanish and English will appear, names and surnames of the authors in a standardized form with ORCID number, abstract in both Spanish and English, descriptors and ke- 
ywords and a statement that the manuscript is an Origina lcontribution, not sent or in the process of being evaluated in another journal, confirmation of the signatory authors, acceptance (if applicable) of formal changes in the manuscript according to the rules and partial transfer of rights to the publisher (use official cover model).

2) Manuscript totally anonymized, according to the norms referred in precedence.

All authors must register with their credits on the OJS platform, although only one of them will be responsible for correspondence.

No author can submit or have in review two manuscripts simultaneously, estimating an absence of four consecutive numbers (2 years). 



\section{INDICADORES PARA REVISORES EXTERNOS DE «UNIVERSITAS»}

El Consejo de Revisores Externos de «Universitas» es un órgano colegiado independiente cuyo fin es garantizar la excelencia de esta publicación científica, debido a que la evaluación ciega -basada exclusivamente en la calidad de los contenidos de los manuscritos y realizada por expertos de reconocido prestigio internacional en la materia- es la mejor garantía y, sin duda, el mejor aval para el avance de la ciencia y para preservar en esta cabecera una producción científica original y valiosa.

Para ello, el Consejo de Revisores Externos está conformado por diversos académicos y científicos internacionales especialistas en Ciencias Sociales, esenciales para seleccionar los artículos de mayor impacto e interés para la comunidad científica internacional. Esto permite a su vez que todos los artículos seleccionados para publicar en «Universitas» cuenten con un aval académico e informes objetivables sobre los originales.

Por supuesto, todas las revisiones en «Universitas» emplean el sistema estandarizado internacionalmente de evaluación por pares con «doble ciego» (doble-blind) que garantiza el anonimato de los manuscritos y de los revisores de los mismos. Como medida de transparencia, anualmente se hacen públicos en la web oficial de la revista (www. http://Universitas.ups.edu.ec/) los listados completos de los revisores.

\section{Criterios de aceptación/rechazo de evaluación manuscritos}

El equipo editorial de «Universitas» selecciona del listado de revisores del Consejo de Revisores a aquellos que se estiman más cualificado en la temática del manuscrito. Si bien por parte de la publicación se pide la máxima colaboración de los revisores para agilizar las evaluaciones y los informes sobre cada original, la aceptación de la revisión ha de estar vinculada a:

a. Experticia. La aceptación conlleva necesariamente la posesión de competencias en la temática concreta del artículo a evaluar.

b. Disponibilidad. Revisar un original exige tiempo y conlleva reflexión concienzuda de muchos aspectos. 
c. Conflicto de intereses. En caso de identificación de la autoría del manuscrito (a pesar de su anonimato), excesiva cercanía académica o familiar a sus autores, pertenencia a la misma Universidad, Departamento, Grupo de Investigación, Red Temática, Proyectos de Investigación, publicaciones conjuntas con los autores... o cualquier otro tipo de conexión o conflicto/cercanía profesional; el revisor debe rechazar la invitación del editor para su revisión.

d. Compromiso de confidencialidad. La recepción de un manuscrito para su evaluación exige del Revisor un compromiso expreso de confidencialidad, de manera que éste no puede, durante todo el proceso, ser divulgado a un tercero.

En caso que el revisor no pueda llevar a cabo la actividad por algunos de estos motivos u otros justificables, debe notificarlo al editor por la misma vía que ha recibido la invitación, especificando los motivos de rechazo.

\section{Criterios generales de evaluación de manuscritos}

\section{a) Tema}

La temática que se plantea en el original, además de ser valiosa y relevante para la comunidad científica, ha de ser limitada y especializada en tiempo y espacio, sin llegar al excesivo localismo.

\section{b) Redacción}

La valoración crítica en el informe de revisión ha de estar redactada de forma objetiva, aportando contenido, citas o referencias de interés para argumentar su juicio.

\section{c) Originalidad}

Como criterio de calidad fundamental, un artículo debe ser original, inédito e idóneo. En este sentido, los revisores deben responder a estas tres preguntas en la evaluación:

- ¿Es el artículo suficientemente novedoso e interesante para justificar su publicación? 
- ¿Aporta algo al canon del conocimiento?

- ¿Es relevante la pregunta de investigación?

Una búsqueda rápida de literatura utilizando repositorios tales como Web of Knowledge, Scopus y Google Scholar para ver si la investigación ha sido cubierta previamente puede ser de utilidad.

\section{d) Estructura}

Los manuscritos que se remiten a «Universitas» deben seguir obligatoriamente la estructura IMRyD, excepto aquellos que sean revisiones de la literatura o estudios específicos. En este sentido, los originales han de contener resumen, introducción, metodología, resultados, discusión y conclusión.

- El título, el resumen y las palabras clave han de describir exactamente el contenido del artículo.

- La revisión de la literatura debe resumir el estado de la cuestión de las investigaciones más recientes y adecuadas para el trabajo presentado. Se valorará especialmente con criterios de idoneidad y que las referencias sean a trabajos de alto impacto -especialmente en WoS, Scopus, Scielo, etc. Debe incluir además la explicación general del estudio, su objetivo central y el diseño metodológico seguido.

- En caso de investigaciones, en los materiales y métodos, el autor debe precisar cómo se recopilan los datos, el proceso y los instrumentos usados para responder a las hipótesis, el sistema de validación, y toda la información necesaria para replicar el estudio.

- En los resultados se deben especificar claramente los hallazgos en secuencia lógica. Es importante revisar si las tablas o cuadros presentados son necesarios o, caso contrario, redundantes con el contenido del texto.

- En la discusión se deben interpretar los datos obtenidos a la luz de la revisión de la literatura. Los autores deberán incluir aquí si su artículo apoya o contradice las teorías previas. Las conclusiones resumirán los avances que la investigación plantea en el área del conocimiento científico, las futuras líneas de investigación y las principales dificultades o limitaciones para la realización de la investigación.

- Idioma: Se valorará positivamente si el idioma utilizado facilita la lectura y va en favor de la claridad, sencillez, precisión y transpa- 
rencia del lenguaje científico. El Revisor no debe proceder a corrección, ya sea en español o inglés, sino que informará a los Editores de estos errores gramaticales u ortotipográficos.

- Finalmente, se requiere una profunda revisión de las referencias por si se hubiera omitido alguna obra relevante. Las referencias han de ser precisas, citando en la lógica de la temática a estudiar, sus principales obras así como los documentos que más se asemejen al propio trabajo, así como las últimas investigaciones en el área.

\section{Dimensiones relevantes de valoración}

«Universitas» utiliza una matriz de evaluación de cada original que responde a los criterios editoriales y al cumplimiento de la normativa de la publicación. En este sentido los revisores deberán atender a la valoración cuali-cuantitativa de cada uno de los aspectos propuestos en esta matriz con criterios de objetividad, razonamiento, lógica y experticia.

\begin{tabular}{|l|c|}
\hline \multicolumn{1}{|c|}{ INVESTIGACIONES } & \multicolumn{1}{|c|}{ Ítems valorables } \\
\hline \multicolumn{1}{|c|}{} & P. \\
\hline 01. Título y resumen (claridad y estructura) & $0 / 5$ \\
\hline $\begin{array}{l}\text { 02. Relevancia de la temática } \\
\text { 03. Originalidad del trabajo } \\
\text { 04. Revisión de la literatura }\end{array}$ & $0 / 10$ \\
\hline $\begin{array}{l}\text { 05. Estructura y organización artículo } \\
\text { 06. Capacidad argumental } \\
\text { 07. Redacción }\end{array}$ & $0 / 10$ \\
\hline $\begin{array}{l}\text { 08. Rigor metodológico } \\
\text { 09. Instrumentos de investigación }\end{array}$ & $0 / 10$ \\
\hline $\begin{array}{l}\text { 10. Resultados de investigación } \\
\text { 11. Avances } \\
\text { 12. Discusión } \\
\text { 13. Conclusiones }\end{array}$ & $0 / 10$ \\
\hline $\begin{array}{l}\text { 14. Citaciones (variedad y riqueza) } \\
\text { 15. Referencias }\end{array}$ & $0 / 5$ \\
\hline Total máximo & 50 \\
\hline
\end{tabular}


En caso de tratarse el original de una revisión de la literatura (estado de la cuestión) u otro tipo de estudio (informes, propuestas, experiencias, entre otras), el Consejo Editorial remitirá a los revisores una matriz distinta, comprendiendo las características propias de estructura de este tipo de originales:

\begin{tabular}{|l|c|}
\hline \multicolumn{1}{|c|}{ ESTUDIOS, INFORMES, PROPUESTAS, EXPERIENCIAS } \\
\hline \multicolumn{1}{|c|}{ Ítems valorables } & P. \\
\hline 01. Título y resumen (claridad y estructura) & $0 / 5$ \\
\hline 02. Relevancia de la temática & $0 / 10$ \\
\hline 03. Revisión de la literatura & $0 / 10$ \\
\hline $\begin{array}{l}\text { 04. Estructura y organización artículo } \\
\text { 05. Capacidad argumental y coherencia } \\
\text { 06. Redacción científica }\end{array}$ & $0 / 10$ \\
\hline $\begin{array}{l}\text { 07. Aportaciones originales } \\
\text { 08. Conclusiones }\end{array}$ & $0 / 10$ \\
\hline $\begin{array}{l}\text { 09. Citaciones } \\
\text { 10. Referencias }\end{array}$ & $0 / 5$ \\
\hline Total máximo & 50 \\
\hline
\end{tabular}

\section{Cuestiones éticas}

a) Plagio: Aunque la revista utiliza sistemas de detección de plagio, si el revisor sospechare que un original es una copia sustancial de otra obra, ha de informar de inmediato a los Editores citando la obra anterior con tanto detalle cómo le sea posible.

b) Fraude: Si hay sospecha real o remota de que los resultados en un artículo son falsos o fraudulentos, es necesario informar de ellos a los Editores.

\section{Evaluación de los originales}

Una vez realizada la evaluación cuanti-cualitativa del manuscrito en revisión, el revisor podrá realizar recomendaciones para mejorar la calidad 
del original. Sin embargo, se atenderá a la calificación del manuscrito de tres maneras:

a. Rechazo debido a las deficiencias detectadas, justificadas y razonadas con valoración cualitativa y cuantitativa. El informe ha de ser más extenso si obtiene menos de los 30 de los 50 puntos posibles.

b. Aceptación sin revisión.

c. Aceptación condicionada y por ende con revisión (mayor o menor). En este último caso, se ha de identificar claramente qué revisión es necesaria, enumerando los comentarios e incluso especificando párrafos y páginas en las que sugieren modificaciones. 


\section{GUIDELINES FOR EXTERNAL REVIEWERS OF «UNIVERSITAS»}

The Council of External Reviewers of «Universitas» is an independent collegiate body whose purpose is to guarantee the excellence of this scientific publication, because the blind evaluation - based exclusively on the quality of the contents of the manuscripts and carried out by experts of recognized International prestige in the field - is, without a doubt, the best guarantee for the advancement of science and to preserve in this header an original and valuable scientific production.

To this end, the Council of External Reviewers is made up of several scholars and international scientists specialized in Education, essential to select the articles of the greatest impact and interest for the international scientific community. This in turn allows that all the articles selected to publish in «Universitas» have an academic endorsement and objectifiable reports on the originals.

Of course, all reviews in «Universitas» use the internationally standardized system of double-blind peer evaluation that guarantees the anonymity of manuscripts and reviewers. As a measure of transparency, the complete lists of reviewers are published on the official website of the journal (www. http://Universitas.ups.edu.ec/) los listados completos de los revisores.

\section{Criteria for acceptance/rejection of manuscript evaluation}

The editorial team of «Universitas» selects those that are considered more qualified in the subject of the manuscript from the list of reviewers of the Council of Reviewers. While the publication requires the maximum collaboration of reviewers to expedite the evaluations and reports on each original, acceptance of the review must be linked to:

a. Expertise. Acceptance necessarily entails the possession of competences in the specific theme of the article to be evaluated.

b. Availability. Reviewing an original takes time and involves careful reflection on many aspects. 
c. Conflict of interests. In case of identification of the authorship of the manuscript (despite their anonymity), excessive academic or family closeness to their authors, membership in the same University, Department, Research Group, Thematic Network, Research Projects, joint publications with authors ... or any other type of connection or conflict / professional proximity; The reviewer must reject the publisher's invitation for review.

d. Commitment of confidentiality. Reception of a manuscript for evaluation requires the Reviewer to express a commitment of confidentiality, so that it cannot be divulged to a third party throughout the process.

In the event that the reviewer cannot carry out the activity for some of these reasons or other justifiable reasons, he/she must notify the publisher by the same route that he/she has received the invitation, specifying the reasons for rejection.

\section{General criteria for the evaluation of manuscripts}

\section{a) Topic}

In addition to being valuable and relevant to the scientific community, the topic that is presented in the original must be limited and specialized in time and space, without excessive localism.

\section{b) Redaction}

The critical assessment in the review report must be objectively written, providing content, quotes or references of interest to support its judgment.

\section{c) Originality}

As a fundamental criterion of quality, an article must be original, unpublished and suitable. In this sense, reviewers should answer these three questions in the evaluation:

- Is the article sufficiently novel and interesting to justify publication?

- Does it contribute anything to the knowledge canon? 
- Is the research question relevant?

A quick literature search using repositories such as Web of Knowledge, Scopus and Google Scholar to see if the research has been previously covered, may be helpful.

\section{d) Structure}

Manuscripts that refer to «Universitas» must follow the IMRDC structure, except those that are literature reviews or specific studies. In this sense, the originals must contain summary, introduction, methodology, results, discussion and conclusion.

- The title, abstract, and keywords should accurately describe the content of the article.

- The review of the literature should summarize the state of the question of the most recent and adequate research for the presented work. It will be especially evaluated with criteria of suitability and that the references are to works of high impact - especially in WoS, Scopus, Scielo, etc. It should also include the general explanation of the study, its central objective and the followed methodological design.

- In case of research, in the materials and methods, the author must specify how the data, the process and the instruments used to respond to the hypothesis, the validation system, and all the information necessary to replicate the study are collected.

- Results must be clearly specified in logical sequence. It is important to check if the figures or charts presented are necessary or, if not, redundant with the content of the text.

- In the discussion, the data obtained should be interpreted in the light of the literature review. Authors should include here if their article supports or contradicts previous theories. The conclusions will summarize the advances that the research presents in the area of scientific knowledge, the future lines of research and the main difficulties or limitations for carrying out the research.

- Language: It will be positively assessed if the language used facilitates reading and is in favor of the clarity, simplicity, precision and transparency of the scientific language. The Reviewer should not proceed to correction, either in Spanish or English, but will inform 
the Editors of these grammatical or orthographical and typographical errors.

- Finally, a thorough review of the references is required in case any relevant work has been omitted. The references must be precise, citing within the logic of the subject at study, its main works as well as the documents that most resemble the work itself, as well as the latest research in the area.

\section{Relevant valuation dimensions}

«Universitas» uses an evaluation matrix of each original that responds to the editorial criteria and to compliance with the publication normative. In this sense, the reviewers must attend to the qualitative-quantitative assessment of each of the aspects proposed in this matrix with criteria of objectivity, reasoning, logic and expertise.

\begin{tabular}{|l|c|}
\hline \multicolumn{1}{|c|}{ RESEARCHES } \\
\hline \multicolumn{1}{|c|}{ Valuable items } & P. \\
\hline 01. Title and abstract (clarity and structure) & $0 / 5$ \\
\hline $\begin{array}{l}\text { 02. Thematic relevance } \\
\text { 03. Originality of the work } \\
\text { 04. Review of the literature }\end{array}$ & $0 / 10$ \\
\hline $\begin{array}{l}\text { 05. Structure and organization of the article } \\
\text { 06. Argumentative capabilities } \\
\text { 07. Redaction }\end{array}$ & $0 / 10$ \\
\hline $\begin{array}{l}\text { 08. Methodological rigor } \\
\text { 09. Research instruments }\end{array}$ & $0 / 10$ \\
\hline $\begin{array}{l}\text { 10. Research results } \\
\text { 11. Advances } \\
\text { 12. Discussion } \\
\text { 13. Conclusions }\end{array}$ & $0 / 10$ \\
\hline $\begin{array}{l}\text { 14. Quotations (variety and richness) } \\
\text { 15. References }\end{array}$ & $0 / 5$ \\
\hline Total & 50 \\
\hline
\end{tabular}


If the original is a review of the literature (status of the subject) or other type of study (reports, proposals, experiences, among others), the Editorial Board will send to the reviewers a different matrix, including the characteristics of Structure of this type of originals:

\begin{tabular}{|l|c|}
\hline \multicolumn{2}{|c|}{ REPORTS, STUDIES, PROPOSALS, REVIEWS } \\
\hline \multicolumn{1}{|c|}{ Valuable items } & P. \\
\hline 01. Title and abstract (clarity and structure) & $0 / 5$ \\
\hline 02. Thematic relevance & $0 / 10$ \\
\hline 03. Review of the literature & $0 / 10$ \\
\hline $\begin{array}{l}\text { 04. Structure and organization of the article } \\
\text { 05. Argumentative capabilities and coherence } \\
\text { 06. Scientific redaction }\end{array}$ & $0 / 10$ \\
\hline $\begin{array}{l}\text { 07. original contributions } \\
\text { 08. Conclusions }\end{array}$ & $0 / 10$ \\
\hline $\begin{array}{l}\text { 09. Quotations } \\
\text { 10. References }\end{array}$ & $0 / 5$ \\
\hline Total & 50 \\
\hline
\end{tabular}

\section{Ethical Considerations}

a) Plagiarism: Although the journal uses plagiarism detection systems, if the reviewer suspects that an original is a substantial copy of another work, he must immediately inform the Editors citing the previous work in as much detail as possible.

b) Fraud: If there is real or remote suspicion that the results in an article are false or fraudulent, it is necessary to inform them to the Editors.

\section{Evaluation of the originals}

After the quantitative-qualitative evaluation of the manuscript under review, the reviewer may make recommendations to improve the quality of the manuscript. However, the manuscript will be graded in three ways: 
a. Acceptance without review

b. Conditional acceptance and therefore review (greater or lesser). In the latter case, it is necessary to clearly identify which review is necessary, listing the comments and even specifying paragraphs and pages suggesting modifications.

c. Rejection due to detected deficiencies justified and reasoned with quantitative and quantitative assessment. The report should be longer if a score of less than 40 of the 50 possible points is obtained. 


\section{PROTOCOLO DE EVALUACIÓN DE MANUSCRITOS PARA REVISORES EXTERNOS}

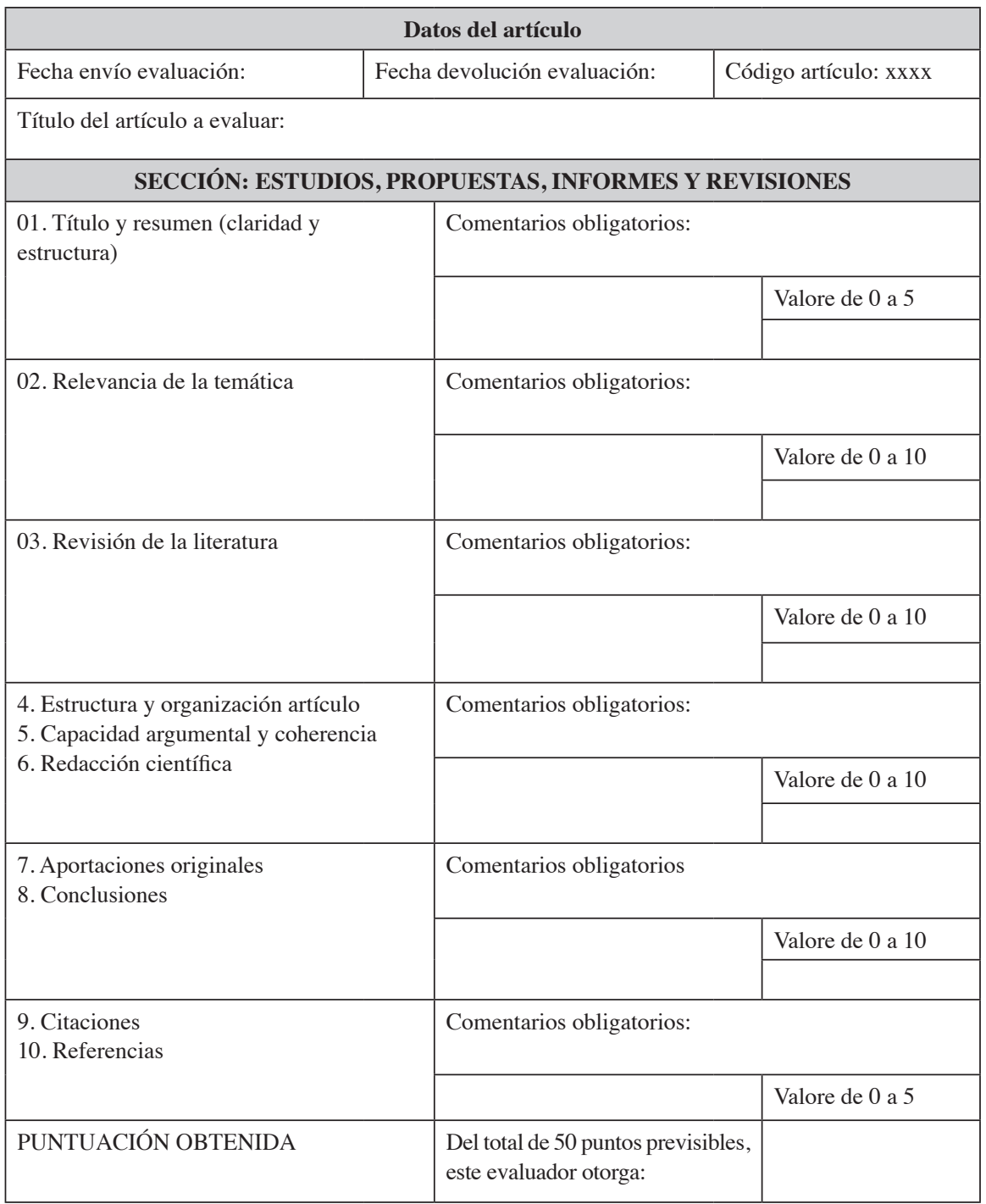




\begin{tabular}{|l|l|l|l|l|}
\hline OPINIÓN & \multicolumn{5}{|l|}{} \\
REDACTADA \\
(Más detallada si el \\
trabajo no obtiene 40 \\
puntos, para informar al \\
autor/es). \\
Este texto se remite \\
textualmente a los autor/es \\
de forma anónima.
\end{tabular}




\section{PROTOCOL OF MANUSCRIPT EVALUATION FOR EXTERNAL REVIEWERS}

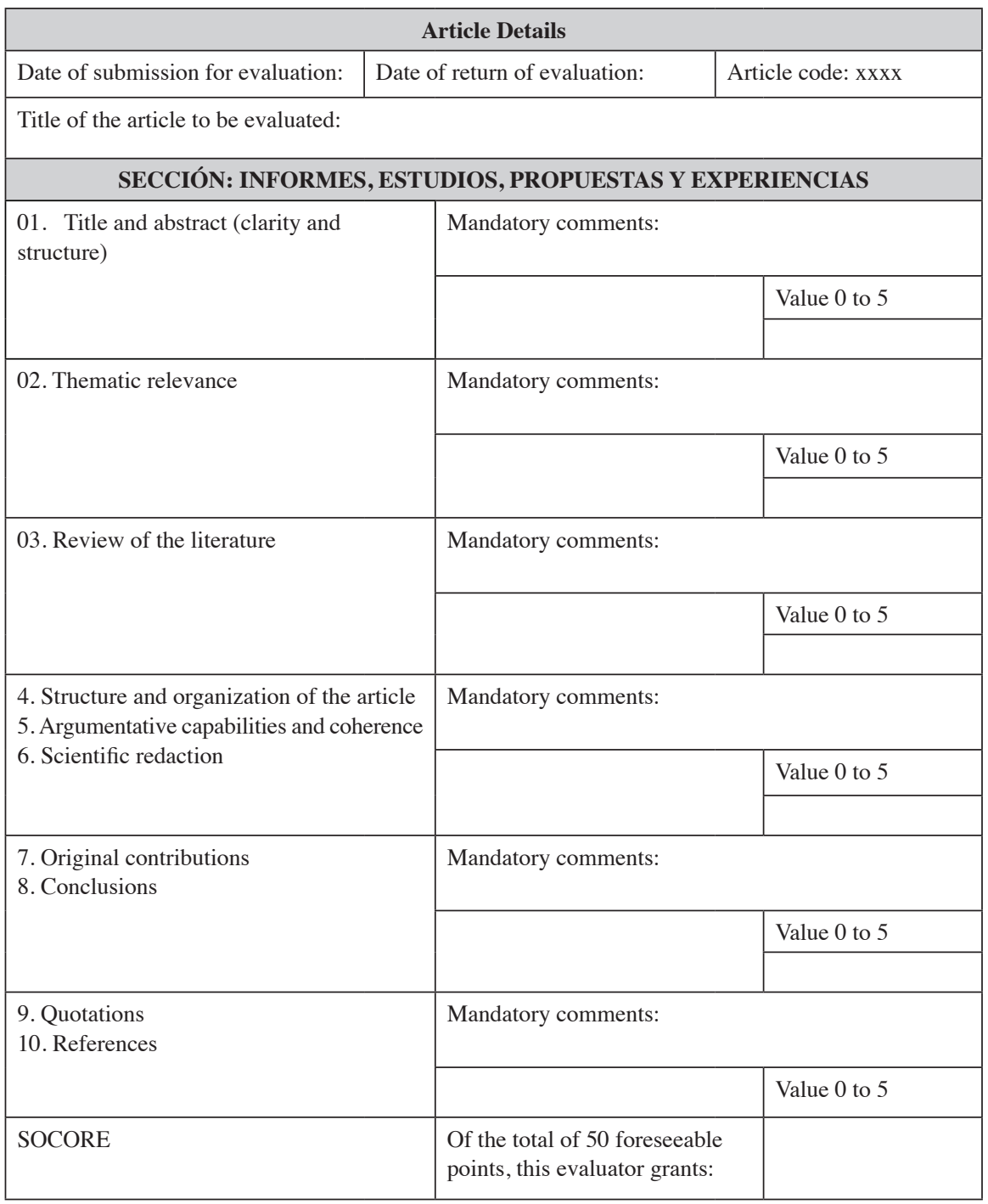




\begin{tabular}{|c|c|c|c|}
\hline $\begin{array}{l}\text { REDACTED OPINION } \\
\text { (More detailed if the work } \\
\text { does not get } 40 \text { points, to } \\
\text { inform the author(s) } \\
\text { This text is sent verbatim } \\
\text { to the author (s) } \\
\text { anonymously. }\end{array}$ & & & \\
\hline WORTH PUBLISHING & No & Yes & $\begin{array}{l}\text { Yes, with minor } \\
\text { changes }\end{array}$ \\
\hline $\begin{array}{l}\text { PROPOSED CHANGES } \\
\text { (In case of "Yes, with } \\
\text { conditions") }\end{array}$ & & & \\
\hline
\end{tabular}




\title{
Cover Letter
}

Sección (Marcar)

Dossier Monográfico

Miscelánea

\section{Título en español: Arial 14 negrita y centrado. Máximo 80 caracteres con espacios}

\author{
Title in English: Arial 14 cursiva. \\ Máximo 80 caracteres con espacios
}

Nombre autor 1 (estandarizado)

Categoría profesional, Institución, País

Correo electrónico institucional

ORCID

Nombre autor 2 (estandarizado)

Categoría profesional, Institución, País

Correo electrónico institucional

ORCID

Nombre autor 3 (estandarizado)

Categoría profesional, Institución, País

Correo electrónico institucional

ORCID

\section{Resumen}

Mínimo 210 y máximo 230 palabras. Debe incluir 1) Justificación del tema; 2) Objetivos; 3) Metodología y muestra; 4) Principales resultados; 5) Principales conclusiones. Ha de estar escrito de manera impersonal "El presente trabajo analiza..." 


\begin{abstract}
Mínimo 210 y máximo 230 palabras cursiva. Debe incluir 1) Justificación del tema; 2) Objetivos; 3) Metodología y muestra; 4) Principales resultados; 5) Principales conclusiones. Ha de estar escrito de manera impersonal “El presente trabajo analiza..." No utilizar sistemas de traducción automáticos.
\end{abstract}

\title{
Descriptores
}

6 términos estandarizados preferiblemente de una sola palabra y del Thesaurus de la UNESCO separados por coma (,).

\section{Kwyword}

Los 6 términos referidos en inglés separados por coma (,). No utilizar sistemas de traducción automáticos.

\section{Apoyos y soporte financiero de la investigación (Opcional)}

Entidad:

País:

Ciudad:

Proyecto subvencionado:

Código de proyecto: 


\section{PRESENTACIÓN}

\section{Cover Letter}

Sr. Editor de «Universitas»

Leída la normativa de la revista «Universitas» y analizada su cobertura, área temática y enfoque, considero que esta revista es la idónea para la difusión del trabajo que le adjunto, por lo que le ruego sea sometida a la consideración para su publicación. El original lleva por título “ ", cuya autoría corresponde a

El autor/es certifican que este trabajo no ha sido publicado, ni está en vías de consideración para su publicación en ninguna otra revista u obra editorial.

El autor/es se responsabilizan de su contenido y de haber contribuido a la concepción, diseño y realización del trabajo, análisis e interpretación de datos, y de haber participado en la redacción del texto y sus revisiones, así como en la aprobación de la versión que finalmente se remite en adjunto.

Se aceptan la introducción de cambios en el contenido si hubiere lugar tras la revisión, y de cambios en el estilo del manuscrito por parte de la redacción de «Universitas».

\section{Cesión de derechos y declaración de conflicto de intereses}

La editorial Abya-Yala (editorial matriz de las obras de la Universidad Politécnica Salesiana de Ecuador) conserva los derechos patrimoniales (copyright) de las obras publicadas y favorecerá la reutilización de las mismas. Las obras se publican en la edición electrónica de la revista bajo una licencia Creative Commons Reconocimiento / No Comercial-Sin Obra Derivada 3.0 Ecuador: se pueden copiar, usar, difundir, transmitir y exponer públicamente.

El autor/es abajo firmante transfiere parcialmente los derechos de propiedad (copyright) del presente trabajo a la editorial Abya-Yala (Ecuador) (RUC: XXXXXX), para las ediciones impresas. 
Se declara además haber respetado los principios éticos de investigación y estar libre de cualquier conflicto de intereses.

En (ciudad), a los días del mes de de 201

Firmado. (Por el autor o en su caso, todos los autores)

Nombre y apellido de los autores

Documento de Identidad

Firma

Nombre y apellido de los autores

Documento de Identidad

Firma

Nombre y apellido de los autores

Documento de Identidad

\section{Firma}

Nota: Una vez haya guardado el documento cumplimentado y firmado, deberá consignarlo a través del sistema OJS en la sección "Ficheros Complementarios". 


\title{
Cover Letter
}

Section (Mark)

Mnographic Dossier

Miscellany

\section{Title in Spanish: Arial 14 bold and centered. Maximum 80 characters with spaces}

\author{
Title in English: Arial 14 cursive. \\ Maximum 80 characters with spaces
}

\begin{abstract}
Name author 1 (standardized)
Professional category, Institution,

Country Institutional email

ORCID
\end{abstract}

Name author 2 (standardized)

Professional category, Institution, Country

Institutional email

ORCID

Name author 3 (standardized)

Professional category, Institution, Country

Institutional email

ORCID

\footnotetext{
Abstract (Spanish)

Minimum 210 and maximum 230 words. It must include 1) Justification of the topic; 2) Objectives; 3) Methodology and sample; 4) Main results; 5) Main conclusions. It must be impersonally written "The present paper analyzes ...”
} 


\section{Abstract (English)}

Minimum 210 and maximum 230 words. It must include 1) Justification of the topic; 2) Objectives; 3) Methodology and sample; 4) Main results; 5) Main conclusions. It must be impersonally written "The present paper analyzes ..." Do not use automatic translation systems.

\section{Descriptors (Spanish)}

6 standardized terms preferably of a single word and of the UNESCO Thesaurus separated by commas (,).

\section{Keywords}

The 6 terms referred to in English separated by commas (,). Do not use automatic translation systems.

\section{Financial Support of Research (Optional)}

Entity:

Country:

City:

Subsidized project:

Code of the project: 


\section{PRESENTATION}

\section{Cover Letter}

Mr. Editor of «Universitas»

Having read the regulations of the journal «Universitas» and analyzed its coverage, thematic area and approach, I consider that this journal is the ideal one for the dissemination of the work that I hereby attach, for which I beg you to be submitted for consideration for publication. The original has the following title " ", whose authorship corresponds to

The authors (s) certify that this work has not been published, nor is it under consideration for publication in any other journal or editorial work.

The author (s) are responsible for their content and have contributed to the conception, design and completion of the work, analysis and interpretation of data, and to have participated in the writing of the text and its revisions, as well as in the approval of the version which is finally referred to as an attachment.

Changes to the content are accepted if they occur after the review process, and also changes in the style of the manuscript by the editorial process of «Universitas».

\section{Transfer of Copyright and Declaration of Conflict of Interest}

The Universidad Politécnica Salesiana of Ecuador preserves the copyrights of the published works and will favor the reuse of the same. The works are published in the electronic edition of the journal under a Creative Commons Attribution / Noncommercial-No Derivative Works 3.0 Ecuador license: they can be copied, used, disseminated, transmitted and publicly displayed.

The undersigned author partially transfers the copyrights of this work to the Universidad Politécnica Salesiana of Ecuador, for the printed editions.

It is also declared that they have respected the ethical principles of research and are free from any conflict of interest. 
In ___ (city), by the days of the month of of 201_

Signed. (By the author or in the case, all the authors)

Authors' first and last name

Identification document

Signature

Authors' first and last name

Identification document

Signature

Authors' first and last name

Identification document

Signature

Note: Once saved the completed and signed document, it must be register through the OJS system in the section "Complementary Files". 


\title{
Convocatoria del dossier "Problemáticas, prácticas y sujetos educativos en América Latina: balances y perspectivas a futuro en tiempos de cambio"
}

\section{Coordinadores del Dossier}

\author{
Dra. Marina Larrondo, (IDES - CONICET, Argentina) \\ Dra. Liliana Mayer (UNAM - CONICET, Argentina) \\ Dra. Pedro Núñez (FLACSO - CONICET/UBA, Argentina) \\ Mg. Sebastián Granda (UPS, Ecuador)
}

\section{Convocatoria}

Desde sus inicios, las ciencias sociales mostraron su interés por la realidad educativa, reflexionando respecto de sus recursos, normas, agentes, instituciones y las prácticas que allí tienen lugar. Más allá de este interés fundacional, los últimos años fueron testigo de la diversificación del campo educativo, cobrando fuerza nuevos objetos de estudio y ampliando los ya existentes, también, a través de disciplinas y puntos de vista diversos.

De manera concomitante, la ampliación de la obligatoriedad y cobertura educativa también colaboraron en la determinación de nuevos ejes al identificar los cambios en los sistemas y políticas educativas. En efecto, los últimos veinte años en la región registraron modificaciones en las legislaciones educativas en casi todos sus países, que fueron determinantes en estos procesos, al mismo tiempo que el ideario del Estado Nación agenciado por los propios sistemas educativas entró muchas veces en crisis. En este sentido, podemos mencionar en particular los procesos de diferenciación socioeconómica expresados principalmente en la privatización creciente de la educación básica u obligatoria, tensionando el ideal de igualdad que pretende por un lado la escuela en su formación ciudadana frente a proyectos que producen simultáneamente fisuras y fragmentaciones en tal proyecto unitario. Estas fragmentaciones no han tenido solamente efectos en la segregación socioeconómica inicial, sino también en términos pedagógicos. Así, los procesos de ampliación de derechos que ocuparon un lugar principal en la agenda educativa de la región, muchas veces impulsados por los "gobiernos progresistas", otras por organismos internacionales, reconocen el lugar 
central de la institución escolar en la aspiración a la constitución de sociedades equitativas -sino igualitarias- e incorporan referencias a la convivencia, la paz, los derechos sexuales y reproductivos o la educación intercultural bilingüe -por mencionar sólo algunos- se enfrentan y conviven con la conformación de espacios escolares que muchas veces tienden a expresar o reflejar diferenciaciones socioeconómicas o su pretensión de distinción social, incidiendo en la generación y ampliación de la desigualdad social y o fragmentaciones culturales. Asimismo, la vocación de ampliar saberes legítimos y prácticas (por ejemplo, el derecho a participar y reconocer la voz de los estudiantes) ha encontrado resistencias en la práctica cotidiana así como muestra las dificultades para que los enunciados legislativos y el diseño de las políticas públicas se plasmen en las instituciones. Estos procesos que inicialmente fueron analizados por los cientistas sociales como propios de la educación secundaria o media, se extendieron al resto de los niveles, mostrando nuevas formas de producción y reproducción de las desigualdades sociales y con ellas, de habitar las instituciones en términos de trayectorias e itinerarios educativos.

La fecha límite para el envío de artículos a través del OJS de la revista es el 10 de noviembre de 2017:. http://revistas.ups.edu.ec/pdf/docs/ universitas/NORMATIVAUNIVERSITAS.pdf 


\section{Call for the dossier "Problems, practices and educational subjects in Latin America: balances and future perspectives in times of change"}

\section{Dossier Coordinators}

Dra. Marina Larrondo, (IDES - CONICET, Argentina)

Dra. Liliana Mayer (UNAM - CONICET, Argentina)

Dra. Pedro Núñez (FLACSO - CONICET/UBA, Argentina)

Mg. Sebastián Granda (UPS, Ecuador)

\section{Theoretical basis}

From its beginnings, the social sciences showed their interest in the educational reality, reflecting on their resources, norms, agents, institutions and the practices that take place there. Beyond this foundational interest, the last years witnessed the diversification of the educational field, gaining strength new objects of study and expanding existing ones, also, through diverse disciplines and points of view. At the same time, the expansion of compulsory education coverage also helped to identify new axes in identifying changes in education systems and policies. In fact, the last twenty years the region registered changes in educational legislation in almost all of its countries, which were decisive in these processes, at the same time as the ideology of the Nation State, which was brokered by the educational systems themselves, often went into crisis. In this sense, we can mention in particular the processes of socioeconomic differentiation expressed mainly in the increasing privatization of basic or compulsory education, stressing the ideal of equality that seeks on the one hand the school in its citizenship formation against projects that simultaneously produce fissures and fragmentations in such a unitary project. These fragmentations have not only had an effect on the initial socioeconomic segregation, but also on pedagogical terms. Thus, the processes of extending rights that have occupied a major place in the educational agenda of the region, often driven by "progressive governments", others by international organizations, recognize the central place of the school institution in the aspiration to the constitution equita- 
ble societies - and incorporate references to coexistence, peace, sexual and reproductive rights or intercultural bilingual education - to mention only a few - face and coexist with the conformation of school spaces that often tend to express or reflect socioeconomic differentiations or their claim to social distinction, affecting the generation and expansion of social inequality and cultural fragmentation. Likewise, the vocation to extend legitimate and practical knowledge (for example, the right to participate and to recognize the voice of students) has found resistance in daily practice as well as shown the difficulties for legislative statements and the design of public policies to be reflected in the institutions. These processes that were initially analyzed by social scientists as belonging to secondary or secondary education, extended to the other levels, showing new forms of production and reproduction of social inequalities and with them, to inhabit institutions in terms of trajectories and educational itineraries.

The deadline for sending articles through the OJS of the journal is November 10, 2017. It appends the publication rules: http://revistas.ups. edu.ec/pdf/docs/universitas/NORMATIVAUNIVERSITAS. pdf 